Editora Poisson

\title{
Processos Químicos e Biotecnológicos Volume 4
}

\author{
1a Edição
}

Belo Horizonte

Poisson

2020 


\section{Editor Chefe: Dr. Darly Fernando Andrade}

\section{Conselho Editorial}

Dr. Antônio Artur de Souza - Universidade Federal de Minas Gerais

Msc. Davilson Eduardo Andrade

Dra. Elizângela de Jesus Oliveira - Universidade Federal do Amazonas

Msc. Fabiane dos Santos

Dr. José Eduardo Ferreira Lopes - Universidade Federal de Uberlândia

Dr. Otaviano Francisco Neves - Pontifícia Universidade Católica de Minas Gerais

Dr. Luiz Cláudio de Lima - Universidade FUMEC

Dr. Nelson Ferreira Filho - Faculdades Kennedy

Ms. Valdiney Alves de Oliveira - Universidade Federal de Uberlândia

Dados Internacionais de Catalogação na Publicação (CIP)

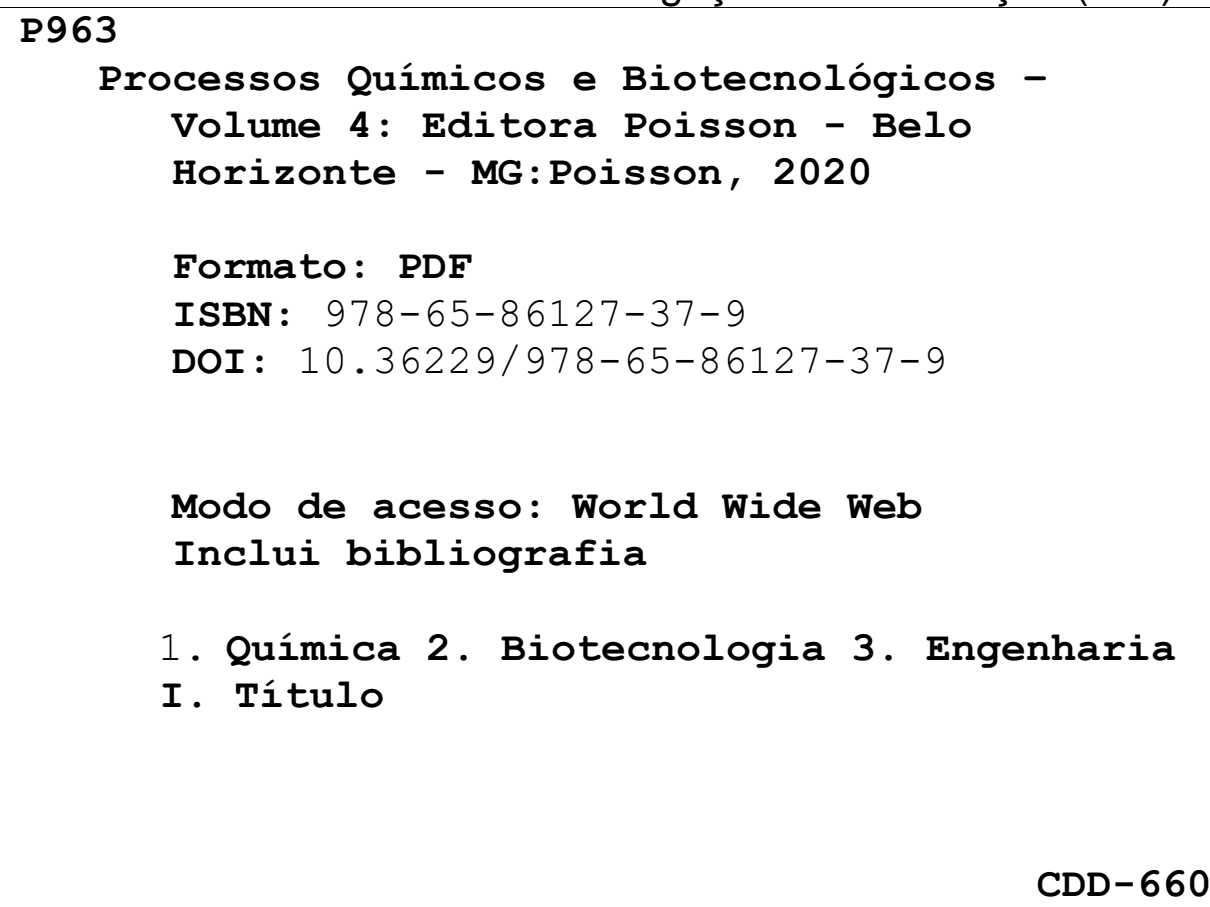

1. Química 2. Biotecnologia 3. Engenharia

I. Título

CDD- 660

O conteúdo dos artigos e seus dados em sua forma, correção e confiabilidade são de responsabilidade exclusiva dos seus respectivos autores

Www.poisson.com.br

contato@poisson.com.br 


\section{SUMÁRIO}

Capítulo 1: Estudo físico-químico de sucos de limão em pó comercializados em Belém do Pará. 07

Jackeline Kerlice Mata Gonçalves, João Pedro dos Reis Lima, Ewerton Carvalho de Souza, Ivan Carlos da Costa Barbosa, Elio Ferreira de Moraes Junior, Allyson Allennon Pinheiro do Rosário, Charles Alberto Brito Negrão, Antonio dos Santos Silva, Ewerton Reginaldo dos Santos Neves

DOI: 10.36229/978-65-86127-37-9.CAP.01

Capítulo 2: Caracterização fisico-química, determinação de compostos bioativos e capacidade antioxidante em garrafada de espinheira santa (Maytenus ilicifolia) ........ 13

Endril Pablo Brasil de Freitas, Rayana Silva Craveiro, João Marcos Batista de Assunção, Yasmin Martins dos Santos Lopes, Alan Moura Feio, Denison Barros Soares, Mayara Martins Galvão, Denilson Barreto da Luz, Elivaldo Nunes Modesto Junior

DOI: $10.36229 / 978-65-86127-37-9 . C A P .02$

Capítulo 3: Quantificação de carbamatos por Extração QuEChERS e CLAE em melancia, Cultivar Crimson Sweet, comercializada em Boa Vista - RR. 19

Maria Janes de Oliveira Santos

DOI: $10.36229 / 978-65-86127-37-9 . C A P .03$

Capítulo 4: Sedimentação contínua do polvilho doce na presença de coagulante a base de moringa oleifera lam 25

Amarílis Severino e Souza, Kássia Graciele dos Santos

DOI: $10.36229 / 978-65-86127-37-9 . C A P .04$

Capítulo 5: Desenvolvimento de um Modelo Matemático para determinação do calor específico de soluções de leite/sacarose em função da temperatura e da concentração 46

Rodrigo Rodrigues Evangelista, Maria Júlia Neves Martins, Thais Siqueira Tomasello, Walisson Guilhermitte Rodrigues, Gisandro Reis de Carvalho, Javier Telis Romero

DOI: $10.36229 / 978-65-86127-37-9 . C A P .05$

Capítulo 6: Densidade e condutividade térmica de soluções de leite/sacarose em função da temperatura e teor de sólidos totais.

Marcio Augusto Ribeiro Sanches, Bianca Guimarães, Walisson Guilhermitte Rodrigues, Thais Siqueira Tomasello, Tiago Carregari Polachini, Javier Telis Romero

DOI: $10.36229 / 978-65-86127-37-9 . C A P .06$ 


\section{SUMÁRIO}

Capítulo 7: Fluidodinâmica da mistura de bagaço de malte e areia em leito de jorro visando a pirólise de biomassa 60

Natália Pazin de Almeida, Beatriz Cristina Silvério, José Luiz Vieira Neto, Felipe Santos Pimentel, Taisa Lira Shimosakai, Kássia Graciele dos Santos

DOI: $10.36229 / 978-65-86127-37-9 . C A P .07$

Capítulo 8: Avaliação da acumulação de metais em plantas medicinais da Vila do Elesbão / Santana - AP.

Hina da Silva Furtado, Alexandro Cezar Florentino, Irlon Ferreira Maciel, Josivan da Silva Costa, Roberto Messias Bezerra

DOI: $10.36229 / 978-65-86127-37-9 . C A P .08$

Capítulo 9: Composito polimérico de fibra de coco: Análise de tração e mecanismos de falha 78

Gilmar Alves Borges, Anderson Mathias Pereira, Emerson Cardoso Rodrigues, Nélio Teixeira Machado, Douglas Alberto Rocha de Castro, Lauro Henrique Hamoy Guerreiro, Romero Moreira de Oliveira, Wenderson Gomes dos Santos

DOI: 10.36229/978-65-86127-37-9.CAP.09

Capítulo 10: Estudo da influência da sedimentação gravitacional da lama vermelha na resistência à chamas de Compósitos Poliméricos 82

Haianny Beatriz Saraiva Lima, Bruno Henrique Alves Mendes, Julianne Silva Lalor, Karla Suellen Lino Barbosa, Wassim Raja El Banna, Deibson Silva da Costa

DOI: $10.36229 / 978-65-86127-37-9 . C A P .10$

Capítulo 11: Artesanato da Amazônia: Viabilidade da utilização de rejeito da Indústria de Cerâmica Vermelha para a produção de utilitários no Polo Artesanal de Icoaraci, Bélem - PA. 87

Gabriel da Silva Gomes, Dayana Rosy Souza dos Santos, Daniel José Lima de Sousa, Dorivane Cohen Farias, Maycon Ruan Pinheiro de Oliveira, Silvio Bispo do Vale, Yuri Ribeiro de Ribeiro, Wilson Guimarães Saraiva, Reginaldo Saboia de Paiva

DOI: $10.36229 / 978-65-86127-37-9 . C A P .11$

Capítulo 12: Obtenção de ésteres etílicos a partir do óleo de tucumã (Astrocaryum Vulgare, Mart.).

Gustavo Henrique Barroso da Silva, Raissa Sayumy Kataki Fonseca, Hudson Silva Soares, João Fernando Alves Costa, Leiliane do Socorro Sodré de Souza, Anderson Mathias Pereira

DOI: 10.36229/978-65-86127-37-9.CAP.12 


\section{SUMÁRIO}

Capítulo 13: Pem type fuel cell polarization curve experimental determination 98

Roque Machado de Senna, Thais Santos, Henrique de Senna Mota, Marcelo Linardi

DOI: 10.36229/978-65-86127-37-9.CAP.13

Capítulo 14: Tratamento do efluente gerado na produção do biodiesel por meio da adsorção com pó de alto-forno e pó de minério

Ivan Pedro Arêdes Sousa Xavier, Lorena Ferreira Alves, Jamyla Soares Anício Oliveira Félix, Francine Duarte Castro

DOI: $10.36229 / 978-65-86127-37-9 . C A P .14$

Capítulo 15: Otimização do tratamento de água de manancial com baixa turbidez e cor elevada utilizando filtração direta e dupla filtração. 109

Bruno Castro Barbalho, André Luis Lopes Moriyama, André Luis Calado Araújo, André Luis Santos de Pinho

DOI: $10.36229 / 978-65-86127-37-9 . C A P .15$

Capítulo 16: Determinação da concentração dos metais Al, Cr e Ni em amostras de açaí (Euterpe Oleracea) do Rio Murucupi em Barcarena (Pará, Brasil)

Lucas Botelho Jerônimo, Cibele Cintia Lopes Pires, Marcia Lídia Bastos da Silva, Charles Miller de Souza Borges, Alexsandro Sozar Martins, Kelly das Graças Fernandes Dantas, Bianca Silva da Fonseca Alves

DOI: $10.36229 / 978-65-86127-37-9 . C A P .16$

Capítulo 17: Estudo da caracterização química de baterias de íon-lítio obsoletas..... 132

Keylla Castro Ferreira, Silvane Gonçalves e Gonçalves, Kleber Bittencourt Oliveira, Emanuel Negrão Macêdo, José Antônio da Silva Souza

DOI: $10.36229 / 978-65-86127-37-9 . C A P .17$

Capítulo 18: Produção de sabão ecológico a partir do óleo vegetal extraído da semente de Cupuaçu 137

Samara de Paula Pinheiro Menezes Marques, Mário Lucivaldo Barreto de Jesus, Rafaela Oliveira Pinheiro DOI: 10.36229/978-65-86127-37-9.CAP.18

Autores: 


\title{
Capítulo 1
}

\section{Estudo físico-químico de sucos de limão em pó comercializados em Belém do Pará}

\author{
Jackeline Kerlice Mata Gonçalves \\ João Pedro dos Reis Lima \\ Ewerton Carvalho de Souza \\ Ivan Carlos da Costa Barbosa \\ Elio Ferreira de Moraes Junior \\ Allyson Allennon Pinheiro do Rosário \\ Charles Alberto Brito Negrão \\ Antonio dos Santos Silva \\ Ewerton Reginaldo dos Santos Neves
}

Resumo: Sucos artificiais em pó são produzidos em larga escala no Brasil e fazem parte do cotidiano do consumidor brasileiro, tanto por seu baixo custo quanto por sua praticidade. 0 objetivo deste trabalho foi investigar alguns parâmetros físico-químicos destes sucos artificiais em pó de sabor limão produzido e comercializado em Belém do Pará, com a intenção de contribuir para o controle de qualidade destes. Os parâmetros considerados foram: densidade, condutividade elétrica (CE), por meio do condutivímetro, a análise de $\mathrm{pH}$, fazendo uso do pHmetro, sólidos solúveis totais (SST), pelo método de refratometria e acidez total titulável por meio da titulação ácido base, sendo todas as análises realizadas em triplicata. Com isso, a condutividade elétrica apresentada foi $0,96 \mathrm{mS} / \mathrm{cm}(\mathrm{A})$ e 1,10 mS/cm (B). 0 pH variou entre 2,60 (A) e 2,58 (B).

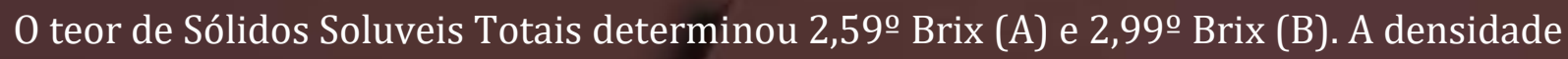
diferenciou entre $0,95 \mathrm{~g} / \mathrm{mL}(\mathrm{A})$ e $0,98 \mathrm{~g} / \mathrm{mL}(\mathrm{B})$. No que se refere a umidade, obteve-se 0,68\% (A) e 6,36\% (B); e a acidez total titulável foi de 4,45\% (A) e 5,08\% (B). Parâmetros estes que se mostraram semelhantes aos poucos estudos realizados com sucos artificiais em pó de sabor limão, mas concordantes com a legislação vigente, demonstrando atender ao controle de qualidade estabelecido. Já aplicação de análise de componentes principais e de análise hierárquica de agrupamentos se revelaram eficazes na discriminação das amostras de acordo com a fábrica produtora do suco.

Palavras-Chave: Bebidas não-alcoólicas, controle de qualidade, análises multivariadas. 


\section{INTRODUÇÃO}

O suco de limão é constantemente utilizado tanto para fins medicinais tanto para o preparo de sucos naturais da fruta. "As frutas cítricas, compreendidas principalmente por laranjas, tangerinas, limões, limas e pomelos, desempenham um papel importante na alimentação humana, principalmente sob a forma de fruta fresca e suco" (SENNA et al., 2007).

Segundo o Decreto N. 6.871, de 4 de junho de 2009, "concentrado sólido ou preparado sólido para refresco é o produto a base de suco ou extrato vegetal da sua origem e açúcares, destinado à elaboração de bebida para o consumo, após sua diluição em água potável, podendo ser adicionado de edulcorante hipocalórico e não calórico" (BRASIL, 2009). E a grande procura no mercado por estes se dá pois é de fácil preparo e possuem um preço de mercado mais acessível que as bebidas prontas para o consumo, tais como refrigerantes e sucos naturais.

Diante disso, "com o aumento da industrialização, a busca por praticidade e facilidade na alimentação proporcionou o crescimento no consumo de produtos como sucos artificiais" (MARMITT et al., 2016) e em virtude da fácil acessibilidade da população a estes preparados sólidos, o quanto eles são utilizados seja por seu baixo custo ou praticidade e a carência de trabalhos associados a estes preparados de sabor limão propôs-se uma análise físico-química visando analisar bem como diferenciar o mesmo produto produzido por marcas distintas.

\section{OBJETIVOS}

Este trabalho teve como objetivo a caracterização físico-química de suco em pó de limão, produzidos por duas indústrias, na formulação tradicional, com a intenção de realizar uma comparação entre as mesmas, via análise multivariada, para contribuir no controle de qualidade de ambas.

\section{MATERIAIS E MÉTODOS}

\subsection{AMOSTRAS}

Foram coletadas 10 amostras de suco em pó de limão, de duas fábricas distintas, totalizando 20 amostras. Estas foram adquiridas em Belém do Pará. As amostras foram levadas para o Laboratório de Física Farmacêutica da Faculdade de Farmácia da UFPA para realizar as análises físico-químicas, seguindo metodologias estabelecidas pelas normas analíticas do Instituto Adolfo Lutz (2008), tendo sido cada parâmetro realizado em triplicata.

\subsection{PARÂMETROS FÍSICO-QUÍMICOS}

Foram analisados os seguintes parâmetros físico-químicos:

\subsubsection{DETERMINAÇÃO DE PH}

0 suco artificial em pó de ambas as marcas foi previamente preparado em um béquer de acordo com o manual contido na embalagem. Em seguida, se introduziu o eletrodo de um pHmetro previamente calibrado com soluções tampão de pH 4,0 e 7,0. Fez a leitura direta no visor do aparelho.

\subsubsection{CONDUTIVIDADE ELÉTRICA (CE)}

Para a determinação da condutividade elétrica foi utilizado o mesmo suco preparado para a medição de pH, com o eletrodo de um condutivímetro portátil previamente calibrado com solução padrão de 1,43 $\mathrm{mS} / \mathrm{cm}$, indicando a condutividade elétrica da solução diretamente no visor do aparelho. 


\subsubsection{DENSIDADE}

Foi utilizada uma proveta de $10 \mathrm{~mL}$, sendo que a massa de pó contida nesta foi medida com o emprego de uma balança analítica. A densidade foi determinada através da equação.

$$
d(g / m L)=\frac{m}{V}
$$

\subsubsection{SÓLIDOS SOLÚVEIS TOTAIS (SST)}

Foram determinados através de leitura direta em refratômetro portátil (Instrutherm, modelo ATAGO 090), colocando-se sobre o prisma 1 ou 2 gotas da amostra do suco artificial sabor limão, sendo o valor de SST lido diretamente na escala do aparelho, em $\stackrel{\circ}{\text { Brix. }}$

\subsubsection{ACIDEZ}

0 método utilizado para determinar a acidez foi a titulação ácido-base. Pesaram-se cerca de $5 \mathrm{~g}$ de cada amostra e este foi transferido para um Erlenmeyer de $125 \mathrm{~mL}$, diluindo-se a alíquota com $50 \mathrm{~mL}$ de água destilada. Adicionaram-se de 2 a 4 gotas de solução fenolftaleína a $1 \%$, e foi titulado com solução de hidróxido de sódio $0,01 \mathrm{~mol} / \mathrm{L}$, até a solução adquirir uma coloração levemente rósea. Para o cálculo da acidez se empregou a equação (2), onde $\mathrm{V}$ é o volume consumido na titulação, em $\mathrm{mL}$, da solução de hidróxido de sódio $0,01 \mathrm{~mol} / \mathrm{L}$, f é o fator de correção da solução de hidróxido de sódio empregada, $\mathrm{m}$ representa a massa de licor, em g, da amostra usado na titulação e 1000 é o fator de diluição da amostra inicial.

$$
\operatorname{Acidez}(\%)=\frac{\text { V.f.N.1000. }}{m}
$$

\subsubsection{TEOR DE UMIDADE}

Esta determinação foi feita pelo método gravimétrico, ou seja, pesaram-se cerca de $2 \mathrm{~g}$ de cada amostras em cadinhos previamente tarados, e o conjunto amostra mais cadinho foi, então, posto a 105o $\mathrm{C}$ em estufa por $24 \mathrm{~h}$. Depois as amostras foram resfriadas em descessecador, sendo novamente pesadas. A umidade foi então determinada pela equação (3), onde $m_{f}$ é a massa depois da secagem na estufa (cadinho mais resíduo), $\mathrm{m}_{0}$ é a massa de pó do suco inicialmente pesada e $\mathrm{m}_{\mathrm{c}}$ é a massa do cadinho vazio.

$$
\text { Umidade }(\%)=100-\left(\frac{\left(m_{f}-m_{c}\right)}{m_{0}} .100\right)
$$

\subsection{ANÁLISES ESTATÍSTICAS DOS DADOS}

0 teste $t$ de Student foi aplicado aos dados encontrados para se avaliar se os valores médios obtidos para cada um dos parâmetros analisados são significativamente diferentes ou não de acordo com a marca do suco em pó de limão estudada, sendo o resultado expresso em letras, que, se iguais, indicam não haver diferença significativa entres as médias obtidas para os dois conjuntos amostrais (duas marcas de sucos em pó), com 95 \% de significância.

Aos dados que apresentaram diferença significativa entre as marcas de sucos em pó de limão, foi aplicada a técnica estatística multivariada de análise de componentes principais (ACP) e a técnica de análise hierárquica de agrupamentos (AHA) com o intuito de verificar se tais parâmetros são suficientes na discriminação do produto conforme a fábrica de origem. 


\section{RESULTADO E DISCUSSÃO}

Os resultados das análises físico-químicas estão expostos na Tabela 1, no qual são apresentados valores médios de três determinações por amostra, seguido do desvio padrão.

Tabela 1 - Resultados dos seis parâmetros estudados para os sucos artificiais em pó

\begin{tabular}{|c|c|c|c|c|c|c|}
\hline Amostra & $\mathrm{pH}$ & $\begin{array}{c}\mathrm{CE} \\
(\mathrm{mS} / \mathrm{cm})\end{array}$ & $\begin{array}{c}\text { SST } \\
\left({ }^{\circ} \text { Brix }\right)\end{array}$ & $\begin{array}{c}\text { Densidade } \\
(\mathrm{g} / \mathrm{mL})\end{array}$ & $\begin{array}{c}\text { Umidade } \\
(\%)\end{array}$ & $\begin{array}{c}\text { Acidez } \\
(\%)\end{array}$ \\
\hline $\mathrm{A} 1$ & $2,60 \pm 0,00$ & $0,92 \pm 0,01$ & $2,27 \pm 0,12$ & $0,83 \pm 0,04$ & $0,58 \pm 0,09$ & $4,33 \pm 1,07$ \\
\hline $\mathrm{A} 2$ & $2,60 \pm 0,00$ & $0,95 \pm 0,03$ & $2,33 \pm 0,12$ & $0,93 \pm 0,01$ & $1,12 \pm 0,15$ & $4,95 \pm 1,07$ \\
\hline $\mathrm{A} 3$ & $2,60 \pm 0,00$ & $0,97 \pm 0,01$ & $2,60 \pm 0,00$ & $0,96 \pm 0,01$ & $1,15 \pm 0,10$ & $4,33 \pm 1,07$ \\
\hline $\mathrm{A} 4$ & $2,60 \pm 0,00$ & $0,96 \pm 0,01$ & $2,60 \pm 0,00$ & $0,97 \pm 0,02$ & $1,12 \pm 0,15$ & $4,95 \pm 1,07$ \\
\hline A5 & $2,60 \pm 0,00$ & $0,96 \pm 0,01$ & $2,67 \pm 0,12$ & $0,95 \pm 0,03$ & $1,26 \pm 0,05$ & $3,71 \pm 0,00$ \\
\hline A6 & $2,60 \pm 0,00$ & $0,96 \pm 0,00$ & $2,53 \pm 0,12$ & $0,97 \pm 0,01$ & $0,56 \pm 0,10$ & $3,71 \pm 0,00$ \\
\hline A7 & $2,60 \pm 0,00$ & $0,96 \pm 0,02$ & $2,67 \pm 0,12$ & $0,98 \pm 0,00$ & $0,15 \pm 0,05$ & $4,38 \pm 1,03$ \\
\hline A8 & $2,60 \pm 0,00$ & $0,97 \pm 0,02$ & $2,67 \pm 0,12$ & $0,98 \pm 0,01$ & $0,52 \pm 0,01$ & $4,50 \pm 1,11$ \\
\hline A9 & $2,60 \pm 0,00$ & $0,96 \pm 0,02$ & $2,73 \pm 0,12$ & $0,97 \pm 0,01$ & $0,17 \pm 0,03$ & $4,50 \pm 1,11$ \\
\hline A10 & $2,60 \pm 0,00$ & $0,95 \pm 0,01$ & $2,80 \pm 0,00$ & $0,95 \pm 0,06$ & $0,13 \pm 0,02$ & $5,14 \pm 1,11$ \\
\hline Geral & $2,60^{a} \pm 0,05$ & $0,96^{a} \pm 0,02$ & $2,59^{a} \pm 0,18$ & $0,95^{a} \pm 0,05$ & $0,68^{a} \pm 0,45$ & $4,45^{a} \pm 0,93$ \\
\hline B1 & $2,60 \pm 0,00$ & $1,20 \pm 0,01$ & $3,00 \pm 0,00$ & $1,00 \pm 0,02$ & $6,51 \pm 0,12$ & $4,95 \pm 1,07$ \\
\hline $\mathrm{B} 2$ & $2,60 \pm 0,00$ & $1,12 \pm 0,03$ & $3,00 \pm 0,00$ & $1,01 \pm 0,02$ & $4,99 \pm 1,10$ & $4,95 \pm 1,07$ \\
\hline B3 & $2,60 \pm 0,00$ & $1,11 \pm 0,01$ & $2,93 \pm 0,12$ & $1,00 \pm 0,01$ & $4,51 \pm 0,43$ & $4,95 \pm 1,07$ \\
\hline B4 & $2,60 \pm 0,00$ & $1,11 \pm 0,01$ & $3,00 \pm 0,00$ & $1,01 \pm 0,01$ & $7,71 \pm 0,23$ & $4,95 \pm 1,07$ \\
\hline B5 & $2,60 \pm 0,00$ & $1,09 \pm 0,01$ & $3,00 \pm 0,00$ & $1,01 \pm 0,00$ & $11,36 \pm 1,38$ & $4,33 \pm 1,07$ \\
\hline B6 & $2,60 \pm 0,00$ & $1,09 \pm 0,00$ & $3,00 \pm 0,00$ & $0,99 \pm 0,01$ & $5,13 \pm 0,10$ & $4,95 \pm 1,07$ \\
\hline B7 & $2,60 \pm 0,00$ & $1,07 \pm 0,02$ & $3,00 \pm 0,00$ & $0,96 \pm 0,02$ & $4,42 \pm 0,31$ & $5,02 \pm 1,14$ \\
\hline B8 & $2,60 \pm 0,00$ & $1,08 \pm 0,02$ & $3,00 \pm 0,00$ & $0,95 \pm 0,01$ & $8,97 \pm 0,91$ & $5,79 \pm 0,00$ \\
\hline B9 & $2,50 \pm 0,00$ & $1,08 \pm 0,02$ & $3,00 \pm 0,00$ & $0,97 \pm 0,02$ & $3,93 \pm 0,39$ & $5,14 \pm 1,11$ \\
\hline $\mathrm{B} 10$ & $2,50 \pm 0,00$ & $1,05 \pm 0,01$ & $3,00 \pm 0,00$ & $0,91 \pm 0,09$ & $6,13 \pm 0,66$ & $5,79 \pm 0,00$ \\
\hline Geral & $2,58^{a} \pm 0,04$ & $1,10^{\mathrm{b}} \pm 0,04$ & $2,99 b \pm 0,04$ & $0,98^{a} \pm 0,04$ & $6,36^{b} \pm 2,35$ & $5,08^{b} \pm 0,91$ \\
\hline
\end{tabular}

Legenda: Letras iguais sobre as médias gerais dos parâmetros (na mesma coluna) significam não haver diferença significativa, com 95\% de confiança, conforme teste t de Student (VIEIRA, 2011).

O suco de limão em pó, recém preparado apresentou o pH médio de 2,6 (marca A) e 2,58 (marca B) sendo estes classificados como ácidos de acordo com a escala (pH menor que 7). Valores aproximados a estes são encontrados na literatura em sucos de limão tahiti natural (PEDRAO, 1999), e sucos industrializados e preparados tanto de sabor limão quanto de demais frutas cítricas (DA SILVA et. al., 2013).

Ao falar sobre Condutividade Elétrica (CE), estamos falando sobre a possibilidade de determinados matérias conduzirem energia elétrica. Com isso, a (CE) média encontrada para as marcas analisadas foi de $0,96 \mathrm{mS} / \mathrm{cm}$ (marca A) e $1,10 \mathrm{mS} / \mathrm{cm}$ (marca B).

As amostras A e B obtiveram valores de densidade de $0,95 \mathrm{~g} / \mathrm{mL}$ e $0,98 \mathrm{~g} / \mathrm{mL}$ respectivamente.

O teor dos Sólidos Solúveis Totais (SST) representa a quantidade de sólidos dissolvidos na água, como açúcar, proteínas e é medido em ${ }^{\circ}$ Brix, que é utilizada nas indústrias para verificação do controle de qualidade dos alimentos produzidos. O SST obtido foi de 2,59 Brix (marca A) e de 2,99o Brix (marca B), sendo que estes valores se assemelham aos valores encontrados na análise de sucos artificiais cítricos (DA SILVA et al., 2013), preparados sólidos para refrescos (DA SILVA et al., 2018) e bebidas industrializadas.

Segundo Furtado; Ferraz (2007), "o percentual de umidade é uma das principais determinações analíticas realizadas com o propósito de verificar padrões de identidade e qualidade em alimentos, além de auxiliar na tomada de decisão em várias etapas do processamento, como escolha da embalagem, modo de estocagem do produto, etc." Na marca A foi possível detectar o teor de umidade a 0,68\% enquanto na marca B, o teor está a 6,36\%.

A acidez presente em bebidas exerce influência quanto a diminuição do $\mathrm{pH}$ da saliva, diminuindo sua função como solução tampão, ou seja, como proteção para a arcada dentária. Por isso a necessidade de se avaliar o índice de acidez também como parâmetro de qualidade. Para os sucos artificiais em pó, os valores encontrados para acidez foram de 4,45 \% (marca A) e 5,08\% (marca B).

A aplicação de ACP produziu o gráfico presente na Figura 1. 
Figura 1. Gráfico das duas primeiras componentes principais

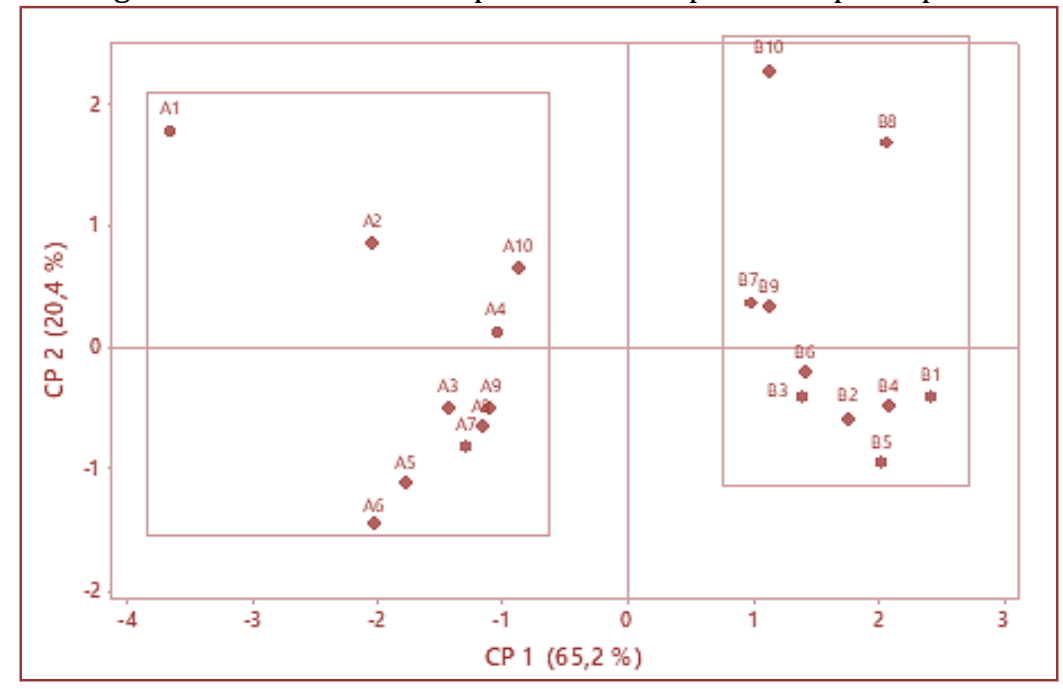

Pelo gráfico acima se percebe que os parâmetros investigados foram suficientes para a distinção dos sucos de limão em pó de acordo com a sua fábrica produtora, sendo que as duas primeiras componentes principais juntas explicam $85,6 \%$ da variabilidade dos dados.

A aplicação da AHA produziu o dendrograma dado na Figura 2.

Figura 2. Dendrograma obtido para as amostras través de dados padronizados e ligação direta através de distâncias euclidianas

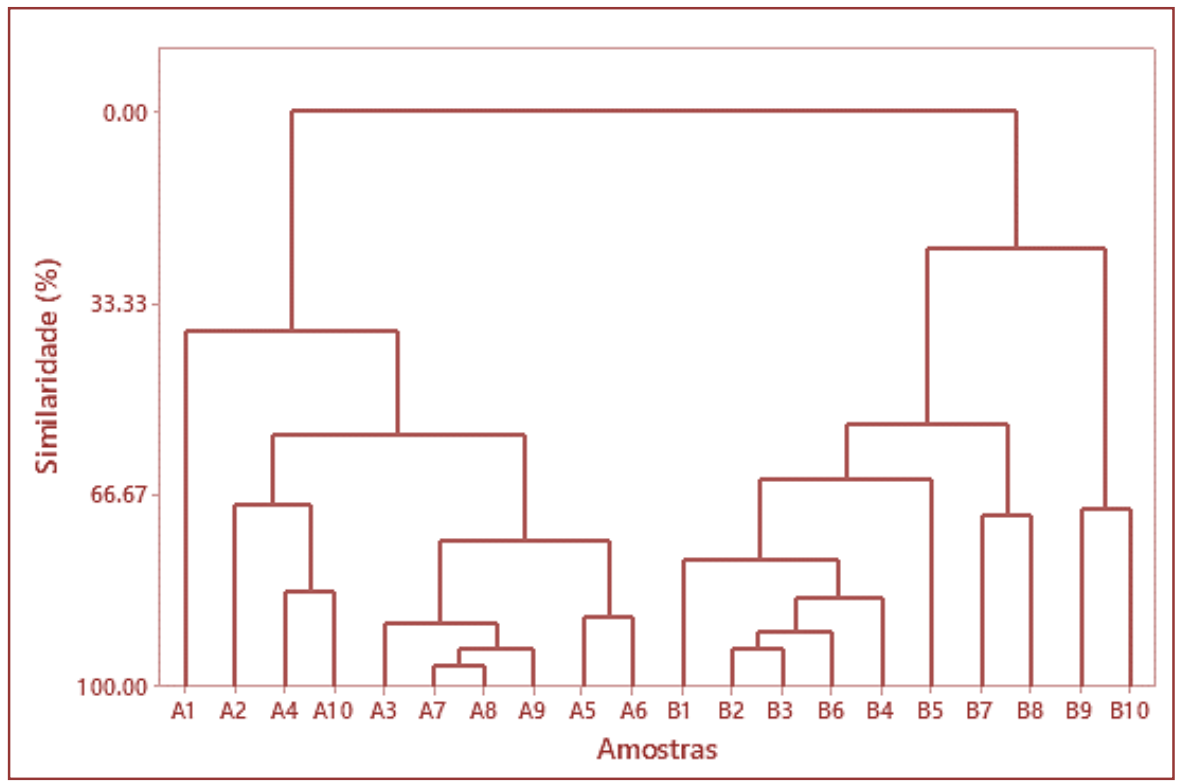

Percebe-se pela Figura 2 que as amostras da marca A são totalmente diferentes das amostras da marca B, em termos de seus parâmetros físico-químicos analisados, pois apresentaram 0 \% de similaridade. Desta forma, tais parâmetros são suficientes para discriminar as amostras conforme a fábrica produtora.

\section{CONCLUSÃO}

Os resultados das análises empregadas e realizadas objetivaram avaliar a qualidade dos preparados sólidos para refrescos, bem como visando comparar as duas marcas e a posteriori, estas com os demais trabalhos encontrados na literatura além do que é proposto pela lei brasileira vigente. Ressaltando que são inúmeros os fatores que podem influenciar e consequentemente alterar as características físicoquímicas e estas análises possibilitam identificar possíveis falhas quer seja na produção ou no 
armazenamento comprometendo a qualidade do produto e a saúde da população. A ACP e a AHA aplicadas aos dados obtidos se mostraram suficientes e eficientes na discriminação dos sucos de limão em pó de acordo com a fábrica produtora, indicando que elas podem ser útil no controle de qualidade desse produto.

\section{REFERENCIAS}

[1] Brasil. Decreto federal № 6.871, de 4 de Junho de 2009. Regulamenta a Lei no 8.918, de 14 de julho de 1994, que dispões sobre a padronização, a classificação, o registro, a inspeção, a produção e a fiscalização de bebidas. Ministério da Agricultura, Pecuária e Abastecimento, 2009. Disponível em: http://www.planalto.gov.br/ccivil_03/_Ato2007-2010/2009/Decreto/D6871.htm., v. 8, n. 4, 2016.

[2] Brasil. Ministério da Agricultura, Pecuária e Abastecimento. Decreto no 6.871, de 4 de Julho de 2009. Dispõe sobre a padronização, a classificação, o registro, a inspeção, a produção e a fiscalização de bebidas. Diário Oficial [da] República Federativa do Brasil. Brasília, Df, 05 de jun.2009.

[3] Brasil. Ministério da Agricultura, Pecuária e Abastecimento. Instrução Normativa n. 55, de 31 de outubro de 2008. Diário Oficial da União. Brasília, DF, 31 de out. 2008.

[4] Da Silva, Ayonara Dayane Leal; de Vasconcelos Catão, Maria Helena Chaves; de Oliveira, Ricardo Miguel. Propriedades físico-químicas de preparados sólidos para refrescos e sucos industrializados. Revista da Faculdade de Odontologia-UPF, v. 18, n. 1, 2013.

[5] Da Silva, Gabriel Monteiro et al. Propriedades Físico-Químicas de Preparados Sólidos para Refrescos e Sucos Industrializados. In: Congresso Nacional de Pesquisa e Ensino em Ciências, 3., 2018, Campina Grande. Anais eletrõnicos... $\quad$ Campina $\quad$ Grande: $\quad$ Realize, $2018 . \quad$ Disponível em: <http://editorarealize.com.br/revistas/conapesc/trabalhos/Trabalho_EV107_Md1_SA16_Id570_24052018212005.pd f> Acesso em: 01 Ago. 2019.

[6] Furtado, M.A.M.; Ferraz, F.O Determinação de Umidade em Alimentos por Intermédio de Secagem em Estufa Convencional e Radiação Infravermelha - Estudo Comparativo Em Alimentos Com Diferentes Teores de Umidade. Ufj: 2007. Disponível em: < http://www.ufff.br/laaa/files/2008/08/04-7\%C2\%BA-Slaca-2007.pdf >. Acesso em: 09 maio 2019.

[7] Instituto Adolfo Lutz. Normas Analíticas do Instituto Adolfo Lutz. Métodos físico-químicos para análises de alimentos. $4^{\mathrm{a}}$ ed. (1 $1^{\mathrm{a}}$ Edição digital), 2008.

[8] Minim, V. Análise sensorial: estudos com consumidores. 3. ed. Viçosa, MG: UFV, 2013.

[9] Pedrao, Mayka R. et al . Estabilidade físico-química e sensorial do suco de limão Tahiti natural e adoçado, congelado. Ciênc. Tecnol. Aliment., Campinas , v. 19, n. 2, p. 282-286, May 1999. Available from $<$ http://www.scielo.br/scielo.php?script=sci_arttext\&pid =S0101-20611999000200023\&lng= en\&nrm=iso >. Acesso em 05 Ago. 2019.

[10] Senna, Ana Júlia Teixeira; Pedrozo, Eugenio Ávila; Koller, Otto Carlos. Identificação e análise da cadeia de distribuição das frutas cítricas de mesa sem sementes: um estudo de caso na cidade de São Paulo. Revista brasileira de fruticultura. Jaboticabal, SP. Vol. 29, n. 3 (dez. 2007), p. 508-512, 2007.

[11] Vieira, S. Introdução à Bioestatística. 4⿳⺈ ed. Rio de Janeiro: Elsevier, 2011. 


\section{Capítulo 2}

Caracterização fisico-química, determinação de compostos bioativos e capacidade antioxidante em garrafada de espinheira santa (Maytenus ilicifolia)

\section{Endril Pablo Brasil de Freitas}

Rayana Silva Craveiro

João Marcos Batista de Assunção

Yasmin Martins dos Santos Lopes

Alan Moura Feio

Denison Barros Soares

Mayara Martins Galvão

Denilson Barreto da Luz.

Elivaldo Nunes Modesto Junior

Resumo: 0 objetivo foi realizar a caracterização físico-química, quantificação dos compostos bioativos e avaliação da capacidade antioxidante da garrafada de Espinheira Santa (Maytenus ilicifolia). A garrafada foi adquirida em um comércio no município de Soure, na Ilha de Marajó - PA e posteriormente encaminhada para o Laboratório de Ciências Naturais da Universidade do Estado do Pará, no Campus XIX/Salvaterra. Foram realizadas análises físico-químicas $(\mathrm{pH}$, densidade, acidez livre, umidade, cinzas e açúcares redutores), compostos bioativos (fenóis e flavonoides) e capacidade antioxidante. Os resultados obtidos foram: $\mathrm{pH}(4,85)$, acidez livre $(7,03 \mathrm{mEq}$. de $\mathrm{NaOH} / \mathrm{kg}-1)$, densidade $(0,9978 \mathrm{~g} / \mathrm{cm} 3)$, umidade $(99,4 \%)$, cinzas $(0,12 \%)$ e açúcares redutores (não detectado). Para a quantificação dos compostos bioativos se obteve para fenóis totais $(24,62 \mathrm{mg}$ EAG/mL) e flavonoides $(15,14 \mathrm{mg}$ ER/mL). Em relação a capacidade antioxidante foi obtido um CE50 de 48,89 mg/mL. Os resultados mostraram que a garrafada possui atributos que podem beneficiar a saúde humana, no entanto o valor de pH e o índice de acidez encontrados denotam dados preocupantes com relação ao consumo diário deste produto. Dessa forma, estudos adicionais são necessários não somente para validar cientificamente os benefícios que as garrafadas podem trazer no tratamento correto de doenças, mas também para analisar seus possíveis efeitos colaterais ao organismo humano. 


\section{INTRODUÇÃO}

A garrafada é uma solução constituída por uma combinação de plantas medicinais veiculadas em um líquido extrator, geralmente hidroalcoólico e tais preparações são amplamente difundidas entre a população, pois são utilizadas com inúmeras finalidades terapêuticas na medicina popular (Passos, 2018). De acordo com Camargo (2011, p. 02), as formulações são complementadas com elementos religiosos próprios dos sistemas de crenças vigentes no Brasil. Em geral, utiliza-se em seu preparo o vinho, a água ou mel e a combinação de partes de espécies vegetais como cascas, frutos, folhas, raízes ou flores, secas e frescas, podendo ser também acrescentados elementos de origem animal ou mineral (Dantas et al., 2008). Podem ser administradas por via oral, mas também é possível encontrar garrafadas para administração por via tópica e inalatória. Dentre os diversos espécimes utilizados em seu preparo, destaca-se a Maytenus ilicifolia, que é uma planta medicinal originária do Brasil, pertencente à família Celastraceae, e popularmente conhecida como Espinheira Santa (Lorenzi e Matos, 2002 a; Brandão et al., 2006). Essa espécie caracteriza-se como uma árvore de pequeno porte ou arbusto grande, dotada de copa arredondada e densa, nativa da região sul do Brasil, com folhas coriáceas, brilhantes e margens providas de espinhos maleáveis. Suas flores são pequenas e de cor amarelada e os frutos, na forma de cápsulas oblongas, deiscentes de coloração vermelha, podendo conter de 1 á 2 sementes de cor preta (Lorenzi e Matos, 2002 b). Segundo o conhecimento tradicional, acredita-se que a Espinheira Santa possa atuar no combate de várias doenças como úlcera, gastrite, dispepsias, além de possuir ações analgésicas, antissépticas, cicatrizantes, diuréticas, laxativas, antibacterianas e antioxidantes.

De acordo com Lima et al. (1969), tais qualidades são conferidas a Maytenus ilicifolia devido a presença de vários grupos fitoquímicos, dentre os quais pode-se destacar os compostos fenólicos e flavonóides, os quais atuam capturando radicais livres impedindo ou minimizando o estresse oxidativo, ocasionado pelo desequilíbrio funcional de um organismo. Conforme Tibert et al. (2006), entre as substâncias químicas pertencentes a classe dos flavonoides, que se fazem presentes nas folhas do vegetal ressalta-se o canferol3-hexose, o canferol-3-ramno-hexose, a quercetina-3-di-(ramno)-hexose, a quercitrina (quercetina-3ramnose) e a rutina (quercetina-3-Glu-ram).

Apesar das garrafadas serem amplamente produzidas e comercializadas é evidente que existem uma insuficiência de estudos científicos que comprovem as propriedades terapêuticas presentes nas garrafadas, pois sua utilização se baseia somente na eficácia do consumo no tratamento de determinadas patologias, sem nenhum conhecimento dos princípios envolvidos em suas ações benéficas. Além disso, conforme Passos (2018), as garrafadas não são submetidas a nenhum teste de qualidade, uma vez que não existe regulamentação sanitária acerca desse tipo de produto, o que torna imprescindível a realização de estudos que gerem dados capazes de subsidiar o estabelecimento de critérios mínimos de segurança quanto ao consumo e composição. Diante disso, o presente estudo objetivou realizar a caracterização físico-química, quantificação dos compostos bioativos e avaliação da capacidade antioxidante da garrafada de Espinheira Santa (Maytenus ilicifolia), como forma de verificar a qualidade e o potencial terapêutico deste produto.

\section{METODOLOGIA}

A pesquisa foi desenvolvida na Universidade do Estado do Pará, Campus XIX, Salvaterra, Ilha de Marajó, Pará. A garrafada foi adquirida no mercado da cidade de Soure e posteriormente encaminhada para a realização das análises no Laboratório de Ciências Naturais.

\subsection{PARÂMETROS FÍSICO-QUÍMICOS}

Para calcular a densidade da amostra realizou-se o método com picnômetro, o qual consiste na medida da massa de um volume conhecido de líquido num recipiente denominado picnômetro. 0 mesmo foi calibrado em relação à massa da água pura a $20^{\circ} \mathrm{C}$ (INSTITUTO ADOLFO LUTZ, 2008). $0 \mathrm{pH}$ foi determinado com a medição da amostra em pHmetrô (MS TECNOPON $®$ ), previamente calibrado com solução tampão de pH 4,0 e 7,0. A acidez livre foi realizada pelo método titulométrico, com solução de Hidróxido de Sódio (NaOH) 0,1 M até que o pH atingisse a faixa de 8,5 (INSTITUTO ADOLFO LUTZ, 2008). A determinação de umidade da amostra foi realizada por meio de secagem por infravermelho, utilizando a balança de infravermelho modelo Gehaka, de acordo com manual do equipamento.

Para análise de cinzas realizou-se a desidratação dos cadinhos de porcelana em estufa (De Leo) à $105^{\circ} \mathrm{C}$ por $1 \mathrm{~h}$ até atingir peso constante, posteriormente os cadinhos foram colocados na chapa aquecedora para queima de parte da matéria orgânica e em seguida levadas ao forno mufla a $550^{\circ} \mathrm{C}$ por 3 horas (INSTITUTO ADOLFO LUTZ, 2008). 
0 teor de açúcares redutores foi realizado por meio do método de Lane-Eynon, com a utilização do reagente de Fehling. Preparou-se uma solução utilizando $5 \mathrm{~mL}$ da amostra com $50 \mathrm{~mL}$ de água destilada, aferiu-se esta solução em uma bureta de $50 \mathrm{~mL}$. Em seguida um erlenmeyer adicionou-se $5 \mathrm{~mL}$ de solução de Fehling A, $5 \mathrm{~mL}$ de solução de Fehling B e $20 \mathrm{~mL}$ de água destilada. A solução foi colocada em chapa aquecedora até a ebulição da mistura, após isso se adicionou uma gota de azul de metileno a 1\% e titulouse sob agitação constante até a formação do precipitado vermelho tijolo.

\subsection{DETERMINAÇÃO DE FENÓIS TOTAIS}

Para determinação do teor total de fenóis, utilizou-se o método espectrofotométrico Folin-Ciocalteau (Singleton, 2002). A amostra teve seu extrato liquido filtrado e a partir disso preparou-se uma solução metanólica na proporção de 1:3. Retirou-se uma alíquota de $0,5 \mathrm{~mL}$ desta e misturou-se com $2,5 \mathrm{~mL}$ do reagente Folin-Ciocalteau (10\%) e $2 \mathrm{~mL}$ de Carbonato de Sódio (7,5\%). A solução foi homogeneizada em vortex e aquecida em banho-maria (Hermoquímica ${ }^{\circledR}$ ) na temperatura de $50^{\circ} \mathrm{C}$ por $5 \mathrm{~min}$. A leitura foi realizada na absorbância de $760 \mathrm{~nm}$ no espectrofotômetro (Thermo Scientific ${ }^{\circledR}$ ), como branco utilizou-se metanol. Para construir a curva analítica de calibração foi utilizado como padrão o ácido gálico, nas concentrações de 20 a $120 \mu \mathrm{g} / \mathrm{mL}$. Com isso, foi obtida a Equação 1 da reta, com R $\mathrm{R}^{2}=0,9994$, a qual permitiu calcular o teor de compostos fenólicos, que foi expresso em mg EAG/mL de extrato liquido da amostra.

$$
y=0,0063 x-0,01
$$

\subsection{DETERMINAÇÃO DE FLAVONOIDES TOTAIS}

A quantificação de flavonoides foi determinada segundo o método descrito por Meda et al. (2005). A amostra foi filtrada e preparou-se uma solução metanólica na proporção de 1:3. Misturou-se 0,8 mL dessa solução com 0,8 mL de cloreto de alumínio (2\%) e 2,4 mL de metanol (MeOH). A solução foi homogeneizada em vortex e após $25 \mathrm{~min}$ realizou-se a leitura na absorbância de $413 \mathrm{~nm}$ no espectrofotômetro (Thermo Scientific $®$ ). A rutina foi utilizada como padrão nas concentrações de 20 a $120 \mu \mathrm{g} / \mathrm{mL}$ para se construir a curva de calibração, a qual gerou a equação 2 , com $\mathrm{R}^{2}=0,9999$. A partir disso, foi realizado o cálculo do teor de flavonoides totais, que foi expresso em $\mathrm{mg} \mathrm{ER} / \mathrm{mL}$ de extrato liquido da amostra.

$$
y=0,0072 x-0,0118
$$

\subsection{CAPACIDADE ANTIOXIDANTE}

Para avaliar a capacidade antioxidante da garrafada de Espinheira Santa, empregou-se o método descrito por Brand Williams (1995). Preparou-se uma solução metanólica de DPPH de $100 \mu \mathrm{M}$, ajustando-a para uma absorbância entre 0,620 a 0,630, mantendo sob refrigeração a $4^{\circ} \mathrm{C}$ até o momento das análises. Foram preparadas soluções metanólicas da amostra nas concentrações que variaram de 12 a $60 \mathrm{mg} / \mathrm{mL}$. Retirouse uma alíquota de $1 \mathrm{~mL}$ de cada concentração e misturou-se com 1,5 mL da solução de DPPH. Juntamente com as amostras foi preparado um controle negativo, constituído de $1 \mathrm{~mL}$ de metanol e 1,5 mL de DPPH. Os ensaios foram homogeneizados em vortex e colocados em repouso, abrigados da luz por 30 minutos. A absorbância foi lida no espectrofotômetro (Themo Scientífic $囚$ ) a $517 \mathrm{~nm}$ contra um branco contendo apenas metanol. Os valores obtidos na leitura foram convertidos em porcentagem da inibição por meio da equação 3.

\% de Inibição do DPPH = (Abs. controle negativo - Abs. amostra / Abs. Controle negativo) $\times 100$

Construiu-se um gráfico com as concentrações das amostras (eixo $\mathrm{x}$ ) versus a respectiva inibição (eixo y). Esta foi interpretada segundo uma linha de tendência reta, a qual se obteve a equação que permitiu estimar a concentração de amostra eficiente para reduzir a quantidade inicial de DPPH em 50\% (CE50). 


\section{RESULTADOS E DISCUSSÃO}

Os resultados obtidos para os parâmetros físico-químicos, fenóis totais e flavonoides da garrafada de Espinheira Santa (Maytenus ilicifolia) produzida no município de Soure - PA estão apresentados na Tabela 1.

Tabela 1 - Resultados obtidos para Parâmetros Físico-químicos e Compostos Bioativos

\begin{tabular}{|c|c|c|c|}
\hline \multicolumn{2}{|c|}{ Parâmetros Físico-químicos } & \multicolumn{2}{|c|}{ Compostos Bioativos } \\
\hline $\mathrm{pH}$ & $4,85 \pm 0,01$ & & \\
\hline Acidez Livre (meq.kg-1) & $7,03 \pm 0,90$ & Fenóis Totais (mg EAG/mL) & $24,62 \pm 0,19$ \\
\hline Densidade $\left(\mathrm{g} / \mathrm{cm}^{3}\right)$ & $0,9978 \pm 0,01$ & & \\
\hline Umidade (\%) & $99,4 \pm 0,25$ & Flavonoides (mg ER/mL) & $15,14 \pm 0,25$ \\
\hline Cinzas (\%) & $0,12 \pm 0,03$ & & \\
\hline Açúcares Redutores (\%) & Não detectado & & \\
\hline
\end{tabular}

A partir das análises realizadas obteve-se para $\mathrm{pH}$ e acidez os valores de 4,85 e 7,03 meq.kg-1, respectivamente. Dessa forma verificou-se que a garrafada apresentou um caráter ácido, o que pode ser prejudicial à saúde, visto que o consumo de produtos com essa característica pode favorecer a produção de ácidos no organismo ocasionando o desequilíbrio do pH sanguíneo. Evidencia-se que o pH e a acidez da garrafada podem ser influenciados diretamente pelo $\mathrm{pH}$ do vegetal Maytenus ilicifolia que a compõe, que por sua vez, está diretamente relacionado a fatores como o pH do solo onde a planta se encontra e ao clima da região a que ela pertence.

Para densidade obteve valor de $0,9978 \mathrm{~g} / \mathrm{cm}^{3}$ e apresentou um alto teor de umidade $(99,4 \%)$, justifica-se este valor devido o produto ser constituído em sua grande maioria por água, o que o torna suscetível à proliferação de fungos e bactérias, agentes que podem influenciar negativamente no produto, ocasionando sua contaminação e consequente deterioração. 0 teor de cinzas obtido foi de $0,12 \%$, supõe-se que a pequena quantidade do extrato da planta no produto refletiu diretamente em seu baixo teor de cinzas. Vale ressaltar que apesar de apresentar em sua composição substâncias que a conferem propriedades terapêuticas, a Maytenus ilicifolia é uma espécie que também apresenta certa toxicidade, o que pode explicar a quantidade reduzida do vegetal na garrafada. Além disso, destaca-se que não foi detectada a presença de açúcares redutores na amostra.

Em relação ao teor total de fenóis e flavonoides a garrafada apresentou um valor médio de 24,62 mg $\mathrm{EAG} / \mathrm{mL}$ e 15,14 mg ER/mL, respectivamente. Resultado superior ao apresentado neste estudo foi relatado por Santi et al. (2014) que ao investigarem o teor dos bioativos presentes em infusão da espécie medicinal Cordia verbenacea obtiveram o valor de 183,52 mg EAG/g para fenóis totais e 311,40 mgER/g para flavonoides. Conforme Negri, Possamai e Nakashima (2009), substâncias químicas como iterpenos, flavonóides, taninos e ácido fenólicos são as principais responsáveis por conferir a garrafada de Maytenus ilicifolia ás propriedades terapêuticas contra o câncer, gastrite, úlceras estomacais. Os valores obtidos para a capacidade antioxidante na amostra da garrafada foram expressos conforme mostra a Tabela 2.

Tabela 2 - Concentrações, índice de inibição percentual do radical DPPH e concentração eficiente da garrafada de Maytenus ilicifolia

\begin{tabular}{c|c|c|c|}
\multirow{2}{*}{ Amostra } & \multicolumn{2}{c}{$\begin{array}{c}\text { Concentração } \\
(\mathrm{mg} / \mathrm{mL})\end{array}$} & \multicolumn{2}{c|}{$\begin{array}{c}\text { CE50 } \\
(\mathrm{mg} / \mathrm{mL})\end{array}$} \\
\cline { 2 - 3 } & 12 & 13,49 & \multirow{3}{*}{48,89} \\
\cline { 2 - 3 } Garrafada de & 24 & 22,27 & \\
\cline { 2 - 3 } Espinheira Santa & 36 & 34,92 & \\
\cline { 2 - 3 } & 48 & 55,33 & \\
\cline { 2 - 3 } & 60 & 69,92 & \\
\hline
\end{tabular}


As concentrações no intervalo de 12 a $60 \mathrm{mg} / \mathrm{mL}$ promoveram uma inibição de 13,49 a 69,92\%, com valor de $\mathrm{CE}_{50}$ de 48,89 mg/mL. Resultado inferior ao obtido neste estudo, foi relatado por Veber et al. (2015) que ao verificarem a capacidade antioxidante de extratos aquosos de Jambolão (Syzygium cumini L.) obtiveram $\mathrm{CE}_{50}$ de 56,09 mg/mL. Segundo Santi et al. (2014), a atividade antioxidante pode ter uma relação quantitativa com a concentração de substâncias fenólicas e flavonoídica no produto. Conforme Tacon e Freitas (2013) os fenóis destacam-se por ser a classe de antioxidante mais importante, visto que sua estrutura química é capaz de sequestrar e inibir os radicais livres, responsáveis por causar danos oxidativos que podem desencadear inúmeras doenças degenerativas.

\section{CONCLUSÃO}

Com base nos resultados das análises realizadas pode-se constatar que este medicamento popular tem alguns atributos que podem beneficiar a saúde humana, no entanto o resultados de $\mathrm{pH}$ e o índice de acidez encontrados denotam dados preocupantes com relação ao consumo diário deste produto, tais fatores enaltecem a necessidade da existência de uma legislação que regule tanto seu comercio quanto sua produção, com ênfase nesta ultima visto que os meios de fabricação são em sua maioria questionáveis devido aos processos caseiros que são adotados para a extração e misturas dos componentes das garrafadas. Dessa forma, estudos adicionais são necessários não somente para validar cientificamente os benefícios que as garrafadas podem trazer no tratamento correto de muitas doenças, mas também para analisar seus possíveis efeitos colaterais ao organismo humano.

\section{REFERÊNCIAS}

[1] Brandão, M. G. L, et al. Medicinal plants and other botanical products from the Brazilian Official Pharmacopoeia. Rev. Bras. Farm., v.16, p. 408-420, 2006. DOI http://dx.doi.org/10.1590/S0102695X2006000300020. Disponível em: http://www.scielo.br/scielo.php?script=sci_arttext\&pid=S0102695X2006000300020. Acesso em: 04 set. 2019.

[2] Brand-Williams, W.; Cuvelier, M. E.; Berst, C. Use of a free radical method to evaluate antioxidant activity. Leb. Wis. Und. Tec., v.28, p. 25-30, 1995. DOI https://doi.org/10.1016/S0023-6438(95)80008-5. Disponível em: https://www.sciencedirect.com/science/article/pii/S0023643895800085. Acesso em: 04 set. 2019.

[3] Camargo, M. A garrafada na medicina popular: uma revisão historiográfica. Dominguezia, v.27, n.1, p. 41-49, 2011. Disponível em: http://www.dominguezia.org/volumen/articulos/2714.pdf. Acesso em: 04 set. 2019.

[4] Dantas, V. S. et al. Análise das garrafadas indicadas pelos raizeiros na cidade de Campina Grande-PB. Bio., v.3, n.1, p. 7-13, jan./mar. 2008. Disponível em: https://www.scienceopen.com/document?vid=3c9a634e-4270-4fac-ba7f288f79166e0e. Acesso em: 04 set. 2019.

[5] Lima, O. G. Substâncias antimicrobianas de plantas superiores. Rev Inst Anti, v.9, p. 17-25, 1969. Disponível em: $\quad$ http://www.scielo.br/scielo.php?script=sci_nlinks\&ref=000084\&pid=S0102695X200700040000600004\&lng=pt. Acesso em: 04 set. 2019.

[6] Lorenzi, H.; Matos, F.J.A. Plantas medicinais do Brasil: nativas e exóticas. São Paulo: Instituto Plantarum de Estudos da Flora, 2002. 512 p.

[7] Negri, M. L. S. Possamai, J. C. Nakashima, T. Atividade antioxidante das folhas de espinheira-santa - Maytenus ilicifoliaMart. ex Reiss., secas em diferentes temperaturas. Revista Brasileira de Farmacologia, v.19, p. 553-556, Abr./Jun. 2009. Disponível em: http://www.scielo.br/scielo.php?script=sci_arttext\&pid=S0102-695X2009000400007. Acesso em: 04 set. 2019.

[8] Passos, M. M. B. D. et al. A disseminação cultural das garrafadas no Brasil: um paralelo entre medicina popular e legislação sanitária. Saúde em Debate, v.42, n. 116, p. 248-262, jan./mar. 2018. Disponível em: http://www.scielo.br/scielo.php?pid=S0103-11042018000100248\&script=sci_abstract\&tlng=pt. Acesso em: 04 set. 2019.

[9] Santi, M. M. et al. Determinação do perfil fitoquímico de extrato com atividade antioxidante da espécie medicinal Cordia verbenácea por HPLC-DAD. Revista Brasileira de Plantas Medicinais, Campinas, v.16, n.2, p. 256-261, 2014. Disponível em: http://www.scielo.br/scielo.php?pid=S151605722014000200014\&script=sci_abstract\&tlng=pt. Acesso em: 04 set. 2019. 
[10] Singleton, V. L., Orthofer, R., Lamuela-RA Ventos, R. M. Analysis of total phenols and other oxidation substrates and antioxidants by means of Folin-Ciocalteu reagent. Methods in Enzymology., v.299, p. 152-178, 2002. Disponível em: https://www.sciencedirect.com/science/article/pii/S0076687999990171. Acesso em: 04 set. 2019.

[11] Tacon, L. A.; Freitas, L.A. P. Box- Behnken design to study the bergenin contente and antioxidante activity of Endopleura uchi barck extracts obtained by dynamic maceration. Revista Brasileira de Farmacologia, v.23, p. 65- 71, 2013. DOI http://dx.doi.org/10.1590/S0102-695X2012005000134. Disponível em: http://www.scielo.br/scielo.php?script=sci_arttext\&pid=S0102-695X2013000100009. Acesso em: 04 set. 2019.

[12] Tiberti, L. A. et al. Identification of flavonols in leaves of Maytenus ilicifolia and Maytenus aquifolium (Celastraceae) by LC/UV/MS analysis. Jou. Of. Chr. B., v. 846, n. 2, p. 378-384, 2006. DOI: 10.1016/j.jchromb.2006.09.014. Disponível em: https://www.ncbi.nlm.nih.gov/pubmed/17011840. Acesso em: 04 set. 2019.

[13] Veber, J. et al. Determinação dos compostos fenólicos e da capacidade antioxidante de extratos aquosos e etanólicos de Jambolão (Syzygium cumini L.). Revista Brasileira de Plantas Medicinais, Campinas, v.17, n.2, p. 267-273, 2015. DOI http://dx.doi.org/10.1590/1983-084X/12_181. Disponível em: http://www.scielo.br/scielo.php?script=sci_arttext\&pid=S1516-05722015000200267. Acesso em: 04 set. 2019. 


\section{Capítulo 3}

Quantificação de carbamatos por Extração QuEChERS e CLAE em melancia, Cultivar Crimson Sweet, comercializada em Boa Vista - RR

Maria Janes de Oliveira Santos

Resumo: 0 Programa de Analise de Resíduos de Agrotóxicos em Alimentos(PARA), divulgou em 2013, uma planilha de Limite Máximo de resíduos(LMR),onde foi investigado uma variedade de alimentos, o qual a melancia não fez parte. Foram incluídos algumas cidades do País, entre elas, encontra-se Roraima, porém o cultivo de melancia não foi investigado.A ANVISA especifica que o limite máximo de resíduo (LMR) em diferentes tipos de agrotóxicos é de 0,1 mg.kg-1 . São 242 ingredientes ativos pesquisados em diversos cultivos de frutas,vegetais e grãos, pela ANVISA. Este trabalho foi realizado com o objetivo de estudar o método QuEChERS para a determinação analítica de resíduos de agrotóxicos em melancia comercializada em Boa Vista - Roraima. Foram estudados 11 agrotóxicos que pertence ao grupo orgânico mais versátil dos pesticidas, os carbamatos, podendo funcionar como inseticidas, herbicidas, fungicidas e até anti-bacterianos, sendo sua determinação efetuada em cromatografo liquido de alta eficiência. Foram avaliados os parâmetros: seletividade, linearidade, limite de detecção, limite de quantificação, recuperação, robustez, exatidão e precisão. Os testes realizados demonstram que o método proposto é viável, obtendo os valores dos limites de quantificação e qualificação menores de $20 \%$, para determinação e quantificação das substâncias estudadas em amostras complexas de melancia.

Palavras - chave: Carbamato, QuEChERS, agrotóxico. 


\section{INTRODUÇÃO}

A utilização de substâncias químicas como defensivos agrícolas iniciou-se na década de 20, mas só depois da segunda guerra mundial tais produtos passaram a desempenhar um papel de crescente relevância na agricultura (Peres,1999). O Brasil possui normas para que produtos como os agrotóxicos e afins sejam autorizados e comercializados no País, é necessário que se obedeçam as diretrizes legais estabelecidos pelo decreto 4074/02 que regulamenta a lei 7802/89 e assim sejam avaliados em seus aspectos agronômicos, toxicológicos e ecotoxicológicos (Embarapa,2004).

Atualmente são cultivadas em Roraima, cerca de 600 hectares de melancias, sobretudo nos municípios de Bonfim, Normandia, Alto Alegre e de Mucajaí. Trata-se de uma das principais culturas do segmento da agricultura familiar do estado que propicia até mesmo a exportação dessa fruta para o estado do Amazonas (Embrapa,2007).

Este trabalho foi realizado como o objetivo de estudar o método QuEChERS para a determinação analítica de resíduos de agrotóxicos na melancia comercializada em Boa Vista - Roraima. Este método tem como vantagens ser rápido, fácil, econômico, efetivo, robusto e seguro (Anastassiades et al, 2003). Foi estudado o grupo dos carbamatos, sendo sua determinação efetuada na purificação das amostras através da extração em fase sólida dispersiva (d-SPE) que atualmente é uma das técnicas mais utilizadas para extração e ou concentração de amostras complexas, permitindo que os analitos em concentrações muito baixas sejam detectados por métodos como cromatografia líquida de alta eficiência(CLAE).

Nas amostras analisadas, embora sejam muito complexas, os sais sulfato de magnésio, cloreto de sódio, citrato de sódio tribásicodihidratado e citrato de sódio dibásico e o solvente escolhido que foi a acetonitrila, usados neste método permitiram uma ótima separação entre a água e os co-extrativos lipofílicos provenientes da amostra de melancia, proporcionou uma extração de uma ampla faixa de agrotóxicos investigados e em diferentes polaridades, mostrando como o método foi eficiente.

\section{FUNDAMENTAÇÃO TEÓRICA}

A procura dos agentes químicos apropriados para fins militares levou à síntese de numerosas substâncias dotadas de propriedades biocidas e portanto, passsíveis de uso contra plantas e animais nocivos (Carneiro et al ,2015).

Ferrer ( 1995 ), descreve alguns casos de intoxicação humana em grandes proporções, incluindo os que ocorreram por ingestão de alimentos contaminados. Essa contaminação pode ser decorrente do acúmulo de agrotóxico estáveis através da cadeia alimentar (como ocorre com os organoclorados), de uso excessivo de agrotóxicos no setor agrícola, sem a correta observação do período de carência, e da contaminação durante o transporte e armazenamento dos produtos.

Os carbamatos constituem o grupo mais versátil de pesticidas, podendo encontrar-se componentes deste tipo que funcionam como inseticidas, herbicidas, fungicidas e até anti-bacterianos (Tonlin,1994).

Ao contrário dos inseticidas organofosforados, os cabamatos foram desenvolvidos a partir de "produtos naturais". Em 1925 foi determinada a estrutura do principio ativo das sementes de Calabar (Physostigma venenosum), utilizadas em algumas tribos da África ocidental em "julgamento por prova", onde os suspeitos eram forçados a ingeri-as (Santos,2002).

A substância era um carbamato denominado "physostigmine" vulgarmente conhecido por eserina, também conhecido como fisostigmina, (Figura 1), é um parassimpaticomimético de ação indireta da inibição da acetilcolinesterase. Foi sintetizado em 1935 pelos químicos Percy Lavon Julian e Josef Pikl, após vários estudos da sua estrutura, foram sintetizados análogos como atividade, tanto no ponto de vista farmacêutico como do ponto de vista agro-químico (Santos,2002). 
Figura 1: Estrutura química da Serina

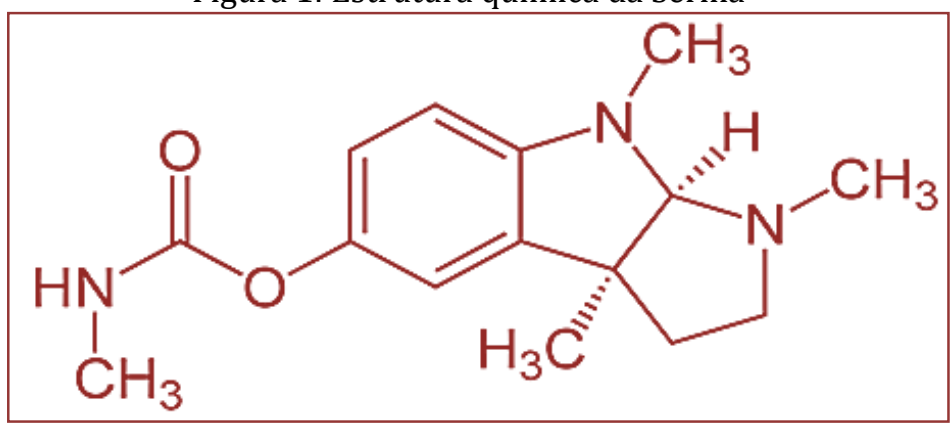

Fonte: EPA,2007

Mídio ; Silva, (1995), descrevem a preocupação sobre a poluição ambiental por inseticidas clorados não degradáveis no ambiente, onde tem levado ao uso dos carbamatos para várias finalidades: agricultura, pecuária, ambiente doméstico e em saúde pública. Este aumento deve-se à sua eficácia como inseticidas, assim como ao fato de que estes compostos não se acumulam na natureza e são de decomposição relativamente rápida após a aplicação. Embora ofereçam menor risco para o meio ambiente, o inseticida carbamatos é altamente tóxico para animais e humanos e as intoxicações provocadas por este composto têm aumentado, particularmente, nos países em desenvolvimento.

Foram desenvolvidos e usados em grande escala nos últimos quarenta anos e mais de cinquenta carbamatos são conhecidos (WHO, 1986). Apresentam alta eficiência praguicida, principalmente, atividade inseticida, baixa ação residual e baixa toxicidade em longo prazo, com amplo espectro de uso (Mídio ; Silva, 1995).

Atualmente, os carbamatos disponíveis no mercado são: Aldicarb (Temik ${ }^{\circledR}$ ), Aminocarb (Metacil ${ }^{\circledR}$ ), Carbaril (Sevin ${ }^{\circledR}$ ), Carbofuran (Carboran ${ }^{\circledR}$, Furadan ${ }^{\circledR}$ ), Landrin (Landrin ${ }^{\circledR}$ ), Metacalmato (Bux ${ }^{\circledR}$ ), Metiocarb (Mesurol ${ }^{\circledR}$ ), Metomil (Lannate ${ }^{\circledR}$, Nudrin ${ }^{\circledR}$ ), Mexacarbato (Zectran ${ }^{\circledR}$ ), Propoxur (Baygon ${ }^{\circledR}$, Unden ${ }^{\circledR}$ ).

De acordo com Moraes et al, 1996, as principais toxidades dos carbamatos são:

A inibição colinesterásica de curta duração; - Não penetram efetivamente no sistema nervoso centra(SNC), resultando toxicidade limitada; - Gravidade do quadro: usualmente leve a moderada; - 0 aldicarb tem alta toxicidade podendo levar a quadros severos e podem evoluir ao óbito em poucas horas.

Os carbamatos em geral e seus produtos de transformação são de natureza polar e termicamente lábeis; estas propriedades limitam o uso da técnica de cromatografia gasosa para a sua quantificação (Delgado et al.,2001). Por tanto a escolha do uso da Cromatografia Liquida de alta eficiência.

\section{JUSTIFICATIVA}

O Estado de Roraima tem aproximadamente 469524 habitantes, segundo a estimativa populacional de 2012, realizada pelo Instituto Brasileiro de Geografia e Estatística (IBGE) , em Boa Vista, capital, concentra $65,3 \%$ da população do estado, portanto ha uma necessidade de monitoração de alimentos produzidos para o consumo dessa população. A Anvisa coordena o Programa em conjunto com as Coordenações de Vigilância Sanitária dos estados da Federação envolvidos no PARA, os quais vêm realizando os procedimentos de coleta dos alimentos nos supermercados para posterior envio aos laboratórios. No ano de 2008, foram monitorados 24 estados da Federação e o estado de Roraima estava na relação, porém dentre as frutas monitoradas a melancia não foi selecionada, por isso à necessidade de monitoração dessa fruta que faz parte da mesa brasileira.

\section{OBJETIVOS}

Este trabalho teve por objetivo o desenvolvimento do método analítico Quechers que é rápido e eficiente para a determinação multiresídual de agrotóxicos em alimentos , empregando-se a cromatografia líquida de alta eficiência com detecção por arranjos de diodos. 


\subsection{OBJETIVO ESPECÍFICO}

- Determinar quais os pesticidas estão presente na cultura de melancia nos municípios de Bonfim e Normandia.

- Quantificar os pesticidas presente nesta cultura e comparar com o Limite Máximo de Resíduo (LMR) conforme a portaria 14/2011.

\section{MÉTODOLOGIA}

Durante o desenvolvimento do método , grande ênfase foi dada para obtenção de um procedimento dinâmico, que pudesse ser aplicado em qualquer laboratório, devido à simplificação das etapas como esta representado na figura 2 e de acordo com o fluxograma.

Figura 2: Extração de carbamos em amostras de melancia por CLAE.

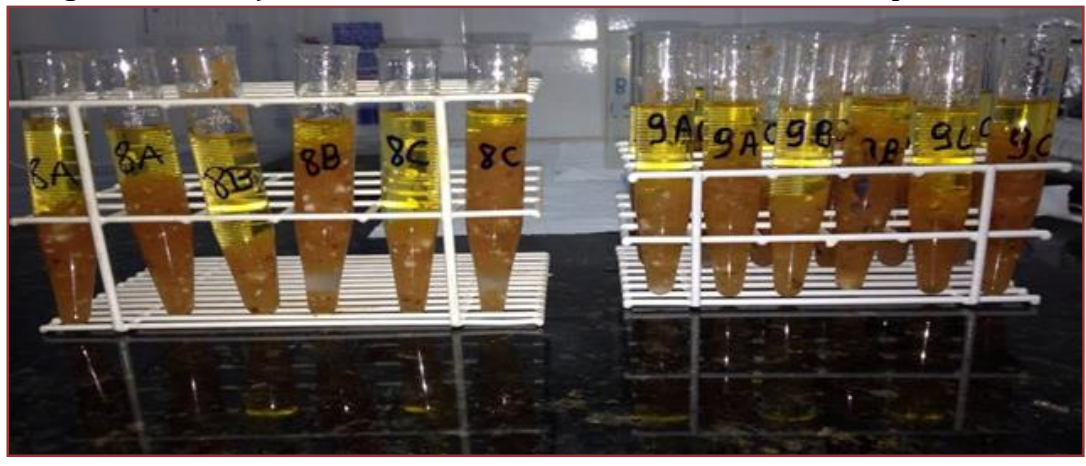

Figura 3: Fluxograma do procedimento da extração da amaostra.

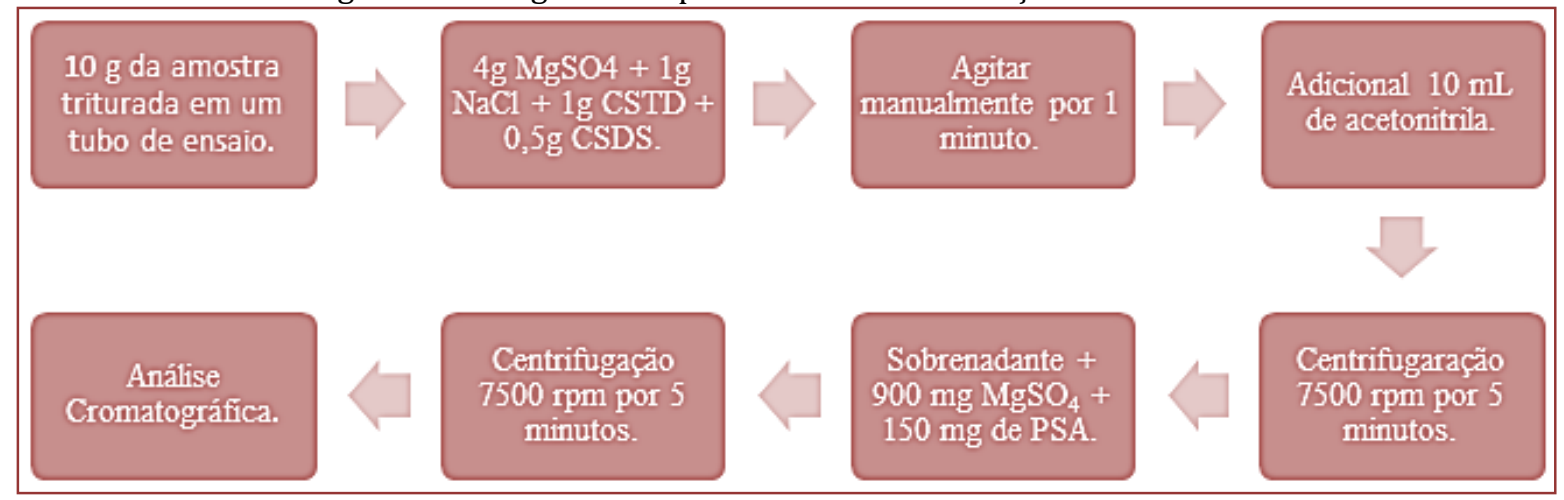

As etapas envolvidas neste método são: a extração com a acetonitrila - ACN seguida de partição, provocada pela adição dos sais (sulfato de magnésio - $\mathrm{MgSO}_{4}$ ), cloreto de sódio $(\mathrm{NaCl})$ e a limpeza da amostra com solventes como C18, PSA (amina primária/secundária) e carbono grafitado (usado em amostras com clorofila),(Anastassiades et al,2003).

As condições dos sais $\mathrm{MgSO}_{4}$ e $\mathrm{NaCl}$ são empregadas nesse método para induzir a fase de separação entre o conteúdo de água da amostra e a camada de ACN. Os sais de CSTD e CSBS tampona a amostra para estabilizar o pH. A ACN é miscível com a água e promove a extração em uma fase única quando em contato com a matriz (Bastos et al,2013). A utilização desses reagentes possibilita a extração de uma menor quantidade de coextrativos lipofílicos provenientes de amostras complexas como esta, como por exemplo, ceras, gorduras e pigmentos e proporciona a extração de uma ampla faixa de pesticidas com diferentes polaridades. A ACN quando acidificada permite recuperações satisfatórias de agrotóxicos que geralmente apresentam problemas de estabilidade. Uma outra grande vantagem é que a ACN é mais adequada para a cromatografia liquida. Sendo assim, foi escolhida como solvente de extração para o método estudado.

Etapa Clean-up: Esta etapa é essencial para promover robustez e confiabilidade aos resultados obtidos pelo sistema cromatográfico, uma vez que componentes não voláteis da matriz podem ficar aderidos no injetor e também na coluna cromatográfica, alterando a resposta do sistema e aumentando a frequência de manutenções necessárias. 
Apenas $1 \mathrm{~mL}$ do extrato foi colocado em contato com uma mistura contendo $150 \mathrm{mg}$ do solvente PSA e 900mg de $\mathrm{MgSO}_{4}$. Ao contrário dos métodos já existentes para esta etapa clean-up com o SPE que utilizam cartuchos ou colunas, a d-SPE permite que o clean-up e a redução de água residual sejam efetuados de uma forma rápida e simultânea. Pois a estrutura bidentada do PSA tem um elevado efeito quelante, devido à presença dos grupos amino primário e secundário. Como resultado, a retenção de ácidos graxos livres e de outros compostos polares presente nesta matriz que é muito forte.

\section{RESULTADOS E DISCURSÕES}

As determinações de multirresíduos mostram um meio efetivo de avaliar um grande número de agrotóxicos em um período de tempo relativamente curto. Por esse motivo,esse método foi escolhido pelo PARA onde investigou em 2013 uma grande variedade de legumes e frutas, o qual a melancia não fez parte, alguns resultados foram aprovados e outros não, como por exemplo, a presença do aldicarbe em algumas culturas. Neste estudo 100\% das amostram investigadas estão acima do LMR e ou, apresentam agrotóxicos proibidos de acordo com a legislação brasileira, a tabela 1 apresenta os resultados obtidos nas amostram em melancia cultiva e comercializada em Roraima.

Tabela 1: Resíduos de carbamatos encontrados nas amostras de melancia cultivadas e comercializadas em Boa Vista - RR. (A1 ao A10 , são as amostras e os P1 ao P11 são os pesticidas).

\begin{tabular}{|c|c|c|c|c|c|c|c|c|c|c|c|}
\hline & 1 & 2 & 3 & 4 & 5 & 6 & 7 & 8 & 9 & 10 & 11 \\
\hline 2 & 8 & D & $\mathrm{D}$ & D & D & D & D & 6 & 37, & 19, & D \\
\hline 3 & 6 & D & D & ,52 & D & D & D & 69, & ,52 & 36 & D \\
\hline 4 & ,7 & D & D & 7,6 & D & D & D & 09, & 65, & 38, & D \\
\hline 5 & 09, & D & D & D & ,56 & D & D & 74, & 53, & 28, & D \\
\hline 6 & 8, & D & D & ,52 & D & D & D & 84, & 13, & 37, & D \\
\hline 7 & 2 & D & 36 & ,85 & ,34 & D & D & ,62 & ,58 & ,34 & D \\
\hline 8 & 89, & D & D & D & ,44 & $\mathrm{D}$ & D & ,32 & 16, & 24 & D \\
\hline 9 & 45, & D & D & 012, & D & D & D & ,25 & 22 & 66 & D \\
\hline 10 & ,84 & D & D & 072, & 009, & D & D & 76, & 45, & 11, & D \\
\hline
\end{tabular}

Nas amostras A3, A5 e A9, em negrito, os LMRs estão abaixo do permitido para o carbamatometomil (P4) apenas, onde o valor máximo de resíduos em mg.kg-1 é igual a 1,0 autorizado pela ANVISA,2007, nas demais amostras o resíduos estão acima do permitido pela legislação vigente. E para os outros Países como a União Europeia e os Estados Unidos, também encontram-se acima do permitido. De acorodo com os resultados apresentados $100 \%$ das amostras investigadas por carbamatos estão acima do LMR e ou apresentam agrotóxicos proibidos pela legislação brasileira, nos quais foram determinados, conforme a tabela 1. Todas as amostras analisadas pelo método obteve resultados em níveis aceitáveis nas avaliações de desempenho do método.

A técnica empregada, CLAE, obteve bons resultados juntamente com o método. As amostras A3, A7 e A9 apresentaram um valor a baixo do LMR, apenas para o carbamatometomil(P4), porém as identificações dos carbamatos, aldicarbe(P1) , oxamil(P8), carbofurano(P9) e 1-Nafitol(P10), nessas mesmas amostras 
as classificaram como reprovada, já que o oxamil e o aldicarbe são proibidos pela legislação e as demais amostras estão acima do LMR permitido,das quais foram detectados os pesticidas, os outros não identificados (ND) foram:aldicarbesulfóxide, aldicarbesulfone, metomil, metiocarbe P2,P6,P7e P11,respectivamente. Ficando claro a necessidade de um programa de analise mais eficiente, dinâmico e habitual em relação aos cultivos de alimentos no Brasil, pois a falta desse procedimento pode levar as pessoas que manipulam os agrotóxicos a graves doenças.

\section{CONSIDERAÇÕES FINAIS}

A secretaria de defesa agropecuária, juntamente como Ministério da Agricultura, Pecuária e Abastecimento (MAPA), divulgou um relatório, no respectivo ano de estudo desse trabalho, sobre o qual apresenta sua competência e sua missão a de : "assegurar a sociedade das populações vegetais, a saúde de rebanhos de animais, a idoneidade dos insumos e dos serviços utilizados na agropecuária". Com toda sua competência, planejamento a fiscalização,o MAPA ainda deixa a desejar já que os resultados apresentados neste estudo, sobre as investigações de carbamatos em melancia, provenientes dos cultivos em questão estão fora do contexto.

Vale ressaltar que muitos trabalhos publicados, revelam a variedade de pesticidas em amostras de alimentos, em varias técnicas e métodos por todo o mundo, no Brasil muitos mostram a falha desse programa e alimentos contaminados por pesticidas, a quantificação dos carbamatos foram realizados com sucesso pelo método QuEChERs e pela cromatografia liquida de alta eficiência, todos os resultados foram comparados com os LMR dentro da legislação brasileira, por tanto percebemos a importância desses monitoramentos junto as instituições capacitadas para tal, pois estamos vulneráveis a esses alimentos contaminados por descuido e falta de mais investimento pelo Governo nas agricultura e pecuária de nosso País.

\section{REFERENCIAS}

[1] Anastassiades, M., Lehotay, S.J, Stajnbaer, D .; Schenck, f.j.fast e método multiresidue fácil empregando extração / partioning de acetonitrila e "extração em fase sólida dispersiva" para a determinação de resíduos de pesticidas em produtos. Jornal of aoac international, v.86, 2003. 412-4311p.

[2] Bastos,L.H.P;Gouvêia,A.V;Cardoso,M.H.W.M;Silva,R.S;Nóbrega,A.W;Jaco B,S.C. Uso da Espectrometria de Massa Sequencial Para Avaliar Resíduos de Agrotóxicos em Amostras de Alimentação Animal. Revista Analytica. v.64, 2013. $79-81 p$.

[3] Carneiro, Fernando Ferreira et al (Org.). Dossiê ABRASCO: um alerta sobre os impactos dos agrotóxicos na saúde. Rio de Janeiro: EPSJV; São Paulo,SP, 2015.45p.

[4] Delgado,C,Guilherme. Expanção e modernização do setor agropecuário no pós-guerra: Um estudo da reflexão agrária. Desenvolvimento Rural. São Paulo,SP,v,15,200. 43P.

[5] Embrapa Mandioca e Fruticultura Tropical. Agrotóxico no Brasil: processo de registro, risco à saúde e programa de monitoramento. ed.21,2004.

[6] Embrapa. Insetos-pragas associados à Cultura de melancia em Roraima, Alternativa e controle, ed.6,2007.

[7] Ferrer,A;Cabral,R. Recent epidemics of poisoningby pesticides. Toxicology lettes. v,83.1995. 55p.

[8] Mídio,A;Silva,E,S. Inseticidas-acaricidas organofosoforados e carbamatos. São Paulo,SP,1995.

[9] Peres, F. É veneno ou é remédio? Os desafios da comunicação rural sobre agrotóxicos, Dissertação (Mestrado em Saúde Pública) - Universidade Estadual do Rio de Janeiro,Rio de Janeiro, RJ, 1999.

[10] Santos,S,Pina. A química da inseticidas (parte1), Lisboa, 2002.43p.

[11] Tomlin,C. The pesticide manual, incorporating the agrochemicais handbook. Reino Unido. Britich hop protection,1994. 


\section{Capítulo 4}

Sedimentação contínua do polvilho doce na presença de coagulante a base de moringa oleifera lam

\section{Amarílis Severino e Souza}

Kássia Graciele dos Santos

Resumo: 0 polvilho doce possui diversas aplicações tanto no setor de alimentos quanto na indústria de tecidos, papéis, colas, embalagens biodegradáveis. Durante a fabricação de polvilho em indústrias de pequeno e médio porte, as raízes de mandioca são descascadas, raladas e depois seguem para a lavagem de modo a separar a fécula do bagaço. 0 polvilho é obtido após decantação da água de lavagem, seguida pela secagem da massa concentrada. Como as partículas de polvilho são muito finas e de baixa densidade, o seu tempo de sedimentação é elevado, o que resulta numa operação cuja batelada dura de 18 a 24 horas. Assim, torna-se interessante o estudo de coagulantes que agreguem as finas partículas de polvilho, formando conjuntos maiores e mais pesados que sedimentam com maior velocidade. Neste contexto, o objetivo deste trabalho foi diminuir o tempo de sedimentação do polvilho doce por meio da adição do coagulante natural extraído da semente de M. oleifera, de modo a tornar viável a operação contínua dessa etapa de separação. Foi avaliado o efeito da concentração de polvilho e da dosagem de coagulante sobre a velocidade de sedimentação em testes de proveta, por meio de um planejamento fatorial. Utilizando os valores adequados de ambas variáveis e as condições experimentais calculadas por meio do método de Kynch, foi construída e operada uma unidade experimental de sedimentação contínua. Observou-se que a adição do coagulante aumentou consideravelmente a velocidade de sedimentação, reduzindo o tempo de sedimentação batelada em cerca de $80 \%$. Nos testes de sedimentação contínua, foi obtido um clarificado com baixa concentração de sólidos, aproximadamente $0,4 \mathrm{~g} / \mathrm{L}$, e uma concentração de lama próxima ao valor de projeto de $600 \mathrm{~g} / \mathrm{L}$. No entanto, como as suspensões do espessado de polvilho, com alta concentração de sólidos, apresentaram resistência ao escoamento quando submetidas a um aumento de tensão, é recomendável que a retirada de lama do sedimentador contínuo seja feita com auxílio de bombas do tipo parafuso ou rosca sem fim.

Palavras-chave: Coagulante natural. Fécula de mandioca. Teste de proveta. 


\section{INTRODUÇÃO}

São conhecidas as diversas aplicações culinárias e industriais do polvilho doce. Na área alimentícia, o polvilho é utilizado na fabricação de bolos, biscoitos, pães de queijo, quitandas em geral, sendo também utilizado em frigoríficos para absorver água e deixar os produtos mais macios; em massas, como flavorizante e para diminuição do tempo de cozimento e em produtos especiais sem glúten, que atualmente têm ganhado boa aceitação pelo mercado (Revista Aditivos e Ingredientes, 2009).

0 processamento da raiz da mandioca para obtenção do polvilho em pequenas e médias indústrias possui algumas etapas fundamentais. Ao chegar na indústria, a mandioca é lavada para a remoção de impurezas e descascada. A casca fina é removida, mantendo-se a casca grossa por conter alto teor de amido. Em seguida, a mandioca é ralada em partes finas, a fim de aumentar o rendimento da matéria prima. A extração do amido de mandioca é feita em tanques equipados com agitadores e peneiras, nos quais água é adicionada à mandioca ralada e são separados o bagaço e o bagacilho. A suspensão resultante de aparência leitosa contendo o amido é distribuída para tanques de decantação. A massa decantada é em seguida submetida à secagem ao sol para obtenção do polvilho doce ou deixada fermentando por cerca de 15 dias para produzir o polvilho azedo. 0 produto é então classificado, embalado em plástico ou papel e armazenado em local seco e ventilado para que não haja modificação nas suas características (Matsuura et al., 2003).

O tempo total da etapa de decantação em um processo de produção de polvilho doce varia de 18 a 24 horas por batelada (Souza; Bragança, 2000). É desejado um menor consumo de tempo nessa etapa, visto que o processamento da mandioca deve ser feito no prazo máximo de 36 horas após a colheita, caso contrário, podem acontecer perdas e escurecimento da matéria prima devido à ação de enzimas sobre as substâncias tânicas nela presentes, o que resulta em produtos de qualidade inferior (LIMA, 1982). Além disso um menor tempo de sedimentação poderia viabilizar um processamento contínuo, aumentando a produção por unidade de tempo.

A sedimentação de uma suspensão aquosa de partículas ou flocos pode sofrer influência de fatores como a natureza das partículas, seu tamanho, forma, densidade e a concentração de sólidos em suspensão. Um dos principais fatores que causam o alto tempo de sedimentação do polvilho é o tamanho de suas partículas que, de acordo com Daiuto et al (2002), variam de 8 a $22 \mu \mathrm{m}$. Por serem muito finas e de baixa densidade, sua velocidade terminal é baixa, implicando em altos tempos de retenção no decantador. Assim, torna-se interessante o estudo de coagulantes que agreguem as finas partículas de polvilho, formando conjuntos maiores e mais pesados, de modo que se diminua o tempo de sedimentação envolvido.

A Moringa oleifera é uma leguminosa de porte arbustivo cuja semente tem sido estudada para uso como coagulante natural. A atividade das sementes de M. oleifera se deve à presença de proteínas catiônicas solúveis em água, densamente carregadas, que praticamente não afetam o $\mathrm{pH}$ e a condutividade do meio (Ndabigengesere; NARASIAH; TALBOT, 1995). 0 extrato das sementes foi estudado para tratamento de água e efluentes por Pritchard et al. (2010) e Schmitt (2011), que apontaram o elevado percentual de remoção de turbidez e potencial coagulante do extrato das sementes.

Sendo assim, o objetivo deste trabalho foi diminuir o tempo de sedimentação do polvilho doce por meio da adição do coagulante extraído da semente de M. oleifera, de modo a tornar viável a operação contínua dessa etapa de separação. Para tal, foi feito um planejamento experimental no qual foi analisado o efeito da dosagem de coagulante e da concentração de polvilho sobre o tempo de sedimentação em testes de proveta. Após a seleção da melhor condição batelada de sedimentação, uma unidade de sedimentação contínua, por meio de um dos métodos tradicionais de projeto de sedimentadores (Método de Kynch).

\section{REVISÃO BIBLIOGRÁFICA}

Será feita a caracterização do polvilho doce e a descrição de seu processo de produção nas indústrias. É dado enfoque à etapa de sedimentação do polvilho, assim, serão apresentados trabalhos científicos relevantes no que diz respeito a essa operação unitária, abordando, inclusive, conceitos referentes à coagulação e ao uso de coagulantes.

\subsection{POLVILHO DOCE}

De acordo com a Resolução da Comissão Nacional de Normas e Padrões para Alimentos (CNNPA) n 12 da Agência Nacional de Vigilância Sanitária (ANVISA), o amido é o produto amiláceo extraído das partes 
aéreas comestíveis dos vegetais, como as sementes. Fécula é o produto amiláceo extraído das partes subterrâneas comestíveis dos vegetais (tubérculos, raízes e rizomas). Assim, o produto amiláceo derivado da raiz da mandioca é denominado de fécula de mandioca, popularmente conhecido como polvilho doce.

A ANVISA não faz distinção entre as denominações fécula de mandioca ou polvilho doce, contudo, há uma diferenciação feita com base no processo produtivo e no nível de industrialização pelo qual a mandioca é submetida. Quando em produções de larga escala, nas quais a separação entre a água de lavagem e a fécula é feita por meio de centrífugas, filtros de tambor rotativo e a secagem feita por secadores, dá-se o nome de fécula de mandioca ao produto final. O polvilho doce, por sua vez, é produzido em unidades de pequeno e médio porte, em que a etapa de separação é realizada por meio da decantação e a secagem é solar. Neste trabalho, a denominação utilizada será polvilho doce ou fécula de mandioca, independente da forma de processamento.

A composição do polvilho doce pode variar devido a fatores como a qualidade da mandioca processada e as etapas de produção industrial. Os valores dos principais componentes e propriedades físico-químicas constam na Tabela 1.

O polvilho é principalmente constituído por carboidratos, com baixa quantidade de proteínas e $\mathrm{pH}$ ligeiramente ácido. Não contém glúten em sua composição, sendo uma alternativa para receitas e no mercado de produtos para celíacos.

As indústrias produtoras de polvilho doce estão concentradas no sul do Brasil, no estado do Paraná. Segundo o Centro de Estudos Avançados em Economia Aplicada (CEPEA), a tonelada de fécula de mandioca ou polvilho doce é vendida por valores que variam de $\mathrm{R} \$ 2060,71$ a $\mathrm{R} \$ 2231,38$ (CEPEA, 2016.)

Tabela 1 - Valores médios da caracterização físico-química da fécula de mandioca

\begin{tabular}{|c|c|}
\hline Variáveis & $\begin{array}{l}\text { Valores médios para o polvilho } \\
\text { doce }(\mathrm{g} / 100 \mathrm{~g})\end{array}$ \\
\hline Umidade inicial & 13,75 \\
\hline Carboidratos totais & 97,97 \\
\hline Açúcares solúveis & 1,31 \\
\hline Amido & 96,66 \\
\hline Fibras & 0,57 \\
\hline Cinzas & 0,50 \\
\hline Proteínas & 0,05 \\
\hline Matéria graxa & 0,005 \\
\hline $\mathrm{Ph}$ & 6,37 \\
\hline
\end{tabular}

\subsection{PROCESSO DE PRODUÇÃO DO POLVILHO DOCE}

As etapas que constituem a produção do polvilho doce são a colheita da mandioca, seguida por sua lavagem e descascamento, ralação ou moagem das suas raízes, lavagem e decantação da massa, secagem e posterior classificação e armazenamento. A Figura 1 esquematiza o processo geral de produção do polvilho doce. 
Figura 1 - Etapas do processo de produção do polvilho doce

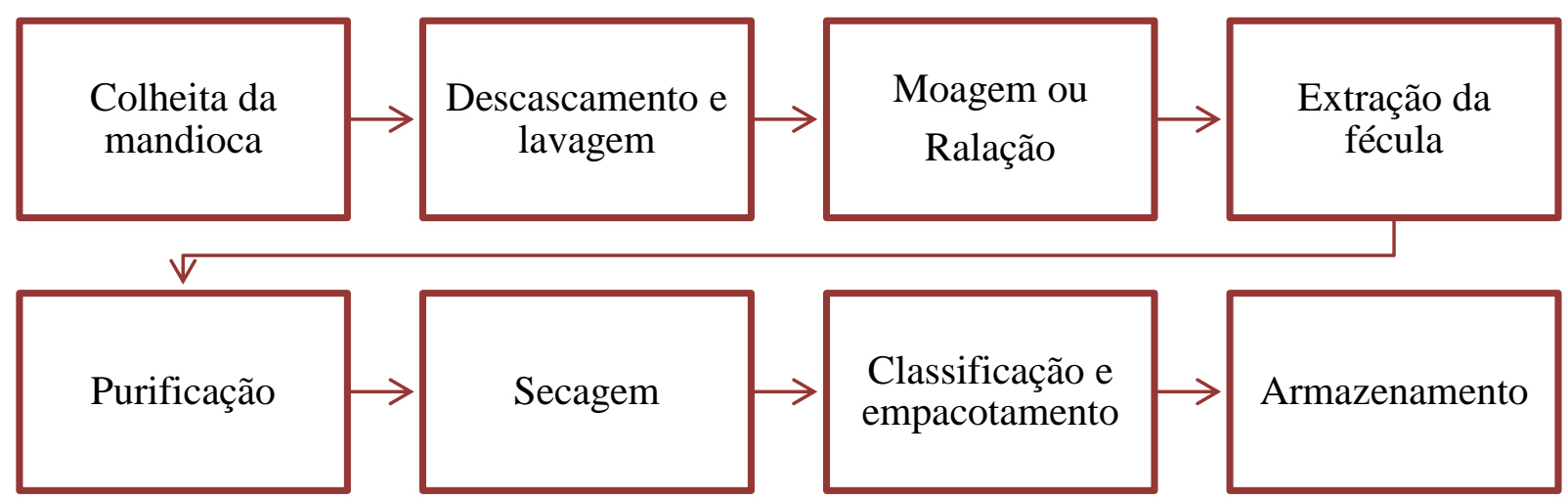

As indústrias de grande porte que fazem a extração da fécula são denominadas fecularias. Na produção em indústrias de pequeno e médio porte, o polvilho é produzido utilizando as mesmas etapas de produção que as fecularias, embora envolva equipamentos e formas de processamento que transformem menor quantidade de matéria-prima. As operações de colheita e transporte das raízes da mandioca são realizadas da mesma maneira, independente do porte da indústria.

\subsubsection{INDÚSTRIAS DE PEQUENO E MÉDIO PORTE}

As raízes de mandioca para fabricação de polvilho são colhidas com 16 a 20 meses de idade. Logo após a colheita inicia-se o seu processo de fermentação, portanto, o processamento das raízes deve acontecer no prazo máximo de $36 \mathrm{~h}$ para evitar que haja perdas, escurecimento ou que resulte na fabricação de produtos de qualidade inferior (REVISTA ADITIVOS E INGREDIENTES, 2010). Embora a mecanização do plantio seja uma realidade, a colheita mecanizada ainda está distante. Para facilitar a colheita são usados afofadores e subsoladores, mas o recolhimento das raízes ainda é feito manualmente (CEREDA, 2005).

Após sua lavagem e descascamento, as raízes da mandioca são raladas e a massa resultante é encaminhada para a extração. A extração manual da fécula é feita adicionando água à massa e filtrando a suspensão em tecidos de malha fina ou peneiras com tela de nylon (220\# Mesh). A lavagem é feita até que a água não apresente mais aspecto leitoso (CEREDA, 2014).

O líquido leitoso resultante da etapa de extração é conduzido a tanques de decantação, em cujo fundo a fécula é depositada e concentrada após um período de 18 a $24 \mathrm{~h}$. Encerra-se a batelada do polvilho doce drenando o líquido sobrenadante. Pode haver raspagem das impurezas concentradas na superfície da camada de polvilho seguida por adição de água e nova sedimentação a fim de obter um produto mais puro, livre de cascas e fibras (CEREDA, 2014).

Para produzir o polvilho azedo, a fécula é deixada nos tanques de decantação à temperatura ambiente por um período de 15 a 40 dias até que o produto atinja acidez aproximada de $5 \%$. Durante todo o período de fermentação, o polvilho deve permanecer coberto por uma lâmina de água de $10 \mathrm{~cm}$ e sua exposição ao ar deve ser evitada, pois provoca mudanças em sua coloração e redução na qualidade (REVISTA ADITIVOS E INGREDIENTES, 2010).

0 polvilho é levado para a secagem direta ao sol sobre peneiras forradas com panos de algodão. Após atingir uma umidade entre 13 e $14 \%$, ele é esfarelado e peneirado para posterior acondicionamento e armazenagem em local seco e arejado (SOUZA; BRAGANÇA, 2000).

Após a colheita e transporte da mandioca, as fecularias avaliam o teor de fécula nas raízes por meio da balança hidrostática, embora ela ofereça resultados imprecisos em relação a esse teor em algumas estações do ano. Mesmo que no Sudeste Brasileiro, o maior teor de matéria seca ocorra no período do outono e inverno pelo fato de o clima ser mais seco e frio, as fecularias processam durante todo o ano de modo a cobrir os custos fixos (CEREDA, 2005). É preciso um perfeito entrosamento entre as operações de colheita, transporte e industrialização das raízes para a obtenção contínua de um produto final uniforme (LIMA, 1982).

No processamento artesanal, as operações de descascamento e lavagem são realizadas separadamente. Nas fecularias, ambas etapas são realizadas no mesmo equipamento. Segundo Lima (1982) apud Cereda 
(2005), os descascadores/lavadores podem ser semicilíndricos, com processamento contínuo. Nesse equipamento, um tubo asperge água sobre as raízes, efetuando a lavagem e auxiliando a eliminação da película. Estima-se que são usados de 2 a $3 \mathrm{~m}^{3}$ de água para cada tonelada de raízes.

A etapa de ralação é destinada a romper os tecidos da raiz da mandioca para facilitar a liberação dos grânulos de fécula. Nas fecularias, a ralação é feita adicionando água ao ralador, que opera a $1000 \mathrm{rpm}$. A finura da massa ralada depende do tamanho dos dentes das lâminas serreadas. Para garantir a eficiência desejada no processo, são realizadas duas ralações. A segunda ralação, feita após peneiração da massa, melhora o rendimento em fécula, aumentando-o de $1 \%$ a $2 \%$ (LIMA, 1982).

Dos raladores, a massa ralada vai para uma sequência de peneiras cônicas rotativas (GLs), com abertura que diminui gradativamente. Essas peneiras separam a suspensão contendo fécula e água do bagaço ou farelo. Segundo Lima (1982), a massa ralada é enviada por bombas para peneiras onde a fécula é separada. Em pequenas fecularias, são utilizadas peneiras vibratórias providas de malhas muito finas, realizando em cada estágio uma lavagem e separação da fécula, que é então armazenada em tanque agitador ou tanque pulmão. Porém, o sistema de separação mais comum é constituído por baterias de extratores providos de peneiras cônicas horizontais, com crivos de $125 \mathrm{~mm}$, que giram em alta velocidade.

A massa de raízes raladas, suspensa em água, é introduzida na peneira através de um tubo central localizado no fundo do cone. Por causa da injeção contínua e do rápido movimento rotativo das peneiras côncavas, a massa desloca-se do fundo para fora. Ao mesmo tempo em que a força centrífuga age sobre a massa ralada, uma forte injeção de água lava a massa intensamente. 0 leite de fécula e a massa ralada lavada são retirados tangencialmente em relação ao eixo da peneira. A massa segue por vários outros extratores dispostos em série, a fim de retirar toda a fécula nela contida.

O leite extraído é levado a um tanque agitador, de onde é encaminhado à purificação pra ser concentrado de $3^{\circ}$ para $40^{\circ}$ Baumé (Bé) por meio de, no mínimo, duas centrífugas. Entre elas, pode existir um hidrociclone, para separar areia, e um filtro.

Nas fecularias o processo é contínuo e a etapa de purificação é feita em centrífugas de pratos a 1000 rpm, seguida de passagem da massa por um filtro de tambor rotativo. Nas centrífugas, o leite é concentrado para $22^{\circ}$ a $25^{\circ}$ Bé. Encaminhada para o tambor, a fécula sai do equipamento com $45 \%$ de umidade 0 rendimento das fecularias é de cerca de $250 \mathrm{~kg}$ de fécula por tonelada de raiz de mandioca (CEREDA, 2014).

A água que sai das centrífugas é reaproveitada na lavagem das raízes, levando a uma economia de $20 \%$ do total. Nas fecularias modernas, já não ocorre arraste da fécula nessa água (LIMA, 1982).

A fécula que sai do filtro a vácuo é esfarelada pelo próprio raspador afixado no filtro para recolher a torta, que segue para um secador pneumático. No secador, a fécula recebe ar em corrente paralela, proveniente de sopradores e aquecido por radiadores a $100-110{ }^{\circ} \mathrm{C}$ ou mais. A fécula é recuperada em ciclones, que abastecem a moega do dispositivo de ensacamento. Nesse sistema de secagem, a fécula é recolhida em pó muito fino, não necessitando de moagem posterior e, normalmente, obedece às exigências dos importadores quanto à granulometria (LIMA, 1982).

A Figura 2 ilustra as etapas da produção do polvilho doce explicitando as características de densidade e concentração aproximada da suspensão de fécula.

Figura 2 - Densidades e concentrações da suspensão de fécula nas etapas subsequentes à extração.

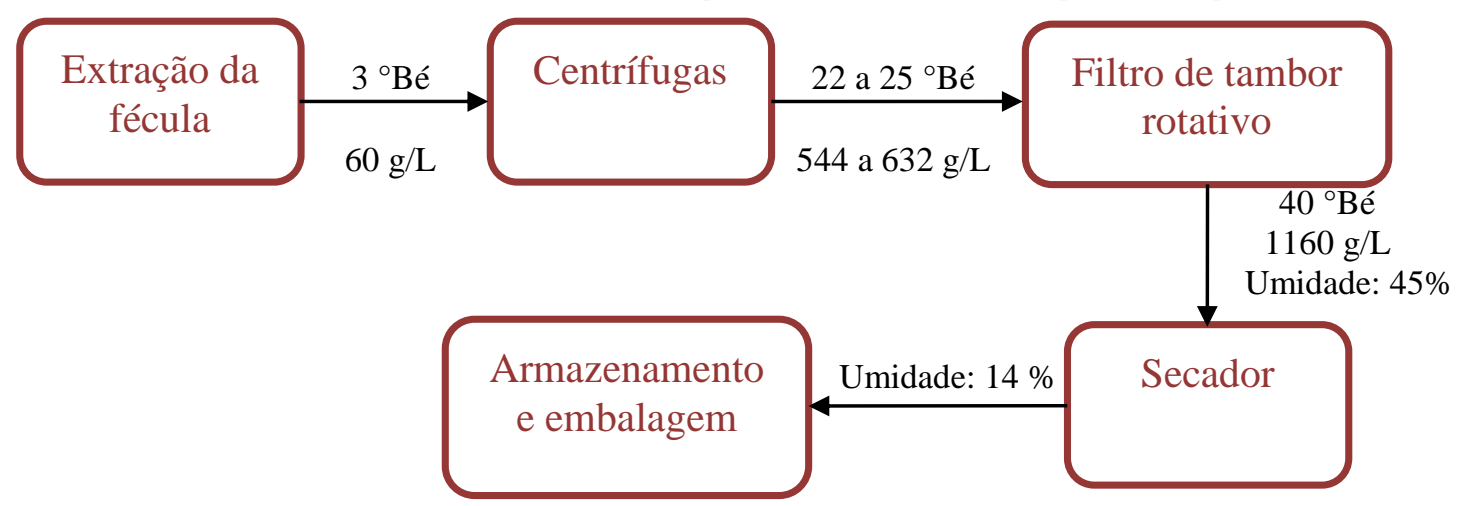


Devido ao alto custo das centrífugas e dos filtros de tambor rotativo a vácuo, o aprimoramento de métodos alternativos de purificação usando equipamentos mais baratos aumentaria a capacidade de produção nas indústrias de pequeno e médio porte e, portanto, diminuiria o custo final do produto. A sedimentação realiza a separação sólido-líquido pela ação do campo gravitacional, oferecendo à etapa de purificação do processo características de baixo custo variável, além de simplicidade operacional.

\subsection{SEDIMENTAÇÃO}

A sedimentação é uma operação de separação sólido-líquido baseada na diferença de densidade entre as fases presentes na suspensão a ser processada e na ação do campo gravitacional.

É comum classificar os sedimentadores em dois tipos: os espessadores, que têm como produto de interesse a fase particulada e são caracterizados pela produção de lama ou lodo com alta concentração de partículas; e os clarificadores, que têm como produto de interesse o líquido clarificado com baixa concentração de sólidos (AROUCA, 2007).

As contribuições para o estudo da sedimentação têm registro desde o começo do século XX, com estudos que se aprofundam até dias de hoje. Nos primeiros anos, foram avaliados principalmente os parâmetros e variáveis que influenciam no processo. Os estudos continuaram com destaque na área de dimensionamento e projeto de tanques sedimentadores, chegando até pesquisas mais recentes envolvendo testes experimentais e, principalmente, simulação de modelos computacionais que descrevem essa operação unitária.

\subsection{COAGULAÇÃo}

A coagulação é um processo que desestabiliza uma dispersão coloidal por meio da adição de produto químico apropriado, fazendo com que haja redução das forças de repulsão entre as partículas com cargas negativas, o que provoca a aglutinação e precipitação da fase dispersa. A etapa de coagulação é realizada em tanque com agitação intensa para facilitar a mistura entre coagulante e partícula e aumentar a frequência de choques (PAVANELLI, 2001).

A coagulação está associada à redução do potencial zeta, que se refere ao potencial elétrico entre a superfície da camada compacta formada ao redor da partícula e o meio líquido em que está inserida. Esse potencial é reduzido a valores que permitam a posterior aglutinação de partículas (floculação), que é conduzida em um tanque com agitação lenta para que, durante a aglutinação, não ocorra a eclosão dos aglomerados ou quebra dos flocos (CREMASCO, 2012).

Segundo Vaz (2001) apud Schmitt (2011), o mecanismo de coagulação/floculação é dependente de diversos fatores, dentre eles o tipo e dosagem de coagulante, $\mathrm{pH}$ do meio, natureza das partículas a serem agregadas. 0 tipo e a dosagem ideal da quantidade de coagulante são definidos em função da viabilidade econômica e das características do efluente. Por essa razão, testes de coagulação são executados para determinar as dosagens mais adequadas para a operação de separação envolvida.

Os coagulantes podem ser divididos em duas classes, a de coagulantes químicos (inorgânicos) e a de coagulantes naturais (orgânicos). Os coagulantes químicos são normalmente sais de ferro e alumínio e polímeros sintéticos, muito utilizados no tratamento de água e esgoto. Possuem desvantagens relacionadas ao aumento da concentração de metais na água, o que pode ocasionar problemas à saúde humana, produção de grande volume de lodo tóxico, já que o alumínio e o ferro não são biodegradáveis, e o consumo de alcalinidade do meio, o que ocasiona maiores custos com produtos utilizados para correção do pH (SCHMITT, 2011). Os coagulantes naturais ou biopolímeros são biodegradáveis e não produzem nenhuma poluição secundária que ocasione problemas de saúde. Podem ter várias aplicações que incluem seu uso em alimentos e até em processos de tratamento de águas residuárias e de abastecimento. Esse tipo de coagulante geralmente é proveniente de partes de plantas, como folhas, cascas e sementes. oleifera.

Um dos coagulantes naturais que tem sido bastante estudado é o extrato da semente de Moringa

\subsubsection{MORINGA OLEIFERA}

A Moringa oleifera é uma planta de porte arbustivo nativa do norte da Índia, atualmente encontrada em vários países dos trópicos, de crescimento rápido e com desenvolvimento em climas úmidos ou quentes, 
podendo sobreviver em solos pouco férteis e secos. (ANWAR et al., 2007). Pode produzir cerca de 2000 sementes por ano, mas, conforme a forma de cultivo feita, esse número pode ser de cinco a dez vezes maior. As vagens da M. oleifera contêm as sementes, cuja massa varia entre 150 e 300 mg (JAHN, 1989). A Figura 3 apresenta fotografias das vagens e das sementes com e sem casca de M. oleifera.

Figura 3 - Fotografias de M. oleífera: (a) vagens; (b) sementes; (c) miolos das sementes

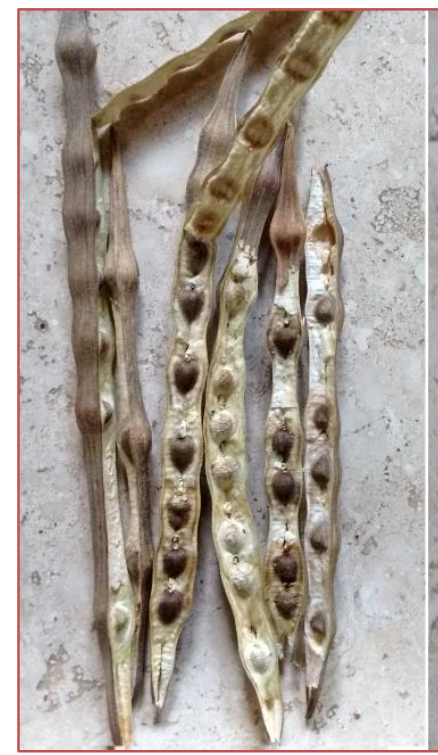

(a)

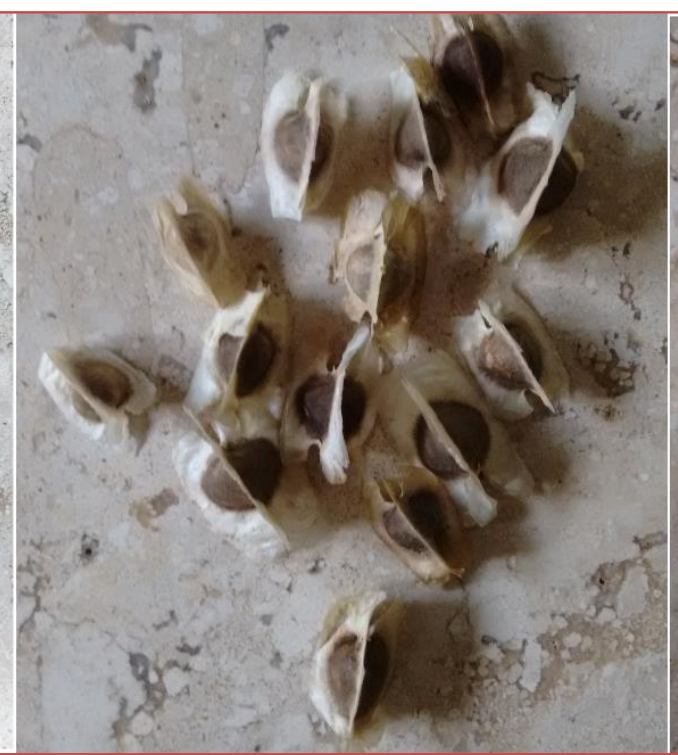

(b)

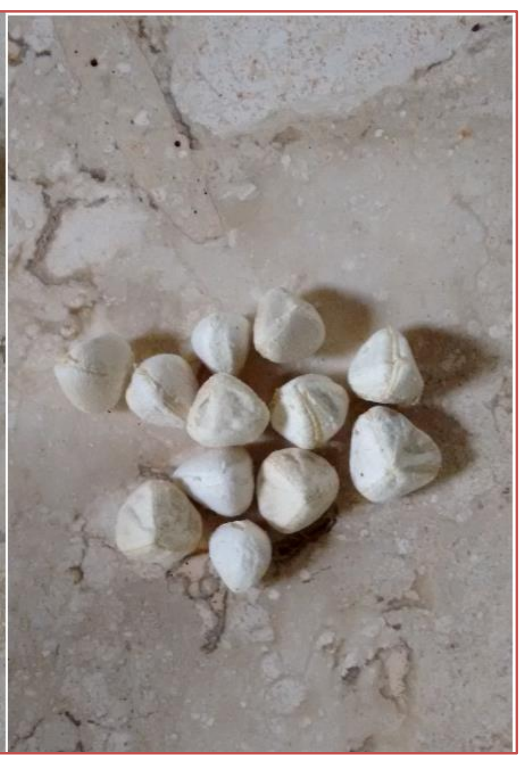

(c)

Fonte: Do autor, 2015.

Ndabigengesere, Talbot e Narasiah (1995) estudaram a eficiência no tratamento de água e propriedades da M. oleifera como coagulante natural em comparação ao sulfato de alumínio. Foi utilizado um zetâmetro para determinar o mecanismo de coagulação do agente coagulante do extrato, já que esse mecanismo depende das forças eletrostáticas entre cargas existentes entre as partículas coloidais. Os autores afirmam que os agentes ativos no extrato da planta são proteínas catiônicas diméricas de peso molecular igual a 13 kDa e o mecanismo de coagulação com M. oleifera consiste na adsorção e neutralização de cargas coloidais. Ainda complementam que a planta é não-tóxica, biodegradável e que não afeta significativamente o pH e condutividade da água após o tratamento.

De acordo com Mendes (1989) apud Pavanelli (2001), os mecanismos de coagulação por adsorção e formação de pontes acontece quando são utilizados como coagulantes os compostos orgânicos (polímeros) sintéticos ou naturais. Eles podem apresentar sítios ionizáveis ao longo de suas cadeias, podendo ser classificados como catiônicos, aniônicos e anfóteros. Nesse mecanismo, o coagulante adsorve na superfície das partículas coloidais, reduzindo a carga existente ou entrelaçando as partículas nas cadeias do polímero.

Apesar deste trabalho envolver a aplicação da semente de M. oleifera como coagulante em uma etapa da produção do polvilho doce, a maioria dos estudos publicados refere-se à sua utilização no tratamento de água e efluentes. Nos trabalhos a serem apresentados em seguida, será dado maior enfoque nos parâmetros e condições de operação empregados pelos autores para otimizar o uso do coagulante.

Muyibi e Evison (1994) estudaram a purificação de águas duras utilizando as sementes de M. oleifera. Afirmaram que o mecanismo envolvido na remoção da dureza da água pela metodologia utilizada era a adsorção. Assim, quando uma maior quantidade de espécies que causam o endurecimento da água estava presente na amostra, era necessária a aplicação de uma maior dosagem. Os autores afirmam que o extrato de M. oleifera aparenta ter capacidade de natural tamponamento e que a eficiência da purificação de águas duras utilizando esse extrato foi independente do $\mathrm{pH}$ e alcalinidade.

Ndabigengesere e Narasiah (1998) avaliaram a qualidade da água tratada pelo extrato de M. oleifera comparado a água tratada com sulfato de alumínio. Sementes com e sem casca foram utilizadas e os testes foram conduzidos em águas sintéticas e jar test. Podem ser usadas como coagulante as sementes com ou 
sem casca, embora as sementes sem casca sejam mais eficientes. A análise da água tratada mostrou que as sementes de M. oleifera não afetam significativamente o pH, condutividade, alcalinidade e concentração de cátions e ânions no meio, exceto para ortofosfatos e nitratos, que têm sua concentração aumentada. Comparadas ao sulfato de alumínio, as sementes não precisam de ajustes no pH e não resultam em problemas com corrosão.

Béltran-Heredia e Sánchez-Martín (2009) avaliaram a capacidade do extrato de M. oleifera para remover o lauriléter sulfato de sódio. Os autores concluíram que o extrato age como um removedor de surfactantes aniônicos, atingindo 80\% de eliminação. Dois dos parâmetros avaliados foram pH e temperatura. Com o aumento do $\mathrm{pH}$, a eficiência do processo diminuiu devido ao caráter catiônico da proteína da M. oleifera responsável pela coagulação. A temperatura não afetou significativamente o processo de remoção de surfactante.

Pritchard et al. (2010) investigaram os parâmetros que afetam a eficiência do uso da M. oleifera no tratamento de água potável, demonstrando os efeitos de vários parâmetros de qualidade de água na performance das sementes. 0 estudo revelou que o método mais adequado de dosagem consistia em agitar o pó das sementes em uma pasta concentrada, formando um suspensão estoque. Utilizando uma dosagem de coagulante de 50 mg.L-1 em amostras de água de turbidez fixa em 130 NTU e variando o pH de 4 a 9, descobriram ainda que a performance do coagulante na remoção de turbidez não era sensível a variações no $\mathrm{pH}$. A partir de testes executados na faixa de temperatura 4 a $60{ }^{\circ} \mathrm{C}$, descobriram que quanto maior a temperatura, mais efetiva era a coagulação.

Schimitt (2011) estudou a eficiência de técnicas de tratamento de efluente de laticínios baseadas nos princípio de coagulação utilizando o coagulante extraído da semente de M. oleífera. Dentre as técnicas avaliadas pela autora, os melhores resultados foram obtidos com a combinação de coagulação/floculação seguida de sedimentação por 60 min utilizando 1500 ppm de pó das sementes, finalizando o tratamento por ultrafiltração. A sequência de técnicas alcançou uma remoção de 99,9\% de cor aparente e turbidez e 98,5\% de DQO, sendo o coagulante de M. oleífera apontado como promissor para o tratamento de águas residuárias da indústria de laticínios.

Coldebella et al. (2013) avaliaram nove diferentes métodos de preparação do coagulante das sementes de M. oleifera na remoção da turbidez e cor aparente de águas superficiais. Para os parâmetros de qualidade avaliados, os métodos que apresentaram maior porcentagem de remoção foram os que usaram o pó integral da semente, a solução integral (salina) e a solução desengordurada (salina). Para água superficial com turbidez inicial próxima a 70 NTU, a eficiência de remoção foi cerca de $80 \%$ para cor aparente e $85 \%$ para turbidez para os três métodos de preparo apontados como mais eficientes.

\section{METODOLOGIA}

Foi feita uma avaliação inicial do extrato das sementes de Moringa oleifera a fim de verificar o seu potencial como coagulante na etapa de sedimentação do polvilho doce em testes de proveta, analisando o efeito das principais variáveis envolvidas. Em seguida, foi feita análise do comportamento reológico da suspensão de polvilho doce. Finalmente, foram realizados ensaios de sedimentação contínua em aparato experimental utilizando as condições operacionais obtidas na parte de avaliação, observando a eficiência da adição de coagulante no processo.

\subsection{TESTES DE PROVETA}

A determinação do tempo de sedimentação do polvilho foi feita por meio de testes de proveta, nos quais foram adicionadas quantidades variadas e controladas de extrato de M. oleifera (EMO). A influência da dosagem de EMO, como também a concentração de polvilho sobre esse tempo foram avaliadas por métodos estatísticos.

\subsubsection{PREPARAÇÃO DO EXTRATO}

Para a preparação do extrato, foi utilizada metodologia adaptada de Pritchard et al (2010). Vagens de M. oleifera foram coletadas no Instituto Federal do Triângulo Mineiro (IFTM), campus Uberaba.

As sementes foram descascadas manualmente e em seguida o seu miolo foi triturado até formar um pó fino, que foi separado numa peneira com malha de $1 \mathrm{~mm}$ de abertura. Uma massa de $4 \mathrm{~g}$ do pó peneirado 
(dp $<1 \mathrm{~mm}$ ) foi agitada com $200 \mathrm{~mL}$ de água destilada durante $30 \mathrm{~min}$ em um agitador magnético, mantendo a temperatura de $24{ }^{\circ} \mathrm{C}$. A suspensão foi deixada em repouso por 10 min e o líquido sobrenadante foi coletado e utilizado para as dosagens de coagulante.

De modo a evitar possíveis mudanças na viscosidade, $\mathrm{pH}$ ou alterações na atividade do coagulante pela decomposição dos compostos orgânicos presentes, uma nova porção do extrato foi preparada e imediatamente utilizada em cada teste de proveta.

\subsubsection{ENSAIOS DE SEDIMENTAÇÃO BATELADA: TESTES DE PROVETA}

A massa correspondente à concentração de polvilho doce (Matuto-Amafil $囚$ ) determinada pelo planejamento experimental foi colocada em uma proveta de $250 \mathrm{~mL}$ e parte de seu volume preenchido com água destilada. A correspondente dosagem de coagulante foi inserida e o volume da proveta preenchido com água destilada até os $250 \mathrm{~mL}$. Em seguida, a proveta foi lentamente agitada realizando inversões durante 10 min e deixada em repouso para registro da variação da altura de líquido clarificado em relação ao tempo. 0 tempo de agitação de 10 min se deve à necessidade de homogeneizar o coagulante e promover a gradual formação dos flocos antes de iniciar a sua sedimentação.

Durante testes de proveta preliminares, observou-se a formação de 3 regiões de sedimentação e duas interfaces distintas. A fase superior (Região 1 - R1) era constituída de um líquido clarificado de baixa turbidez, que fazia interface com uma fase em que as partículas de polvilho de menor diâmetro estavam concentradas (Região 2 - R2), assim essa interface foi denominada interface IC. Na base da proveta houve a formação de uma região concentrada nas maiores partículas (Região 3 - R3), o que tornou mais visível a interface (Interface IV), localizada entre a fase turva e a região de compactação.

\subsubsection{TRATAMENTO ESTATÍSTICO}

A fim de estudar o efeito do coagulante sobre a sedimentação do polvilho, foi executado um planejamento experimental fatorial, no qual foram avaliados os efeitos de duas variáveis: concentração de polvilho em suspensão (Co) e dosagem de coagulante (Dc). Já que a $\mathrm{M}$. oleífera afeta pouco o pH do meio (NDABIGENGESERE; NARASIAH, 1998) e tem o seu efeito coagulante pouco afetado por ele dentro da faixa estudada (pH neutro a levemente ácido), o planejamento experimental não abordou essa variável.

Como no final do teste a interface movimenta-se lentamente, uma das respostas avaliadas foi o tempo em que as interfaces IC e IV levaram para atingir $95 \%$ do deslocamento total da interface. A altura final de sedimento também foi analisada, por revelar o grau de compactação da camada de espessado e, consequentemente, a porosidade da mesma.

As Equações 1 e 2 apresentam a codificação das variáveis concentração de polvilho Co (g.L-1) e dosagem de coagulante Do (mL em $250 \mathrm{~mL}$ de suspensão) em x1 e x2, respectivamente. Os testes foram feitos em provetas contendo suspensões com concentrações de polvilho de 100, 150 e 200 g.L-1. A faixa de concentrações escolhida levou em consideração a possibilidade de visualizar o deslocamento da interface de clarificado e o tempo para cada ensaio, já que maiores concentrações favorecem a visualização da interface, embora consumam maior tempo de sedimentação.

Cinco diferentes dosagens de coagulante foram utilizadas $(0,5,10,15$ e $20 \mathrm{~mL})$, totalizando 15 experimentos. Os dados experimentais foram tratados utilizando a metodologia do planejamento fatorial e a técnica de superfícies de resposta. Foi feita a regressão múltipla dos dados utilizando nível de significância de $10 \%$ para quantificar os efeitos das variáveis envolvidas, além de suas interações e contribuições quadráticas sobre as respostas.

$$
\begin{aligned}
& x_{1}=\frac{C o-150}{50}(1) \\
& x_{2}=\frac{D c-10}{5}(2)
\end{aligned}
$$




\subsection{TESTES DE SEDIMENTAÇÃO CONTÍNUA}

Determinada a dosagem de coagulante que resultou em um menor tempo para a sedimentação do polvilho doce, foram feitos testes de sedimentação contínua em unidade experimental, tendo como finalidade observar o processo e determinar as suas condições de operação e viabilidade.

\subsubsection{UNIDADE EXPERIMENTAL}

Os experimentos foram realizados em sedimentador contínuo adaptado para a operação com a suspensão de fécula. A Figura 4 apresenta um esquema da unidade de sedimentação, composta por:

- Bomba peristáltica

- Agitador magnético com béquer contendo suspensão de polvilho doce

- Tubos de silicone

- $\quad$ Recipiente de coleta de clarificado

- Recipiente de coleta de lama

- Sedimentador construído em plástico com suporte de madeira de $60 \mathrm{~cm}$. A alimentação é feita na parte superior e no centro do equipamento, $5 \mathrm{~cm}$ abaixo do topo, sendo o clarificado descarregado por um tubo-vertedouro localizado na lateral do tanque, acima do ponto de alimentação e a lama descarregada no fundo do equipamento, por meio de uma abertura.

As principais dimensões do tanque de sedimentação estão representadas na Figura 5.

Figura 4 - Unidade experimental

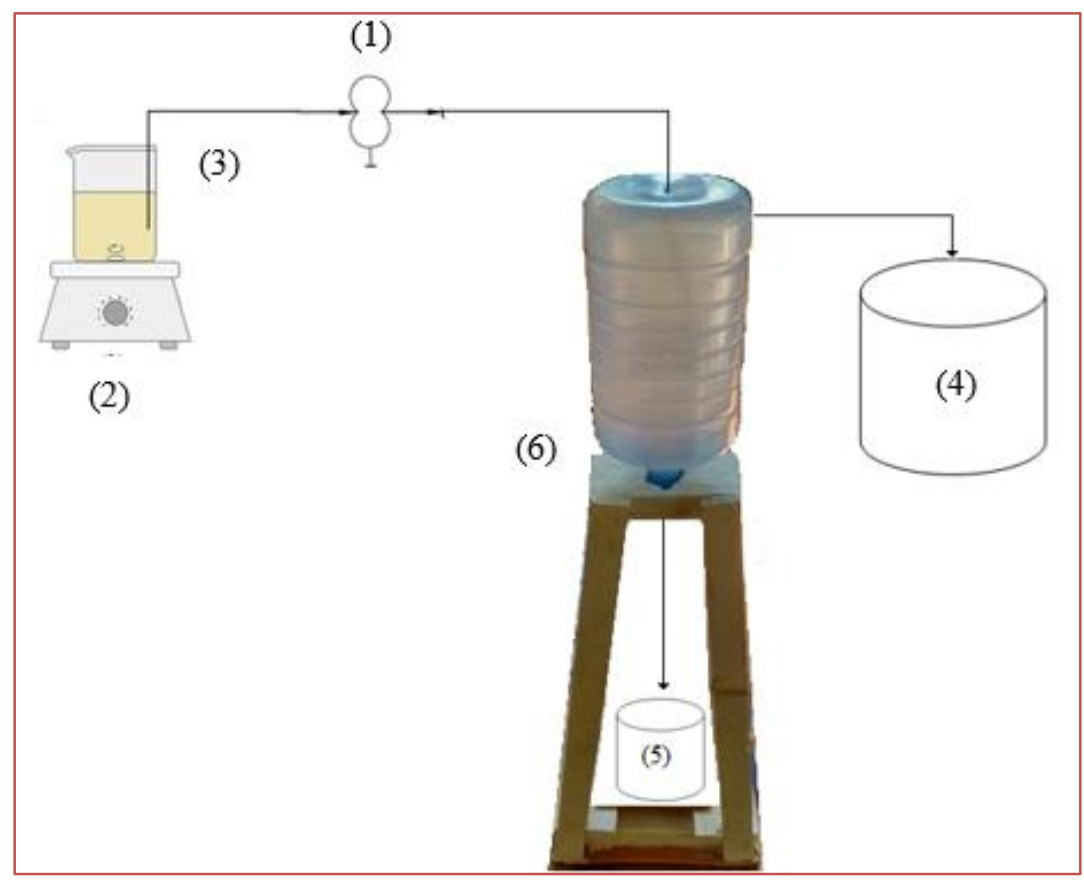


Figura 5 - Vista lateral com as principais dimensões do sedimentador $(\mathrm{cm})$

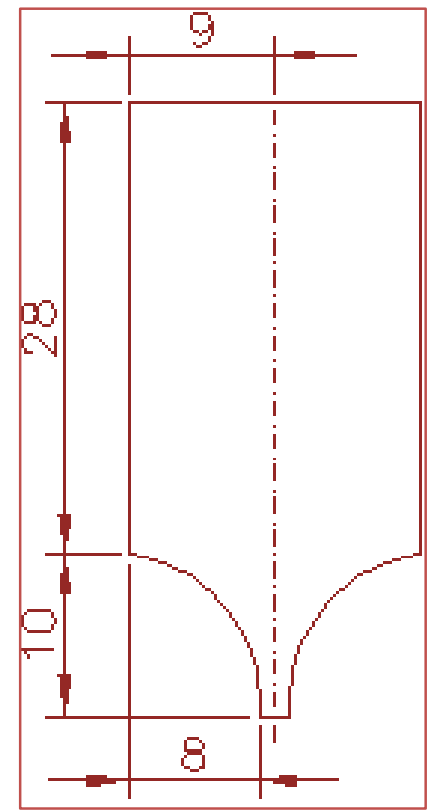

Durante os testes preliminares, observou-se que o lodo concentrado no fundo do equipamento apresentou elevada resistência ao escoamento quando submetido a raspagem, assumindo comportamento comum a fluidos dilatantes. Devido a essa característica, não foram utilizados raspadores no sedimentador, sendo a descarga da lama feita somente por meio da gravidade.

\subsubsection{DETERMINAÇÃO DA CAPACIDADE DO SEDIMENTADOR CONTÍNUO}

Nesta etapa, foi calculada a capacidade ou vazão volumétrica $\mathrm{F}$ de suspensão a ser alimentada no sedimentador contínuo, nas condições de Co=100 g.L-1, com dosagem de coagulante Dc=10 mL, que foi a dosagem que resultou em um menor tempo de sedimentação nos testes de proveta para essa concentração de alimentação. Optou-se por utilizar suspensão de polvilho doce na concentração de 100 g.L-1 por ser o valor mais próximo ao atingido após extração da fécula, cuja suspensão é encaminhada para as centrífugas nas fecularias (Figura 3).

Para o projeto, optou-se pela utilização do método de Kynch por ele necessitar de apenas um teste de proveta e pelo fato de que a curva de sedimentação floculenta do polvilho ter apresentado característica de sedimento pouco compressível, havendo assim um menor comprometimento dos resultados obtidos pelo método.

A partir da obtenção dos valores de v e zi para cada ponto da curva de dados experimentais, foi calculado a mínima capacidade obtida pela Equação 3. 0 valor zi representa a altura na qual a suspensão ocuparia se todas as regiões tivessem a concentração C (Equação 4), sendo dado pelo valor de $z$ no qual a reta que tangencia a curva dos pontos experimentais intercepta o eixo y; v corresponde à velocidade de sedimentação, que é o valor da inclinação dessa reta.

$$
\begin{gathered}
\frac{F}{A}=\frac{1}{C_{a}} \frac{1}{\left(\frac{1}{C}-\frac{1}{C_{L}}\right)}(3) \\
C=\frac{C_{a} Z_{0}}{z i}(4)
\end{gathered}
$$

em que $Z_{0}$ é a altura inicial da interface de sedimentação no teste de proveta.

A máxima concentração alcançada no teste de proveta para a suspensão de concentração inicial de 100 g.L-1 e dosagem de coagulante igual a $10 \mathrm{~mL}$ foi igual a 625 g.L-1, sendo esta, portanto, a concentração crítica obtida para o sedimento de polvilho. Assim, a concentração de lama utilizada nos cálculos da 
capacidade da unidade experimental deve ser menor que a concentração crítica. Portanto optou-se pelo valor de 600 g.L-1, que no caso de fecularias, é uma concentração de suspensão similar à que deixa a etapa de centrifugação.

A viabilidade da altura do sedimentador da unidade experimental para a operação foi verificada, calculando-se a altura da região de concentração variável (HC) e do fundo ou parte cônica do equipamento (H2), em que HC é calculado pela Equação 5 (DAMASCENO; MASSARANI, 1990; DAMASCENO; MASSARANI, 1993) e H2 é dado pela Equação 6.

$$
\begin{gathered}
H_{C}=\frac{4}{3} \frac{F C_{a} \tau_{r}}{A \rho_{s}}\left(\frac{\rho_{s}-\rho}{\rho_{L}-\rho}\right)(5) \\
H_{2}=0,072 * D(6)
\end{gathered}
$$

no qual $\rho_{s}$ é a densidade do sólido, $\rho$ é a densidade da água e $\tau_{r}$ é o tempo de compactação. A densidade do polvilho doce foi determinada por picnometria, utilizando água destilada.

\subsubsection{PROCEDIMENTO DE OPERAÇÃO CONTÍNUA DA UNIDADE EXPERIMENTAL}

0 agitador magnético era ligado de modo a homogeneizar a suspensão de polvilho doce contendo a determinada dosagem de coagulante por no mínimo 10 min antes de ligar a bomba de alimentação do sedimentador. 0 volume do recipiente de alimentação era completado com suspensão previamente agitada de polvilho doce e coagulante, conforme necessário.

O início da operação da unidade foi feito com o sedimentador preenchido com a suspensão de polvilho na concentração de 100 g.L-1, contendo coagulante. O fundo do sedimentador permaneceu fechado, impedindo a descarga de lama. Após 15 min, a bomba peristáltica foi ligada e deu-se início à descarga de clarificado. Completadas $2 \mathrm{~h}$ e $30 \mathrm{~min}$ de operação, a camada de sedimento encontrava-se formada e o fundo do recipiente foi aberto para dar início às coletas.

No ponto de descarga de lama, foram utilizadas aberturas com dois tamanhos diferentes, sendo utilizados os diâmetros de abertura de $0,75 \mathrm{~cm}$ e de $0,30 \mathrm{~cm}$ para os testes 1 e 2 , respectivamente.

Amostras de lodo e clarificado foram coletadas simultaneamente a cada $30 \mathrm{~min}$, pesadas e encaminhadas para a estufa por $24 \mathrm{~h}$, de modo retirar a água presente e determinar a concentração de sólidos presentes em suspensão por meio de gravimetria, bem como as vazões de clarificado e lodo.

\section{RESULTADOS E DISCUSSÕES}

Inicialmente, foram avaliadas as respostas do planejamento experimental e realizado o tratamento estatístico para selecionar a dosagem adequada de coagulante. Com os valores de concentração de sólidos e dosagem de coagulante, foram definidos os valores de projeto para operação da unidade experimental. Também foi realizada análise da viscosidade da suspensão de polvilho na concentração definida para o lodo.

\subsection{TESTES DE PROVETA}

A Figura 6 apresenta os testes de proveta em diferentes tempos, comparando o teste sem coagulante e o teste com $10 \mathrm{~mL}$ do extrato de M. oleifera, em que pode-se visualizar a presença das três fases mencionadas, o que originou duas interfaces (IC e IV), que se moviam com o tempo, até que estas se encontravam devido ao desaparecimento da região intermediária. Observa-se que o teste com coagulante apresentou um maior deslocamento da interface de clarificado num menor tempo, o que corresponde a uma maior velocidade de sedimentação de partículas de polvilho. 
A Tabela 2 apresenta a altura final da camada de polvilho espessado e os tempos que cada teste levou para atingir 95\% do deslocamento total da interface de sedimentação. Nos testes em que houve adição de coagulante foi observado um menor tempo de sedimentação do polvilho, principalmente para a interface IC. Comparando testes com a mesma concentração de sólidos, foi possível observar que a altura final da camada de espessado foi maior quando utilizado o coagulante, indicando menor grau de compactação das partículas.

Comparando-se os tempos entre as interfaces, observa-se que rapidamente a altura da Região 3 se tornou constante, ou seja, a maioria das partículas sedimentam rapidamente sendo que apenas as partículas leves permanecem na Região 2. Assim, optou-se por realizar o teste estatístico para o tempo de sedimentação correspondente à interface IC, já que esta representa a completa sedimentação da suspensão.

A Figura 7-(a) mostra a altura da interface IC em função do tempo, para as concentrações iniciais de 100, 150 e 200 g.L-1 sem a adição de coagulante. Em (b), (c) e (d) é representada a altura da interface IC em função do tempo para as concentrações iniciais de polvilho de 100, 150 e 200 g.L-1, respectivamente, para várias dosagens de coagulante.

Figura 6 - Testes de proveta com concentração de polvilho de 100 g/L nos tempos de 1, 2, 3 e 14 h: (a) Sem coagulante (b) com $10 \mathrm{ml}$ de coagulante.

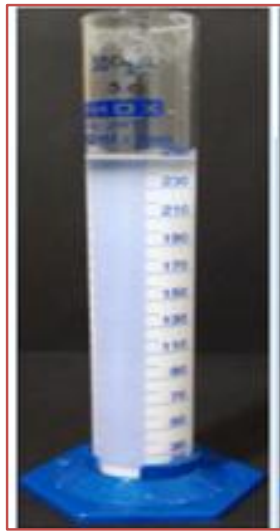

$1 \mathrm{~h}$

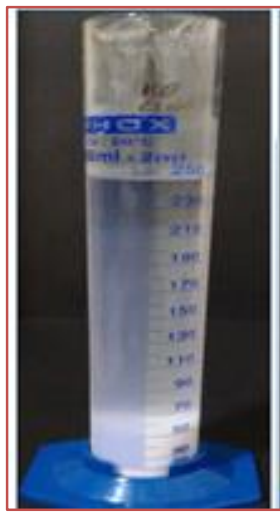

$1 \mathrm{~h}$

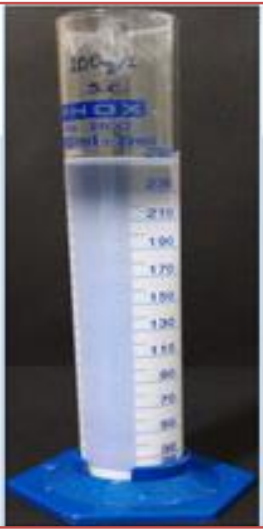

(a)

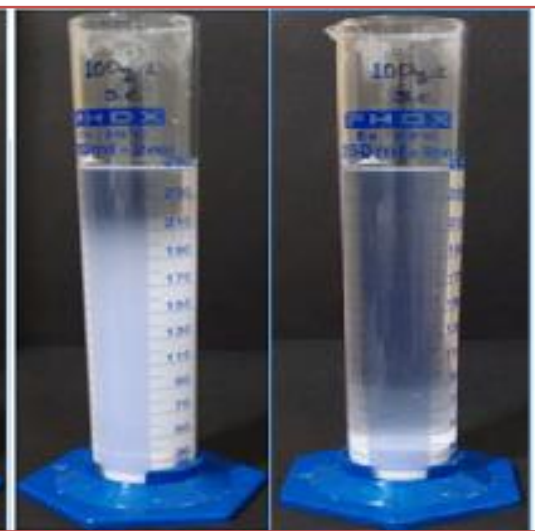

$2 \mathrm{~h}$

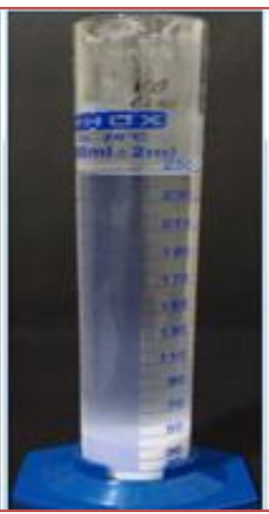

3h

$14 \mathrm{~h}$

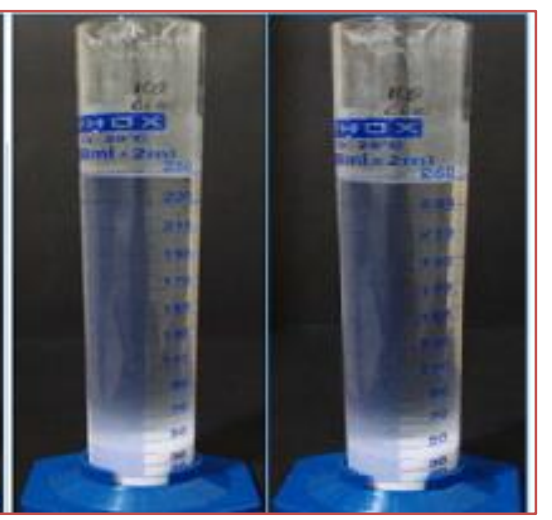

(b)
$3 \mathrm{~h}$

$14 \mathrm{~h}$ 
Tabela 2 - Planejamento experimental: respostas dos testes de proveta

\begin{tabular}{|c|c|c|c|c|c|}
\hline Teste & $\begin{array}{c}x_{1} \\
\text { (Co [g.L-1]) }\end{array}$ & $\begin{array}{c}x_{2} \\
\text { (Do }[\mathrm{mL}])\end{array}$ & $\begin{array}{l}\text { Altura final } \\
\mathrm{H}(\mathrm{cm})\end{array}$ & $\begin{array}{c}\text { Tempo 95\% IC } \\
t_{I C}(\min )\end{array}$ & $\begin{array}{c}\text { Tempo 95\% IV } \\
t_{I V}(\min )\end{array}$ \\
\hline 1 & $-1(100)$ & $-2(0)$ & 3,15 & 795 & 120 \\
\hline 2 & $0(150)$ & $-2(0)$ & 4,68 & 834 & 120 \\
\hline 3 & $1(200)$ & $-2(0)$ & 6,39 & 870 & 225 \\
\hline 4 & $-1(100)$ & $-1(5)$ & 3,60 & 88 & 80 \\
\hline 5 & $0(150)$ & $-1(5)$ & 5,04 & 217 & 170 \\
\hline 6 & $1(200)$ & $-1(5)$ & 6,66 & 240 & 260 \\
\hline 7 & $-1(100)$ & $0(10)$ & 3,60 & 90 & 90 \\
\hline 8 & $0(150)$ & $0(10)$ & 5,04 & 167 & 167 \\
\hline 9 & $1(200)$ & $0(10)$ & 6,66 & 260 & 260 \\
\hline 10 & $-1(100)$ & $1(15)$ & 3,42 & 87 & 80 \\
\hline 11 & $0(150)$ & $1(15)$ & 5,22 & 160 & 160 \\
\hline 12 & $1(200)$ & $1(15)$ & 6,75 & 260 & 260 \\
\hline 13 & $-1(100)$ & $2(20)$ & 3,42 & 88 & 80 \\
\hline 14 & $0(150)$ & $2(20)$ & 5,13 & 180 & 180 \\
\hline 15 & $1(200)$ & $2(20)$ & 6,84 & 270 & 270 \\
\hline
\end{tabular}

Figura 7 - Altura da interface IC em função do tempo, para: (a) Dc=0, nas concentrações iniciais de polvilho de 100, 150 e 200 g.L-1; (b) Co=100 g.L-1 (c) Co=150 g.L-1 (d) Co=200 g.L-1 e várias dosagens de coagulante

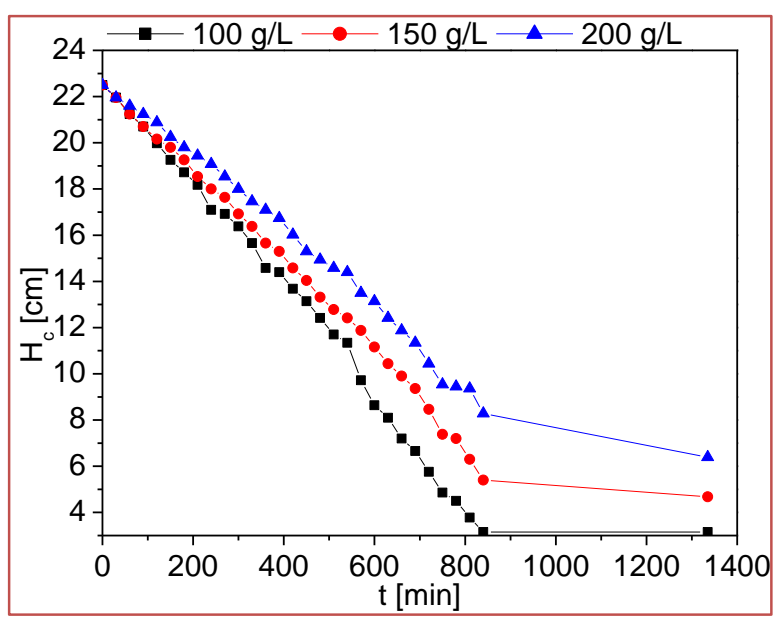

(a)

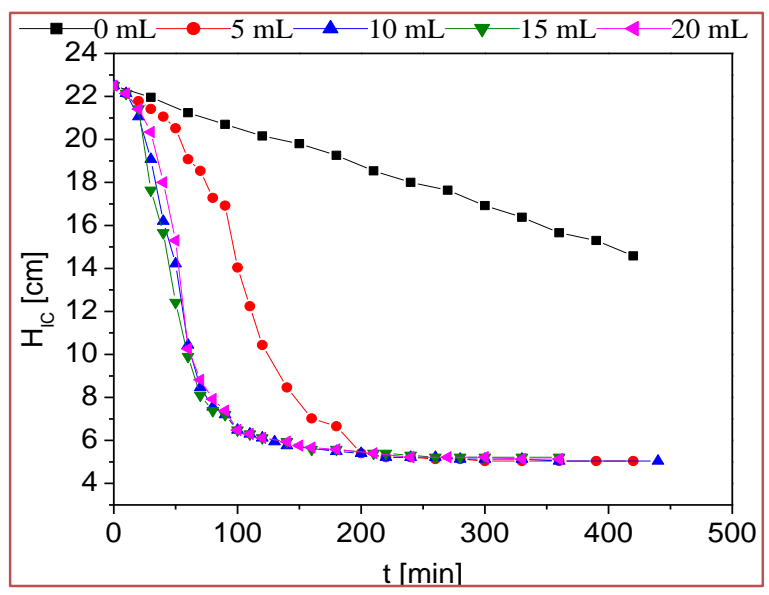

(c)

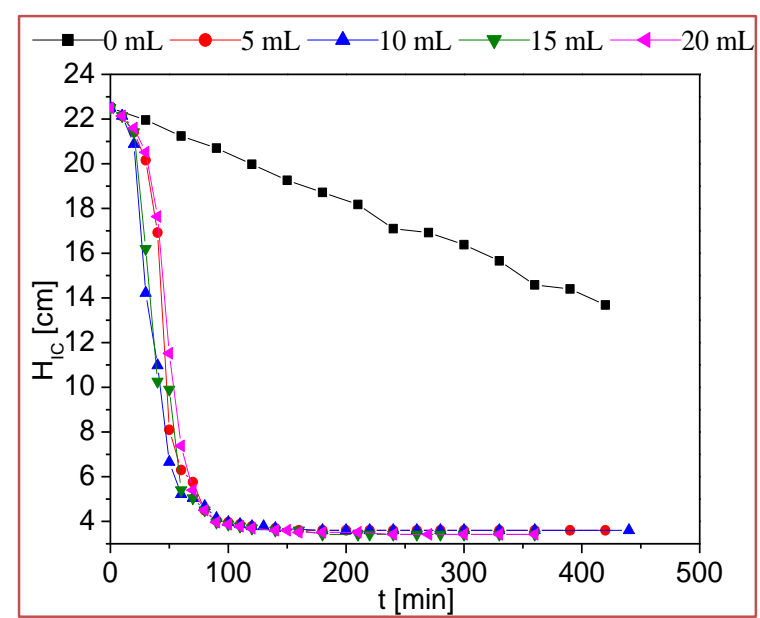

(b)

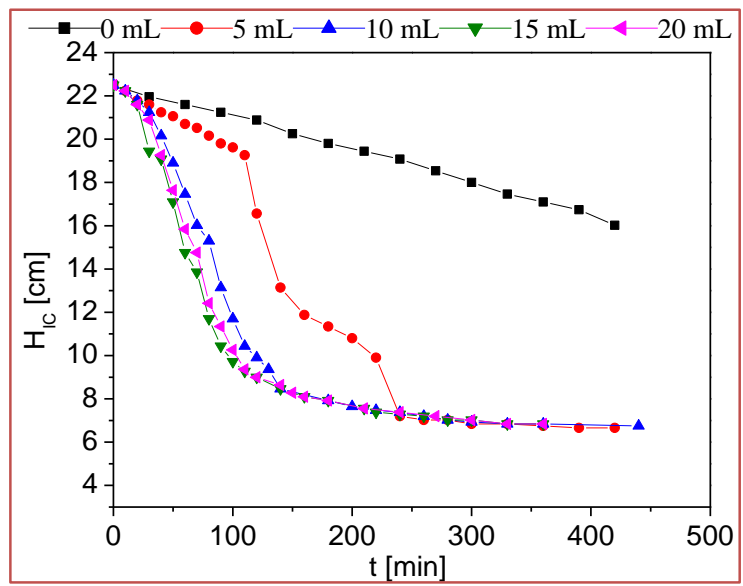

(d) 
Pode-se observar claramente que a adição de coagulante diminuiu o tempo de sedimentação, mas para dosagens acima de $10 \mathrm{~mL}$ para $250 \mathrm{~mL}$ de suspens, aparentemente não há diferenças entre o comportamento transiente da altura da interface IC. Observa-se ainda que a mudança na concentração inicial de particulado altera significativamente a altura final da interface, como esperado.

\subsubsection{ALTURA FINAL DA CAMADA DE SEDIMENTO (H)}

O acompanhamento da altura final da camada de lodo ou leito consolidado $(\mathrm{H})$ foi feito a fim de avaliar o efeito do coagulante sobre a compactação máxima de polvilho. Um maior espessamento é de interesse na etapa de sedimentação para que se possa obter um produto com menor quantidade de água, facilitando a etapa subsequente de secagem solar. A Equação 7 apresenta os termos que influenciaram significativamente a altura final da camada de lodo, além dos coeficientes de regressão de cada variável $\left(\mathrm{R}^{2}=0,995\right)$.

$$
H=5,139+1,611 x_{1}+0,081 x_{2}-0,049 x_{2}^{2}(7)
$$

É possível observar que além do efeito significativo das variáveis isoladas, também há presença do termo quadrático relativo à dosagem de coagulante. Por meio da análise da superfície de resposta (Figura 8), observa-se que o aumento na concentração inicial de polvilho na suspensão conduz à uma camada mais espessa de sedimento, uma vez que há uma maior quantidade de partículas. Quanto à dosagem de coagulante, dosagens intermediárias (10 e $15 \mathrm{~mL}$ ) levaram a alturas de espessado levemente maiores que as demais condições, o que indica a formação de flocos maiores.

Embora os processos de coagulação acelerem a taxa de sedimentação, um segundo efeito ocorre no sistema. Devido às forças atrativas entre as partículas causadas pela ação coagulante, os flocos que atingem o leito consolidado se afixam nele na posição de primeiro contato, não ficando livres para empacotar (LANDMAN; WHITE; BUSCALL, 1988). Assim, devido a esse aumento na porosidade da camada no leito, os testes que utilizaram coagulante tiveram uma altura final de espessado cerca de $12 \%$ maior que a altura dos testes sem a adição do coagulante.

Figura 8 - Superfície de resposta para altura final de compactação em função da concentração de polvilho e da dosagem de coagulante

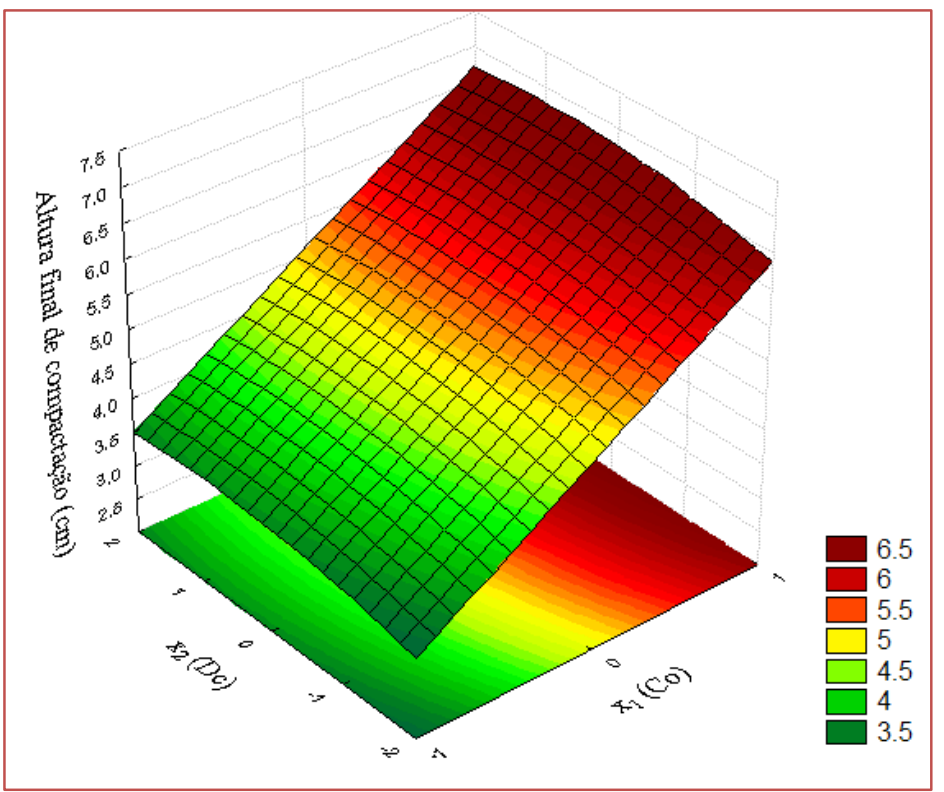




\subsubsection{TEMPO DE SEDIMENTAÇÃO DAS INTERFACES IC (TIC)}

A Equação 8 apresenta os termos que influenciaram significativamente o tempo de sedimentação da interface IC (tIC) $\left(\mathrm{R}^{2}=0,871\right)$.

$$
t_{I C}=117,160+75,20 x_{1}-132,00 x_{2}+94,95 x_{2}^{2}(8)
$$

Pode-se observar que tanto a concentração inicial de partículas quanto a dosagem do coagulante influenciaram o tempo de sedimentação da Região 2. No entanto, a dosagem de coagulante influencia de forma mais significativa. Os maiores tempos para a sedimentação ocorreram para as condições sem o coagulante. Um aumento na dosagem de coagulante aumenta a velocidade da interface, reduzindo o tempo de sedimentação. Mas, devido ao termo quadrático, a partir das condições de dosagem de $10 \mathrm{~mL}$, há um pequeno aumento no tempo de sedimentação, como pode ser observado na Figura 9.

Figura 9 - Superfície de resposta para o tempo de sedimentação da interface IC em função da concentração de polvilho e da dosagem de coagulante

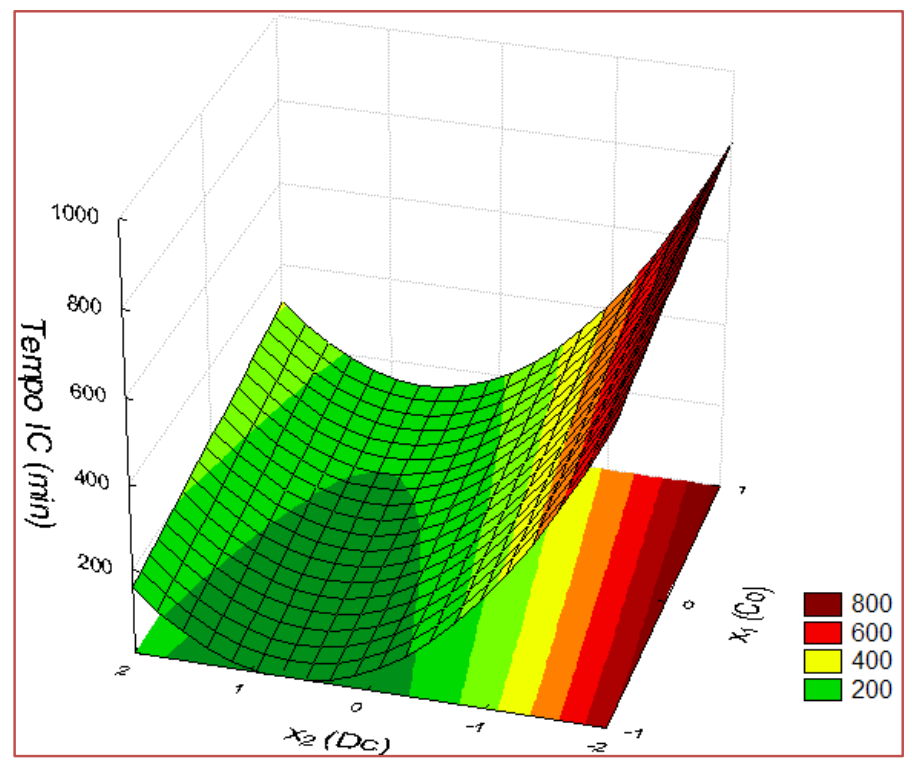

Assim, dosagens elevadas do coagulante desfavorecem o tempo de sedimentação em relação às demais dosagens. Isso pode ser justificado pelo fato de uma superdosagem de coagulante poder levar à formação de flocos com estruturas irregulares, de menor esfericidade e, portanto, menor velocidade terminal. Tal comportamento foi observado em estudos com outras suspensões e coagulantes, realizados por Arouca (2007) e também por Fernandes et al. (2010). Assim, é necessário que seja feita uma dosagem adequada de coagulante para evitar o seu desperdício e resultados de menor eficiência. Neste trabalho, sugere-se dosagens a partir de $10 \mathrm{~mL}$ para $250 \mathrm{~mL}$ de suspensão, pois reduziram em média $80 \%$ o tempo de sedimentação total.

\subsection{TESTES DE SEDIMENTAÇÃO CONTÍNUA}

\subsubsection{CAPACIDADE DA UNIDADE EXPERIMENTAL}

A Figura 10 apresenta o ajuste não linear dos dados do teste de proveta nas condições escolhidas para operação do sedimentador contínuo ( $\mathrm{Ca}=100$ g.L-1; Dc=10 mL/L), dado pela Equação 9 (R2=0,993). Com a derivada da Equação 15, foram determinados os valores da velocidade de sedimentação v e de zi em cada altura dada pelos pontos experimentais. A capacidade do sedimentador calculada pelo método de Kynch foi de $42 \mathrm{~cm}^{3} \cdot \min -1$ ou 2,5 L.h-1. 


$$
H_{I C}=3,61+47,87 e^{(-t / 1188,27)}(9)
$$

Também foram calculadas as alturas das regiões de concentração variável (HC) e da parte cônica do sedimentador (H2), com a finalidade de verificar se essa dimensão da unidade experimental estaria apropriada para operar nas condições escolhidas. Com a derivada da Equação 15 foi possível determinar o ponto correspondente a CL, que é o tempo no qual a reta que intercepta o gráfico em zmín tangencia a curva ajustada, que equivale a $\mathrm{tL}=2,66 \mathrm{~h}$. Subtraindo esse tempo ao que corresponde ao final da tendência linear, obtém-se um valor de $\tau$ r de $2 \mathrm{~h}$, o resultando em um valor de $\mathrm{HC}$ de 5,6 cm, considerando a densidade do polvilho doce, obtida na picnometria, de 1,49 g.cm-3. Assim, a altura da unidade experimental é adequada para realizar a operação de sedimentação. Para a altura da região de líquido clarificado e concentração constante (H1), foi assumido o valor de $27 \mathrm{~cm}$ ao invés do valor de projeto $(0,6$ $\mathrm{cm}$ ) devido à escala do equipamento utilizado.

Figura 10 - Ajuste dos pontos experimentais do teste de proveta $\mathrm{Ca}=100 \mathrm{~g} / \mathrm{L} \mathrm{e} \mathrm{DC}=10 \mathrm{~mL}$

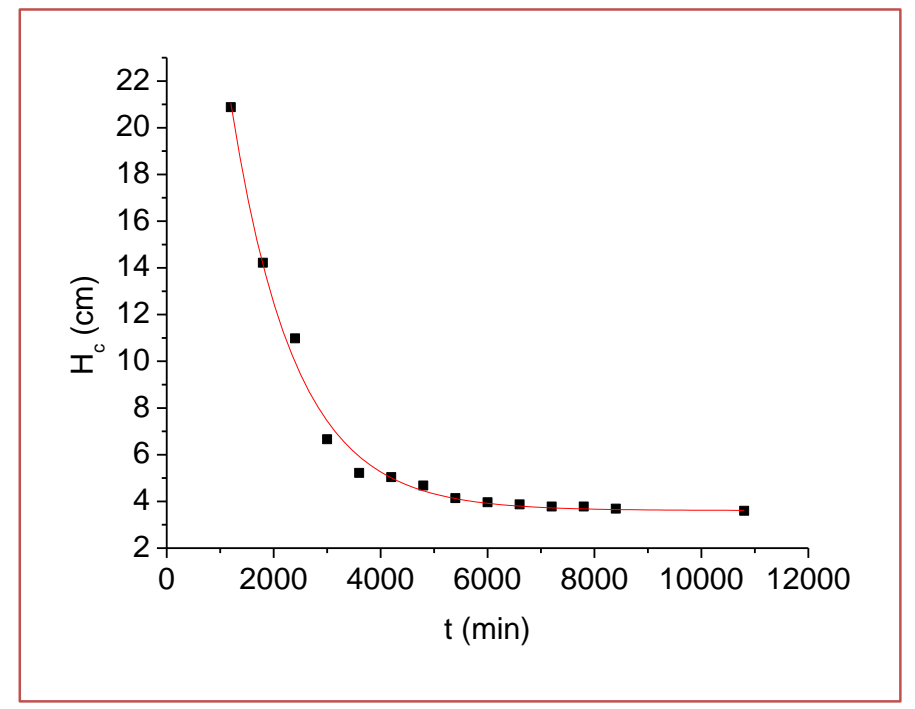

\subsubsection{OPERAÇÃO DO SEDIMENTADOR CONTÍNUO}

Na Tabela 3 estão dispostos os valores de concentração de sólidos presentes na lama e no clarificado em relação ao tempo de coleta e ao teste executado com diferentes diâmetros de abertura do orifício de saída de lama. As vazões de clarificado e lama somadas permaneceram de acordo com a capacidade alimentada no sedimentador $\left(42 \mathrm{~cm}^{3} \cdot \mathrm{min}-1\right)$.

Tabela 3 - Relação de concentração de sólidos na lama e clarificado nas amostras coletadas durante os testes de sedimentação contínua (F=42 $\mathrm{cm}^{3}$.min-1; Ca=100 g.L-1 e CL=600 g.L-1)

\begin{tabular}{|c|c|c|c|c|c|}
\hline Teste & $\begin{array}{l}\text { Tempo de coleta } \\
\text { (min) }\end{array}$ & $\begin{array}{c}\text { Concentração de } \\
\text { sólidos no clarificado } \\
\text { (g.L-1) }\end{array}$ & $\begin{array}{c}\text { Concentração de } \\
\text { sólidos na lama (g/L- } \\
\text { 1) }\end{array}$ & $\begin{array}{c}\mathrm{Fc} \\
\left(\mathrm{cm}^{3} \cdot \mathrm{min}-1\right)\end{array}$ & $\begin{array}{c}\mathrm{FL} \\
\left(\mathrm{cm}^{3} \cdot \mathrm{min}-1\right)\end{array}$ \\
\hline $1^{*}$ & 30 & 0,45 & 415,40 & 39 & 3 \\
\hline \multirow{4}{*}{2} & 5 & 0,28 & 578,85 & 40 & 1,5 \\
\hline & 35 & 0,30 & 583,00 & 40 & 1,5 \\
\hline & 65 & 0,47 & 550,71 & 35 & 1,7 \\
\hline & 95 & 0,4 & 579,2 & 39 & 1,4 \\
\hline
\end{tabular}

${ }^{*}$ Teste foi interrompido devido a problemas operacionais. 
A lama foi descarregada por gravidade, não ocorrendo problemas como entupimento ou interrupção de seu escoamento. Contudo, durante o teste 1 ocorreu descarga de líquido das regiões acima do leito consolidado pelo orifício de saída de lama após $40 \mathrm{~min}$ de teste. Atribui-se esse fato pela formação de um canal preferencial dentro do equipamento. Devido ao comportamento reológico da suspensão de polvilho doce, que aumenta sua resistência ao escoamento quando concentrada e submetida a tensões elevadas, sua descarga foi feita somente no centro do equipamento, não ocorrendo o deslizamento da suspensão presente mais próximo das paredes para o bocal de descarga.

Assim, a pressão exercida pela coluna de fluido acima da suspensão concentrada de polvilho doce presente no leito consolidado provocava um aumento da viscosidade da lama e prejudicava seu escoamento uniforme para o local de descarga. Portanto, após finalizada a descarga de parte da lama, o líquido presente nas camadas superiores percolava o canal preferencial formado no leito consolidado e era imediatamente descarregado.

De modo a evitar a formação de canal preferencial no centro do equipamento, foi utilizado um menor diâmetro de abertura do orifício de descarga no teste 2. Para este teste, os valores obtidos para a concentração de lama foram pouco menores que o estabelecido no projeto (600 g.L-1), ademais, as concentrações de sólidos no clarificado foram baixas. Assim, o equipamento promoveu a separação sólidolíquido, espessando o polvilho no fundo e removendo a água pelo topo.

Os dados de vazão e concentração da lama do underflow mostraram que o sedimentador estava na eminência de atingir o estado estacionário, pois variaram em torno de um valor próximo ao de projeto. No entanto, como o tempo de coleta foi curto, não foi possível verificar se o diâmetro do bocal de descarga do teste 2 resolveu de fato os problemas operacionais de descarga do espessado, uma vez que se observou uma pequena variação na altura do leito consolidado, no interior do sedimentador.

Assim, foi possível realizar a concentração de suspensões de polvilho doce por meio do processo de sedimentação contínua quando empregado coagulante de extraído da semente de M. oleífera; porém, devido ao comportamento reológico apresentado por suspensões concentradas de fécula, a descarga da lama deve ser ponderada. Uma alternativa é utilizar tanques de sedimentação sem partes cônicas ou estreitamentos para o bocal de saída de lodo e instalar bombas do tipo parafuso ou rosca sem fim para promover a retirada da lama do fundo do equipamento.

\section{CONCLUSÃO}

Houve em média uma redução de 80 \% no tempo de sedimentação do polvilho doce por meio da aplicação do extrato de M. oleífera. Para promover a maior eficiência, foi estabelecido o uso de dosagens de coagulante iguais a $10 \mathrm{~mL}$ para cada $250 \mathrm{~mL}$ de suspensão de polvilho doce nas faixas de concentração de 100 a 200 g.L-1. A análise estatística do planejamento experimental apontou que superdosagens de coagulante causaram aumento no tempo de sedimentação, o que ocorre devido à formação de partículas irregulares com menor esfericidade.

O uso de coagulantes promoveu em média um aumento de $12 \%$ na altura final de leito consolidado devido à presença de partículas de maior tamanho, já que empacotam menos.

Com a adição do extrato de M. oleifera, torna-se interessante a realização da operação de concentração do polvilho por meio da sedimentação contínua. A unidade experimental cuja capacidade foi estimada pelo método de Kynch obteve lodo em concentrações próximas às de projeto e clarificado com baixa concentração de sólidos (0,4 g.L-1).

0 comportamento reológico da suspensão espessada possui características comuns às observadas em um fluido dilatante: quando submetida a um aumento de tensão de cisalhamento, sua viscosidade aumenta, o que reflete em uma resistência ao seu escoamento. Por isso, com a descarga feita apenas por gravidade, houve formação de canais preferenciais e o líquido presente nas camadas acima do leito consolidado foi descarregado.

Assim, é recomendável que seja evitando utilizar partes cônicas ou estreitamentos na saída de lama do sedimentador contínuo, pois prejudicam a sua descarga e favorecem a formação de canal preferencial. Também é interessante que seja estudada a remoção de lodo utilizando bombas do tipo rosca sem fim devido às observadas propriedades da suspensão de fécula de mandioca a altas concentrações. 


\section{AGRADECIMENTOS}

À UFTM, em especial ao PPGMQMG e PMPIT. À Rede Mineira de Química, à Fapemig, Capes e CNPq.

\section{NOMENCLATURA}

A Área da secção transversal do sedimentador, M0L2T0

C Concentração de sólidos em suspensão, M1L3T0

Co Concentração inicial de sólidos em suspensão, M1L3T0

D Diâmetro do sedimentador, M0L1T0

Dc Dosagem de coagulante, M0L3T0

F Capacidade ou vazão volumétrica de suspensão, M0L3T-1

$\mathrm{H} \quad$ Altura final da camada de sedimento, M0L1T0

Ca Concentração inicial de sólidos em suspensão, M1L3T0

CL Concentração de sólidos no lodo ou lama, M1L3T0

H1 Altura da região de clarificada e de concentração constante, M0L1T0

H2 Altura do fundo do sedimentador, MOL1T0

Hc Altura da região de compactação, M0L1T0

$t_{I C} \quad$ Tempo de sedimentação da interface IC, M0L0T1

vSO Velocidade inicial de sedimentação, M0L1T-1

x1, x2 Variáveis codificadas: concentração da suspensão e dosagem de coagulante

zi Altura da suspensão na concentração C, M0L1T0

$z_{\mathrm{m} i n} \quad$ Parâmetro de altura da interface de clarificado em teste de proveta referente ao método de Biscaia Jr., M0L1T0

$z_{0} \quad$ Altura inicial da interface de clarificado, , MOL1T0

$\phi \quad$ Fração mássica

$\phi_{c} \quad$ Fração mássica crítica

$\mu \quad$ Viscosidade, M1L-1T-1

$\theta_{\text {min }} \quad$ Parâmetro do tempo de sedimentação em teste de proveta referente ao método de Biscaia Jr., MOLOT1

$\rho_{s} \quad$ Densidade do polvilho doce, M1L-3T0

$\rho \quad$ Densidade da água, M1L-3T0

$\rho_{L} \quad$ Densidade do lodo ou lama, M1L-3T0

$\tau_{r} \quad$ Tempo de residência do lodo na região de compactação, M0L0T1 


\section{REFERÊNCIAS}

[1] ANWAR, F. et al. Moringa oleifera: a food plant with multiple medicinal uses. Phytotherapy Research. v. 21, n.1, p. 17-25, 2007.

[2] AROUCA, F. O. Uma contribuição ao estudo da sedimentação gravitacional em batelada. Tese de Doutorado, FEQUI/UFU, Uberlândia, 2007.

[3] BÉLTRAN-HEREDIA, J.; SÁNCHEZ-MARTÍN, J. Removal of sodium lautyl sulfate by coagulation/flocculation with Moringa oleifera seed extract. Journal of Hazardous Materials. v. 164, p. 713-719, 2009.

[4] BISCAIA JR., E. C. Simplificação matemática do método de Kynch. Comunicação pessoal, 1982.

[5] BRASIL. Resolução CNNPA nº 12 de 1978. Amidos e féculas.

[6] CEPEA. Mandioca. Disponível em: < http://cepea.esalq.usp.br/mandioca/> Acesso em: 8 de jul. 2016.

[7] CEREDA, M. P. Indústria de fécula. In: FARIAS, A. R. N. et al. Processamento e utilização da mandioca. 1a ed. Cruz das Almas: Embrapa Mandioca e Fruticultura Tropical, 2005.

[8] CEREDA, M. P. O processamento da mandioca. Direção: Patrícia Resende. Centro de produções técnicas. Vídeo online. 2014. Disponível em: <https://www.youtube.com/watch?v=P11g6FT40-8.> Acesso em 8 fev 2016.

[9] COLDEBELLA, P. F. et al. Avaliação de diferentes métodos de preparação do coagulante natural Moringa oleifera Lam para utilização no tratamento de água superficial. Anais do XXXVI Congresso Brasileiro de Sistemas Particulados - ENEMP. v. 2, p.1192-1201. Maceió: Edufal, 2013.

[10] CREMASCO, Marco Aurélio. Operações unitárias em sistemas particulados e fluidomecânicos. São Paulo: Bluthcer, 2012. 423p.

[11] DAIUTO, R. R.; CEREDA, M. P.; CARVALHO, J. J. C. B. Biossíntese de amido. In: CEREDA, M. P.; VILPOUX, 0. (Coord.). Propriedades gerais de amido. São Paulo: Fundação Cargill, 2002, v.1, cap. 3, p. 57-73.

[12] DAMASCENO, J. J. R.; MASSARANI, G. Uma análise do método de Kynch para o projeto de sedimentadores. Anais do XVII Encontro sobre Escoamento em Meios Porosos, p. 283-290, 1990.

[13] DAMASCENO, J. J. R.; MASSARANI, G. Projeto e análise do desempenho de sedimentadores contínuos. Ciência \& Engenharia/UFU. Ano 2, nº 2, p. 61-76, 1993.

[14] FERNANDES, N. M. G. et al. Influência do pH de coagulação e da dose de sulfato de alumínio na remoção de oocistos de Crystosporidium por filtração direta descendente. Engenharia Sanitária e Ambiental. v.15, n. 4, p. 375-384, 2010 .

[15] JAHN, S. A. A. Moringa oleifera for food and water purification - selection of clones and growing of anual short stem. Entwicklung + Landlicher Raum. v. 23, n. 4, p. 22-25, 1989.

[16] KYNCH, G. J. A theory of sedimentation. Trans. Faraday Soc., v. 48, p. 166, 1952.

[17] LANDMAN, K. A.; WHITE, L. R.; BUSCALL, R. The continuous-flow gravity thickener: steady state behavior. AIChE Journal. v. 34, n.2, p. 239-252, 1988.

[18] LEONEL, M.; JACKEY, S.; CEREDA, M. P. Processamento industrial de fécula de mandioca e batata doce: um estudo de caso. Food Science and Technology. v. 18, n. 3, p. 343-345, 1988.

[19] LIMA, U. A. Manual técnico de beneficiamento e industrialização da mandioca. São Paulo: Secretaria de Ciência e Tecnologia, 1982. v.2. 56 p.

[20] MASSARANI, G. Fluidodinâmica em sistemas particulados. 2ª ed. Ed. UFRJ. 2001.

[21] MATSUURA, F. C. A. U.; FOLEGATTI, M. I. S.; SARMENTO, S. Iniciando um pequeno grande negócio agroindustrial: processamento de mandioca. Brasília: Embrapa/Sebrae, 2003.

[22] MENDES, C. G. N. Estudo da coagulação e floculação de águas sintéticas e naturais com turbidez e cor variáveis. Tese de doutorado. Escola de engenharia de São Carlos, Universidade do Estado de São Paulo. São Carlos, 1989.

[23] MUYIBI, S. A.; EVISON, L. M. Moringa oleifera seeds for softening hardwater. Water research. v. 29, n. 4, p. 1099-1105, 1994.

[24] NDABIGENGESERE, A.; NARASIAH, K. S.; TALBOT, B. G. Active agents and mechanism of coagulation of turbid waters using Moringa oleifera. Water research. v. 29, n. 2, p. 703-710, 1995.

[25] NDABIGENGESERE, A.; NARASIAH, K. S. Quality of water treated by coagulation using Moringa oleifera seeds. Water research. v. 32, n.3, p. 781-791, 1998. 
[26] PAVANELLI, G. Eficiência de diferentes tipos de coagulantes na coagulação, floculação e sedimentação de água com cor ou turbidez elevada. Dissertação de mestrado. Escola de Engenharia de São Carlos, Universidade de São Paulo. São Carlos, 2001.

[27] PORTELLA, K.F. et al. Caraterização físico-química do lodo centrifugado da estação de tratamento de água. Passaúna - Curitiba - Pr. 22 CONGRESSO BRASILEIRO DE ENGENHARIA SANITÁRIA AMBIENTAL. Joinvile, 2003.

[28] PRITCHARD, M. et al. A study of the parameters affecting the effectiveness of Moringa oleifera in drinking water purification. Physics and Chemistry of the Earth, Reino Unido, v. 35, p.791-797, 2010.

[29] REVISTA ADITIVOS E INGREDIENTES. Amidos: Fontes, estruturas e propriedades funcionais. São Paulo: Insumos, ed. 63, ago. 2009.

[30] REVISTA ADITIVOS E INGREDIENTES. Polvilho azedo. São Paulo: Insumos, ed. 72, ago. 2010.

[31] SCHMITT, D. M. F. Tratamento de águas residuárias nas indústrias de laticínio pelos processos combinados coagulação/ floculação/ adsorção/ ultrafiltração utilizando semente de Moringa oleifera como coagulante. 2011. Dissertação de mestrado em Engenharia Química. Centro de Engenharias e Ciências Exatas, Universidade Estadual do Oeste do Paraná. Toledo, 2011.

[32] SOUZA, C. M. BRAGANÇA, M. G. Processamento artesanal da mandioca: fabricação do polvilho. Empresa de Assistência Técnica e Extensão Rural do Estado de Minas Gerais. 2000.

[33] VAZ, L. G. L. Processo de coagulação/floculação no tratamento de efluentes de galvanoplastia. Dissertação de mestrado. Departamento de Engenharia Química, Universidade Estadual do Oeste do Paraná. Toledo, 2009. 


\section{Capítulo 5}

Desenvolvimento de um Modelo Matemático para determinação do calor específico de soluções de leite/sacarose em função da temperatura $e$ da concentração

Rodrigo Rodrigues Evangelista

Maria Júlia Neves Martins

Thais Siqueira Tomasello

Walisson Guilhermitte Rodrigues

Gisandro Reis de Carvalho

Javier Telis Romero

Resumo: 0 leite é um fluido alimentício utilizado como base para a elaboração de alguns produtos, como por exemplo o leite condensado. Determinar as propriedades termofísicas, como o calor específico, é essencial para modelagem, desenho e controle das operações unitárias envolvidas na indústria de leite. Com isso objetivou-se determinar o calor específico de soluções leite/sacarose nas temperaturas de 10 a $80^{\circ} \mathrm{C}$ e fração de sólidos totais de 0,181 a 0,704 g de sólidos totais / g de solução de leite e sacarose por meio de calorimetria diferencial de varredura (DSC) e propor um modelo matemático que combine os efeitos da temperatura e fração de sólidos totais no calor específico. 0 calor específico variou de 2,682 a $3,736 \mathrm{~kJ} / \mathrm{kg}^{\circ} \mathrm{C}$ e o melhor ajuste foi o polinômio de segunda ordem com $\mathrm{RAdj}^{2}>0,98$ e $\mathrm{RQME}<1,0$. 


\section{INTRODUÇÃO}

A produção de leite no Brasil em 2018 totalizou um volume de 24.414 .313 mil litros, apresentado uma variação de $0,5 \%$, tendo como destaque as regiões Sul e Sudestes como principais produtoras do país, representando 77\% da produção total (Carvalho; Rocha; Carneiro, 2019). Além disto, o Brasil ocupou a terceira posição no ranking mundial de produção de leite em 2017, estando atrás da Índia (segunda posição) e Estados Unidos (primeira posição) (Resende; Leite; Stock; Nardy, 2019).

O leite condensado é um produto popularmente consumido no Brasil, presente como acompanhamento de frutas, sorvetes, bem como na elaboração de sobremesas em geral, além de estar presente em coquetéis sofisticados (podendo ser alcóolicos ou não), dentre outras aplicações. 0 leite condensado pode ser descrito como um leite concentrado por evaporação, o qual adiciona-se açúcar com a funcionalidade de reduzir volume e aumentar a conservação do produto, tendo como resultado um produto cuja coloração é amarelada (Mohameed; ABU-Jdayil; Eassa, 2006).

Dados relatados pela Companhia Nacional de Abastecimento (Conab), relataram que no balanço de lácteos realizado até fevereiro de 2019 os três principais produtos importados foram leite pó integral, leite em pó desnatado e queijo tipo muçarela. Em contrapartida, às exportações brasileiras de produtos lácteos neste mesmo período destacaram os três principais produtos sendo eles outros leites, creme de leite/leite condensado $(31,1 \%$ do total exportado), outros cremes de leite $(24,5 \%$ do total exportado) e queijos fundidos (10\% do total exportado) (CONAB, 2019).

A determinação das propriedades físicas dos alimentos, como calor específico por exemplo, é de extrema importância para o dimensionamento de tratamentos térmicos que são empregados na indústria de alimentos. Além disso, o conhecimento das propriedades físicas permite avaliar otimização e simulação de processos que são empregados nas indústrias, principalmente quando se empregam análises de custos, segurança alimentar e qualidade dos produtos quando o principal elemento é avaliado Costa; Silva; Vieira, 2018).

Diante do exposto o trabalho objetivou determinar o calor específico de soluções leite e sacarose em diferentes temperaturas e concentrações, bem como verificar a influências destas variáveis sob a propriedade física de estudo, além de propor um modelo matemático que melhor descreve os dados do calor específico como uma função de temperatura e concentração.

\section{MATERIAL E MÉTODOS}

\subsection{MATERIAL}

Para a preparação das amostras foram adquiridos 24 litros de leite semidesnatado pasteurizado e $20 \mathrm{~kg}$ de açúcar cristal, obtidos em comércio local de São José do Rio Preto, São Paulo, Brasil. Ambos materiais foram obtidos de mesmo lote, sendo estes homogeneizados.

\subsection{COMPOSIÇÃO QUÍMICA DO LEITE}

A umidade da amostra foi determinada pelo método gravimétrico por secagem em estufa a $105^{\circ} \mathrm{C}$ até peso constante (IAL, 2008, p. 1020 - método 012/IV); o conteúdo de lipídeos foi avaliado pela leitura direta do percentual de gordura através do butirômetro de Gerber (AOAC, 2005 - método 2000.18); o teor de proteínas foi determinado pelo método de Kjedahl (AOAC, 2005 - método 991.20); o conteúdo de cinzas foi determinado através de incineração na mufla (AOAC, 2005 - método 935.42) e por fim o conteúdo de carboidratos foi determinado por diferença.

\subsection{PREPARAÇÃO DAS AMOSTRAS}

Foram preparadas 11 diferentes amostras da solução leite/sacarose em diferentes concentrações de sólidos totais e água, variando aproximadamente de $82 \%$ a $30 \%$ de água (g / 100g de amostra), que simulam as concentrações empregados no processo de leite condensado, conforme reportado na Tabela 2. Para o preparo destas amostras as soluções de leite/sacarose foram concentradas em um evaporador rotativo a baixa pressão (Marconi MA 120/TH). As misturas leite/sacarose foram submetidas a diferentes etapas de evaporação obtendo-se diferentes composições determinadas a partir de balanços de massa conforme reportado na Tabela 2. 


\subsection{DETERMINAÇÃO DO CALOR ESPECÍFICO}

O calor específico $\left(\mathrm{c}_{\mathrm{p}}, \mathrm{kJ} / \mathrm{kg} .{ }^{\circ} \mathrm{C}\right)$ foi determinado por calorimetria diferencial de varredura utilizando DSC 8000 (Perkin Elmer, Shelton, USA), nas composições apresentadas na Tabela 2 em uma ampla faixa de temperatura que simula o processamento de leite condensado $\left(10,20,30,40,50,60,70\right.$ e $\left.80^{\circ} \mathrm{C}\right) .0$ equipamento DSC foi previamente calibrado com Índio (T.f $156,6^{\circ} \mathrm{C}, \Delta \mathrm{Hf}=28,45 \mathrm{~kJ} / \mathrm{kg}$ ) a uma taxa de aquecimento de $10{ }^{\circ} \mathrm{C} / \mathrm{min}$. Gás nitrogênio $(99,5 \%$ de pureza) foi usado como gás de purga a um fluxo de aproximadamente $20 \mathrm{~mL} / \mathrm{min}$. Panelas de alumínio para líquidos voláteis 24,01 \pm 0,04 $\mathrm{mg}$ (ref 0219-0062, Perkin Elmer, USA) foram usadas como linha base e como porta amostra do material de referência (ARCHED, 1993), discos de safira sintética de 3 mm de diâmetro (ref 0219-1268, Perkin Elmer, Shelton, USA), assim como as amostras leite/sacarose. Foram utilizadas $5 \mu \mathrm{L}$ de amostra, sendo acondicionadas nas panelas de alumínio, o qual foram seladas e pesadas antes de cada procedimento experimental. A linha base, material de referência e amostras foram submetidas ao seguinte programa de temperatura: isotérmico a $0^{\circ} \mathrm{C}$ por $4 \mathrm{~min}$, taxa de aquecimento a $10^{\circ} \mathrm{C} / \mathrm{min}$ até $56^{\circ} \mathrm{C}$ e isotérmico a $56^{\circ} \mathrm{C}$ por $4 \mathrm{~min}$, de acordo com a metodologia empregada pela ASTM International (ASTM E1269, 2005). 0 software PYRIS 11.0 (Perkin Elmer, Shelton, USA) foi usado para analisar os dados. O calor específico das misturas leite/sacarose foi calculado de acordo com a Equação 1:

$$
c_{p}=\frac{D_{s}}{W_{s} \theta}
$$

onde $\mathrm{D}_{\mathrm{s}}$ é a potência térmica do respectivo material de referência em determinada temperatura $(\mathrm{mW}), \mathrm{W}_{\mathrm{s}}$ é a massa da amostra (mg) e $\theta$ representa a taxa de aquecimento $\left({ }^{\circ} \mathrm{C} / \mathrm{min}\right)$.

\subsection{MODELAGEM E ANÁLISE ESTATÍSTICA DOS DADOS}

Foram empregados modelos polinomiais de primeira e segunda ordem para representarem o calor específico das soluções de leite/sacarose como função da temperatura e concentração, a Equação 2 representa o modelo de um polinômio de segunda ordem. Para tal análise regressões não lineares foram empregadas utilizando o software Statistica 7.0 (StatSoft, Inc.).

$$
c_{p}=\alpha_{0}+\alpha_{1} T+\alpha_{2} X+\alpha_{3} T^{2}+\alpha_{4} X^{2}
$$

onde $c_{p}$ representa o calor específico $\left(\mathrm{kJ} / \mathrm{kg} .{ }^{\circ} \mathrm{C}\right), \alpha_{i}$ constantes empíricas do modelo, $T$ representa a temperatura $\left({ }^{\circ} \mathrm{C}\right.$ ) e $X$ a fração mássica de sólidos totais ( $\mathrm{g}$ de sólidos totais / $\mathrm{g}$ de solução leite e sacarose).

A escolha do melhor modelo será realizada pela avaliação do maior coeficiente de determinação ajustado $\left(\mathrm{R}_{\mathrm{Adj}}{ }^{2}\right)$ e pela minimização da raiz quadrada do erro médio (RQME), sendo este determinado pela Equação 3.

$$
R Q M E=\sqrt{\frac{1}{n} \sum_{i=1}^{n}\left(C p_{\text {Experimental }}-C p_{\text {Predito }}\right)^{2}}
$$

onde $C p_{\text {Experimental }}$ representa do calor específico determinado experimentalmente $\left(\mathrm{kJ} / \mathrm{kg} .{ }^{\circ} \mathrm{C}\right)$, $C p_{\text {Predito }}$ o calor específico determinado pelo modelo e $n$ o número de pontos experimentais.

\section{RESULTADOS E DISCUSSÃO}

A composição química do leite semidesnatado pasteurizado está apresentada na Tabela 1 com as respectivas repetições. 
Tabela 1 - Composição química de leite semidesnatado pasteurizado e homogeneizado.

\begin{tabular}{|c|c|c|c|c|c|c|c|c|c|c|}
\hline & \multicolumn{1}{c}{ Amostras } \\
Componentes & 1 & 2 & 3 & 4 & 5 & 6 & 7 & 8 & Média & SD \\
\hline Água & 89,053 & 88,983 & 89,388 & 88,726 & 88,919 & 88,913 & 88,333 & 89,583 & 89,575 & 0,436 \\
\hline Proteína & 3,748 & 3,728 & 3,741 & 3,714 & 3,704 & 3,708 & 3,687 & 3,849 & 3,849 & 0,065 \\
\hline Carboidrato & 4,592 & 4,680 & 4,276 & 4,959 & 4,767 & 4,770 & 5,395 & 3,944 & 3,946 & 0,505 \\
\hline Gordura & 1,668 & 1,667 & 1,658 & 1,663 & 1,669 & 1,668 & 1,649 & 1,686 & 1,686 & 0,013 \\
\hline Cinzas & 0,940 & 0,943 & 0,937 & 0,939 & 0,941 & 0,941 & 0,936 & 0,938 & 0,944 & 0,003 \\
\hline
\end{tabular}

A Tabela 2 mostra a composição a química das misturas de leite/sacarose obtidas após o processo de evaporação.

Tabela 2 - Composição química das misturas de leite/sacarose após processo de evaporação.

\begin{tabular}{|c|c|c|c|c|c|}
\hline \multicolumn{1}{|c|}{ Amostra } & Água & Proteína & Carboidratos & Gordura & \multicolumn{1}{c|}{ Cinzas } \\
\hline 1 & 81,928 & 3,447 & 12,225 & 1,535 & 0,865 \\
\hline 2 & 77,568 & 4,297 & 15,174 & 1,905 & 1,074 \\
\hline 3 & 74,279 & 4,906 & 17,399 & 2,184 & 1,231 \\
\hline 4 & 70,512 & 5,625 & 19,947 & 2,504 & 1,411 \\
\hline 5 & 66,163 & 6,455 & 22,889 & 2,873 & 1,619 \\
\hline 6 & 61,588 & 7,328 & 25,984 & 3,261 & 1,838 \\
\hline 7 & 56,726 & 8,256 & 29,273 & 3,674 & 2,071 \\
\hline 8 & 50,856 & 9,376 & 33,244 & 4,172 & 2,352 \\
\hline 9 & 45,003 & 10,493 & 37,203 & 4,669 & 2,632 \\
\hline 10 & 37,591 & 11,907 & 42,217 & 5,298 & 2,987 \\
\hline 11 & 29,622 & 13,427 & 47,608 & 5,974 & 3,368 \\
\hline
\end{tabular}

0 método calorimétrico diferencial de varredura foi aplicado para determinação do calor específico de soluções de leite/sacarose na faixa de temperatura de 10 a $80^{\circ} \mathrm{C}$ e fração de sólidos totais de 0,181 a 0,704 g sólidos totais / g de solução leite e sacarose. Os valores de calor específico vaiaram de $2,682 \mathrm{~kJ} / \mathrm{kg}^{\circ} \mathrm{C}$ $\left(10^{\circ} \mathrm{C}\right.$ e $0,704 \mathrm{~g}$ sólidos totais / $\mathrm{g}$ de solução leite e sacarose) a $3,736 \mathrm{~kJ} / \mathrm{kg}^{\circ} \mathrm{C}\left(50^{\circ} \mathrm{C}\right.$ e $0,181 \mathrm{~g}$ sólidos totais / g de solução leite e sacarose). Os resultados indicaram que o aumento da fração de sólidos proporcionou redução do calor específico, enquanto em uma mesma concentração o calor específico aumentou com o aumento da temperatura.

Dados na literatura sobre propriedades físicas de soluções de leite/sacarose são escassos, no entanto há inúmeros resultados reportando sobre propriedades físicas de leite de diferentes tipos, bem como a modelagem das propriedades físicas em função da temperatura e composição química. Minim et al. (2002), estudaram a influência da temperatura e do conteúdo de gordura nas propriedades físicas de leite bovino e reportaram que o calor específico variou de 3,4 a 4,1 kJ/ $\mathrm{kg}^{\circ} \mathrm{C}$, desta forma observou-se que os valores encontrados de calor específico no presente estudo estão de acordo com os reportados pelos autores.

Foram empregados modelos empíricos polinomiais de primeira e segunda ordem para descrever os dados do calor específico como função da temperatura e fração de sólidos totais. Os resultados destas regressões estão apresentados na Figuras 1(A) e 1(B), respectivamente, bem como na Tabela 3. 
Figura 1 - Gráficos do calor específico em função da temperatura e fração de sólidos totais para solução de leite/sacarose ajustados aos modelos (A) linear e (B) quadrático.
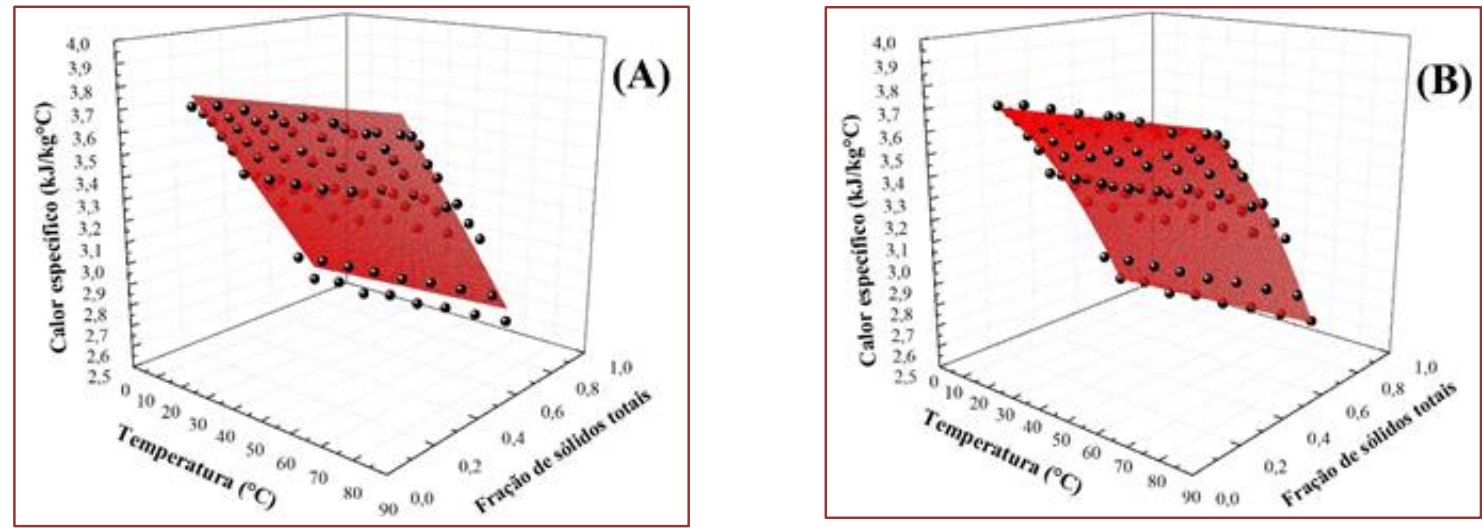

Tabela 3 - Ajustes dos parâmetros da regressão não linear referente à Equação (2).

\begin{tabular}{|c|c|c|}
\hline Constantes & Polinômio de $1^{\circ}$ Grau & $\begin{array}{c}\text { Polinômio de } 2^{\circ} \\
\text { Grau }\end{array}$ \\
\hline$\alpha_{0}$ & 4,082 & 3,831 \\
\hline$\alpha_{1}$ & 0,001 & 0,001 \\
\hline$\alpha_{2}$ & $-1,904$ & $-0,559$ \\
\hline$\alpha_{3}$ & 0 & $5,40 \times 10^{-7}$ \\
\hline$\alpha_{4}$ & 0 & $-1,541$ \\
\hline $\mathrm{R}_{\mathrm{Adj}}{ }^{2}$ & 0,971 & 0,985 \\
\hline $\mathrm{RQME}$ & 0,053 & 0,038 \\
\hline
\end{tabular}

Ambos modelos polinomiais de primeira e segunda ordem apresentaram elevados coeficientes de determinação e baixos RQME, no entanto de acordo com os resultados apresentados na Tabela 3, observou-se que o modelo polinomial de segunda ordem melhor descreveu os dados experimentais do calor específico em função da temperatura e fração de sólidos totais, contudo está em contraste com o reportado por Minim et al. (2002), que empregaram modelo polinomial de ordem para descrever as propriedades físicas de leite bovino nas diferentes temperaturas e conteúdo de gordura e com Tansakul e Chaisawang (2006), que empregaram modelo polinomial de primeira ordem para descrever as propriedades físicas de leite de coco.

O conhecimento do calor específico em diferentes temperaturas e frações de sólidos totais, bem como a modelos matemáticos empíricos que descrevam o comportamento destes dados são de extrema importância no dimensionamento de processos que envolvam tratamentos térmicos, como pasteurização por exemplo, ou processos de concentração, como a evaporação. Pois com a modelagem destes dados é possível realizar otimização e simulação de processos, de modo a conferir melhor segurança alimentar aos consumidores, bem como atendimento aos padrões de qualidade do produto.

\section{CONCLUSÃO}

Conclui-se que o leite durante o processo de evaporação apresentou a redução dos compostos químicos sendo um comportamento já esperado durante este tipo de processamento. 0 calor específico das amostras de leite nas amplas faixas de temperatura e fração de sólidos totais foram de 2,682 a 3,736 $\mathrm{kJ} / \mathrm{kg}^{\circ} \mathrm{C}$. Entre ambos modelos testados o polinômio de segunda ordem apresentou melhor ajuste com RAdj2 $=0,985$ e RQME $=0,038$. 0 fato de se obter equações que determinam o calor específico do leite/sacarose faz com que as empresas tenham maior agilidade e segurança durante o desenvolvimento de equipamentos e projetos. 


\section{REFERÊNCIAS}

[1] AOAC. Association of official analytical chemists. Official methods of analysis of AOAC international, (18th ed.). Maryland, USA: AOAC International, 2005.

[2] ARCHED, D. G. 1993. Thermodynamic properties of synthetic sapphire ( $\alpha$-A1203) standard reference material 720 and the effect of temperature-scale differences on thermodynamic properties. J Phys Chem Ref Data, v. 22, p. 1441-1453.

[3] ASTM E1269. Standart test method for determining specific heat capacity by differentail scanning calorimetry. West Conshohocken: ASTM International. 2005.

[4] Carvalho, G. R.; Rocha, D. T. da; Carneiro, A. V. Indicadores: Leites e Derivados. v. 10, n. 91, p. 16, 2019. Disponível em <https://ainfo.cnptia.embrapa.br/digital/bitstream/item/198370/1/2019-06-Indicadores-leite.pdf>

[5] CONAB. Análise Mensal - Leites e Derivados: Fevereiro de 2019.

[6] Costa, H. C. B.; SILVA, D. O.; Vieira, L. G. M. Physical properties of açai-berry pulp and kinetics study of its anthocyanin thermal degradation. Journal of Food Engineering, v. 239, p. 104-113, 2018.

[7] IAL. Métodos físico-químicos para análise de alimentos. Instituto Adolfo Lutz. (4 ed.), 2008. São Paulo: Instituto Adolfo Lutz.

[8] Minim, A. L.; Coimbra, S. R. J.; Minim, P. R. V.; Romero, T. J. Influence of Temperature and Water and Fat Contents on the Thermophysical Properties of Milk. Journal Of Chemical And Engineering, v. 47, p. 1488-1491, 2002.

[9] Mohameed, H. A.; Abu-Jdayil, B.; Eassa, A. M. Flow properties of corn starch-milk-sugar system prepared at 368.15 K. Journal of Food Engineering, v. 77, n. 4, p. 958-964, 2006.

[10] Tansakul, A.; Chaisawang, P. Thermophysical properties of coconut milk. Journal of Food Engineering, v. 73, p. 276-280, 2006.

[11] Resende, J. C. de; Leite, J. L. B.; STOCK, L. A.; Nardy, V. P. D. R. Anuário Leite 2019. 


\section{Capítulo 6}

Densidade e condutividade térmica de soluções de leite/sacarose em função da temperatura e teor de sólidos totais

\section{Marcio Augusto Ribeiro Sanches \\ Bianca Guimarães \\ Walisson Guilhermitte Rodrigues \\ Thais Siqueira Tomasello \\ Tiago Carregari Polachini \\ Javier Telis Romero}

Resumo: 0 leite possui importância econômica mundial, pois além de ser consumido em sua forma original, também é matéria prima para a produção de leite condensado, leite em pó, doces e outros alimentos. A partir disso, conhecer como as propriedades físicas, em especial a densidade e a condutividade térmica, de misturas de leite/sacarose variam em função da sua concentração e temperatura é de extrema importância para o controle de parâmetros e processos na indústria alimentícia. Dessa forma, este estudo traz uma análise dos dados experimentais de 11 amostras de leite/sacarose em diferentes concentrações de sólidos totais a partir de amostras iniciais com 81\% em peso de água e $19 \%$ de sólidos totais em 8 temperaturas diferentes $\left(10\right.$ a $\left.80{ }^{\circ} \mathrm{C}\right) .0$ procedimento para a obtenção dessas concentrações foi realizado utilizando um Evaporador Rotativo a Vácuo. As misturas de leite/sacarose foram submetidas a diferentes etapas de evaporação e por meio de cálculos de balanços de massa, foi possível obter as diferentes composições. A densidade e a condutividade térmica das soluções de leite/sacarose mostraram dependência da temperatura e do teor de sólidos totais e isso pôde ser visto matematicamente por meio de modelos de primeira e segunda ordem. Ambos os modelos apresentaram ajustes satisfatórios, sendo os melhores ajustes para o modelo de primeira ordem. 


\section{INTRODUÇÃO}

O leite é um dos alimentos mais consumidos no mundo. Estima-se que em 2019 a sua produção mundial será de aproximadamente 513 milhões de toneladas, o que sugere um aumento de 1,5\% em relação a 2018 (USDA, 2019). Só os EUA e a Índia detêm cerca de 60\% dessa produção mundial e o Brasil cerca de 5\%. Isso o torna um dos maiores produtores mundiais de leite e o maior da América Latina (32.380 mil toneladas produzidas) (USDA, 2019).

O leite cru é um produto que geralmente passa por processos de aquecimento visando alcançar os níveis de segurança indispensáveis para o consumo humano e que resulta na extensão de sua vida útil. 0 processo de aquecimento é uma das etapas importantes na produção de leite e seus derivados e que envolve a remoção de água do leite (Markoska; Huppertz; Grewal; Vasiljevic, 2019).

Os três produtos lácteos mais exportados, no Brasil, até outubro de 2019 foram: outros leites, cremes de leite/leite condensado $(30,0 \%$ do valor total exportado); outros cremes de leite $(24,7 \%$ do valor total exportado) e queijos fundidos ( $8,3 \%$ do valor total exportado). Os outros trinta e quatro derivados lácteos complementaram o valor total das exportações brasileiras de lácteos em 2019, até outubro (Conab, 2019).

O processamento de outros leites (leite em pó) e também de leite condensado, em escala industrial, requer algumas propriedades do leite. Essas propriedades (densidade, viscosidade, calor específico, condutividade térmica, entre outras) se encontram na literatura, no entanto, as propriedades da mistura de leite em diferentes concentrações de sacarose, merece um maior aprofundamento. Isso, porque o conhecimento dessas propriedades desperta um grande interesse na indústria de produtos concentrados de leite para o projeto, simulação, otimização e operações unitárias como a evaporação e trocadores de calor (Azoubel et al., 2005).

Este trabalho foca em duas dessas propriedades físicas que são a densidade e a condutividade térmica. Determinar essas propriedades baseado em fundamentos teóricos não é simples, pois os alimentos possuem matrizes de grande complexidade. Dessa forma, modelos empíricos podem ser mais precisos por levar em consideração a estrutura do alimento (Minim et al., 2002).

A densidade do leite é uma relação entre seu peso e volume. Através dela é possível avaliar a relação entre os sólidos e o solvente no leite, utilizado juntamente com o teste de gordura para determinar o teor de sólidos do leite (Venturini; Sarcinelli; Silva, 2007). Já a condutividade térmica é considerada a propriedade mais importante no processamento térmico a altas e baixas temperaturas e há uma correlação entre a viscosidade aparente e a condutividade térmica porque a taxa de cisalhamento está relacionada à condutividade térmica e essas duas variáveis variam com a composição e a temperatura intrínsecas (Pereira; Rezende; Giarola., 2014).

Assim sendo, o objetivo deste trabalho foi determinar como a temperatura $\left(10\right.$ a $\left.80^{\circ} \mathrm{C}\right)$ e o teor de sólidos totais (19\% a $60 \%$ de sólidos) afetam as propriedades termofísicas do leite/sacarose como a densidade e a condutividade térmica, bem como propor modelos simples de aplicações práticas.

\section{MATERIAIS E MÉTODOS}

\subsection{MATÉRIA-PRIMA}

Para a realização dos experimentos foram adquiridos 24 litros de leite semidesnatado, pasteurizados e homogeneizados e 20 quilogramas de açúcar cristal em um supermercado local da cidade de São José do Rio Preto - SP. Composição química

As análises de composição química foram realizadas nas amostras de leite semidesnatado. 0 teor de umidade foi determinado gravimetricamente por secagem em estufa a $105^{\circ} \mathrm{C}$ até peso constante (IAL, 2008, p. 1020 - método 012 / IV); o conteúdo lipídico foi avaliado através da leitura direta da porcentagem de gordura através do butirômetro Gerber (AOAC, 2005 - método 2000.18); o teor de proteína foi determinado pelo método de Kjedahl (AOAC, 2005 - método 991.20). 0 conteúdo de cinzas foi determinado por incineração de mufla (AOAC, 2005 - método 935.42) e o teor de carboidratos foi calculado por diferença. Todas as análises foram realizadas em triplicata.

\subsection{PROCESSO DE EVAPORAÇÃO}

Foram preparadas 11 amostras de leite/sacarose com diferentes concentrações a partir de amostras iniciais com $92 \%$ em peso de leite semidesnatado e $8 \%$ de sacarose. 0 procedimento para a obtenção 
dessas concentrações foi realizado utilizando um evaporador rotativo a vácuo, marca MARCONI, modelo MA120/TH, com capacidade até $2500 \mathrm{~mL}$. As misturas de leite/sacarose foram submetidas a diferentes etapas de evaporação obtendo-se diferentes composições, sendo determinadas a partir de balanços de massa.

\section{3 DETERMINAÇÃO DA DENSIDADE}

As densidades das misturas de leite/sacarose após os processos de evaporação foram determinadas em triplicata utilizando um densímetro eletrônico digital (modelo DMA 4500-M, Anton Paar, Áustria) nas temperaturas de $10,20,30,40,50,60$ e $70^{\circ} \mathrm{C}$. Foram inseridos aproximadamente $50 \mathrm{~mL}$ de cada amostra para medições de densidade. 0 desempenho do equipamento foi avaliado utilizando solução aquosa de ácido acético (50:50 v / v) utilizando densidades conhecidas como descritas por Perry \& Chilton (1986).

\subsection{DETERMINAÇÃO DA CONDUTIVIDADE TÉRMICA}

A condutividade térmica das soluções de leite/sacarose foram determinadas de acordo com o arranjo experimental descrito por Castilhos et al. (2017) nas temperaturas de 10, 20, 30, 40, 50, 60 e $70^{\circ} \mathrm{C}$, sendo calculada a partir da equação de transferência de calor radial unidirecional (Equação 1), conforme descrito pela equação de Fourier em coordenadas cilíndricas com as condições de contorno correspondentes à transferência entre as duas superfícies cilíndricas concêntricas mantidas a temperaturas constantes e considerando que o calor fornecido pela resistência térmica $(q)(W)$ foi igual ao calor que passou pelo suco:

$$
k=q \frac{\ln \frac{R_{1}}{R_{5}}}{2 \pi L\left(T_{5}-T_{1}\right)}
$$

Em que $L$ é o comprimento da célula (m), $R_{1}$ e $R_{5}$ são as posições radiais (m) do termopar mais próximo para a resistência térmica e o termopar mais próximo à superfície interna da célula, respectivamente, e $T_{1}$ e $T_{5}$ são as temperaturas de estado estacionário $\left({ }^{\circ} \mathrm{C}\right)$ a $R_{1}$ e $R_{5}$, respectivamente.

\subsection{MODELAGEM MATEMÁTICA}

Os resultados de densidade das misturas de leite/sacarose foram ajustados a modelos empíricos de primeira e segunda ordem em função da concentração e temperatura.

\subsection{ANÁLISE ESTATÍSTICA}

0 ajuste do coeficiente de correlação $\left(R^{2} a d j\right)$ e o erro médio relativo $(M R E)$ foram usados para verificar a eficiência do ajuste dos modelos aos dados experimentais e suas respectivas fórmulas são mostradas nas Equações 2 e 3 (Castell-Palou et al., 2012).

$$
\begin{aligned}
& R_{a d j}^{2}=1-\frac{S_{d x}^{2}}{S_{d}^{2}} \\
& \operatorname{MRE}(\%)=\frac{100}{n} \sum_{i-1}^{n} \frac{\left|D_{\text {exp }}-D_{\text {pred }}\right|}{D_{\text {exp }}}
\end{aligned}
$$

\section{RESULTADOS E DISCUSSÃO}

O leite é composto de água e é nessa porção que encontram dispersos os componentes sólidos, denominados sólidos totais. Os sólidos totais são constituídos de proteínas, gorduras, carboidratos e sais (Venturini; Sarcinelli; Silva, 2007). 
A composição do leite semidesnatado com 8 repetições encontra-se na Tabela 1, juntamente com a média seguida do desvio padrão. Já a Tabela 2 mostra a composição química das misturas de leite/sacarose obtidas após o processo de evaporação.

Tabela 1. Composição de leite semidesnatado pasteurizado e homogeneizado.

\begin{tabular}{|lc|c|c|c|c|c|c|c|c|c|c|}
\multicolumn{1}{c}{\begin{tabular}{c} 
Componentes \\
\multicolumn{1}{c}{$(\%)$}
\end{tabular}} & 1 & 2 & 3 & 4 & 5 & 6 & 7 & 8 & Media & Sy \\
\hline Água & 89,58 & 89,58 & 88,33 & 88,91 & 88,92 & 88,73 & 89,39 & 88,98 & 89,05 & 0,44 \\
\hline Proteína & 3,849 & 3,849 & 3,687 & 3,708 & 3,704 & 3,714 & 3,714 & 3,728 & 3,747 & 0,07 \\
\hline Carboidratos & 3,946 & 3,944 & 5,395 & 4,77 & 4,767 & 4,959 & 4,276 & 4,68 & 4,592 & 0,51 \\
\hline Gordura & 1,686 & 1,868 & 1,649 & 1,668 & 1,669 & 1,663 & 1,658 & 1,667 & 1,668 & 0,01 \\
\hline Cinzas & 0,944 & 0,938 & 0,936 & 0,941 & 0,941 & 0,939 & 0,937 & 0,943 & 0,94 & 0 \\
\hline
\end{tabular}

Tabela 2. Composição química das misturas de leite/sacarose obtidas após o processo de evaporação.

\begin{tabular}{|c|c|c|c|c|c|}
\hline Cinzas & Gordura & Carboidratos & Proteína & Água & Amostra \\
\hline 0,865 & 2,166 & 12,225 & 3,448 & 81,297 & 1 \\
\hline 0,911 & 2,282 & 12,878 & 3,632 & 80,298 & 2 \\
\hline 1,018 & 2,551 & 14,395 & 4,06 & 77,976 & 3 \\
\hline 1,153 & 2,889 & 16,302 & 4,597 & 75,059 & 4 \\
\hline 1,331 & 3,335 & 18,817 & 5,307 & 71,211 & 5 \\
\hline 1,526 & 3,824 & 21,575 & 6,085 & 66,991 & 6 \\
\hline 1,574 & 3,944 & 22,258 & 6,277 & 65,946 & 7 \\
\hline 1,731 & 4,337 & 24,471 & 6,901 & 62,561 & 8 \\
\hline 1,925 & 4,824 & 27,22 & 7,676 & 58,355 & 9 \\
\hline 2,47 & 6,189 & 34,925 & 9,849 & 46,566 & 10 \\
\hline 2,771 & 6,942 & 39,173 & 11,047 & 40,067 & 11 \\
\hline
\end{tabular}

As propriedades termofísicas como a densidade e a condutividade térmica de uma solução podem ser influenciadas por fatores como mudanças de temperatura e concentração de sólidos.

O efeito das diferentes temperaturas e de teor de sólidos totais sobre a densidade das misturas de leite/sacarose é mostrado nas Figuras 1 e 2.

As densidades das soluções de leite/sacarose variaram de $1078,4 \mathrm{~kg} / \mathrm{m}^{3}$ (18,70\% Sólidos totais e $\left.80^{\circ} \mathrm{C}\right)$ a $1270,9 \mathrm{~kg} / \mathrm{m}^{3}\left(59,93\right.$ Sólidos totais e $\left.10^{\circ} \mathrm{C}\right)$. 0 aumento da temperatura promoveu a redução das densidades das soluções de sacarose considerando uma mesma concentração. Isso pode ser explicado pelo fato de a temperatura causar um aumento do volume molecular, gerando uma diminuição da densidade. Entretanto, quando há um aumento da concentração em uma mesma temperatura, a densidade também aumenta, pois pode estar diretamente relacionada com o aumento no teor de sólidos totais na amostra (Castilhos et al., 2017). Para leite em pós de vaca e de camelo, foi observado comportamento semelhante em que a densidade aumentou com a desnatação (remoção da gordura do leite), aumentando o nível total de sólidos do leite (Habtegebriel et al., 2018). 
Figura 1. Comportamento da densidade de soluções de leite/sacarose em função da temperatura e teor de sólidos totais: Modelo de $1^{\circ}$ ordem.

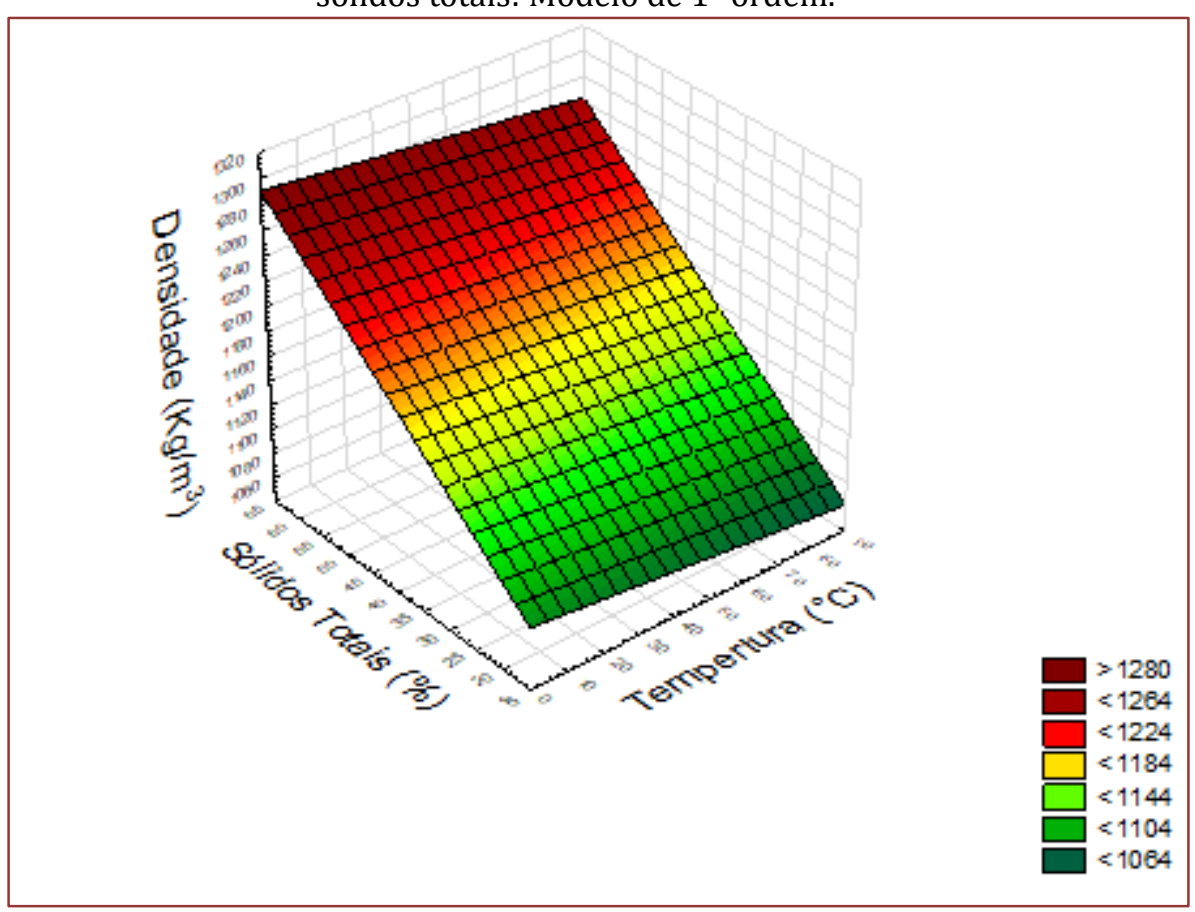

Figura 2. Comportamento da densidade de soluções de leite/sacarose em função da temperatura e teor de sólidos totais: Modelo de $2^{\circ}$ ordem.

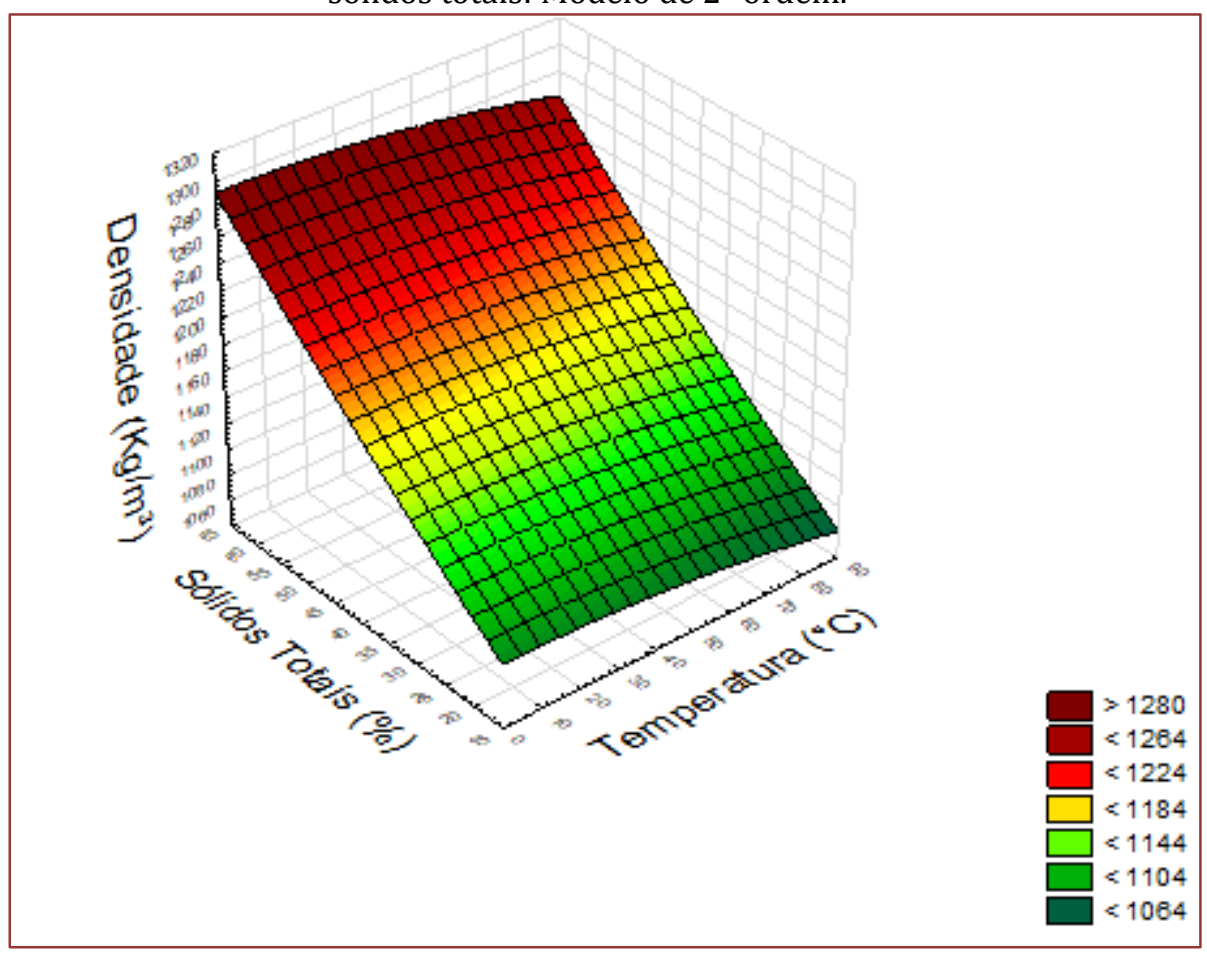


Os resultados de densidade das misturas de leite/sacarose foram ajustados a modelos empíricos de primeira e segunda ordem em função da concentração e temperatura (Equações 4 e 5, respectivamente).

$$
\begin{aligned}
& \rho=1030,2389-0,3164 T+4,0106 S_{T} \\
& \rho=1036,9783+0,0177 T+3,2699 S_{T}-0,0035 T^{2}-0,0006 T S_{T}+0,0101 S_{T}^{2}
\end{aligned}
$$

Em que $\rho$ é a densidade em $\mathrm{Kg} / \mathrm{m}^{3}, T$ é a temperatura em ${ }^{\circ} \mathrm{C}$ e $S_{T}$ é o teor de sólidos totais em \%.

Os resultados mostraram que os dois modelos testados obtiveram ajustes satisfatórios apresentando valores de ajuste com $\mathrm{R}^{2}>0,9929$. 0 modelo de primeira ordem devido à sua simplicidade é de melhor utilização e compreensão. Além disso, o menor erro relativo foi observado no modelo de primeira ordem $(0,016 \%)$, indicando que a densidade das soluções de leite/sacarose foram melhor ajustadas a este modelo.

O comportamento da condutividade térmica em função de diferentes temperaturas e de teor de sólidos totais é mostrado nas Figuras 3 e 4.

A condutividade térmica variou de $0,6510\left(18,70 \%\right.$ de sólidos solúveis e $\left.80{ }^{\circ} \mathrm{C}\right)$ a $0,4230 \mathrm{~W} \cdot \mathrm{m}^{-1}{ }^{\circ} \mathrm{C}$ ${ }^{1}\left(59,93 \%\right.$ de sólidos solúveis e $\left.10^{\circ} \mathrm{C}\right)$. O aumento da temperatura promoveu um aumento da condutividade térmica considerando uma mesma concentração (Lin et al., 2003). Entretanto, quando há um aumento da concentração de sólidos em uma mesma temperatura, a condutividade térmica tende a diminuir (Zainal et al., 2000; Munir et al., 2016).

Os leites fermentados e as bebidas lácteas fermentadas apresentam valores mais altos de condutividade térmica, relacionados ao seu teor de água. A água é o componente alimentar que mais contribui para o aumento da condutividade (Minim et al., 2002; Pereira et al., 2013; Gonçalves et al., 2017).

Figura 3. Comportamento da condutividade térmica de soluções de leite/sacarose em função da temperatura e teor de sólidos totais: Modelo de $1^{\circ}$ ordem.

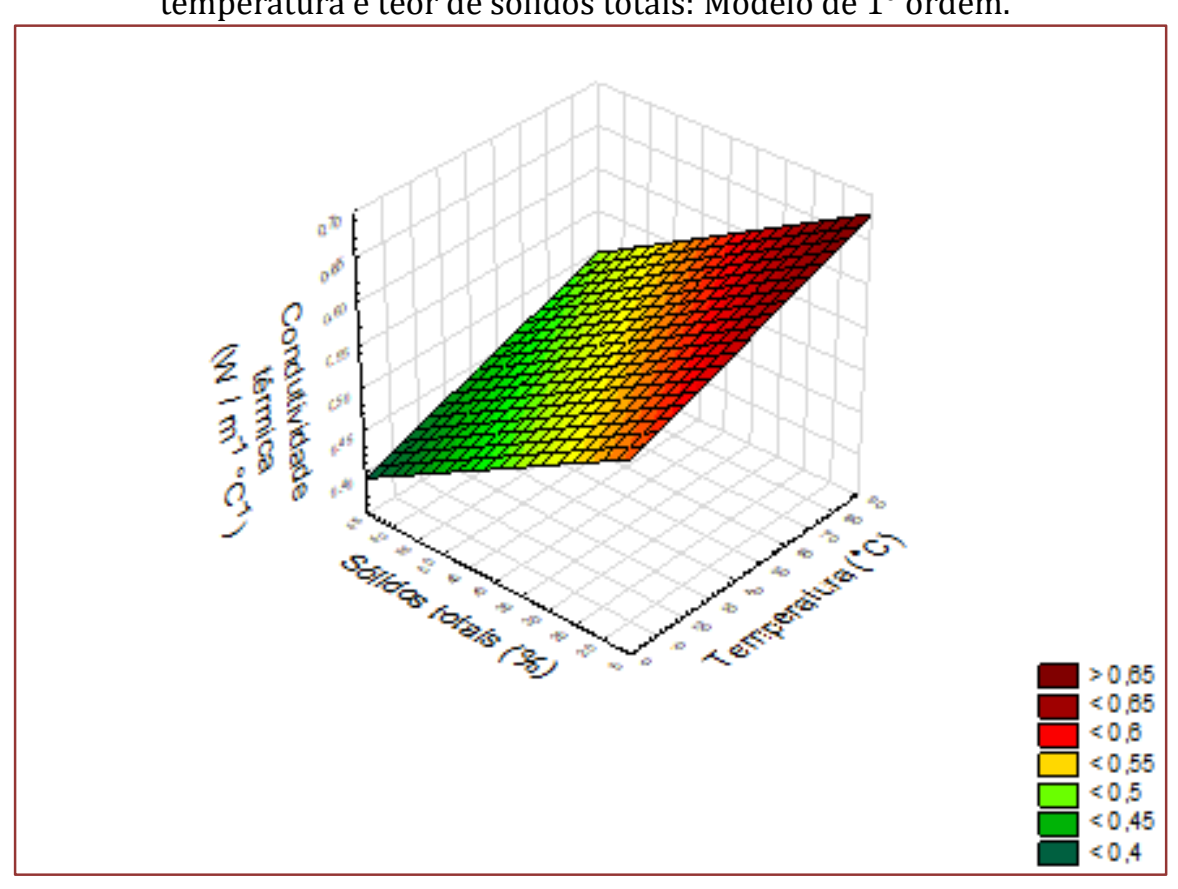


Figura 4. Comportamento da condutividade térmica de soluções de leite/sacarose em função da temperatura e teor de sólidos totais: Modelo de $2^{\circ}$ ordem.

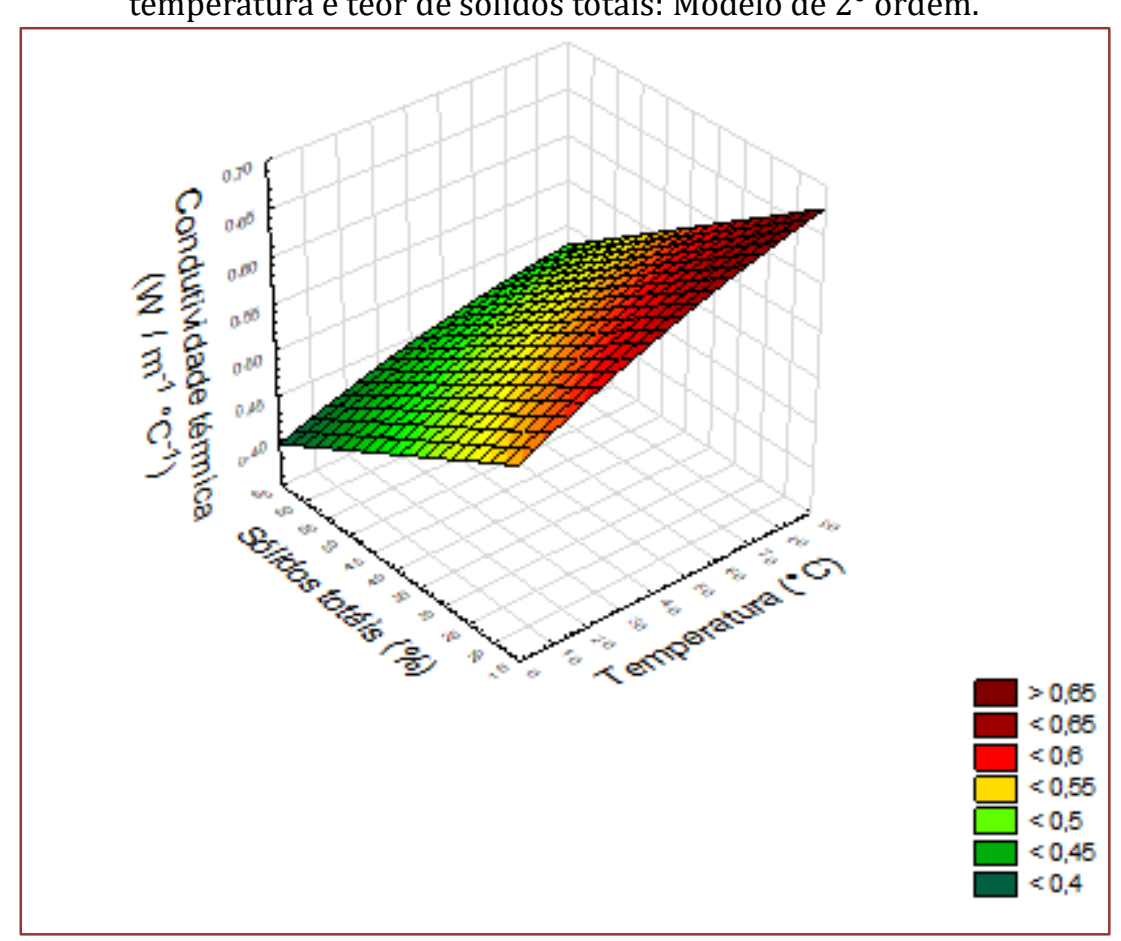

Os resultados da condutividade térmica das misturas de leite/sacarose foram ajustados a modelos empíricos de primeira e segunda ordem em função da concentração e temperatura (Equações 6 e 7).

$k=0,6283+0,0012 T-0,0036 S_{T}$

$k=0,6067+0,002 T-0,0032 S_{T}-5,7592 \cdot 10^{-6} T^{2}-8,4399 \cdot 10^{-6} T S_{T}-3,7506 \cdot 10^{-8} S_{T}^{2}$

Em que k é a condutividade térmica em $\mathrm{W} \cdot \mathrm{m}^{-1}{ }^{\circ} \mathrm{C}-1, T$ é a temperatura em ${ }^{\circ} \mathrm{C}$ e $S_{T}$ é o teor de sólidos totais em $\%$.

Os resultados mostraram que os dois modelos testados obtiveram ajustes satisfatórios $\left(R^{2}>0,9914\right)$. No entanto, o modelo de segunda ordem se sobressaiu ao modelo de primeira ordem com um $\mathrm{R}^{2}=0,9958$. Porém, o menor erro relativo foi observado no modelo de primeira ordem $(0,36 \%)$, indicando que a condutividade térmica das soluções de leite/sacarose foi melhor representada pelo modelo de primeira ordem. Pereira et al., 2013 e Gonçalves et al., 2017 também observaram que a condutividade térmica dos produtos lácteos testados aumentou linearmente com o aumento da temperatura e do teor de água.

\section{CONCLUSÃO}

A densidade e a condutividade térmica das soluções de leite/sacarose mostraram dependência da temperatura e do teor de sólidos totais. As mesmas foram descritas satisfatoriamente por ambos os modelos de primeira e segunda ordem, sendo melhor representadas pelo modelo de primeira ordem. Assim, é possível melhorar e controlar processos industriais que utilizam soluções de leite/sacarose.

\section{REFERÊNCIAS}

[1] Azoubel, P. M., Cipriani, D. C., El-Aouar, Â. A., Antonio, G. C., Murr, F. E. X., 2005. Effect of concentration on the physical properties of cashew juice. Journal of Food Engineering, 66(4), 413-417.

[2] Castilhos, M.B.M., Betiol, L.F.L., de Carvalho, G.R., Telis-Romero, J., 2017. Experimental study of physical and rheological properties of grape juice using different temperatures and concentrations. Part I: Cabernet Sauvignon. 
Food Res. Int. 100, 724-730. https://doi.org/10.1016/j.foodres.2017.07.075

[3] Castilhos, M.B.M., Betiol, L.F.L., de Carvalho, G.R., Telis-Romero, J., 2017. Experimental study of physical and rheological properties of grape juice using different temperatures and concentrations. Part I: Cabernet Sauvignon. Food Res. Int. 100, 724-730. https://doi.org/10.1016/j.foodres.2017.07.075

[4] Conab - Companhia Nacional de Abastecimento. Disponível em: https://www.conab.gov.br/infoagro/analises-do-mercado-agropecuario-e-extrativista/analises-do-mercado/historico-mensal-de-leite/item/12485leite-analise-mensal-outubro-2019. Acesso em: 30 de novembro de 2019.

[5] Gonçalves, B. J., Pereira, C. G., Lago, A. M. T., Gonçalves, C. S., Giarola, T. M. O., Abreu, L. R., Resende, J. V., 2017. Thermal conductivity as influenced by the temperature and apparent viscosity of dairy products. Journal of dairy science, 100(5), 3513-3525.

[6] Habtegebriel, H., Edward, D., Wawire, M., Sila, D., Seifu, E., 2018. Effect of operating parameters on the surface and physico-chemical properties of spray-dried camel milk powders. Food and Bioproducts Processing, 112, 137-149.

[7] Lin, S.X.Q., Chen, X.D., Chen, Z.D., Bandopadhayay, P., 2003. Shear rate dependent thermal conductivity measurement of two fruit juice concentrates. J. Food Eng. 57, 217-224. https://doi.org/10.1016/S02608774(02)00300-X

[8] Markoska, T., Huppertz, T., Grewal, M. K., Vasiljevic, T., 2019. FTIR analysis of physiochemical changes in raw skim milk upon concentration. LWT, 102, 64-70.

[9] Minim, L. A., Coimbra, J. S., Minim, V. P., Telis-Romero, J., 2002. Influence of temperature and water and fat contents on the thermophysical properties of milk. Journal of Chemical \& Engineering Data, 47(6), 1488-1491.

[10] Munir, M. T., Zhang, Y., Yu, W., Wilson, D. I., Young, B. R., 2016. Virtual milk for modelling and simulation of dairy processes. Journal of dairy science, 99(5), 3380-3395.

[11] Pereira, C. G., Resende, J. V., Giarola, T. M., 2014. Relationship between the thermal conductivity and rheological behavior of acerola pulp: Effect of concentration and temperature. LWT-Food Science and Technology, 58(2), 446-453.

[12] Perry \& Chilton. Manual de engenharia química. Guanabara Dois, Rio de Janeiro (1986).

[13] Usda - United States Departoneladaent of Agriculture. Disponível em: https://www.usda.gov/. Acesso em: 27 de novembro de 2019.

[14] Venturini, K. S., Sarcinelli, M. F., Silva, L. D., 2007. Características do leite. Boletim Técnico, Universidade Federal do Espírito Santo, Pró-Reitoria de Extensão, Programa Institucional de Extensão, Pie-Ufes, 1007(6).

[15] Zainal, B.S., Abdul Rahman, R., Ariff, A.B., Saari, B.N., Asbi, B.A., 2000. Effects of temperature on the physical properties of pink guava juice at two different concentrations. J. Food Eng. 43, 55-59. https://doi.org/10.1016/S02608774(99)00132-6 


\section{Capítulo 7}

Fluidodinâmica da mistura de bagaço de malte e areia em leito de jorro visando a pirólise de biomassa

\section{Natália Pazin de Almeida}

Beatriz Cristina Silvério

José Luiz Vieira Neto

Felipe Santos Pimentel

Taisa Lira Shimosakai

Kássia Graciele dos Santos

Resumo: A pirólise em leito de jorro é uma tecnologia promissora para geração de energia renovável por meio de biomassa, porém, o emprego desse tipo de material puro prejudica a estabilidade fluidodinâmica do equipamento, dificultando sua utilização como reator de pirólise. 0 objetivo deste trabalho foi realizar uma análise do comportamento fluidodinâmico da mistura de bagaço de malte e areia, avaliando como altura de leito estático e fração mássica de biomassa influenciam na condição de mínimo jorro e crítica, com o intuito de contribuir para a aplicação do leito de jorro como reator de pirólise. Comprovou-se que os leitos com maiores alturas e menores frações de biomassa apresentam um maior peso total de partículas, resultando em maiores valores de queda de pressão e vazão de ar para manter o regime de jorro. 


\section{INTRODUÇÃO}

Em 2017, a agricultura e o agronegócio no Brasil contribuíram com 23,5\% do Produto Interno Bruto (PIB). Segundo a Confederação da Agricultura e Pecuária do Brasil (CNA), esta é a maior participação em 13 anos. Para o agronegócio, que engloba toda a cadeia produtiva, incluindo insumos, agropecuária, indústria e serviços, o crescimento estimado para 2018 é de $0,5 \%$ a $1 \%$. (CNA, 2017).

O beneficiamento e industrialização de alimentos na agroindústria gera grande quantidade de resíduos. Dessa forma, faz-se importante o estudo de projetos que proponham a sustentabilidade do sistema industrial de produção.

Um dos setores mais tradicionais da agroindústria brasileira é o cervejeiro, com cadeia produtiva responsável por $1,6 \%$ do PIB e 14\% da indústria de transformação nacional. (CERVBRASIL, 2016). O cereal mais utilizado neste processo é a cevada e, como consequência, o bagaço de malte de cevada é o principal resíduo da indústria cervejeira. Segundo Cordeiro et al. (2012), o bagaço de malte é uma biomassa resultante do processo de filtração do mosto, constituída de restos de casca e polpa dos grãos, misturados, em suspensão ou dissolvidos no mosto.

O uso de biomassa como fonte de energia vem ganhando crescente atenção nos últimos anos. Atualmente, esta é a principal fonte de energia renovável, com uma contribuição de cerca de $14 \%$ para o consumo global mundial, da mesma ordem que o do carvão, 12\% e do gás natural, 15\% (HUANG, et al., 2011).

As tecnologias que convertem biomassa em biocombustíveis podem ser divididas em três categorias principais: termoquímica, bioquímica e físico-química. As tecnologias termoquímicas podem ser subdivididas em três categorias principais de processos: pirólise, gaseificação e combustão. Durante a pirólise, formam-se produtos com aplicações na geração de energia, devido ao seu alto poder calorífico, como carvão, bio-óleo e biogás.

A pirólise é um processo térmico na ausência ou em quantidade controlada de agentes oxidantes, como ar e oxigênio. Neste processo ocorre a ruptura de ligações carbono-carbono e formação de ligações carbono-oxigênio. Das tecnologias termoquímicas de conversão de biomassa em energia, esta é considerada a mais promissora, pois permite selecionar o produto de interesse, que pode ser líquido, sólido ou gasoso.

A mudança nas condições operacionais do processo dá origem a diferentes tipos de pirólise, tais como: pirólise lenta ou carbonificação, pirólise rápida ou liquefação, pirólise à vácuo, pirólise ablativa e pirólise flash ou gaseificação (SANTOS, 2011).

Dentre as técnicas de pirólise, destaca-se a pirólise rápida, por sua eficiência na obtenção de produtos líquidos, como o bio-óleo. Este método é caracterizado por altas taxas de aquecimento, na qual a partícula de biomassa, ao entrar em contato com o gás, é aquecida até que a pressão de vapor de seus voláteis seja alcançada, de forma a criar um fluxo de voláteis, na direção radial, que vai de encontro à superfície da partícula.

Dentre a gama de equipamentos utilizados no processo de pirólise, destaca-se o leito de jorro, pois seu padrão cíclico de movimentação favorece a fluidodinâmica de partículas grandes, que não fluidizam sozinhas de maneira adequada. Além disso, o contato gás-sólido é eficiente, o que garante elevados coeficientes de transferência de calor e massa e baixa segregação de partículas (BACELOS, 2006).

A biomassa, contudo, apresenta insatisfatória fluidez no interior de leitos de jorro, devido à sua baixa densidade. Dessa forma, com o intuito de garantir estabilidade fluidodinâmica ao equipamento, geralmente adiciona-se um material inerte, que, em alguns casos, tem ainda a função de transferir calor para a biomassa, como a areia, por exemplo.

Segundo Santos (2011), o estudo da fluidodinâmica da mistura de biomassa e inerte no leito de jorro é importante, pois interfere diretamente no rendimento e na composição final dos produtos obtidos por pirólise. Os experimentos de mistura de partículas em leito de jorro auxiliam na compreensão dos mecanismos de segregação do equipamento. A segregação ocorre devido às diferentes velocidades terminais das partículas, que acontece devido à distribuição de tamanho e de densidade do material particulado (SANTOS et al., 2012; SANTOS et al, 2015).

Este trabalho teve como objetivo analisar, do ponto de vista fluidodinâmico, a mistura binária contendo bagaço de malte e areia no leito de jorro cônico, avaliando como a altura do leito estático e a fração mássica de biomassa influenciam na velocidade e queda de pressão de mínimo jorro e queda de pressão máxima. 


\section{MATERIAL E MÉTODOS}

A Figura 1 mostra a configuração experimental utilizada para aquisição dos dados abordados neste trabalho. Foram utilizados bagaço de malte, obtido como resíduo de uma indústria cervejeira da cidade de Uberaba/MG, com diâmetro médio de 2,4 mm e areia comum, lavada e peneirada, com diâmetro médio de 1,29 $\mathrm{mm}$. Os experimentos foram realizados no Laboratório de Eficiência Energética I do PPGEN/UFES e os dados enviados à UFTM para análise, usando a metodologia de Xavier (2016).

Figura1 - Unidade experimental (a) Esquema: 1. Leito de jorro cônico, 2. Termopar, 3. Transdutor de pressão, 4. Sistema de aquecimento, 5. Soprador, 6. Condicionador de sinais, 7. Placa de aquisição de dados, 8. Microcomputador; (b) Geometria do leito de jorro.

(a)

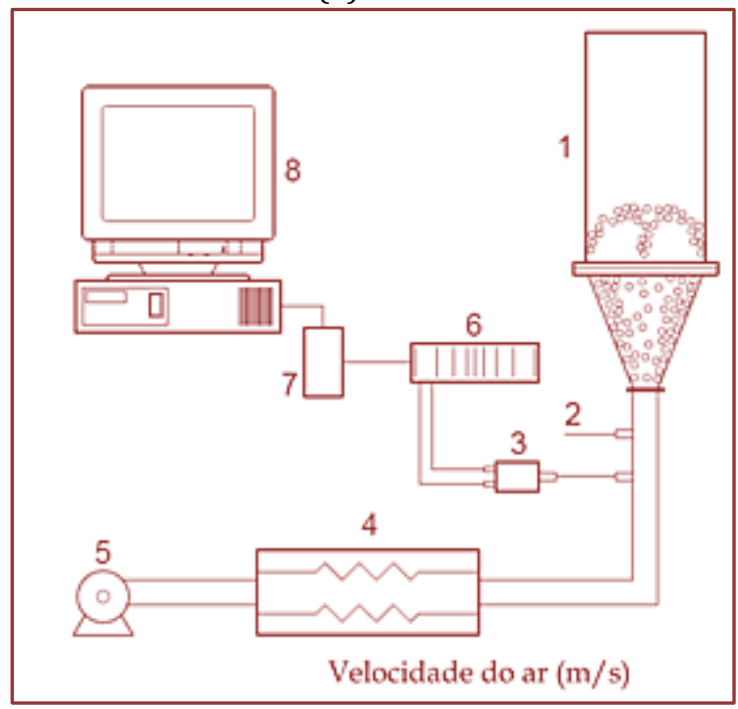

(b)

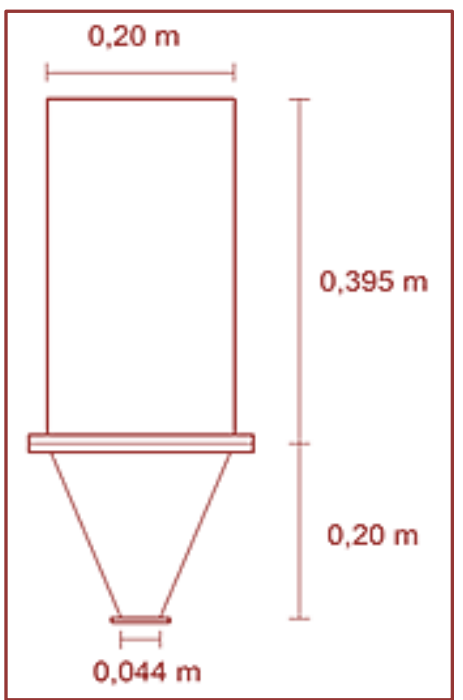

Uma matriz de planejamento de experimentos foi montada a fim de investigar os efeitos da fração mássica das partículas de bagaço de malte $\left(\mathrm{X}_{\mathrm{b}}\right)$ e altura de leito estático $\left(\mathrm{H}_{0}\right)$ na fluidodinâmica do processo. Através dos pares de velocidade superficial do ar e queda de pressão do leito, as curvas características do leito de jorro foram construídas e assim foi possível determinar a velocidade de jorro mínimo $\left(\mathrm{q}_{\mathrm{jm}}\right)$, sua queda de pressão correspondente $\left(-\Delta \mathrm{P}_{\mathrm{jm}}\right)$ e a queda de pressão máxima $\left(-\Delta \mathrm{P}_{\text {máx }}\right)$. Os dados foram analisados através de regressão múltipla. Os parâmetros significativos da regressão foram determinados utilizando a distribuição $t$ de Student, sendo desconsiderados significativos aqueles com nível de significância $(p)$ maior que 10\%. Nas equações 1 e 2 são apresentadas, respectivamente, a codificação da fração mássica das partículas de bagaço de malte e da altura de leito estático. A

Tabela 1 mostra os dados de geometria do leito e propriedades das partículas empregadas neste trabalho.

$$
\begin{aligned}
& \mathrm{x}_{1}=\frac{\mathrm{X}_{\mathrm{b}}-0,3}{0,2} \\
& \mathrm{x}_{2}=\frac{\mathrm{H}_{0}-0,08}{0,02}
\end{aligned}
$$


Tabela 1. Condições de operação e propriedades das partículas utilizadas nos experimentos de leito de jorro

\begin{tabular}{|c|c|c|}
\hline $\mathrm{D}_{\mathrm{c}}[\mathrm{m}]$ & Diâmetro do cilindro & 0,200 \\
\hline $\mathrm{D}_{0}[\mathrm{~m}]$ & Diâmetro de entrada & 0,044 \\
\hline $\mathrm{H}_{\mathrm{c}}[\mathrm{m}]$ & Altura da parte cônica & 0,200 \\
\hline $\mathrm{H}[\mathrm{m}]$ & Altura da parte cilíndrica & 0,395 \\
\hline$\Gamma$ & Ângulo do cone & $45^{\circ}$ \\
\hline$\rho_{\mathrm{b}}\left[\mathrm{kg} / \mathrm{m}^{3}\right]$ & Densidade aparente da biomassa & 1140,47 \\
\hline$\rho_{\mathrm{i}}\left[\mathrm{kg} / \mathrm{m}^{3}\right]$ & Densidade aparente do inerte & 2480 \\
\hline $\mathrm{d}_{\mathrm{b}}[\mathrm{m}]$ & Diâmetro da biomassa & $2,4.10^{-3}$ \\
\hline $\mathrm{d}_{\mathrm{i}}[\mathrm{m}]$ & Diâmetro do inerte & $1,29.10^{-3}$ \\
\hline$\phi_{\mathrm{b}}$ & Esfericidade da biomassa & 0,342 \\
\hline$\phi_{\mathrm{i}}$ & Esfericidade do inerte & 0,800 \\
\hline$\varepsilon_{0} ; \mathrm{X}_{\mathrm{b}}=0,1$ & Porosidade do leito com $10 \%$ de biomassa em massa & 0,525 \\
\hline$\varepsilon_{0} ; \mathrm{X}_{\mathrm{b}}=0,3$ & Porosidade do leito com $30 \%$ de biomassa em massa & 0,648 \\
\hline$\varepsilon_{0} ; \mathrm{X}_{\mathrm{b}}=0,5$ & Porosidade do leito com $50 \%$ de biomassa em massa & 0,721 \\
\hline
\end{tabular}

Fonte: Dos Autores.

\subsection{CORRELAÇõES EMPÍRICAS CÁLCULO DOS PARÂMETROS FLUIDODINÂMICOS}

A literatura possui algumas correlações para prever a velocidade de jorro mínimo $\left(\mathrm{q}_{\mathrm{jm}}\right)$, a partir do número de Reynolds no jorro mínimo $\left(\operatorname{Re}_{j \mathrm{~m}}\right)$, sua queda de pressão correspondente $\left(-\Delta \mathrm{P}_{\mathrm{jm}}\right)$ e a queda de pressão máxima $\left(-\Delta \mathrm{P}_{\text {máx }}\right)$. Estes modelos geralmente compreendem a interferência de fatores geométricos, das propriedades das partículas e das condições iniciais do processo.

Considerando-se que foi estudada uma mistura de partículas de diferentes diâmetros e densidades, para cada correlação foram analisadas três diferentes definições de diâmetro efetivo de partícula e de massa específica efetiva. A definição de Goossens et al. (1971) considera as frações mássicas dos componentes da mistura estudada e suas massas específicas individuais e efetiva total no cálculo do diâmetro efetivo, como mostram as equações 3 e 4 .

$$
\begin{gathered}
\frac{1}{\rho_{\text {eff }}}=\frac{\left(1-X_{b}\right)}{\rho_{i}}+\frac{X_{b}}{\rho_{b}} \\
\frac{1}{d_{\text {eff }} \rho_{\text {eff }}}=\frac{\left(1-X_{b}\right)}{\rho_{i} d_{i}}+\frac{X_{b}}{\rho_{b} d_{b}}
\end{gathered}
$$

A definição de Bai et al. (1996) considera apenas os diâmetros individuais e as frações mássicas dos componentes da mistura no cálculo do diâmetro efetivo, como apresentado nas equações 5 e 6. Asif (2010) considera as frações volumétricas individuais no cálculo do diâmetro efetivo, as esfericidades e diâmetros das partículas, através das equações 7 e 8 . O número de Reynolds no jorro mínimo é dado pela equação 9. Dessa forma, de posse da massa específica $(\rho)$, da viscosidade dinâmica do fluido $(\mu)$ do leito de jorro e do diâmetro efetivo das partículas $\left(\mathrm{d}_{\mathrm{eff}}\right)$, é possível prever a velocidade de jorro mínimo $\left(\mathrm{q}_{\mathrm{jm}}\right)$. O número de Arquimedes $(\operatorname{Ar})$, que aparece em várias dessas correlações, representa o movimento do fluido devido à diferença entre as massas específicas efetiva das partículas e do fluido. Esta expressão retrata a relação existente entre as forças gravitacional e viscosa, como mostra a equação 10.

$$
\rho_{\text {eff }}=\frac{1}{\frac{\left(1-X_{b}\right)}{\rho_{i}}+\frac{X_{b}}{\rho_{b}}}
$$

$$
d_{\text {eff }}=\frac{1}{\frac{\left(1-X_{b}\right)}{d_{i}}+\frac{X_{b}}{d_{b}}}
$$




$$
\rho_{\mathrm{eff}}=\mathrm{X}_{\mathrm{v}, \mathrm{i}} \rho_{\mathrm{i}}+\mathrm{X}_{\mathrm{v}, \mathrm{b}} \rho_{\mathrm{b}}
$$

$$
\frac{1}{d_{\text {eff }}}=\left[\left(\frac{X_{V, i}}{\phi_{i} d_{i}}\right)+\left(\frac{X_{v, b}}{\phi_{b} d_{b}}\right)\right]
$$

$$
(\operatorname{Re})_{j \mathrm{jm}}=\frac{\mathrm{q}_{\mathrm{jm}} \rho \mathrm{d}_{\mathrm{eff}}}{\mu}
$$

$$
\operatorname{Ar}=\frac{\rho d_{\text {eff }}^{3}\left(\rho_{\text {eff }}-\rho\right)}{\mu^{2}}
$$

A tabela 2 resume as equações empíricas da literatura para predição da velocidade de ar e queda de pressão no jorro mínimo e máxima queda de pressão no leito, empregadas neste trabalho (Equações 11 a 23), bem como as condições de contorno de cada correlação.

\section{RESULTADOS E DISCUSSÃO}

A tabela 3 exibe as velocidades de ar $\left(\mathrm{q}_{\mathrm{jm}}[\mathrm{m} / \mathrm{s}]\right)$, e quedas de pressão experimentais $\left(-\Delta \mathrm{P}_{\mathrm{jm}}[\mathrm{Pa}]\right)$ referentes ao jorro mínimo de cada composição de mistura analisada, além das quedas de pressão máximas $\left(-\Delta \mathrm{P}_{\text {máx }}[\mathrm{Pa}]\right) . \mathrm{A}$ condição de jorro mínimo foi identificada por meio do gráfico que relaciona a queda de pressão no leito de jorro e a vazão de alimentação de ar. Analisando os resultados da tabela 3, observa-se que a velocidade e a queda de pressão de jorro mínimo das misturas aumentam à medida que a altura de leito estático aumenta.

Na figura 2 é possível observar a curva característica da queda de pressão em função da velocidade do ar de um leito de jorro operando com mistura binária de bagaço de malte e areia com diferentes $\mathrm{X}_{\mathrm{b}}$, para alturas de leito estático de 6,8 e $10 \mathrm{~cm}$, respectivamente. Em destaque é possível observar os pontos de velocidade de jorro mínimo. É possível concluir que, para uma mesma fração de biomassa na mistura, à medida que se aumenta a altura de leito estático, $\mathrm{q}_{\mathrm{jm}}$ aumenta.

Além disso, misturas com frações mássicas de bagaço de malte entre 10-50\% são adequadas para realizar a pirólise, visto que regimes de jorro estáveis foram alcançados em todas as condições experimentais trabalhadas.

Os parâmetros significativos da regressão foram determinados através de um teste de hipótese utilizando a distribuição $t$ de Student, sendo desconsiderados significativos os parâmetros com nível de significância $(p)$ maior que $10 \%$.

Através da Equação $34\left(r^{2}=0,9641\right)$, que representa a velocidade de ar de jorro mínimo é possível observar que apenas a média e as variáveis na forma isolada apresentaram efeito significativo na resposta. 
Tabela 2. Erros relativos para as correlações empíricas de velocidade de jorro mínimo.

\begin{tabular}{|c|c|c|c|}
\hline Referências & Correlações & & Condições de Contorno \\
\hline $\begin{array}{l}\text { Gorshtein \& Muklenov } \\
\text { (1964) }\end{array}$ & $(\operatorname{Re})_{\mathrm{jm}}=0,174 \mathrm{Ar}^{0,5}\left(\frac{\mathrm{D}_{\mathrm{b}}}{\mathrm{D}_{0}}\right)^{0,85} \operatorname{tg}\left(\frac{\gamma}{2}\right)^{-1,25}$ & (11) & $\begin{array}{c}\mathrm{H}_{0}=3-15 \mathrm{~cm}, \mathrm{H}_{0} / \mathrm{D}_{0}=1,3-8,5 \gamma \\
=12-60^{\circ}, \mathrm{d}_{\mathrm{p}}=0,5-2,5 \mathrm{~mm} \\
\rho=980-2360 \mathrm{~kg} / \mathrm{m}^{3}\end{array}$ \\
\hline $\begin{array}{c}\text { Muklenov \& Gorshtein } \\
\text { (1965) }\end{array}$ & $\begin{array}{c}(\mathrm{Re})_{\mathrm{jm}}=3,32 \mathrm{Ar}^{0,33}\left(\frac{\mathrm{H}_{0}}{\mathrm{D}_{0}}\right) \operatorname{tg}\left(\frac{\gamma}{2}\right)^{0,55} \\
\frac{-\Delta \mathrm{P}_{\mathrm{jm}}}{\mathrm{H}_{0} \rho_{\mathrm{b}} \mathrm{g}}=7,68\left[\operatorname{tg}\left(\frac{\gamma}{2}\right)\right]^{-0,2}(\mathrm{Re})_{\mathrm{jm}}^{-0,2}\left(\frac{\mathrm{H}_{0}}{\mathrm{D}_{0}}\right)^{-0,33}\end{array}$ & $\begin{array}{l}(12) \\
(13)\end{array}$ & $\begin{array}{c}\mathrm{D}_{0}=10,3-12,9 \mathrm{~mm}, \mathrm{H}_{0}=3-15 \\
\mathrm{~cm}, \gamma=12-60^{\circ}, d_{\mathrm{p}}=0,5-2,50 \\
\mathrm{~mm}, \rho=1000-2360 \mathrm{~kg} / \mathrm{m}^{3} \mathrm{e} \\
D_{c}=5 \mathrm{~cm} .\end{array}$ \\
\hline Goltsiker (1967) & $(\mathrm{Re})_{\mathrm{jm}}=0,73 \mathrm{Ar}^{0,14}\left(\frac{\mathrm{H}_{0}}{\mathrm{D}_{0}}\right)^{0,9}\left(\frac{\rho_{\mathrm{eff}}}{\rho}\right)^{0,47}$ & (14) & $\begin{array}{c}\mathrm{D}_{0}=0,41-1,23 \mathrm{~cm}, \mathrm{H}_{0}=5-31 \\
\mathrm{~cm}, \gamma=26-60^{\circ}, \mathrm{d}_{\mathrm{p}}=0,5-2,5 \mathrm{~mm}, \\
\rho=800-1630 \mathrm{~kg} / \mathrm{m}^{3} .\end{array}$ \\
\hline Tsvik et al. (1967) & $(\operatorname{Re})_{j \mathrm{~m}}=0,4 \mathrm{Ar}^{0,52}\left(\frac{\mathrm{H}_{0}}{\mathrm{D}_{0}}\right)^{1,24} \operatorname{tg}\left(\frac{\gamma}{2}\right)^{0,42}$ & (15) & $\begin{array}{c}\mathrm{D}_{0}=2-4 \mathrm{~cm} ; \mathrm{H}_{0}=10-50 \mathrm{~cm} \\
\mathrm{H}_{0} / \mathrm{D}_{0}=1,6-8,7, \gamma=20-50^{\circ} \\
\mathrm{d}_{\mathrm{p}}=1,5 \text { a } 4,0 \mathrm{~mm}, \rho=1650 \mathrm{a} \\
1700 \mathrm{~kg} / \mathrm{m}^{3}\end{array}$ \\
\hline Olazar et al. (1992) & $(\operatorname{Re})_{j \mathrm{~m}}=0,126 \mathrm{Ar}^{0,5}\left(\frac{\mathrm{D}_{\mathrm{b}}}{\mathrm{D}_{0}}\right)^{1,68} \operatorname{tg}\left(\frac{\gamma}{2}\right)^{-0,57}$ & $(16)$ & \multirow[b]{2}{*}{$\begin{array}{c}D_{0}=3-6 \mathrm{~cm}, H_{0}=3,6-6,1 \mathrm{~cm} \\
\gamma=28-45^{\circ}, d_{p}=1-2,5 \mathrm{~mm} \\
\rho s=240-3520 \mathrm{~kg} / \mathrm{m}^{3}\end{array}$} \\
\hline Olazar et al.(1993) & $\begin{array}{l}\frac{-\Delta \mathrm{P}_{\text {máx }}}{\mathrm{H}_{0} \rho_{\text {eff }}\left(1-\varepsilon_{0}\right) \mathrm{g}}=1,2 \operatorname{tg}\left(\frac{\gamma}{2}\right)^{-0,11}(\mathrm{Re})_{\mathrm{jm}}^{-0,06}\left(\frac{\mathrm{H}_{0}}{\mathrm{D}_{0}}\right)^{0,08} \\
\frac{-\Delta \mathrm{P}_{\mathrm{jm}}}{-\Delta \mathrm{P}_{\text {máx }}}=1+0,116\left(\frac{\mathrm{H}_{0}}{\mathrm{D}_{0}}\right)^{0,50} \operatorname{tg}\left(\frac{\gamma}{2}\right)^{-0,8} \mathrm{Ar}^{0,0125}\end{array}$ & $\begin{array}{l}(17) \\
(18)\end{array}$ & \\
\hline $\begin{array}{l}\text { Pallai \& Nemeth } \\
\text { (1969) }\end{array}$ & $\begin{array}{c}-\Delta \mathrm{P}_{\text {máx }}=H_{0}\left(\rho_{\text {eff }}-\rho\right)(1-\varepsilon) g \\
\frac{-\Delta \mathrm{P}_{j \mathrm{~m}}}{-\Delta \mathrm{P}_{\text {máx }}}=0,8-0,01 \frac{\mathrm{D}_{\mathrm{c}}}{\mathrm{D}_{0}}\end{array}$ & $\begin{array}{l}(19) \\
(20)\end{array}$ & $\mathrm{D}_{\mathrm{c}}=10 \mathrm{a} 30 \mathrm{~cm}$. \\
\hline Sampaio (1978) & $-\Delta \mathrm{P}_{\mathrm{jm}}=\frac{2}{3} \rho_{\mathrm{b}} \mathrm{g} \mathrm{H}$ & $(21)$ & $\begin{array}{c}D_{0}=15 \mathrm{~cm} ; H_{0}=3-15 \mathrm{~cm} ; \\
\gamma=60^{\circ}, d_{p}=4-6 \mathrm{~mm} \\
\rho=1100-1190 \mathrm{~kg} / \mathrm{m}^{3}\end{array}$ \\
\hline San Jose et al. (1996) & $\frac{-\Delta \mathrm{P}_{\mathrm{jm}}}{-\Delta \mathrm{P}_{\text {máx }}}=\left[1+0,35\left(\frac{\left|\mathrm{H}_{0}-\mathrm{H}_{\mathrm{c}}\right|}{\mathrm{D}_{\mathrm{c}}}\right)\left(\frac{\mathrm{D}_{\mathrm{c}}}{\mathrm{D}_{0}}\right)^{1,1} \mathrm{Ar} \mathrm{r}^{0,1}\right]^{-1}$ & $(22)$ & $\mathrm{H}_{0}<35 \mathrm{~cm} ; \rho_{\mathrm{p}}=2420 \mathrm{~kg} / \mathrm{m}^{3}$. \\
\hline $\begin{array}{l}\text { Saldarriaga et al } \\
\qquad \text { (2017) }\end{array}$ & $\frac{-\Delta \mathrm{P}_{\text {máx }}}{\mathrm{H}_{0} \rho_{\text {eff }}\left(1-\varepsilon_{0}\right) \mathrm{g}}=1,20 \operatorname{tg}\left(\frac{\gamma}{2}\right)^{-0,11}(\mathrm{Re})_{\mathrm{jm}}{ }^{-0,06}\left(\frac{\mathrm{H}_{0}}{\mathrm{D}_{0}}\right)^{0,3}$ & (23) & $\begin{array}{l}0,83<\mathrm{H}_{0} / \mathrm{D}_{0}<50 \\
0,25<\operatorname{tg}\left(\frac{\gamma}{2}\right)<0,41 \\
50<(\operatorname{Re})_{\mathrm{jm}}<4900\end{array}$ \\
\hline
\end{tabular}

\section{Fonte: Dos Autores.}

Tabela 3 - Resultados dos testes experimentais.

\begin{tabular}{|c|c|c|c|c|c|c|}
\hline \multicolumn{2}{|c|}{$\mathrm{x} 1\left(\mathrm{X}_{\mathrm{b}}\right)$} & \multicolumn{2}{|c|}{$\mathrm{x} 2\left(\mathrm{H}_{0}[\mathrm{~m}]\right)$} & \multicolumn{2}{|r|}{$\begin{array}{l}\text { Experimental } \\
-\Delta \mathrm{P}_{\mathrm{jm}}[\mathrm{Pa}]\end{array}$} & $-\Delta \mathrm{P}_{\text {máx }}[\mathrm{Pa}]$ \\
\hline-1 & $(0,1)$ & -1 & $(0,06)$ & 4,65 & 385,47 & 549,75 \\
\hline-1 & $(0,1)$ & 0 & $(0,08)$ & 5,68 & 500,68 & 1078,83 \\
\hline-1 & $(0,1)$ & +1 & $(0,10)$ & 7,23 & 592,73 & 1587,23 \\
\hline 0 & $(0,3)$ & -1 & $(0,06)$ & 4,13 & 229,40 & 388,65 \\
\hline 0 & $(0,3)$ & 0 & $(0,08)$ & 5,68 & 248,54 & 513,18 \\
\hline 0 & $(0,3)$ & +1 & $(0,10)$ & 7,23 & 278,91 & 555,11 \\
\hline+1 & $(0,5)$ & -1 & $(0,06)$ & 4,18 & 168,33 & 276,86 \\
\hline+1 & $(0,5)$ & 0 & $(0,08)$ & 5,17 & 189,39 & 323,80 \\
\hline+1 & $(0,5)$ & +1 & $(0,10)$ & 6,20 & 209,88 & 557,70 \\
\hline
\end{tabular}


Figura 2 - Curvas características obtidas para diferentes alturas de leito estático com frações mássicas de bagaço de malte de: (a) $\llbracket X \rrbracket \_b=0,1$; (b) $X \_b=0,3$; (c) $X \_b=0,5$.

(a)

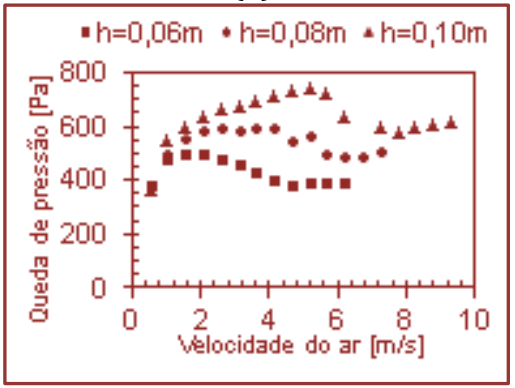

(b)

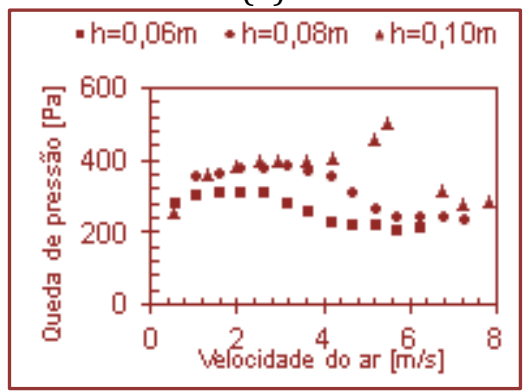

(c)

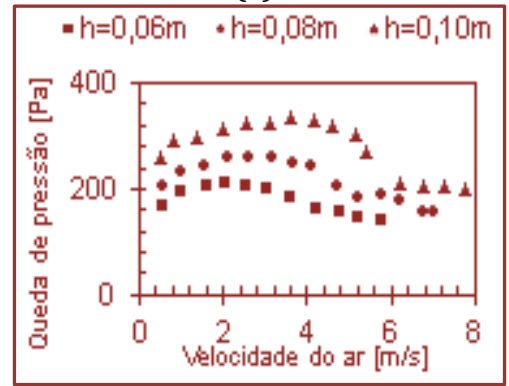

Analisando a Equação 25, O efeito da altura de leito estático influencia de forma direta a velocidade de jorro mínimo, visto que um aumento na altura ocasiona um aumento da massa total da mistura e, consequentemente, da vazão de ar necessária para estabelecer o jorro. Por outro lado, o aumento na fração mássica de bagaço de malte diminui a velocidade de ar necessária para estabelecer o jorro. Isso ocorre, posto que uma maior fração do componente mais leve deixa a densidade da mistura menor, diminuindo a força resistiva e, dessa forma, a velocidade de ar no jorro mínimo.

$$
q_{j m}=5,573-0,336 x_{1}+1,283 x_{2}
$$

A queda de pressão no jorro mínimo pode ser predita pela Equação $25\left(r^{2}=0,9888\right)$ e a queda de pressão máxima, segundo a Equação $26\left(\mathrm{r}^{2}=0,9382\right)$.

$$
\begin{gathered}
-\Delta \mathrm{P}_{\mathrm{jm}}=311,480-151,881 \mathrm{x}_{1}-44,398 \mathrm{x}_{1}^{2}+49,722 \mathrm{x}_{2}-41,428 \mathrm{x}_{1} \mathrm{x}_{2} \\
-\Delta \mathrm{P}_{\text {máx }}=647,901-342,908 \mathrm{x}_{1}-121,691 \mathrm{x}_{1}^{2}+247,464 \mathrm{x}_{2}-189,160 \mathrm{x}_{1} \mathrm{x}_{2}
\end{gathered}
$$

A Figura 3 apresenta as superfícies de resposta obtidas com base nos testes. Das três superfícies, é possível concluir que os maiores valores dessas respostas são observados combinando maiores valores de altura de leito estático e menor fração mássica da biomassa na mistura. Esse fato ocorre porque os leitos com maiores alturas e menores frações de biomassa são mais pesados e têm como resultado maiores valores de queda de pressão durante o regime de jorro. Tais comportamentos foram também observados por Xavier (2016) e Barcelos (2016) ao estudar misturas de biomassas e areia em leitos de jorro cônicos.

Santos et al. (2013) estudaram a dinâmica de uma mistura de areia e bagaço de cana-de-açúcar. Os resultados dos ensaios fluidodinâmicos demonstraram que um leito mais rico em biomassa apresenta um menor peso total de partículas e, consequentemente oferece menor resistência ao fluxo de ar, o que leva a uma queda de pressão mais baixa e a um maior fluxo de ar sob condições mínimas de descarga. 
Figura 3 - Superfície de resposta em função da fração mássica de biomassa e da altura de leito estático, para: (a) velocidade do ar na condição de jorro mínimo; (b) queda de pressão na condição de jorro mínimo; (c) queda de pressão máxima.

(a)

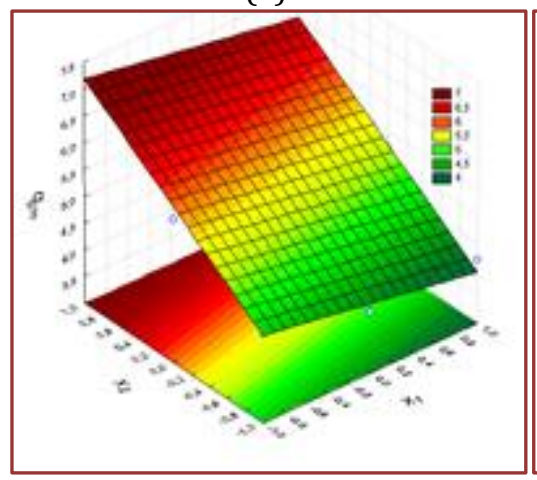

(b)

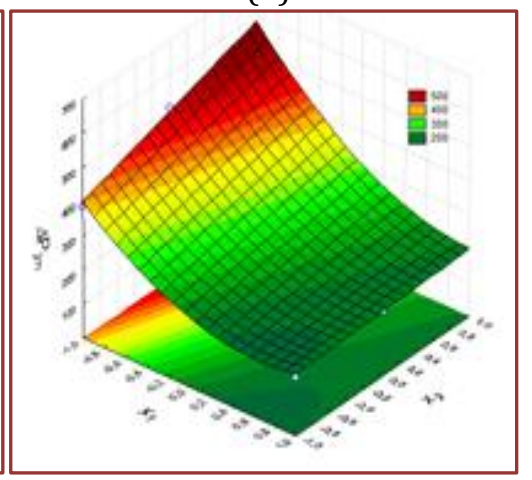

(c)

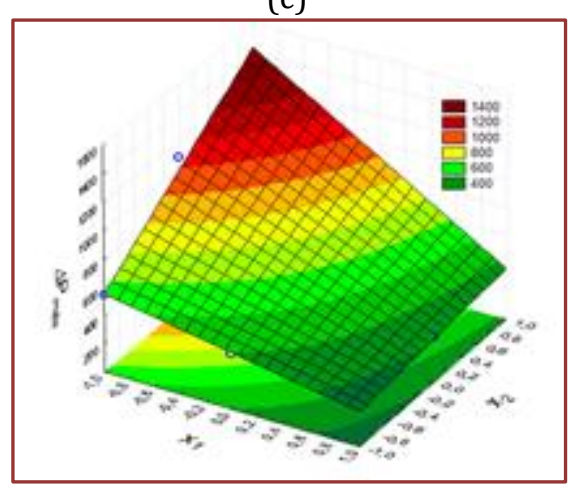

\section{CORRELAÇÕES EMPÍRICAS PARA PREDIÇÃO DE PARÂMETROS FLUIDODINÂMICOS}

As correlações encontradas na literatura para a predição da velocidade mínima de jorro, queda de pressão de jorro mínimo e queda de pressão máxima foram propostas para materiais de textura regular e não contabilizam as características específicas da biomassa. Por esse motivo, para a mistura de partículas tão complexa abordada neste trabalho, algumas correlações, ainda que com faixas de características que englobam as do leito, não apresentaram resultados satisfatórios. A correlação que melhor representou os dados experimentais para $\mathrm{q}_{\mathrm{jm}}$ foi a de Olazar et al.(1992), como mostra a tabela 4.

Tabela 4. Erros relativos para as correlações empíricas de velocidade de jorro mínimo.

\begin{tabular}{|c|c|c|c|}
\hline \multirow{3}{*}{ Correlação } & Propriedade Efetiva & $q_{m j \_}$ & Desvio Relativo (\%) \\
\hline \multirow{3}{*}{ Gorshtein \& Muklenov (1964) } & Asif (2010) & 45,53 \\
\hline & Bai et al.(1996) & & 30,62 \\
\hline & Goossens et al. (1971) & & 27,43 \\
\hline \multirow{3}{*}{ Muklenov \& Gorshtein (1965) } & Asif (2010) & & 51,91 \\
\hline & Bai et al.(1996) & & 52,14 \\
\hline & Goossens et al. (1971) & & 52,19 \\
\hline & Asif (2010) & & 44,95 \\
\hline \multirow{3}{*}{ Goltsiker (1967) } & Bai et al.(1996) & & 58,30 \\
\hline & Goossens et al. (1971) & & 60,33 \\
\hline \multirow{3}{*}{ Tsvik et al. (1967) } & Asif (2010) & & 24,05 \\
\hline & Bai et al.(1996) & & 22,63 \\
\hline & Goossens et al. (1971) & & 21,37 \\
\hline & Asif (2010) & & 4,83 \\
\hline & Bai et al.(1996) & 6,34 \\
\hline
\end{tabular}

Fonte: Dos Autores.

Este modelo é apropriado para leitos moderadamente profundos $\left(\mathrm{H}_{0} / \mathrm{D}_{\mathrm{c}}=1-2\right)$ e requer extrapolação para a previsão de leitos rasos, como é o caso do equipamento analisado neste trabalho $\left(\mathrm{H}_{0} / \mathrm{D}_{\mathrm{c}}<1\right)$. $\mathrm{O}$ cone era mais íngreme em comparação ao ângulo de $60^{\circ}$ do leito experimental, mas ainda assim, é possível observar que faixa de diâmetro de entrada do leito inclui o valor de $4,4 \mathrm{~cm}$, do leito de jorro analisado.

Quando comparada, por exemplo, à correlação de Goltsiker (1967), em que a faixa de ângulo aceita pelo modelo engloba o ângulo do leito de jorro utilizado nos experimentos, observa-se que este parâmetro não é suficiente para garantir um bom ajuste, uma vez que as demais características do leito se desviam de da faixa de validade da equação. 
Assim, o modelo de Goltsiker (1967) foi o que menos ajustou os dados experimentais, mesmo com faixas de diâmetro e massa aparente válidas. Dessa forma, a faixa de validade do diâmetro de entrada do leito mostrou-se o parâmetro mais importante na escolha da correlação para ajuste.

O erro relativo de $4,83 \%$ utilizando as definições de propriedades efetivas de Bai et al.(1996) sugere que o modelo de Olazar et al. (1992) é satisfatório para prever a velocidade de jorro mínimo da mistura de bagaço de malte e areia, quando associado a essa definição.

Olazar et al. (2006) observaram que para partículas finas, com $d_{p}$ entre 0,3 e $0,8 \mathrm{~mm}$, a correlação de diâmetro efetivo proposta por Bai et al. (1996) é satisfatória, enquanto a definição de diâmetro efetivo proposta por Goossens et al. (1971) é recomendada para partículas grossas, com $d_{p}$ entre 0,8 e 4,0 mm. No entanto, para a velocidade de jorro mínimo, a utilização de Bai et al. para cálculo das propriedades efetivas ajustou melhor algumas das correlações estudadas, apesar dos resultados obtidos pela definição de Goossens et al. (1971) também apresentar resultados satisfatórios.

A tabela 5 mostra os resultados preditos de queda de pressão no jorro mínimo obtido pelas correlações, empregando as três diferentes definiçõos de densidade de mistura e diâmetro efetivo.

Tabela 5. Erros relativos para as correlações empíricas de queda de pressão na condição de jorro mínimo.

\begin{tabular}{|c|c|c|c|}
\hline Correlação & Propriedade Efetiva & $-\Delta P_{j m \_p}$ & Desvio Relativo (\%) \\
\hline \multirow{3}{*}{ Muklenov \& Gorshtein (1965) } & Asif (2010) & & 6,92 \\
\hline & Bai et al.(1996) & & 5,45 \\
\hline & Goossens et al. (1971) & & 6,30 \\
\hline \multirow{3}{*}{ Pallai \& Nemeth (1969) } & Asif (2010) & & 51,08 \\
\hline & Bai et al.(1996) & & 51,08 \\
\hline & Goossens et al. (1971) & & 51,08 \\
\hline \multirow{3}{*}{ Sampaio (1978) } & Asif (2010) & & 67,92 \\
\hline & Bai et al.(1996) & & 67,92 \\
\hline & Goossens et al. (1971) & & 67,92 \\
\hline \multirow{3}{*}{ Olazar et al. (1993) } & Asif (2010) & & 33,81 \\
\hline & Bai et al.(1996) & & 33,55 \\
\hline & Goossens et al. (1971) & & 33,50 \\
\hline \multirow{3}{*}{ San José et al. (1996) } & Asif (2010) & & 51,79 \\
\hline & Bai et al.(1996) & & 56,88 \\
\hline & Goossens et al. (1971) & & 57,77 \\
\hline
\end{tabular}

Fonte: Dos Autores.

A correlação de Mukhlenov e Gorshtein (1965) para $-\Delta \mathrm{P}_{\mathrm{jm}}$, apresentou o resultado mais aproximado do experimental, com erro relativo de 5,45\%. Essa equação leva em conta o efeito da densidade bulk, e é válida para cones de $60^{\circ}$, como o empregado neste trabalho. O fato de ter sido desenvolvida para um leito de apenas $5 \mathrm{~cm}$, aponta que o diâmetro do leito apresenta pequena influência na resposta da queda de pressão no jorro mínimo.

Já a correlação de Sampaio (1978) apresentou o pior ajuste para a predição da queda de pressão de jorro mínimo, como pode ser observado pelos valores do desvio relativo, na tabela 5, o que pode ser explicado pela faixa de diâmetro de partícula de para esta correlação, cerca de duas vezes e meia maior que a faixa utilizada os testes.

Quanto à predição da máxima queda de pressão no leito, tabela 6 indica que a correlação que melhor representou os dados experimentais para $-\Delta \mathrm{P}_{\text {máx }}$ foi a de Pallai \& Nemeth (1969), com erro relativo de 13,91\%. Este modelo que considera válida uma faixa de Reynolds para condição de jorro mínimo entre 50 e 4900, abrangendo, assim, a faixa de valores experimentais, de 234 a 765. Além disso, a relação entre altura de leito estático e diâmetro de entrada do leito foi respeitada. 
Tabela 6. Erros relativos para as correlações empíricas de queda de pressão máxima.

\begin{tabular}{|c|c|c|c|}
\hline Correlação & Propriedade Efetiva & $-\Delta \mathrm{P}_{\max \_\mathrm{p}}$ & Desvio Relativo (\%) \\
\hline \multirow{3}{*}{ Olazar et al. (1993) } & Asif (2010) & & 14,91 \\
\hline & Bai et al.(1996) & & 16,20 \\
\hline & Goossens et al. (1971) & & 16,46 \\
\hline \multirow{3}{*}{ Saldarriaga et al. (2017) } & Asif (2010) & & 14,09 \\
\hline & Bai et al.(1996) & & 14,02 \\
\hline & Goossens et al. (1971) & & 14,00 \\
\hline \multirow{3}{*}{ Pallai \& Nemeth (1969) } & Asif (2010) & & 13,91 \\
\hline & Bai et al.(1996) & & 13,91 \\
\hline & Goossens et al. (1971) & & 13,91 \\
\hline
\end{tabular}

Fonte: Dos Autores.

É possível notar através das tabelas de 4 a 6 , que a definição das propriedades efetivas afeta de maneira significativa apenas a predição da velocidade de jorro mínimo, mas não apresenta efeito considerável na previsão de valores de queda de pressão de jorro mínimo e queda de pressão máxima. Este fato já era esperado, pois o número de Arquimedes possui expoentes mais significativos nessas correlações, exercendo, dessa forma, maior influência no cálculo de $\mathrm{q}_{\mathrm{jm}}$. É importante salientar que o número de Arquimedes é o parâmetro que mais sofre influência ao se variar a correlação para definir as propriedades efetivas, já que o diâmetro efetivo aparece elevado ao cubo em seu cálculo.

\section{CONCLUSÕES}

A partir dos resultados obtidos para fluidodinâmica das misturas de areia e bagaço de malte em leito de jorro, conclui-se que misturas com frações mássicas de biomassa entre 10-50\% são adequadas para proceder testes de pirólise, pois regimes de jorro estáveis foram alcançados em todas as condições experimentais trabalhadas. Entretanto, é necessário analisar, do ponto de vista térmico, se a quantidade de areia nas misturas é suficiente para que a biomassa seja aquecida homogeneamente e, assim, aumentar a eficiência de conversão no reator.

A condição de jorro mínimo variou significativamente com a mudança nas condições experimentais estudadas. A velocidade de jorro mínimo e a queda de pressão aumentam conforme a altura do leito estático aumenta e conforme a fração mássica do bagaço de malte diminui. Portanto, os leitos com maiores alturas e menores frações de biomassa apresentam um maior peso total de partículas, resultando em maiores valores de queda de pressão e vazão de ar para manter o regime de jorro.

Para a mistura de bagaço de malte e areia, não foi encontrada na literatura nenhuma correlação para prever satisfatoriamente a pressão de jorro mínimo. A correlação de Olazar et al. (1992) apresentou bons resultados para a velocidade de jorro mínimo, com erro relativo de $4,83 \%$ utilizando as definições de propriedades efetivas de Bai et al.(1996). A correlação que melhor representou os dados experimentais para $-\Delta \mathrm{P}_{\text {máx }}$ foi a de Pallai \& Nemeth (1969) com erro relativo de 13,91\% para as três definições de propriedades efetivas analisadas. Para $-\Delta \mathrm{P}_{\mathrm{jm}}$ a correlação de Mukhlenov e Gorshtein (1965) apresentou o resultado mais aproximado do experimental, com erro relativo de $5,45 \%$.

A definição das propriedades efetivas afeta de maneira significativa apenas a predição da velocidade de jorro mínimo, mas não apresenta efeito considerável na previsão de valores de queda de pressão de jorro mínimo e queda de pressão máxima.

\section{AGRADECIMENTOS}

Os autores agradecem o apoio financeiro da Fapemig (PPM-00564-16), CNPq (Projetos Universal 460513/20141 e 445855/2014-2). Ao PPGMQMG, Rede Mineira de Química e ao PMPIT da UFTM. 


\section{REFERÊNCIAS}

[1] ASIF, M. Minimum fluidization velocities of binary-solid mixtures: Model comparison. World Academy of Science, Engineering and Technology, v. 4, p. 158-162, 2010.

[2] Bacelos, M. S. Análise do comportamento da fluidodinâmica do leito de jorro com misturas de tamanho de partículas. Tese (Doutorado em Engenharia Química) - Programa de Pós-Graduação em Engenharia Química, Universidade Federal de São Carlos, São Carlos, 2006.

[3] Bai, D.; Masuda, Y.; Nakagawa, N.; KATO, K. Hydrodynamic behavior of a binary solids fluidized bed. Journal of Chemical Engineering of Japan, v. 29, p. 211-216, 1996.

[4] Barcelos, K. M. Análise do potencial do leito de jorro como reator para pirólise da casca de coco: estudo experimental e simulação via CFD. 2016. Dissertação (Mestrado em Energia) - Programa De Pós-Graduação Em Energia, Universidade Federal do Espírito Santo, 2016.

[5] Cervbrasil - Associação Brasileira da Indústria de Cerveja, anuário 2016.

[6] CNA, Confederação da Agricultura e Pecuária do Brasil. Agronegócio contribui para queda da inflação e geração de empregos em 2017. Central de Comunicação. Disponível em: <http://www.cnabrasil.org.br/noticias/agronegocio-contribui-para-queda-da-inflacao-e-geracao-de-empregos-em2017>. Acesso em 23 dez. 2017.

[7] Cordeiro, L. G.; El-Aouar, A. A.; Gusmão, R. P. Caracterização do Bagaço de Malte Oriundo de Cervejarias. Revista Verde (Mossoró - RN) 20-22 p, 2012.

[8] Gorshtein, A. E.; Mukhlenov, L. P. Hydraulic resistance of a fluidized bed in a cyclone without a grate: Critical gas rate corresponding to the beginning of jet formation. Zhurnal Khimicheskaya Promyshlennost, 1964

[9] Huang, Y. F., Kuan, W. H.; Chiueh, P. T., LO, S. L. A sequential method to analyze the kinetics of biomass pyrolysis. Bioresource Technology, 2011.

[10] Mukhlenov, I. P., Gorshetein, A. E. Investigation of a spouting bed. Zhurnal Khimicheskaya Promyshlennost, 41, 443-446, 1965.

[11] Olazar, M., Aguado, R., San José, M. J., Alvarez, S., Bilbao, J., Minimum spouting velocity for the pyrolysis of scrap tyres with sand in conical spouted beds, Powder Technology, v. 165, p. 128-132, 2006.

[12] Olazar, M.; San Jose, M. J.; Aguayo, A. T.; Arandes, J. M.; Bilbao, J. Pressure drop in conical spouted beds. The Chemical Engineering Journal, v. 51, p. 53-60, 1993.

[13] Olazar, M.; San Jose, M. J.; Aguayo, A. T.; Arandes, J. M; Bilbao, J. Stable Operation Conditions for Gas-Solid Contact Regimes in Conical Spouted Beds. Industrial \& Engineering Chemistry Research, v. 30, p. 1784-1792, 1992.

[14] Pallai, I.; Nemeth, J.. Analysis of flow forms in a spouted bed apparatus by the so-called phase diagram. In: International Congress of Chemical Engineer (CHISA), 3, Praga, 1969.

[15] Saldarriaga, J. F.; Atxutegi, A.; Aguado, R. Altzibar, H.; Bilbao, J.; OLAZAR, M. Correlations for calculating peak and spouting pressure drops in conical spouted beds of biomass. Journal of the Taiwan Institute of Chemical Engineers, v. 80, p. 678-685, 2017.

[16] Santos, K. G. Aspectos fundamentais da pirólise de biomassa em leito de jorro: fluidodinâmica e cinética do processo. 2011. Tese (Doutorado em Engenharia Química) - Programa de Pós-Graduação em Engenharia Química, Universidade Federal de Uberlândia, Uberlândia, 2011.

[17] Santos, K. G.; Campos, A. V. P.; Ferreira, L. V.; Santana, R. C.; Barrozo, M. A. S. Fluid Dynamics of a SandBiomass Mixture in a Spouted-Bed Reactor for Fast Pyrolysis. Chemical Engineering \& Technology, 36, 2148-2154, 2013.

[18] Santos, K.G.; Francisquetti, M.C.C.; Malagoni, R.A.; Barrozo, M. A. S. Fluid Dynamic Behavior in a Spouted Bed with Binary Mixtures Differing in Size. Drying Technology, v. 33, 14, 2015.

[19] Santos, K. G.; Santos, D. A.; Duarte, C. R.; Murata, V. V.; Barrozo, M. A. S.. Spouting of Bidisperse Mixture of Particles: A CFD and Experimental Study. Drying Technology, v. 30, p. 1354-1367, 2012.

[20] Tsvik, M.Z.; Nabiev, M.N.; Rizaev, N.U.; Merenkov, K.V.; Vyzgo, V.S. The velocity for external spouting in the combined process for production of granulated fertilizers. Uzbekskii Khimichesk, v. 11, p. 50-69, 1967.

[21] Xavier, T. P. Contribuições para a pirólise da casca de macadâmia em leito de jorro cônico. Tese (Doutorado em Engenharia Química) - Programa de Pós-Graduação em Engenharia Química, Universidade Federal de Uberlândia, Uberlândia, 2016. 


\section{Capítulo 8}

\section{Avaliação da acumulação de metais em plantas medicinais da Vila do Elesbão / Santana - AP}

\section{Hina da Silva Furtado \\ Alexandro Cezar Florentino \\ Irlon Ferreira Maciel \\ Josivan da Silva Costa \\ Roberto Messias Bezerra}

Resumo: 0 uso de plantas medicinais pela população é uma cultura milenar atribuída para tratar diversas enfermidades, porém, o uso destes vegetais deve ser realizado com cautela, pois, estas espécies vegetais podem abrigar concentrações séricas de metais pesados, que podem acumular no organismo e causar intoxicações. A presente pesquisa teve como objetivo investigar a bioacumulação de metais em plantas medicinais e solo, oriundos da Vila do Elesbão em Santana-AP, determinando assim a concentração dos metais $\mathrm{Fe}, \mathrm{Cr}, \mathrm{Cu}, \mathrm{Ni}, \mathrm{Ca}, \mathrm{Mg}, \mathrm{Pb}, \mathrm{Mn}, \mathrm{Cd}$ e Co. Deste modo, o estudo buscou investigar a relação entre os metais existentes em solo e os absorvidos pela planta. Para determinação dos metais utilizou-se a técnica de espectrometria de absorção atômica. A significância estatística foi calculada usando o teste ANOVA com intervalo de confiança de $95 \%$. A pesquisa constatou a existência de metais em amostras de solo e planta, e por meio de um estudo estatístico foi possível estabelecer a existência da relação entre os metais presentes em solo e sua disponibilidade em plantas medicinais. 


\section{INTRODUÇÃO}

0 uso de plantas medicinais para o tratamento de doenças é uma prática humana muito antiga. Atualmente, esse costume ainda é a única alternativa de algumas comunidades. A utilização de plantas como fitoterápicos deve ser avaliado com cautela, pois algumas plantas podem vir a apresentar certo grau de toxicidade para o organismo humano, como por exemplo, a presença de elevadas concentrações de metais pesados, Veiga e Freire (2005).

Plantas que acumulam mais de $100 \mathrm{mg}$ de Cd kg-1 (0,01\%) ou mais do que $500 \mathrm{mg} \mathrm{kg}-1 \mathrm{de} \mathrm{Cr}(0,05 \%)$ no tecido da folha seca podem ser consideradas hiperacumuladoras, Sarma (2011). A característica que as plantas apresentam de serem bioacumuladoras de metais pesados as torna um perigo para a saúde, pois ao serem ingeridas transferem o metal acumulado em suas folhas, caule e raízes, para o organismo humano. A intoxicação por metais afeta, por exemplo, os sistemas gastrointestinais, neurológico e imunológico. Os metais mais perigosos são Cádmio, Chumbo e Mercúrio, pois ainda não se encontrou uma função biológica para estes, Chojnacka (2010).

As plantas retiram do ambiente os componentes necessários para as reações metabólicas essenciais para a manutenção de suas células e seu crescimento, tais como, os metais. Dentre estes metais, temos alguns essenciais, como o $\mathrm{Mg}$, Ca e $\mathrm{K}$, outros essenciais em pequenas quantidades como $\mathrm{Fe}$, $\mathrm{Zn}$ e $\mathrm{Cu}$, e outros não essenciais como $\mathrm{Pb}, \mathrm{Cr}$ e Ni, Faquin (2005).

Os metais absorvidos sofrem um transporte radial pela raiz, encontrando um primeiro filtro de difusão e de regulação na endoderme. Já no estelo, os metais seguem essencialmente via xilema e, em suas relações com as células vizinhas, podem induzir alterações na diferenciação do próprio sistema vascular, uma vez que, em concentrações menores, alcançam as folhas, podendo alterar a estrutura e o funcionalidade das células fotossintéticas, Kirkby e Romheld (2007).

Podem-se destacar dois tipos de mecanismos de absorção de metais que explicam a dinâmica destes nos vegetais: a absorção passiva na qual o metal entra de um meio mais concentrado, solução externa, para outro de maior concentração, a qual corresponde à parede celular, isto ocorre por difusão e trocas iônicas, os espaços reservados a estes metais são preferencialmente para trocas de íons bivalentes, a outra forma é a ativa na qual há a ocupação do simplasto radicular que faz com que metal atravesse a barreira lipídica da plasmalema, atingindo o citoplasma, desta forma o elemento chega ao vacúolo depois de vencer a outra barreira representada pelo tonoplasto. 0 mecanismo ativo é lento e irreversível, o metal só deixa o citoplasma ou o vacúolo se as membranas forem danificadas. Contudo, a membrana é a responsável pela seleção da absorção de cátions e ânions, Faquin (2005).

Estas plantas que apresentam características bioacumuladoras podem ser excelentes bioindicadoras de contaminação ambiental, pois absorvem com facilidade alguns elementos poluentes. No entanto, o emprego destas como bioindicadoras não substitui análises convencionais, mas, é uma opção viável, Klumpp (2001).

\section{MÉTODOS}

\subsection{LOCALIZAÇÃO DA ÁREA DE COLETA}

O estudo foi realizado na Vila do Elesbão, localizada no Município de Santana, no Estado do Amapá, figura1. A Vila do Elesbão está distante aproximadamente $22 \mathrm{~km}$ do centro da Capital do estado do Amapá, é banhada pelo Rio Amazonas, o acesso à comunidade é pelo ramal do Elesbão, e a região abriga uma população de maioria ribeirinha: conforme mostra a Figura 1.

Figura 1a - Mapa da localização do Estado do Amapá, 1b - Mapa da localização do Município de Santana, 1c - Município de Santana e Vila do Elesbão. 
Figura $1 \mathrm{a}$

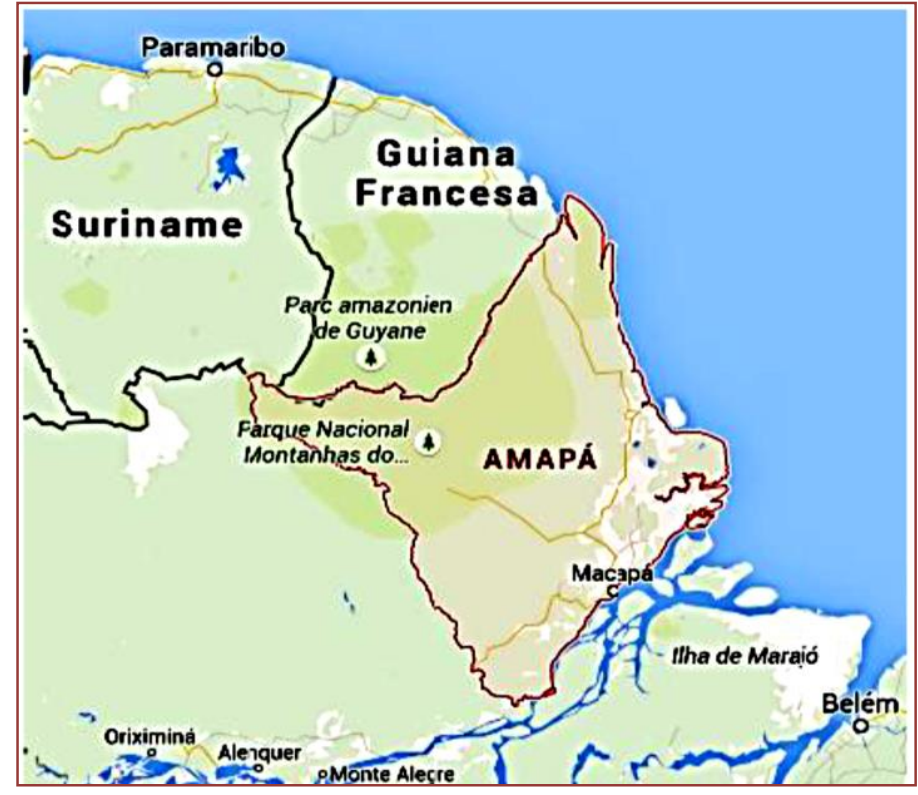

Figura $1 \mathrm{~b}$

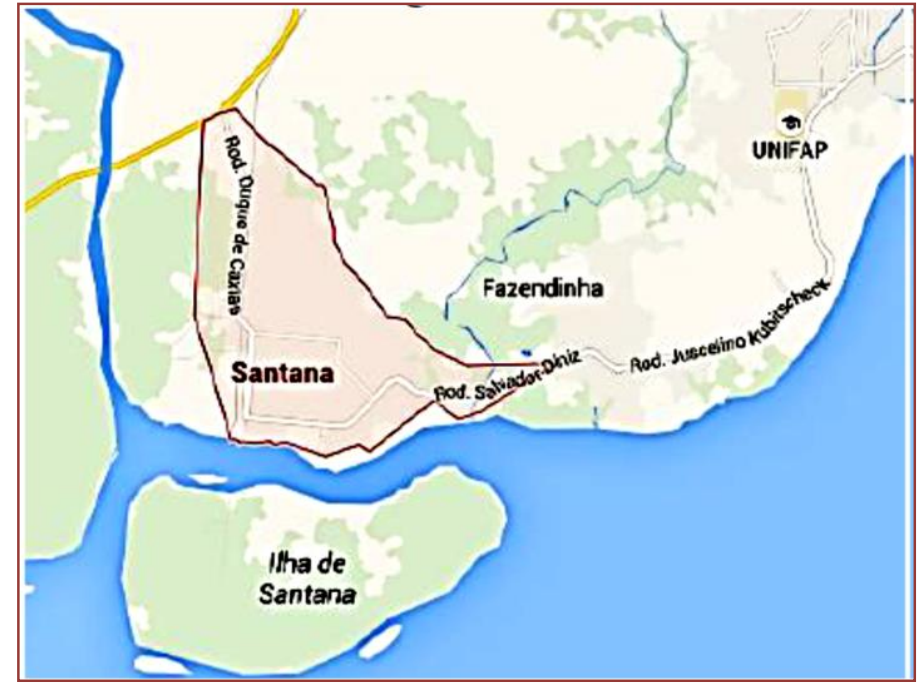

Figura 1c

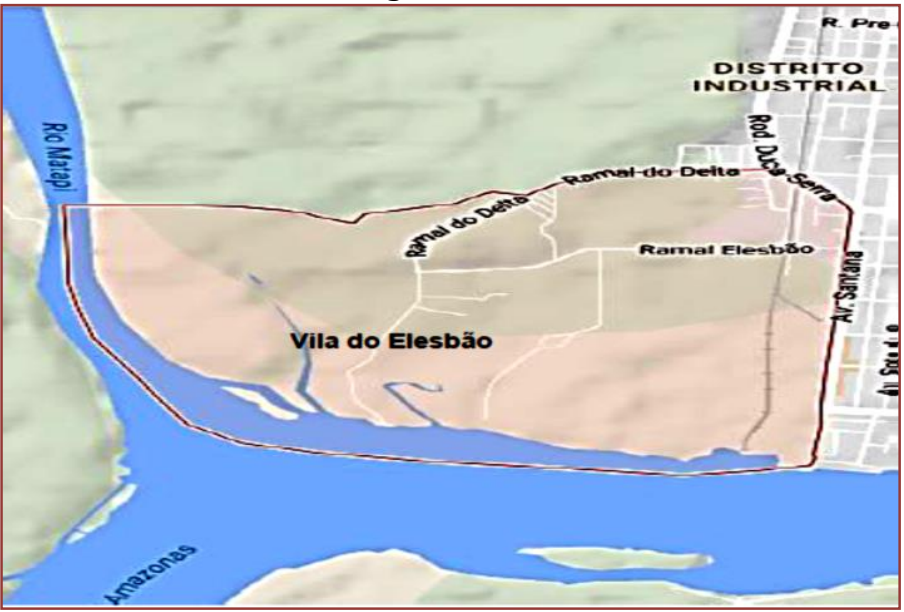

FONTE: Google, 2017. 
As amostras secas das folhas foram separadas e retiradas $0,250 \mathrm{~g}$ de cada espécie vegetal, figura 2 , e $1 \mathrm{~g}$ de cada amostra de solo coletado. Posteriormente iniciou-se o processo de extração de metais por solução de água régia, a solução ácida foi colocada em contato com as amostras durante 1 hora, a temperatura de $100^{\circ} \mathrm{C}$ até a digestão completa. As soluções resultantes do processo foram resfriadas a temperatura ambiente e filtradas para um balão volumétrico de $100 \mathrm{~mL}$.

Figura 2 a, b - Espécies coletadas na Vila do Elesbão.

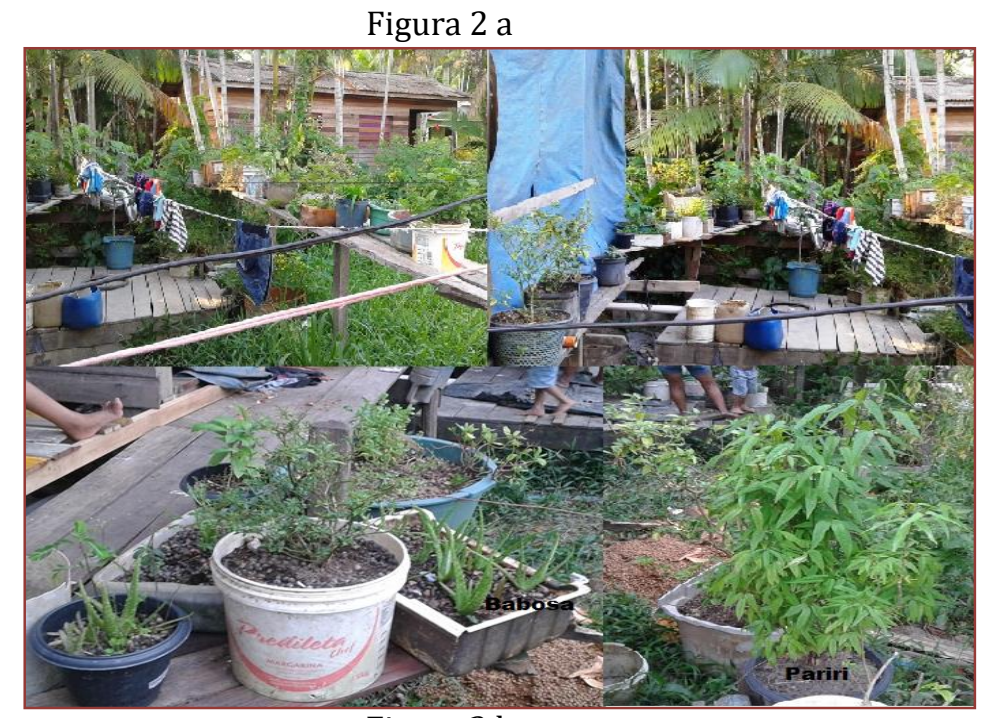

Figura $2 \mathrm{~b}$

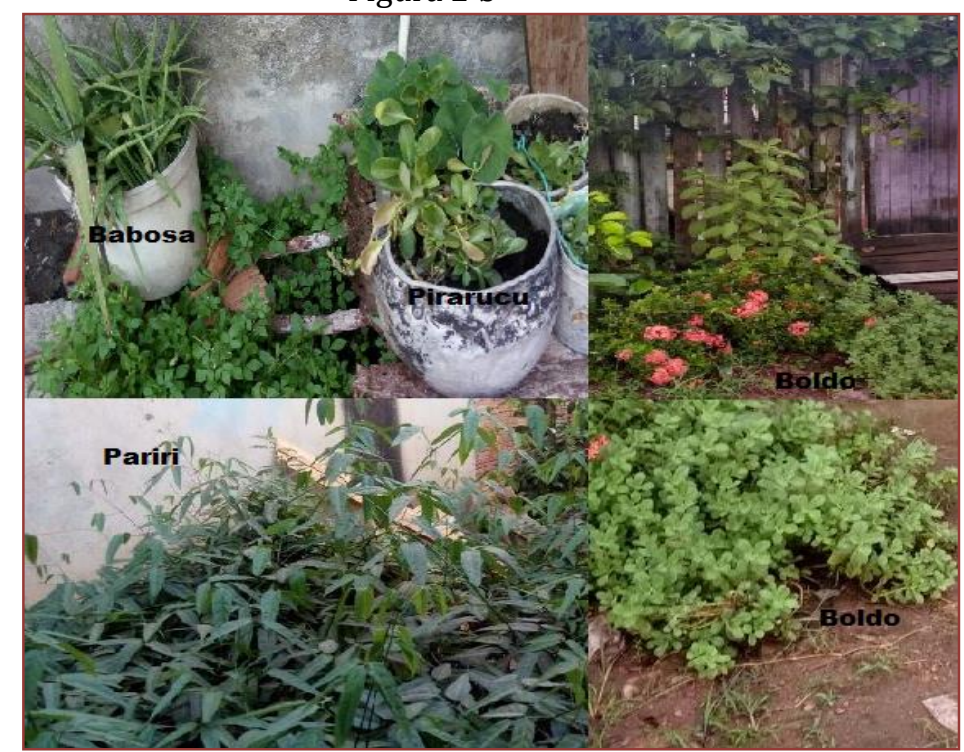

FONTE: Autor, 2017.

\subsection{ANÁLISE ESTATÍSTICA}

Foi utilizado um teste ANOVA One-Way para averiguar se há diferença entre as concentrações de metais nas amostras de solo, e o mesmo teste foi realizado entre as amostras de plantas coletadas, seguido de um teste de Tukey para as amostras que apresentaram diferenças significativas. Foi utilizado um teste de correlação para verificar se há relação entre os teores de metais encontrados no solo com aqueles encontrados nas plantas. As diferenças serão consideradas significantes quando o valor obtido para $p$ for menor que $0,05(p<0,05)$. Os testes estatísticos foram realizados no programa Statistica 7.0 , Oliveira e Ferreira (2010). 


\section{RESULTADOS}

\subsection{DETERMINAÇÃO DE METAIS EM PLANTAS MEDICINAIS E SOLO DA VILA DO ELESBÃO}

As médias e o desvio padrão das concentrações de metais encontrados, por meio de análises de espectrometria de absorção atômica, realizadas em amostras de solo e plantas medicinais da Vila do Elesbão podem ser observadas na Tabela 1 e 2.

Tabela 1- Concentrações dos metais, em mg/g, encontradas nas amostras de Solos coletados na Vila do Elesbão em Santana-AP.

\begin{tabular}{c|c|c|c|c|c|c|c|c|}
\multicolumn{2}{c}{ Amostras } & $\mathrm{Cr}$ & $\mathrm{Cu}$ & $\mathrm{Ni}$ & $\mathrm{Ca}$ & $\mathrm{Mn}$ & $\mathrm{Pb}$ & $\mathrm{Mg}$ \\
\hline Sopl1 & $9.8 \pm 0.57$ & $0.10 \pm 0.00$ & $\mathbf{0 . 3 9} \pm \mathbf{0 . 0 0 2}$ & $0.11 \pm 0.00$ & $0.54 \pm 0.01$ & $6.07 \pm 0.02$ & $\mathbf{0 . 7 7} \pm \mathbf{0 . 0 0 4}$ & $0.53 \pm 0.001$ \\
\hline Sopl2 & $9.9 \pm 0.42$ & $0.12 \pm 0.00$ & $0.31 \pm 0.008$ & $0.10 \pm 0.001$ & $0.46 \pm 0.00$ & $9.7 \pm 0.47$ & $0.64 \pm 0.002$ & $0.54 \pm 0.002$ \\
\hline Sopl3 & $9.8 \pm 0.57$ & $0.10 \pm 0.00$ & $\mathbf{0 . 3 9 \pm 0 . 0 0 2}$ & $0.11 \pm 0.00$ & $0.55 \pm 0.03$ & $6.09 \pm 0.01$ & $0.64 \pm 0.00$ & $0.53 \pm 0.002$ \\
\hline Sopl4 & $9.9 \pm 0.42$ & $0.11 \pm 0.00$ & $0.32 \pm 0.005$ & $0.10 \pm 0.001$ & $0.47 \pm 0.02$ & $9.6 \pm 0.47$ & $\mathbf{0 . 7 7} \pm \mathbf{0 . 0 0}$ & $0.54 \pm 0.002$ \\
\hline \multicolumn{7}{c|}{ DP - Desvio Padrão/ Sopl - Solo planta 1, 2, 3 e 4.}
\end{tabular}

Tabela 2- Concentrações dos metais, em mg/L, encontradas nas amostras de Plantas coletadas na Vila do Elesbão em Santana-AP.

\begin{tabular}{|c|c|c|c|c|c|c|c|c|}
\hline \multirow[t]{2}{*}{ Plantas } & \multicolumn{8}{|c|}{ Médias $\pm \mathrm{DP}$} \\
\hline & $\mathrm{Fe}$ & $\mathrm{Cr}$ & $\mathrm{Cu}$ & $\mathrm{Ni}$ & $\mathrm{Ca}$ & $\mathrm{Mn}$ & $\mathrm{Pb}$ & Mg \\
\hline $\begin{array}{l}\text { Bryophyllum } \\
\text { pinnatum }\end{array}$ & $0.91 \pm 0.018$ & ND & $0.05 \pm 0.00$ & ND & $15.9 \pm 0.03$ & $0.33 \pm 0.003$ & $0.25 \pm 0.007$ & $0.53 \pm 0.001$ \\
\hline $\begin{array}{l}\text { Arrabidaea } \\
\text { chica }\end{array}$ & $1.33 \pm 0.21$ & ND & $0.05 \pm 0.00$ & ND & $8.91 \pm 0.10$ & $0.12 \pm 0.007$ & $0.22 \pm 0.007$ & $0.52 \pm 0.003$ \\
\hline Aloe vera & $0.85 \pm 0.00$ & ND & $0.04 \pm 0.001$ & ND & $10.1 \pm 0.18$ & $4.83 \pm 0.004$ & $0.25 \pm 0.003$ & $0.53 \pm 0.004$ \\
\hline $\begin{array}{l}\text { Plectranthaus } \\
\text { ornatos Codd }\end{array}$ & $0.45 \pm 0.03$ & ND & $0.06 \pm 0.001$ & ND & $16.6 \pm 0.06$ & $1.07 \pm 0.01$ & $0.26 \pm 0.00$ & $0.54 \pm 0.002$ \\
\hline
\end{tabular}

DP - Desvio Padrão.

O teste estatístico (ANOVA) demonstrou que existem diferenças significativas entre as médias das concentrações de metais nas amostras de solo coletadas da Vila do Elesbão. As médias averiguadas possuem nível de significância $\mathrm{p}<0.05$ e o teste Tukey apontou as amostras que apresentaram diferenças significativas.

\subsection{CORRELAÇÃO ENTRE METAIS EXISTENTES NO SOLO E ESPÉCIES VEGETAIS DA VILA DO ELESBÃO.}

A correlação realizada com as concentrações dos metais $\mathrm{Fe}, \mathrm{Cu}, \mathrm{Ca}, \mathrm{Mn}, \mathrm{Pb}$ e $\mathrm{Mg}$ encontrados nas amostras de plantas e de seus respectivos solos, avaliados nesta pesquisa, pode ser observada na Tabela 3. Apenas o metal Cr não foi relacionado nesta análise, pois, não houve detecção deste metal nas amostras de plantas, somente foi constatada sua presença no solo.

Tabela 3- Valores do coeficiente de correlação entre a concentração de metais em plantas e solo.

\begin{tabular}{|c|c|}
\hline Metal & $\begin{array}{c}\text { Planta/Solo } \\
\text { Valor de } \mathrm{r}\end{array}$ \\
\hline $\mathrm{Fe}$ & -0.0905 \\
\hline $\mathrm{Cu}$ & -0.3615 \\
\hline $\mathrm{Ca}$ & 0.04257 \\
\hline $\mathrm{Mn}$ & -0.5140 \\
\hline $\mathrm{Pb}$ & 0.52366 \\
\hline $\mathrm{Mg}$ & 0.19105 \\
\hline \multicolumn{2}{|c|}{$\mathrm{r}-$ Coeficiente de correlação. } \\
\hline
\end{tabular}

Nas análises de correlação realizadas pode-se constata que há relação entre os metais $\mathrm{Ca}, \mathrm{Mg}$ e $\mathrm{Pb}$ presentes no solo com aqueles encontrados nas plantas, ressaltando que o metal que apresenta maior relação é o $\mathrm{Pb}$, com o valor de coeficiente de correlação de 0.52 , ou seja, há um grau relevante de relação 
entre os níveis de concentração deste metal no solo com os níveis das concentrações encontradas nas plantas.

\section{DISCUSSÃO}

Os níveis de metais $\mathrm{Pb}, \mathrm{Cu}, \mathrm{Cr}$ e $\mathrm{Ni}$ encontrados em solos da região da Vila do Elesbão estão dentro dos limites permitidos pela resolução do CONAMA no 420 de Dezembro de 2009 que regulariza os limites de metais pesados em solos residenciais e agrícolas. Porém, a resolução não regulariza os níveis de Fe e $\mathrm{Mn}$, mas, segundo os autores Backer e Brooks, 1989), os níveis considerados normais de $\mathrm{Ni}, \mathrm{Cr}, \mathrm{Cu}, \mathrm{Pb}$ e $\mathrm{Mn}$ em solo são, respectivamente, $40 \mathrm{mg} / \mathrm{g}, 60 \mathrm{mg} / \mathrm{g}, 20 \mathrm{mg} / \mathrm{g}, 10 \mathrm{mg} / \mathrm{g}, 850 \mathrm{mg} / \mathrm{g}$, contudo todas as amostras estão de acordo com os níveis de metais recomendados.

De acordo com Nazir et al. (2015), altas concentrações de metais podem ser tóxico para as plantas e prejudiciais para outros organismos vivos que fazem uso destas, ainda, segundo a WHO para o consumo humano de plantas o limite de $\mathrm{Cu}$ é de $0.01 \mathrm{mg} / \mathrm{g}$, de $\mathrm{Pb} 0.002 \mathrm{mg} / \mathrm{g}$, de $\mathrm{Cr} 0.001$, de Fe $0.02 \mathrm{mg} / \mathrm{g}$. As amostras de espécies vegetais avaliadas obtiveram valores superiores aos limites permitidos pela organização, evidenciando a possível intoxicação dos consumidores destes vegetais.

É possível observar que os valores encontrados para a concentração de $\mathrm{Pb}$ nas plantas estão acima do limite permitido pela Portaria 685 da ANVISA (BRASIL, 1998) que é de $0,00005 \mathrm{mg} / \mathrm{g}$, e de acordo com a Farmacopeia Europeia o limite máximo de $\mathrm{Pb}$ em plantas medicinais é de $0,005 \mathrm{mg} / \mathrm{g}$.

A presença de Chumbo nas amostras de plantas é um dado importante para a saúde pública, tendo em vista, as características tóxicas deste metal, estudos mostram que está espécie química pode afeta o aparelho gastrintestinal, os rins, o sangue e o sistema nervoso, RADOJEVIC e BASHKIN (1999). No sistema nervoso o metal pode causar neuropatias periféricas, alterações cognitivas e doenças cerebrovasculares, ROSENSTOCK e CULLER, (1994). 0 íon Pb2+ acumula-se no sangue, chegando aos tecidos, particularmente o cérebro, e por fim, pode se fixar nos ossos e substituir os íons Ca2+, BAIRD (1998). Mesmo em pequenas quantidades este metal pode afetar a capacidade do organismo de utilizar outros metais, como por exemplo, $\mathrm{Mg}$ e Ca e outros minerais, pois apresenta características químicas semelhantes de absorção, visto que são todos encontrados na solução do solo como íons bivalentes, contudo, o Pb é um metal de transição considerado tóxico para diversos organismos vivos, WILKE ( 2004). Pesquisas realizadas por Bertoli et al. (2014) submeteram cultivos de Brassica juncea a diferentes concentrações de Pb para avaliar o efeito deste metal, observaram a perda de massa seca, falta de crescimento e a diminuição dos minerais $\mathrm{Mg}, \mathrm{P}, \mathrm{Fe}$ e Zn.

As espécies vegetais Arrabidaea chica (Pariri), Bryophyllum pinnatum (Pirarucu), Plectranthaus ornatos Codd (Boldo chinês) e Aloe vera (Babosa), analisadas nesta pesquisa possuem capacidade de acumular $\mathrm{Pb}$, proveniente do solo em que estas se encontram. Desta forma, pode-se ressaltar a importância da atenção no consumo destas espécies vegetais, haja vista, o elevado nível de toxidez do metal para o ser humano, assim como, o uso destas como bioindicadores de solos contaminados por $\mathrm{Pb}$ e plantas biorremediadoras. De acordo com McBride (2002) o Pb é considerado um dos metais menos móveis no solo e pode ser complexado pela matéria orgânica, em óxidos e minerais de silicato e precipitado como carbonato, hidróxido ou fosfato em condições de alto pH. O autor Haider et al.(2004), ressalta que o $\mathrm{Pb}$, é um elemento denso e solúvel em água podendo desta forma ser facilmente absorvido pelos organismos vivos, a ocorrência de $\mathrm{Pb}$ no solo pode dar-se por fatores naturais ou antropogênicos.

Contudo, é importante a realização de monitoramentos de metais em regiões que fazem uso constante de plantas como alimentos ou para fins medicinais, e que possuem uma extensa diversidade de plantas com ações farmacológicas, CALDAS e MACHADO (2004). É relevante a observação da presença de metais também em solos, visto que, os vegetais absorvem do solo por meio das raízes os metais essenciais e não essenciais, FAQUIN (2005). 


\section{REFERÊNCIAS}

[1] Baird,C. Toxic Heavy Metals, in. Environmental Chemistry. 2 ed. New York: W. H. Freeman And Company. p. 557, 1998.

[2] Baker, A.J.M. And Brooks, R.R. Terrestrial Higher Plants Which Hyperaccumulate Metalic Elements. A Rev. of Their Distrib, Eco. and Phytochem. Bio. 1989; 1: 81-126.

[3] Brasil. Ministério da Saúde, Secretária de Vigilância Sanitária. Portária no 685, de 27 de Agosto de 1998. Diário Oficial da república Federativa do Brasil. 1998.

[4] Caldas, E. D., Machado, L. L. Cadmiun, Mercury and lead in medicinal herbs in Brazil. Food Chem Toxicol. v. 42, p. $599-603,2004$.

[5] Chojnacka, K. Biosorption and Bioaccumulation - the prospects for practical applicatinos. Env. Inter., 2010; 36 (3): $299-307$.

[6] Conselho Nacional do Meio Ambiente. Resolução nợ20. p. 81-84, 2009.

[7] Faquin, V. Nutrição Mineral de Plantas. Lavra: Ufla/Faepe. 2005.

[8] Ferreira, A.P. et al. Avaliação das concentrações de metais pesados no sedimento, na água e nos órgãos de Nycticorax nycticorax (Garça-da-noite) na Baía de Sepetiba, RJ, Brasil. Revista da Gestão Costeira Integrada / Jour. of Integ. Coas. Zone Manag.2010; 10(2):229-241. Doi: 10.5894/rgci186.

[9] Freire, M.F.I. Metais pesados e plantas medicinais. Rev. Cien. de Agro.. 2005.

[10] Haider, S. N. et al. Heavy metal contente in some therapeutically importante medicinal plants. Bull. Env.. Com. Tox.. 2004; 72: 119-127.

[11] Kirkby, E. A.; Romheld, V. Micronutrientes na fisiologia de plantas: Funções, Absorção e Mobilidade. International Plant Nutrition Institute, no 118, p. 1-24, 2007.

[12] Klumpp, A.; et al. Um novo conceito de monitoramento e comunicação ambiental: a rede europeia para a avaliação da qualidade do ar usando plantas bioindicadoras (EuroBionet). Ver. Bra.. Bot. 2001; 24 (4):511-518.

[13] Mcbride, J. M. et al. The effect of heavy- vs. light-load jump squats on the development of strength, power, and speed. J. Strength Cond. Res. v. 16, no 1, p. 75-82, 2002.

[14] Nazir, R. et al. Accumulation of Heavy metals ( $\mathrm{Ni}, \mathrm{Cu}, \mathrm{Cd}, \mathrm{Cr}, \mathrm{Pb}, \mathrm{Zn}, \mathrm{Fe}$ ) in the soil, water and plants na analysis of physico-chemical parameters of soil and water collected from Tanda Dam Kohat. Pham. Sci e Res, 2015; 7 (3): $89-97$.

[15] Oliveira, M. A. P; Parente, R.C. M. Noções básicas de bioestatística. Bras. J. Vid.-Sur. 2010; 4 (1): 1-8.

[16] Radojevic, M.; Bashkin, V. N. Practical environmental analysis. Londres: Royal Society of chemistry, 1999,466 p.

[17] Sarma, H. Metal Hyperaccumulation in Plants: A Review Focusing on Phytoremediation Technology. Jour. of Envir. Scie. and Tech., 2011: 118-138.

[18] Veiga, V.F.J.; et al. Plantas Medicinais: cura segura?. Quím. Nov.. 2005; 28: 519- 428.

[19] World Health Organization. Geneve, p. 224, 2001. 


\section{Capítulo 9}

Composito polimérico de fibra de coco: Análise de tração e mecanismos de falha

Gilmar Alves Borges

Anderson Mathias Pereira

Emerson Cardoso Rodrigues

Nélio Teixeira Machado

Douglas Alberto Rocha de Castro

Lauro Henrique Hamoy Guerreiro

Romero Moreira de Oliveira

Wenderson Gomes dos Santos

Resumo: Os compósitos reforçados com fibras vegetais com matrizes poliméricas tem sido uma área atraente para pesquisadores e indústrias, onde atualmente se torna uma necessidade à agregação de valores aos resíduos gerados pela população, criando materiais alternativos eficientes e de baixo custo, aproveitando os próprios recursos naturais, e preservando o meio ambiente. No presente trabalho, materiais compósitos de matriz poliéster insaturados reforçados por fibras de coco, dispostas aleatoriamente, foram produzidos, com o objetivo de avalia-los quanto ao ensaio de tração e análise de falhas. A matriz de poliéster utilizada foi a ortoftálica pré-acelerada e curada com peróxido de metil-etil-cetona (MEK-P) na proporção em relação à resina de $1 \%$ em volume. Os compósitos foram fabricados por moldagem manual, sem pressão e à temperatura ambiente, posteriormente curada em estufa a $80^{\circ} \mathrm{C}$ por 48 horas. Os compósitos foram avaliados em ensaio de tração e avaliação da superfície fraturada. Para os compósitos, as maiores resistência a tração foram obtidas para fibras tratadas a $0,5 \%$ de $\mathrm{NaOH}$ e $1 \%$ de $\mathrm{NaOH}$. Os mecanismos de falhas presentes na superfície de fratura do compósito polimérico com fibra de coco tratada com $1 \%$ de $\mathrm{NaOH}$ foram 0 pull out (arrancamento de fibras) e o rompimento das fibras. Sendo predominante o rompimento das fibras, evidenciando que com o tratamento ocorreu a maior adesão da fibra a matriz polimérica.

Palavras Chave: Compósitos, Recursos Naturais, Resistência dos materiais 


\section{INTRODUÇÃO}

Podemos definir material compósito como sendo uma combinação macroscópica de dois ou mais materiais de fases distintas, e que apresentam interface entre eles. Para este trabalho, numa definição mais focada, pode-se dizer que compósitos são materiais que contém fase contínua, chamada matriz e que é representada pelo polímero, e a fase dispersa, representada pela fibra de coco. Normalmente a fase dispersa é mais dura e mais resistente que a matriz, e isso alteram as propriedades do polímero (RABELLO, 2000). As propriedades dos compósitos são controladas, principalmente, pelas propriedades de seus materiais constituintes, teor de reforço, grau de dispersão, geometria do reforço, razão de aspecto (relação comprimento/diâmetro) e orientação das fibras. Estas propriedades controlam a homogeneidade do produto.

A interface é a região onde ocorre o contato entre os componentes do compósito, sendo a transferência dos esforços aplicados à matriz, através desta região. A interação entre fibra e matriz resulta numa região com morfologias e composições químicas significativamente distintas, quando comparadas aos cernes da fibra e da matriz (RAZERA, 2006). Apesar dos conhecimentos a respeito da região de interface não serem completos, muitos estudos apontam a aplicação de tratamentos superficiais para modificação química e estrutural das superfícies, buscando melhorar o molhamento e a proteção do reforço, para então proporcionar um melhor desempenho nas propriedades do composto (DAMIANI, 2013).

\section{METODOLOGIA}

As fibras longas foram retiradas de cocos da cidade de Marabá (PA), por meio do desfibramento manual e colocadas em estufa a $100^{\circ} \mathrm{C}$ por $1 \mathrm{~h}$, para retirada da umidade.

\subsection{MATRIZ POLIMÉRICA}

Para a confecção do compósito, foi utilizada como matriz polimérica uma resina poliéster insaturada GAMA 313, fabricada pela Embrapol, do tipo ortoftálica pré-acelerada, adquirida no comércio local. Utilizou-se como catalisador o Peróxido de Metil-Etil-Cetona (MEK-P) em concentração de 1\% em peso.

\subsection{MERCERIZAÇÃO DAS FIBRAS DE COCO}

As fibras foram pesadas e separadas em quatro béqueres, juntamente com a solução de hidróxido de sódio $(\mathrm{NaOH})$, nas concentração de $0,5 \%, 1 \%, 5 \%$ e $10 \%$. Logo em seguida foram colocadas em agitação com o auxílio de um agitador eletromecânico por 1 hora. Terminado o tratamento alcalino, as fibras foram lavadas em água destilada até ser alcançado um pH próximo do neutro, e logo após, direcionadas para estufa com temperatura constante de $100^{\circ} \mathrm{C}$ por duas horas, a fim de remover a umidade. Esse procedimento foi utilizado, para o tratamento das fibras de coco, em todas as concentrações.

\subsection{PREPARAÇÃO DOS COMPOSITOS}

Os corpos de prova foram fabricados por moldagem manual utilizando-se moldes de silicone, sem desmoldante e sem pressão. Os corpos de provas foram preparados utilizando uma fração mássica do reforço (fibra de coco) no valor de 3,90\%. Os moldes de tração foram preenchidos aleatoriamente com o reforço até o limite de sua capacidade volumétrica. Em seguida, adicionava-se a resina poliéster com a adição de catalisador, até alcançar o ponto de gelificação. 0 tempo de endurecimento foi de uma hora, para logo em seguida ser realizado o desmoldamento.

Após o desmolde dos corpos de prova, os mesmos foram submetidos ao processo de pós-cura, sendo colocados em uma estufa por um período de 48 horas à temperatura de $80^{\circ} \mathrm{C}$. Depois de completado o tempo de pós-cura, os corpos de prova foram usinados manualmente para alcançar a forma que determina a norma ASTM D-3039 e depois submetidos a Ensaio mecânico de tração. Foram fabricados cinco corpos de prova para cada experimento, totalizando 30 corpos de prova, com as proporções de agente de cura/resina de $1 \%(\mathrm{v} / \mathrm{v})$. 


\subsection{ENSAIO MECÂNICO DE TRAÇÃO}

Os compósitos foram analisados em uma máquina universal EMIC DL10000 com carga de 20KN, equipado com garras pneumáticas, sob velocidade de $1 \mathrm{~mm} / \mathrm{min}$. Para cada composito, foram analisados, 5 corpos de prova, com dimensões de acordo com a norma ASTM D-3039, com 12,7 mm de largura, $110 \mathrm{~mm}$ de comprimento e 2,7 mm de espessura.

\section{RESULTADOS E DISCUSSÕES}

\subsection{RESISTÊNCIAS A TRAÇÃO DOS COMPÓSITOS}

Analisando a figura 01, observa-se que os compósitos constituídos com fibras de coco tratadas com 0,5\% e $1 \%$ de $\mathrm{NaOH}$, proporcionaram um aumento na resistência a tração devido a retirada da lignina, hemicelulose e ceras das fibras, ocasionando uma melhor adesão entre fibra e matriz.

Figura 01:Gráficos força x deformação dos corpos de prova analisados

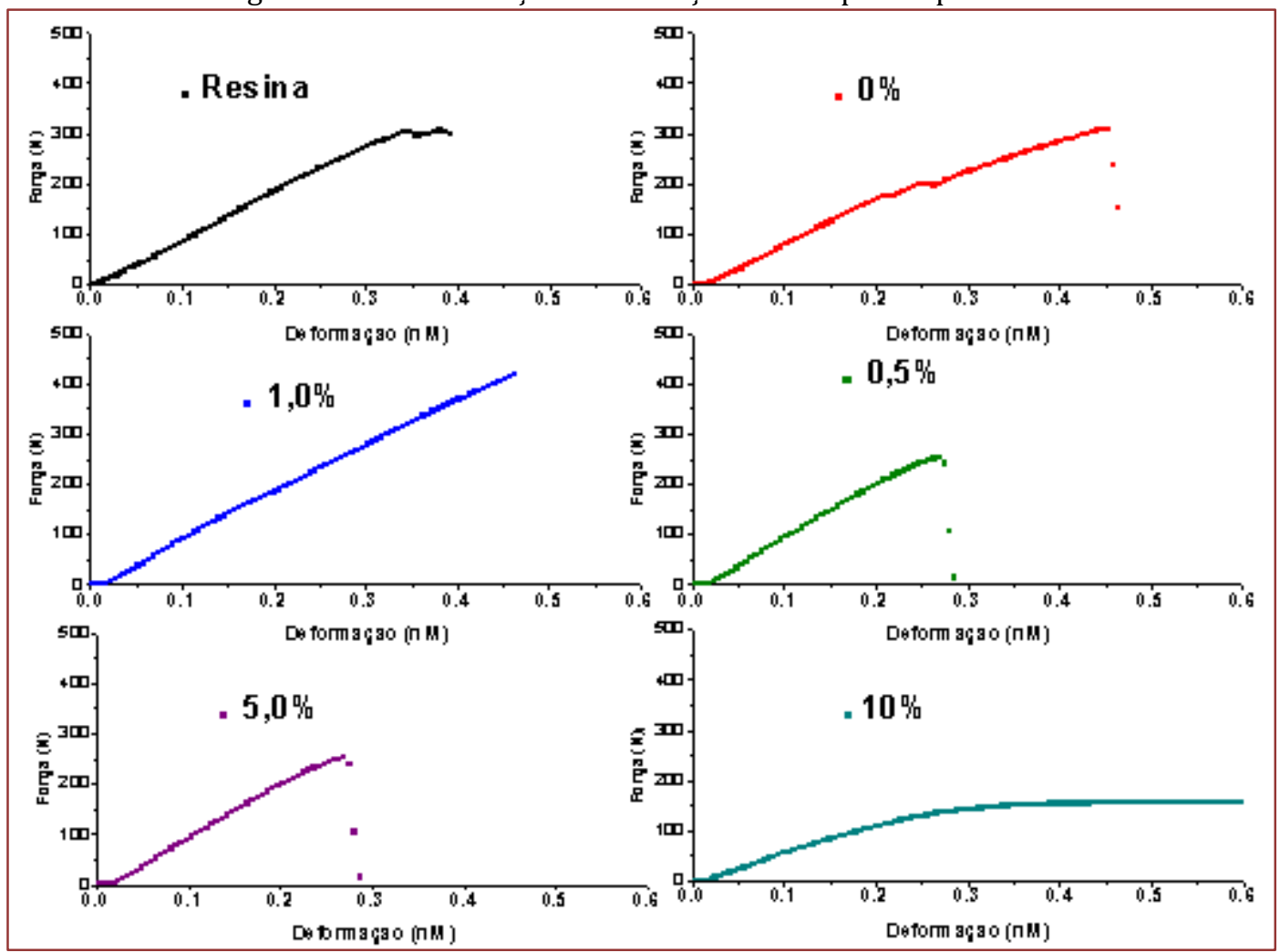

Constatou-se ainda, que o compósito com fibra de coco tratada com 1\% de hidróxido de sódio possui a maior resistência a tração entre os compósitos estudados, pois, esta composição proporcionou uma maior retirada de ligninas, hemiceluloses e ceras, sem degradar a celulose.

Nos compósitos com fibra de coco tratadas a 5\% e 10\% de $\mathrm{NaOH}$, observou-se que a resistência a tração diminui devido o tratamento ter retirado eficientemente a lignina, mas degradado a celulose. Infere-se que a inserção de fibra de coco na matriz polimérica de poliéster insaturado resulta em um aumento da resistência a tração, exceto nos casos com fibra de coco tratadas com 5\% e 10\% de NaOH. 


\subsection{ANÁLISES DE FALHA DO COMPÓSITO}

Na análise de falha escolheu-se o compósito reforçado com fibra tratada a 1\% de hidróxido de sódio, pois este apresentou os melhores resultados de resistência à tração.

Conforme visualizado na figura 02, verificou-se que o mecanismo de falha presente é tanto pull out (arranchamento das fibras), quanto por presença de fibras rompidas.

0 mecanismo de fratura predominante é de fibras rompidas, mostrando que este compósito possui boa interação fibra-matriz.

Figura 02 - Superfície de fratura do compósito com fibras tratadas a $1 \%$ de $\mathrm{NaOH}$.

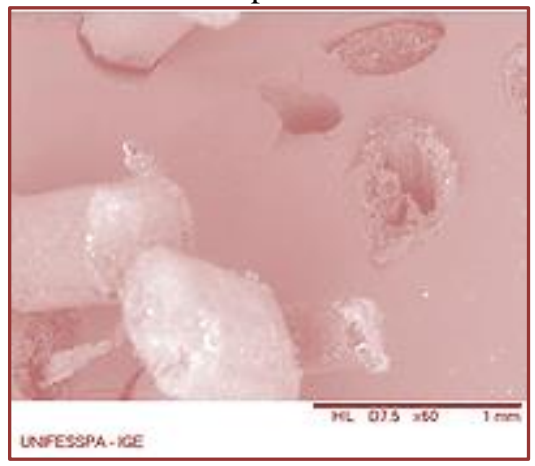

\section{CONCLUSÃO}

Ficou evidenciado através do ensaio de tração, que a adição das fibras de coco na matriz polimérica, melhora a resistência do compósito, exceto nas fibras com tratamento a $5 \%$ e $10 \%$ de $\mathrm{NaOH}$, que devido a degradação da celulose, ocasiona a formação de falhas no compósito.

Na análise microscópica da superfície de fratura do compósito reforçado com fibras tratadas com hidróxido de sódio na concentração de $1 \%$, foi evidenciado que o tratamento proporcionou uma maior adesão fibra-matriz principalmente pela predominância de rompimento de fibras sobre arrancamento da mesma.

Portanto, ficou evidenciado, que a adição de fibra de coco tratada quimicamente com hidróxido de sódio na concentração de $1 \%$ na matriz polimérica, melhora sua adesão fibra-matriz e consequentemente a resistência à tração.

\section{REFERÊNCIAS}

[1] American Society For Testing And Materials - ASTM - D3039/D3039, 2000 - Standard test method for tensile properties of polymer matrix composite materials. USA.

[2] Damiani, R. A. Estudo do efeito de parâmetros de processamento por injeção nas propriedades mecânicas do nanocompósito de poliamida/fibra de vidro/motmorilonita. Dissertação (Mestrado Ciência e Engenharia de Materiais). 2013. Criciúma/SC. 2013.

[3] Rabello, M. Aditivação de Polímeros. São Paulo : Artiliber Ed. 2000.

[4] Razera, I, A, T. Fibras lignocelulósicas como agente de reforço de compósitos de matriz fenólica e lignofenólica. Tese (Doutorado em Ciências (físico-quimica)). Universidade Federal São Carlos, 2006. 


\section{Capítulo 10}

Estudo da influência da sedimentação gravitacional da lama vermelha na resistência à chamas de Compósitos Poliméricos

Haianny Beatriz Saraiva Lima

Bruno Henrique Alves Mendes

Julianne Silva Lalor

Karla Suellen Lino Barbosa

Wassim Raja El Banna

Deibson Silva da Costa

Resumo: 0 Estado do Pará é um dos maiores produtores de substâncias minerais do Brasil, como consequência vários resíduos são gerados conforme a produção, isso ocasiona enormes impactos ambientais, sendo assim necessário fornecer uma utilidade para esses resíduos. Esse trabalho tem como objetivo avaliar a influência da sedimentação gravitacional da lama vermelha nos compósitos poliméricos através dos ensaios de flamabilidade (IEC 60695-11-10 e ASTM D635). A lama vermelha passou por várias classificações granulométricas, utilizou-se a resina poliéster isoftálica, iniciador $(1,5 \% \mathrm{v} / \mathrm{v})$ e acelerador de cobalto (1\% v/v), estipulou-se as frações mássicas de $40 \%$ e $20 \%$ para cada camada (sedimentada e suspensão), respectivamente. A fabricação dos compósitos foi realizada por moldagem manual em molde de silicone. Os compósitos apresentaram capacidade de resistência à chama, sendo que os compósitos de 40 \% de lama vermelha sedimentada e em suspensão apresentaram melhor desempenho em relação à matriz plena. 


\section{INTRODUÇÃO}

A produção mineral é, indubitavelmente, a principal atividade econômica do Estado do Pará, tanto que o Banco Mundial qualificou sua economia como essencialmente mineira (Silva et al., 1996). Muitas das nossas tecnologias modernas exigem materiais com combinações não usuais de propriedades as quais não podem ser atendidas pelas ligas metálicas, cerâmicos e materiais poliméricos convencionais. As combinações e as faixas das propriedades dos materiais foram, e ainda estão sendo ampliadas pelo desenvolvimento de materiais compósitos. De acordo com o princípio da ação combinada, melhores combinações de propriedades são criadas por uma combinação judiciosa de dois ou mais materiais distintos (Callister, 2008).

Várias pesquisas são realizadas visando o aproveitamento de resíduos, para assim diminuir os impactos ambientais causados, segundo as pesquisas de Rodrigues (2016), El Banna (2017) e Cunha (2015). 0 resíduo gerado em uma das etapas do processo Bayer (Lama vermelha), é normalmente disposto em grandes lagoas de sedimentação, as quais geram enormes impactos ambientais.

Visto a gravidade dos impactos ambientais que podem ser gerados por esses resíduos, faz-se necessário fornecer uma utilidade nobre, neste contexto esse trabalho tem como objetivo avaliar a influência da sedimentação gravitacional da lama vermelha nos ensaios de flamabilidade em compósitos com incorporação de lama vermelha.

\section{MATERIAIS E MÉTODOS}

A matriz utilizada no desenvolvimento deste trabalho é composta por um polímero termofixo (resina poliéster isoftálica insaturada), acelerador de cobalto na proporção 1,5\% (v/v) e iniciador MEK-P (Butanox M-50) utilizado na proporção $1 \%$ (v/v). A lama vermelha foi obtida através das indústrias locais do estado do Pará. Determinou-se a massa do resíduo a ser utilizado para a fabricação em uma das frações mássicas de $20 \%$ e $40 \%$.

A lama vermelha (LV) bruta foi secada na estufa com temperatura de $100{ }^{\circ} \mathrm{C}$ por 24 horas, em seguida desagregou-se em um moinho de bolas por aproximadamente 30 minutos. A LV foi classificada utilizando uma peneira de 100 Mesh da série Tyler (tamanho da abertura 0,147 mm), para depois classificar-se a úmido em peneira de $325 \mathrm{Mesh}(0,044 \mathrm{~mm})$. Secou-se o material passante para ser feita novamente a sua desagregação e classificação em peneira de 100 Mesh $(0,147 \mathrm{~mm})$. Realizou-se a sedimentação gravitacional por 1 hora, onde foram formadas duas camadas: sedimentada e em suspensão. As duas camadas foram separadas e secas por 24 horas, para ser feita novamente a desagregação de ambos e classificação em peneira de 100 Mesh.

As proporções de cobalto e butanox foram medidas e o resíduo de LV foi pesado e levado à estufa à aproximadamente $100^{\circ} \mathrm{C}$ por 20 minutos. A mistura manual de resina, cobalto, resíduo e iniciador durou cerca de 5 minutos, após essa etapa a mistura foi despejada no molde de silicone, esperou-se 1 hora para a retirada dos corpos de prova (CP'S) que foram colocados em um recipiente plano por 24 horas para evitar possíveis deformações. Fabricou-se 10 corpos de prova em molde de silicone de cada fração mássica com $20 \%$ e $40 \%$ de LV, fração sedimentada e em suspensão, para os ensaios de flamabilidade. Os corpos de prova foram lixados para os devidos acabamentos e identificados em suas duas extremidades. A Figura 1 apresenta um fluxograma com as principais etapas de fabricação deste trabalho. 
Figura 1 - Fluxograma das etapas de fabricação dos materiais compósitos.

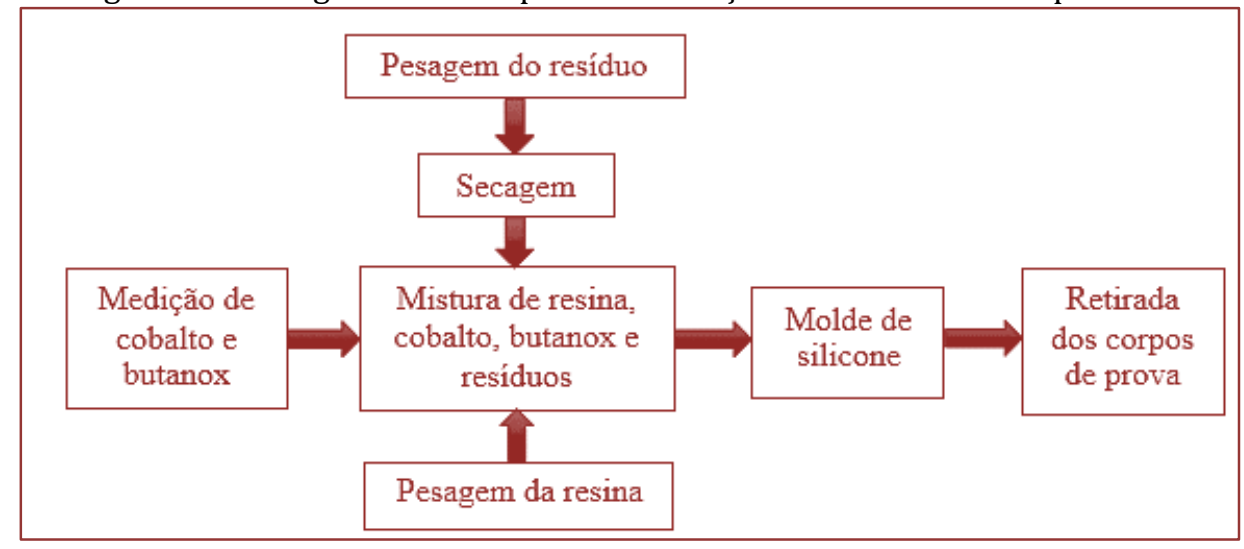

\section{RESULTADOS E DISCUSSÕES}

Utilizou-se o ensaio de flamabilidade especificado nas normas IEC 60695-11-10 e ASTM D635, efetuado na posição horizontal, onde registrou-se o tempo necessário para a combustão atingir a marca de $25 \mathrm{~mm}$ (1 polegada) e o tempo necessário para atingir a marca de $100 \mathrm{~mm}$ (4 polegadas) quando a combustão prosseguia. Por fim para os CP'S que não atingiram a marca de $100 \mathrm{~mm}$, registrou-se o tempo e o comprimento danificado.

Os dados obtidos para os resíduos de lama vermelha (LV), sedimentada (SED) e em suspensão (SUS), nas proporções mássicas de 40 \% e 20 \%, juntamente com a resina plena são observados na Tabela 1.

Tabela 1 - Resultados do ensaio de flamabilidade
\begin{tabular}{|c|c|}
\hline COMPOSIÇÃOO & TAXA $(\mathrm{mm} / \mathrm{min})$ \\
\hline RESINA PLENA & $27,3( \pm 0,54)$ \\
\hline $20 \% \mathrm{LV}$ - SUS & $14,56( \pm 2,82)$ \\
\hline $20 \% \mathrm{LV}-$ SED & $13,03( \pm 0,11)$ \\
\hline $40 \% \mathrm{LV}-$ SUS & SI \\
\hline $40 \% \mathrm{LV}$ - SED & SI \\
\hline
\end{tabular}

Os corpos de prova com fração mássica de $40 \%$ apagaram a chama antes de atingir a linha de $75 \mathrm{~mm}$ estipulada pela norma, esses CP'S foram classificados como SI (sem ignição). Já os de $20 \%$ houve a propagação da chama, porém com velocidade de propagação significativamente reduzida.

De acordo com a tabela de resistência a chama da norma HB (horizontal burning ou teste de flamabilidade horizontal), valores inferiores a $40 \mathrm{~mm} / \mathrm{min}$ são classificados como adequados. Logo, os resultados obtidos pelos compósitos contendo somente a resina plena e os que foram adicionados o resíduo de lama vermelha apresentaram excelentes resultados, visto que a taxa média de queima dos corpos de prova diminuiu conforme acrescentou-se o resíduo.

No Brasil a resolução CONTRAN no 675, exige que os revestimentos internos das indústrias automobilísticas tenham uma velocidade de propagação de chama de $250 \mathrm{~mm} / \mathrm{min}$. Já nos países com pesquisas avançadas nessa área, esse valor é de $80 \mathrm{~mm} / \mathrm{min}$ (Ribeiro, L. M., 2013).

A Figura 2 apresenta o gráfico comparativo dos resíduos de lama vermelha em comparação a matriz plena (MP) e suas taxas de queima, onde pode ser notada a diferença entre os resultados obtidos. 
Figura 2 - Gráfico comparativo dos resíduos de lama vermelha em relação à matriz plena, através do ensaio de flamabilidade.

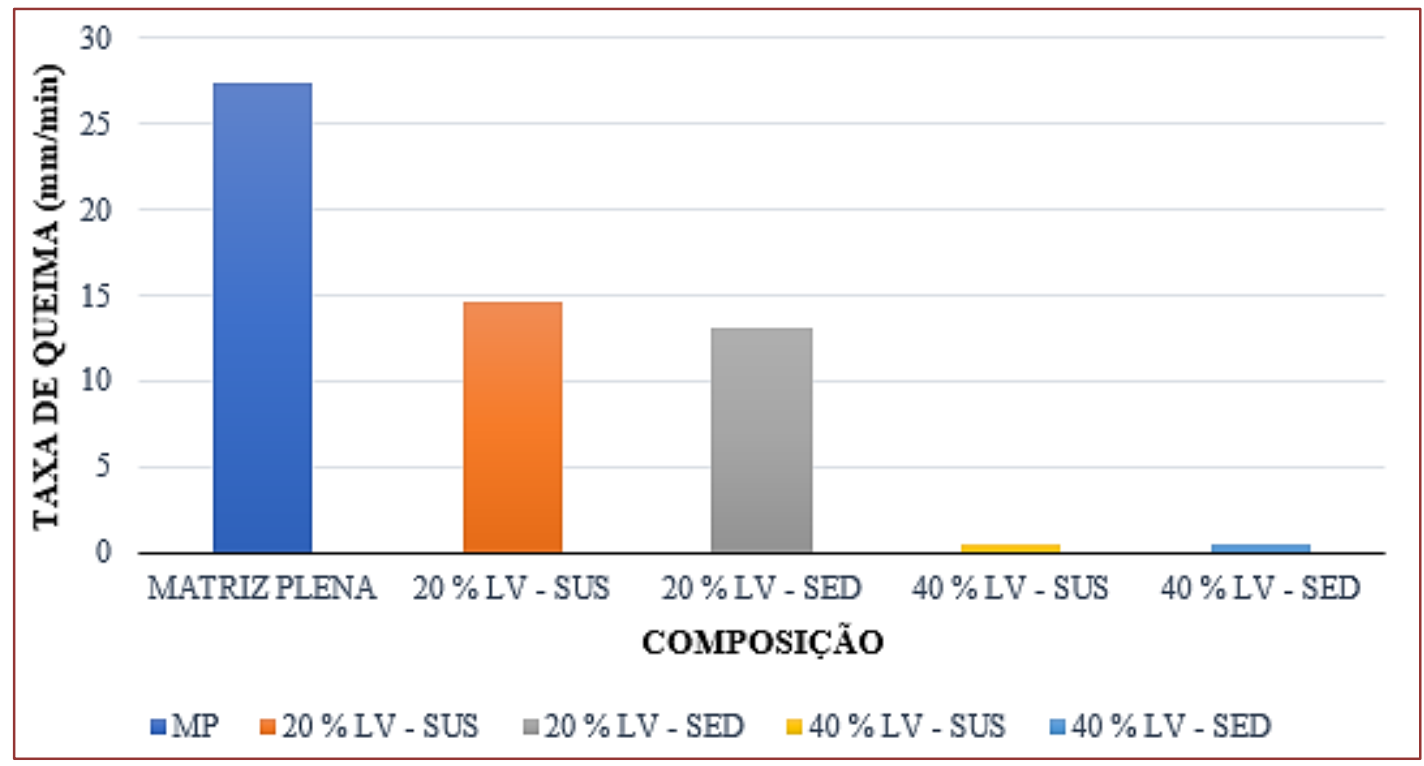

A incorporação de particulados inorgânicos, com baixa flamabilidade, pode atuar na redução da quantidade de material combustível disponível para a propagação, o que explicaria a progressiva redução na taxa em função do aumento no teor de particulado (Ullah et al., 2014).

Segundo Ribeiro et al. (2013), neste ensaio observou-se que o tempo médio de queima das amostras aumentou à medida que se adicionou mais resíduo ao compósito, demonstrando que quanto maior for o tempo de queima do material, menor será a velocidade de queima, o que dificulta a propagação da chama e facilita a extinção da mesma.

Um dos mais comuns mecanismos de retardância à chama é a liberação de água estrutural de óxidos hidratados ao atingirem suas temperaturas de desidratação correspondente (Cunha 1998).

A lama vermelha contém em sua composição química alguns óxidos $\left(\mathrm{Al}_{2} \mathrm{O}_{3}, \mathrm{Fe}_{2} \mathrm{O}_{3}, \mathrm{SiO}_{2}, \mathrm{TiO}_{2}, \mathrm{CaO}, \mathrm{Na}_{2} \mathrm{O}\right.$, $\mathrm{MnO}, \mathrm{MgO}$ ), sendo metade da composição constituída por óxidos de alumínio e óxidos de ferro. Algumas pesquisas envolvendo óxidos metálicos constataram retardância de chamas para materiais como MnO e $\mathrm{Fe}_{2} \mathrm{O}_{3}$. De acordo com Utstester (2010), o hidróxido de alumínio, material retardador de chama é excelente para o meio ambiente e não produz gases tóxicos, já o óxido de magnésio metálico após ser aquecido liberando água, pode absorver o calor e assim, atingir o objetivo de retardador de chama.

Cunha (2015), após a utilização do método de difração de raio-X (DRX), que permite a determinação mineralógica dos materiais, notou a presença de picos correspondentes a hematita $\left(\mathrm{Fe}_{2} \mathrm{O}_{3}\right)$, goetita $(\mathrm{FeO}$ $(\mathrm{OH})$ ), gibbisita $\left(\mathrm{Al}(\mathrm{OH})_{3}\right)$, sodalita $\left(\mathrm{NaAlSi}_{4} \mathrm{O}_{12} \mathrm{Cl}\right)$, caulinita $\left(\mathrm{Al}_{6} \mathrm{Si}_{2} \mathrm{O}_{2}-(\mathrm{OH})_{4}\right)$ e chantalita $\left(\mathrm{CaAl}_{2} \mathrm{SiO}_{4}\right.$ $\left.(\mathrm{OH})_{4}\right)$.

\section{CONCLUSÃO}

Através dos ensaios de flamabilidade notou-se que conforme acrescentava-se o resíduo de lama vermelha na matriz polimérica, a velocidade de propagação da chama foi significativamente reduzida.

A sedimentação gravitacional permitiu a separação em 2 (duas) camadas de lama vermelha, sedimenta e suspensão, porém, não gerou alterações significativas nos compósitos, sendo necessário mais testes para analisar a sua influência.

Os materiais fabricados após o ensaio de flamabilidade classificaram-se conforme a norma HB referindo à norma ASTM D 635, como retardante de chama. Os compósitos utilizando resíduos de vermelha obtiveram resultados satisfatórios.

De acordo com o CONTRAN no 675, em relação aos resultados obtidos, os compósitos estudados apresentaram valores bem menores do que o exigido pelas normas. Logo os materiais desenvolvidos nesse 
trabalho, podem ser aplicados como retardante a chama, dando assim uma utilização para esses resíduos que seria descartado ocasionando grandes impactos ambientais. A segurança é outro fator importante, visto que um material que extingue ou retarde a chama, pode em determinadas situações, salvar vidas, assim como proporcionar a diminuição de gases poluentes gerados pela queima do material.

\section{REFERÊNCIAS}

[1] American Society for Testing and Materials Astm D635-10 - Standard Test Method for Rate of Burnin or Extent and Time of Burning of Plastics in a Horizontal Position.

[2] Callister, W. D. Jr. Ciência e engenharia de materiais: uma introdução. Rio de Janeiro: LTC, 2008.

[3] Cunha, E. J. S. Influência do uso de resíduo do processo Bayer nas propriedades térmicas e mecânicas de compósitos de base polimérica reforçados com fibra de Curauá. Tese de doutorado, 2015.

[4] Cunha, E. J. S. Degomagem de feixe de fibras de curauá (Ananas erectifolius S.) Influência das variáveis de processos na solubilidade do material péctico e nas propriedades mecânicas. 1998, 64 p. Dissertação (Mestrado em Engenharia Química). Universidade Federal do Pará, Belém-PA, 1998.

[5] El Banna, W. R. Influência do resíduo de flotação de minério de cobre nas propriedades físicas e mecânicas de compósitos de matriz termofixa e fibras de bananeira (Musa Sapientum, Musacae). Tese de doutorado, 2017.

[6] Iec 60695-11-10 ed2.0 - Fire hazard testing - Part 11-10: Test flames - $50 \mathrm{~W}$ horizontal and vertical flame test methods.

[7] Rodrigues, D. N. Influência da adição de resíduo de mármore e granito em compósitos de matriz polimérica reforçados com fibra de coco. Dissertação de mestrado, 2016.

[8] Ribeiro, L. M. Flamabilidade e retardância de chama do compósito: poliéster insaturado reforçado com fibra de abacaxi (palf). Holos, ano 29, vol 1, 2013.

[9] Silva, A.; Stilianidi, F. B.; Braga, J. B. P.; Azevedo, L. O R. Pará: a maior província mineral da terra. Revista Nosso Pará, Belém, n. 3, p. 78-89, dez. 1996.

[10] Ullah, S.; Ahmad, F.; Shariff, A. M.; Bustam, M. A. Synergistic effects of kaolin clay on intumescent fire retardant coating composition for fire protection of structural steel substrate. Polymer Degradation and Stability, v. 110, p. 91-103, 2014

[11] Utstester. Classificação de material retardador de chama. Disponível em: < https://pt.utstesters.com/blog/flame-retardant-material-classification_b47 >. Acesso em: 24 jul. 2019. 


\section{Capítulo 11}

Artesanato da Amazônia: Viabilidade da utilização de rejeito da Indústria de Cerâmica Vermelha para a produção de utilitários no Polo Artesanal de Icoaraci, Bélem - PA

Gabriel da Silva Gomes

Dayana Rosy Souza dos Santos

Daniel José Lima de Sousa

Dorivane Cohen Farias

Maycon Ruan Pinheiro de Oliveira

Silvio Bispo do Vale

Yuri Ribeiro de Ribeiro

Wilson Guimarães Saraiva

Reginaldo Saboia de Paiva

Resumo: Visando a obtenção de utensílios com melhores propriedades no polo cerâmico artesanal de Icoaraci, este trabalho teve por objetivo avaliar o efeito da incorporação de chamote à argila. 0 chamote foi obtido através do rejeito de artefatos cerâmicos, danificado pós queima. 0 rejeito foi triturado e peneirado. $\mathrm{Na}$ argila empregada para a fabricação das peças, foram determinados a composição química e mineralógica através de FRX e DRX. Após as análises foram adicionados chamote à argila, em porcentagens em massa de 5, 10, 15 e 20\% preparando-se corpos-de-prova com cada uma dessas misturas. Nesses corpos-de-prova foram determinadas algumas propriedades tecnológicas. A argila apresentou composições que englobam características de matérias primas atualmente utilizadas nos produtos cerâmicos brasileiros. Foi observado que a composição de 15\% de chamote seria mais adequada, devido valores de retração linear, perda de massa ao fogo, absorção de água e porosidade aparente serem menores que as demais composições. 


\section{INTRODUÇÃO}

Ao se buscar pesquisas que comprovam vantagens em trabalhar com a adição de chamote na massa cerâmica, é evidente que o objetivo principal é alcançar um material que tenha melhores propriedades mecânicas e térmicas, tenha um custo de produção mais baixo e valorizando o produto final, que respeite a necessidade do meio ambiente, degradando menos, em relação aos demais materiais convencionais (GOMES, 2018). 0 aproveitamento do chamote obtido da fragmentação ou moagem dos utilitários descartados é pouco utilizado no Brasil, ressaltando-se a necessidade de pesquisas na área de massa para a fabricação de refratários utilitários. De acordo com Menezes et al. (2002), a utilização de rejeitos industriais para a produção de materiais alternativos tem dado certo em vários países desenvolvidos; as principais razões para a reciclagem desses rejeitos seriam o esgotamento das reservas de matérias-primas confiáveis, o crescente volume de resíduos sólidos, que põem em risco a saúde pública, ocupa o espaço e degradam os recursos naturais.

\section{MATERIAIS E METODOLOGIA}

\subsection{MATERIAIS}

O material caracterizado foi a argila que é localizada no bairro do Paracuri em Icoaraci, Belém - Pa. E para a produção do chamote, foi utilizado rejeito de artefatos cerâmicos da própria localidade.

\subsection{METODOLOGIA}

0 procedimento experimental envolveu: beneficiamento e seleção das matérias-primas (amostragem); caracterização das matérias-primas (argila e chamote); por produção dos corpos de prova (foram adotados dois tipos de corpos de prova); queima dos corpos de prova; determinação das propriedades físicas e térmicas da cerâmica. A preparação dos corpos de provas (C.P's) de forma a obter resultados compatíveis com as peças obtidas pelos artesãos revelou-se como primeiro problema a ser abordado. Era importante ter uma forma de avaliar como a preparação da massa e sua forma de modelagem influenciava nas propriedades das peças. Desta forma, optou-se por duas formas de modelagem. Para o estudo da matéria prima, trabalhou-se com a prensagem em molde metálico. Esta forma permitiu a obtenção de C.P com dimensões adequadas a determinados ensaios, tais como, Absorção de Água, Retração de Queima, etc. É importante ressaltar que a conformação foi manual, uma vez que o uso de prensa traria resultados díspares dos obtidos pelos artesãos. Por fim, considerou-se ainda de extrema importância estudar peças com formas semelhantes às trabalhadas pelos artesãos, a exemplo do estudo de Weber e colaboradores (2002). Neste caso, priorizou-se as em forma de cuias, que se aproximam das panelas, travessas, etc. Estes C.P. foram modelados manualmente com auxílio de oleiros e foi avaliado o tempo de secagem, a existência de gradientes de umidade, a facilidade de modelagem das peças, bem como seu comportamento de queima (aparecimento de trincas e rachaduras, deformação da peça, etc.) e sua habilidade em armazenar água (o que está diretamente relacionado à porosidade da peça). As duas formas de modelagem mostraram úteis e necessárias ao estudo de peças cerâmicas artesanais.

As medidas foram realizadas em um Difratômetro de Raios-X modelo X'PERT PRO MPD (PW 3040/60) da PANalytical, com Goniômetro PW3050/60 (Theta/Theta), tubo de Raios - X cerâmico e anodo de cobre (K $\alpha 1=1,540598 \AA$ ̊̊), modelo PW3373/00 com foco fino longo (2200W-60kV) e filtro K $\beta$ de níquel. 0 detector utilizado é o X'Celerator, do tipo RTMS (Real Time Multiple Scanning), atuando no modo Scanning e com um active length de $2,122^{\circ}$. As condições instrumentais utilizadas foram: varredura de $5^{\circ}$ a $100^{\circ} \mathrm{em}$ 20; voltagem de $40 \mathrm{kV}$ e corrente de $30 \mathrm{~mA}$; tamanho do passo: $0,02^{\circ}$ em $2 \theta$ e $60 \mathrm{~s}$ o tempo/passo; fenda divergente de 1/8 o e anti espalhamento de 1/4우 ; máscara de $10 \mathrm{~mm}$; amostra em movimentação circular com frequência de 1 rotação/s. 0 software usado na coleta dos dados foi o X-Pert Data Collector, versão 2.1a, e o software usado na identificação de fases cristalinas foi o X-Pert High Score versão 2.1b, ambos da PAnalytical.

As análises químicas seriam realizadas por meio de fluorescência de raios X (FRX), com amostras contendo granulometria inferior a 200\# (mesh), utilizando-se um espectrômetro por fluorescência de raios X do modelo EDX-700, da marca Shimadzu, os dois equipamentos estão localizados no Laboratório de Caracterização Mineral (LCM), do Instituto de Geociências da Universidade Federal do Pará. 


\section{RESULTADOS E DISCUSSÕES}

\subsection{DIFRAÇÕES DE RAIOS X DAS MATÉRIAS-PRIMAS.}

A Figura 1 apresenta o difratograma de raios X das lâminas orientadas da argila de Icoaraci. São observadas como fases cristalinas presentes caulinita, quartzo, e minerais esmectícios. Os picos predominantes são referentes à muscovita $\left[\left(\mathrm{KAl}_{2.20}\left(\mathrm{SI}_{3} \mathrm{Al}\right)_{0.97} \mathrm{O}_{10}\left((\mathrm{OH})_{1.72} \mathrm{O}_{0.28}\right)\right]\right.$ e ao quartzo $\left(\mathrm{SiO}_{2}\right)$. Os minerais esmectícios são minerais acessórios presentes na argila de Icoaraci.

Figura 1 - Difratograma de raios X da argila na forma de lâminas orientadas.

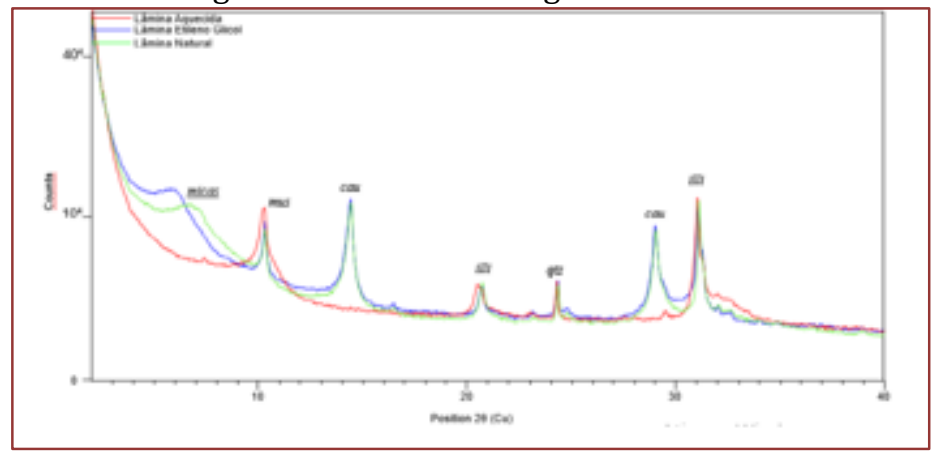

Nota: mus= muscovita; cau= caulinita; illi= ilita; qtz= quartzo; micas= micáceos não definidos .

Devido os planos não estarem bem definidos, o pico definido como micas, está relacionado aos argilominerais micáceos. Foi estabelecido devido seu comportamento ao etileno glicol e após o aquecimento a $550^{\circ} \mathrm{C}$. A argila apresenta picos de difração correspondentes da caulinita $\left(\mathrm{Al}_{2} \mathrm{O}_{3} .2 \mathrm{SiO}_{2} .2 \mathrm{H}_{2} \mathrm{O}\right)$, quartzo $\left(\mathrm{SiO}_{2}\right)$ muscovita e feldspato. A caulinita é responsável pelo desenvolvimento da plasticidade em mistura com água e ainda apresenta comportamento refratário de queima. 0 quartzo é uma impureza natural das argilas e atua como um material não plástico no sistema água/argila. Na Figura 2, são observados picos de difração correspondentes da caulinita - $\mathrm{Al}_{2} \mathrm{O}_{3} .2 \mathrm{SiO}_{2} .2 \mathrm{H}_{2} \mathrm{O}$, quartzo - $\mathrm{SiO}_{2}$ e mica muscovita - $\mathrm{K}_{2} \mathrm{O}_{3} 3 \mathrm{Al}_{2} \mathrm{O}_{3} .6 \mathrm{SiO}_{2} .2 \mathrm{H}_{2} \mathrm{O}$. É importante ressaltar que na análise química (Tab.1) é encontrado um determinado teor de óxido de ferro $\left(\mathrm{Fe}_{2} \mathrm{O}_{3}\right)$, devido ter ocorrência de ferro livre e amorfo na argila estudada.

Figura 2 - Difratograma da argila pelo método do pó sem orientação preferencial.

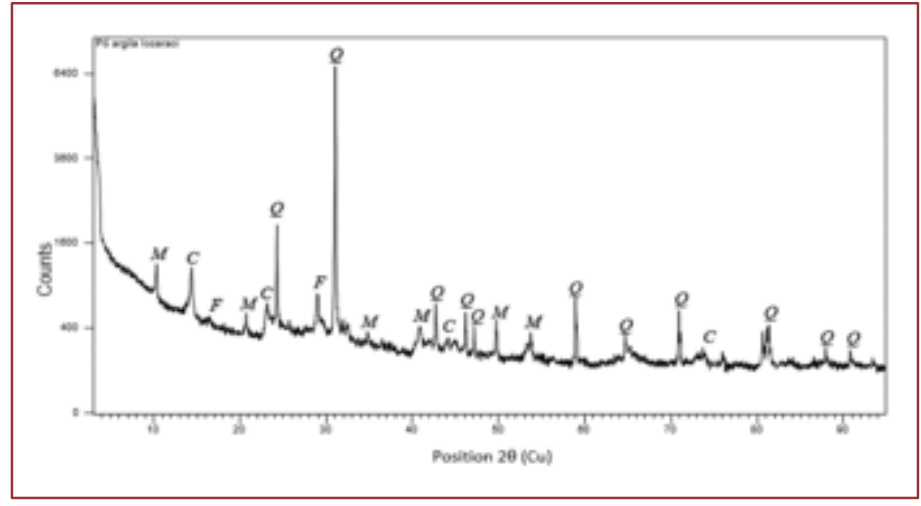

Nota: $\mathrm{M}=$ muscovita; $\mathrm{C}=$ caulinita; $\mathrm{F}=$ feldspato; $\mathrm{Q}=$ quartzo.

O chamote apresenta granulometria com maior fração "areia" o que pode contribuir para ajustar a plasticidade da argila, facilitar a secagem e reduzir a retração das peças. Assim gerando a menores defeitos de secagem e queima, e ainda diminuindo a absorção de água. Devido a temperatura de queima dos materiais produzidos serem inferiores a $600 \stackrel{\circ}{\circ}$, não houve preocupação com aparecimento de trincas de resfriamento causados por transformação alotrópica do quartzo, que é acompanhada com a redução de volume (QUEIROZ, MONTEIRO, VIEIRA, 2010). A análise por difratograma de raios X, Figura 3, revela que o chamote apresenta como fase cristalina predominante quartzo e micas. Além disso, podem-se observar pequenos picos de hematita, bem como a presença mínima de caulinita, o que evidencia que o chamote foi 
obtido de peças que não tiveram sua temperatura de queima superior a $600^{\circ}$. Acima dessa temperatura a caulinita perde sua água de constituição transformando-se numa fase amorfa, a metacaulinita (VIEIRA, 2004).

Figura 3 - Difratograma do chamote.

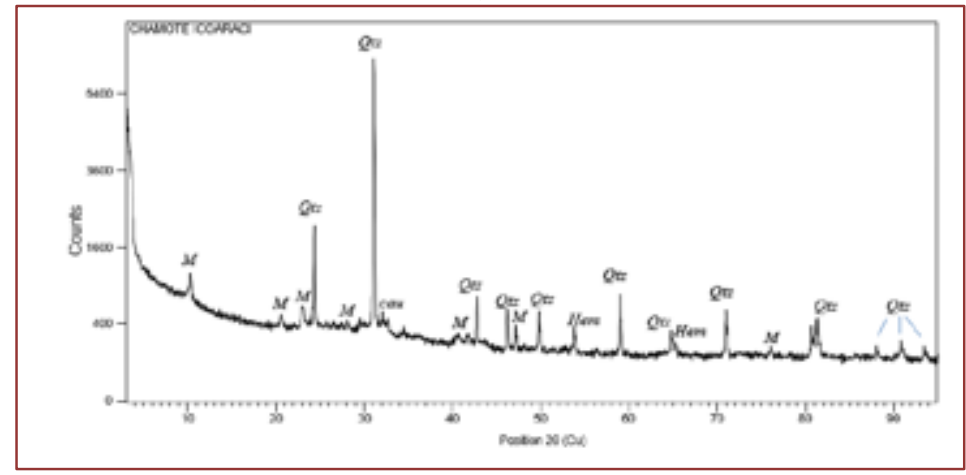

Nota: Qtz= quartzo; M= minerais micáceos não definidos; Hem= hematita; cau= caulinita.

\subsection{ANÁLISE QUÍMICA DAS MATÉRIAS-PRIMAS.}

A Tabela 1 apresenta a composição química da argila. É possível observar que a argila é predominantemente constituída de $\mathrm{SiO}_{2}$ e $\mathrm{Al}_{2} \mathrm{O}_{3}$, os quais estão em sua maior parte combinados formando os aluminosilicatos como a mica muscovita e a caulinita, por exemplo. 0 teor de óxido de ferro confere uma coloração avermelhada ao produto após a queima. Os óxidos alcalino-terrosos $\mathrm{CaO}$ e $\mathrm{MgO}$ estão presentes na estrutura da mica muscovita e eventualmente na montmorilonita. O óxido alcalino $\mathrm{K}_{2} \mathrm{O}$ é fundente muito ativo e tem como finalidade à formação de fase líquida, necessária para uma densificação acentuada da cerâmica após a queima com consolidação das partículas.

Tabela 1 - Composição química da argila

\begin{tabular}{|c|c|c|c|c|c|c|c|c|c|}
\hline & & & & ARGIL & & & & & \\
\hline COMPONENTE & $\mathrm{SiO}_{2}$ & $\mathrm{Al}_{2} \mathrm{O}_{3}$ & $\mathrm{Fe}_{2} \mathrm{O}_{3}$ & $\mathrm{~K}_{2} \mathrm{O}$ & $\mathrm{TiO}_{2}$ & $\mathrm{MgO}$ & $\mathrm{CaO}$ & $\mathrm{MnO}$ & $\mathrm{PF}$ \\
\hline$\%$ & 55,70 & 21,50 & 6,21 & 2,47 & 1,34 & 3,23 & 0,14 & 0,13 & 8,43 \\
\hline TRAÇOS & $\mathrm{Cl}, \mathrm{Cr}$ & $\mathrm{Sr}, \mathrm{Rb}$ & & & & & & & \\
\hline
\end{tabular}

A perda ao fogo (PF) ocorre principalmente devido à perda de água de constituição dos argilominerais, desidratação de hidróxidos, oxidação de matéria orgânica e decomposição de carbonatos (GOMES, 2018). 0 chamote utilizado apresentou elevada concentração de $\mathrm{SiO}_{2}(62,2 \%), \mathrm{Al}_{2} \mathrm{O}_{3}(19,6 \%)$ e $\mathrm{Fe}_{2} \mathrm{O}_{3}(6,85 \%)$ devido à natureza argilosa das matérias-primas na produção dos utilitários como mostra a Tabela 2.

Tabela 2 - Composição química do chamote

\begin{tabular}{|c|c|c|c|c|c|c|c|c|c|}
\hline & \multicolumn{9}{c}{ CHAMOTE } \\
COMPONENTE & $\mathrm{SiO}_{2}$ & $\mathrm{Al}_{2} \mathrm{O}_{3}$ & $\mathrm{Fe}_{2} \mathrm{O}_{3}$ & $\mathrm{~K}_{2} \mathrm{O}$ & $\mathrm{TiO}_{2}$ & $\mathrm{MgO}$ & $\mathrm{CaO}$ & $\mathrm{MnO}$ & $\mathrm{PF}$ \\
\hline$\%$ & 62,20 & 19,60 & 6,85 & 2,11 & 1,30 & 1,21 & 0,21 & 0,24 & 5,79 \\
\hline TRAÇOS & $\mathrm{Cl}, \mathrm{Cr}$ & $\mathrm{Sr}, \mathrm{Rb}$ & & & & & & & \\
\hline
\end{tabular}

Os álcalis $\mathrm{K}_{2} \mathrm{O}, \mathrm{MgO}$ e $\mathrm{CaO}$, apareceram em menor concentração comparada a argila, além de uma menor perda ao fogo que se deve ao fato do chamote ser um material queimado a uma temperatura entre $500^{\circ} \mathrm{C}$ a $600^{\circ} \mathrm{C}$, onde já ocorreu a combustão da matéria orgânica, perda das hidroxilas, decomposição dos carbonatos e fusão parcial dos álcalis.

\subsection{OBTENÇÃO DE ALGUMAS PROPRIEDADES TECNOLÓGICAS}

Os resultados obtidos das características cerâmicas nos corpos de prova retangulares são apresentados na Tabela 3. Todos os valores ficaram de acordo com o valor máximo desejado e recomendado por Santos (1992) para argila caulinítica. 
Tabela 3 - Algumas propriedades tecnológicas dos corpos de prova

\begin{tabular}{|c|c|c|c|c|c|}
\hline \multirow{2}{*}{ Composição } & PF (\%) & \multicolumn{1}{c|}{ AA (\%) } & PA (\%) & MEA (g/cm $\left.{ }^{3}\right)$ & $\begin{array}{c}\text { RLQ } \\
(\%)\end{array}$ \\
\hline $0 \%$ & 10,16 & 17,93 & 30,42 & 1,69 & 3,93 \\
\hline $5 \%$ & 11,89 & 20,92 & 33,81 & 1,61 & 3,80 \\
\hline $10 \%$ & 11,02 & 19,62 & 31,81 & 1,62 & 3,68 \\
\hline $15 \%$ & 7,95 & 11,87 & 21,22 & 1,78 & 3,55 \\
\hline $20 \%$ & 10,18 & 18,42 & 30,43 & 1,65 & 3,87 \\
\hline Ref. & - & $\leq 25,00$ & $\leq 35,00$ & 1,50 a 2 & 2 a $17^{*}$ \\
\hline
\end{tabular}

Nota: $\mathrm{PF}=$ Perda de massa ao fogo; $\mathrm{AA}=\mathrm{Absorção} \mathrm{de} \mathrm{água;} \mathrm{PA}=$ Porosidade aparente; $\mathrm{MEA=Massa}$ específica aparente; RLq=Retração linear de queima; Ref= Souza Santos (1975); * valor para argila caulinítica.

Os valores obtidos após os ensaios tecnológicos não seguiram uma sequência com o aumento do chamote, mas com as adições de 5\%,10\% e 15\% de chamote os valores da MEA aumentaram com o acréscimo de chamote. A PA, RLQ, AA e PF diminuíram com o a adição do chamote nas faixas de 5\%, 10\% e 15\%. Esses valores estão relacionados com a conformação do chamote na argila, evitando poros pós queima (perda de água livre), e quanto menores esses valores, menores são as chances de aparecimento de trincas no material. Devido as funcionalidades dos produtos produzidos com esses materiais, a exemplo, panelas, travessas, vasos e outros, a porcentagem mais adequada é a de 15\% devido os resultados obtidos.

\subsection{TESTES NAS PANELAS}

Para a definição dos objetivos específicos, as panelas produzidas com determinadas quantidades de chamote, foram expostas ao fogo, simulando o cozimento de alimentos. As panelas foram ao fogo com água, por 40 minutos cada, o tempo foi determinado devido o tempo médio de cozimento de alimentos, a fim de se observar resultado. Após expostas ao fogo, foram analisadas texturas, cor ou devidas trincas que poderia ocorrem com a presença de calor. As panelas de $0 \%$ (zero porcento) de chamote fraturou-se após aproximadamente 20 minutos a exposição. Confirmando o que é dito pelos próprios artesãos, sobre os utensílios produzidos na localidade. Panelas com adição de chamote 5\%, 10\%, 15\%, e 20\% não sofreram alteração após exposta ao fogo. A partir de $5 \%$ de chamote, o material obteve a característica térmica desejável, no entanto, a adição mais adequada foi a de $15 \%$ devido os resultados das propriedades tecnológicas.

\section{CONCLUSÕES}

Pela aplicação das técnicas de difração de raios X e fluorescência de raios X, foi possível a determinação da composição mineralógica e química da argila do Polo Industrial de Icoaraci. Em todas as amostras os minerais predominantes foram caulinita, quartzo e as micas. Outras fases de menor importância, que também estavam presentes. A amostra de argila considerada, apresentou composições que englobam características de matérias primas atualmente utilizadas nos produtos cerâmicos brasileiros. Com os ensaios tecnológicos, afirmou que a composição de 15\% de chamote seria mais adequada, devido valores de retração linear, perda de massa ao fogo, absorção de água e porosidade aparente serem menores que as demais composições, ou seja, a viabilidade dos materiais com 15\% de chamote é adequada para a produção. Por fim, a utilização de chamote para aumentar a resistência térmica e diminuir a porosidade dos materiais produzidos, tem um grande potencial para ser aplicado. Além disso, o chamote é fácil de ser obtido e não apresenta custo, por ser um material defeituoso descartado. 


\section{REFERÊNCIAS}

[1] Gomes, G. da S. Efeito da incorporação do chamote em argilas para a produção de cerâmicas utilitárias no distrito de Icoaraci, Belém - PA. Trabalho de conclusão de curso. FCET - UFPA, Ananindeua. 66 f. 2018.

[2] Souza, Doracy Moraes de. 0 trabalho dos artesãos ceramistas em Icoaraci, Belém/PA: contribuições aos estudos sobre a dinâmica da Amazônia brasileira. Dissertação, 2010.

[3] Menezes, R.R., Neves, G.A., Ferreira H.C. (2002). 0 estado da arte sobre o uso de resíduos como matériasprimas cerâmicas alternativas. Revista brasileira de Engenharia Agrícola e Ambiental, 6 (2): 303-313.

[4] Vieira, C. M. F.; Souza, E. T. A.; Monteiro, S. N. (2004). Efeito da incorporação de chamote no processamento e microestrutura de cerâmica vermelha. Cerâmica, nº 50, p. 254- 260.

[5] Santos, S. P.; Ciência e tecnologia de argilas, 3ed. Vol. 1. São Paulo: Editora Edgard Blücher Ltda; 1992.

[6] Weber, I. T.; Gomes, J. W.; Mariano, W. A.; Martins H. L. Z.; Longo, E. "Metodologia para cerâmica artística artesanal" - anais do XV Cbecimat - Congresso Brasileiro de Engenharia e Ciências dos materiais, 2002, Natal - RN. 


\section{Capítulo 12}

Obtenção de ésteres etílicos a partir do óleo de tucumã (Astrocaryum Vulgare, Mart.)

\section{Gustavo Henrique Barroso da Silva}

\section{Raissa Sayumy Kataki Fonseca}

\section{Hudson Silva Soares}

\section{João Fernando Alves Costa}

Leiliane do Socorro Sodré de Souza

Anderson Mathias Pereira

Resumo: 0 biodiesel é um combustível ecológico produzido a partir de matérias- primas renováveis. $\mathrm{O}$ objetivo deste estudo é verificar o potencial do óleo proveniente da polpa do tucumã (Astrocaryum vulgare, Mart.) como matéria prima para a produção de biodiesel, e posteriormente determinar as características do biodiesel produzido através de análises de controle de qualidade. Os ensaios experimentais foram feitos com duas condições de razão molar, 1:8 e 1:10, ambas as reações foram realizadas com os mesmos procedimentos e reagentes. 0 catalizador utilizado foi o hidróxido de potássio (KOH) dissolvido em álcool etílico, a temperatura de reação foi a $60^{\circ} \mathrm{C}$, o tempo de reação foi de 60 minutos. A lavagem do biodiesel foi realizada com água destilada a aproximadamente $60^{\circ} \mathrm{C}$ na proporção de $1 / 3$ (água/ésteres) por percolação seguida de três inversões. As análises de qualidade do biocombustível foram realizadas nos ésteres etílicos obtidos após a etapa de lavagem. 0 produto final foi analisado qualitativamente através das análises de viscosidade cinemática e massa específica. 0 valor da massa específica determinada para ambas as razões molares foi de $0,873 \mathrm{~g} / \mathrm{cm}^{3}$, valor dentro das especificações da Agencia Nacional do Petróleo, Gás Natural e Biocombustíveis, ANP. 0 valor da viscosidade do biodiesel proveniente da reação $1: 8$ foi de $6,1 \mathrm{~mm}^{2} / \mathrm{s}$, valor acima do padrão de referência, enquanto a reação 1:10 apresentou uma viscosidade de $5,8 \mathrm{~mm}^{2} / \mathrm{s}$, se enquadrando no valor padrão da ANP. Em ambas as reações foi possível demonstrar a possibilidade de obtenção de ésteres etílicos utilizando o óleo proveniente da polpa do tucumã. 


\section{INTRODUÇÃO}

Atualmente, $80,3 \%$, maior parte de toda a energia consumida no mundo, provém dos combustíveis fósseis, sendo que $57,7 \%$ desse valor é utilizado apenas no setor de transporte (LORA et al, 2012). Essas fontes de energia são limitadas, o que gera uma motivação por buscas de fontes de energias alternativas integrada com o desenvolvimento de tecnologias capazes de utilizar fontes renováveis de energia (FERRARI et al, 2005).

Esses dados levaram ao crescimento da consciência ambiental devido as mudanças climáticas geradas pelos gases do efeito estufa originado da combustão de derivados do petróleo como a gasolina e o diesel, todos esses fatores impulsionaram a busca por combustíveis de fontes renováveis e de menor impacto (FERREIRA, 2009).

O biodiesel é um combustível ecológico produzido a partir de matérias-primas renováveis provenientes da biomassa, o que diminui a utilização do petróleo, mediante processo produtivo que consome óleos vegetais e gorduras animais como recurso principal. Trata-se de um combustível de uso simplificado, não tóxico e essencialmente livre de compostos sulfurados e aromáticos. Embora não contenha petróleo, pode ser adicionado a ele formando uma mistura em diversas proporções, sendo utilizado em motores de ignição à compressão (ciclo diesel), dispensando, conforme o teor de mistura, modificações ou adaptações dispendiosas (LORA et al, 2012).

No Amazonas, há uma grande diversidade de matérias-primas nativas que possibilita a produção de biocombustíveis, entre as quais incluem-se o tucumã (Astrocaryum vulgare, Mart.). Esta fruta é uma das várias oleaginosas amazônicas que satisfazem os critérios fundamentais para o uso adequado e sustentável na produção de biodiesel na Amazônia (FIGLIUOLO et al, 2007). Referente ao tema biocombustível e sua importância ecologia e socioeconômica, foi proposto a utilização do óleo de tucumã para a obtenção de ésteres etílicos.

\section{MATERIAL E MÉTODOS}

0 trabalho foi desenvolvido no Laboratório de Processos de Separação (LABPROS) vinculado ao curso de Engenharia de Alimentos da Faculdade de Ciências Agrárias (FCA) na Universidade Federal do Amazonas (UFAM).

\subsection{MATÉRIA PRIMA}

A polpa de tucumã foi adquirida de um comerciante local da região norte de Manaus. No laboratório, a matéria prima foi pesada em uma balança (Weblaborsp, modelo L1002i). Do total de matéria prima inicial, $300 \mathrm{~g}$ foram retirados para posteriores análises, o restante foi submetido a secagem em uma estufa com recirculação de ar (Nova Ética) a $50^{\circ} \mathrm{C}$ por 24 horas.

\subsection{ANÁLISE CENTESIMAL DA POLPA DE TUCUMÃ}

Foram realizadas as análises de umidade, cinzas e lipídeos no LABPROS, todas as análises foram realizadas em triplicatas e seguiram as metodologias oficiais da Association Of Official Analytical Chemists (A.O.A.C).

\subsection{EXTRAÇÃO DO ÓLEO}

A polpa do tucumã foi distribuída em bandejas de alumínio e submetida a desidratação numa estufa, por cerca de 24 horas, à temperatura de $50{ }^{\circ} \mathrm{C} \pm 1{ }^{\circ} \mathrm{C}$, para que ocorresse a redução do teor de umidade, necessário para aumentar o rendimento de extração na prensagem. A extração do óleo da polpa foi feita em uma prensa mecânica contínua, tipo "expeller", (SCOTT TECH, ERT 60 II). 0 óleo extraído apresentou resíduos da torta e, portanto, foi filtrado com o auxílio de uma bomba de vácuo (Lab 1000, LM300) para eliminação de partículas sólidas.

\subsection{CARACTERIZAÇÃO FÍSICO-QUÍMICA DO ÓLEO}

A caracterização físico-química do óleo de tucumã foi realizada através das análises de índice de acidez, índice de saponificação, massa específica, viscosidade e índice de refração. As análises seguiram as 
determinações da American Oil Chemists Society (A.O.C.S.) e A.O.A.C.

\subsection{PRÉ-TRATAMENTO DO ÓLEO PARA A TRANSESTERIFICAÇÃO}

O óleo de tucumã apresentou uma alta acidez, portanto foi necessário realizar um pré-tratamento que consistiu de uma neutralização. A neutralização foi realizada em escala de laboratório usando-se $400 \mathrm{~g}$ de óleo e uma solução de hidróxido de sódio $(\mathrm{NaOH})$ a $15 \%$ adicionada ao óleo por gotejamento por cerca de 5 minutos à temperatura ambiente e agitação constante em um Jar Test Microprocessado (Quimis, Q305M). Posteriormente, a solução foi depositada em um funil de decantação para a separação das fases (óleo e sabão) em uma estufa à 40 ํ․ Após a separação das fases, o sabão gerado foi descartado e o óleo neutralizado foi reservado para ser submetido a uma nova análise de acidez.

\subsection{EXPERIMENTOS DE TRANSESTERIFICAÇÃO}

Os ensaios experimentais foram feitos com duas condições de razão molar, 1:8 e 1:10 (óleo:álcool), ambas as reações foram realizadas seguindo os mesmos procedimentos e reagentes. Em um reator foi adicionado $150 \mathrm{~g}$ de óleo, submetido ao aquecimento e agitação magnética, as reações foram realizadas em um agitador magnético com aquecimento (Fisatom, 752A).

0 catalisador hidróxido de potássio $(\mathrm{KOH})$ foi dissolvido em álcool etílico na concentração $95 \%$ e adicionado ao óleo quando este atingiu a temperatura de $60 \stackrel{\circ}{\circ}$, a mistura reacional permaneceu por aproximadamente 60 minutos a $60{ }^{\circ} \mathrm{C}$ sob agitação constante. Para cessar a reação de transesterificação foi adicionado estequiometricamente ácido clorídrico na solução, após a adição do ácido a solução permaneceu sendo homogeneizada por aproximadamente 5 minutos. Posteriormente, a mistura reacional foi transferida para um funil de decantação onde ocorreu a separação das fases (ésteres brutos, glicerol e sal).

A fase inferior, abundante em glicerol, sal e catalisador, foi removida restando apenas a fase superior, rica em ésteres etílicos brutos e resíduos de álcool que não reagiram na reação de transesterificação. 0 excesso de álcool foi separado por evaporação simples através de um evaporador rotativo (TECNAL, TE-211) e por fim levado a um funil de decantação para proceder com a retirada de impurezas ainda existentes através de lavagem com água destilada a aproximadamente $60^{\circ} \mathrm{C}$ na proporção de $1 / 3$ (água/ésteres) por percolação seguida de três inversões. 0 produto final foi depositado em recipiente de vidro vedado e reservado, para posterior análises da qualidade do biodiesel.

\subsection{ANÁLISES DA QUALIDADE DO BIODIESEL}

As análises de qualidade do biodiesel foram realizadas nos ésteres obtidos após a etapa de lavagem. 0 produto final da reação de transesterificação foi analisado qualitativamente através das análises de viscosidade cinemática, realizada seguindo a determinação citada no item 2.4., e massa específica, medida através de densímetro digital.

\section{RESULTADOS E DISCUSSÃO}

Nesta seção, serão apresentados e discutidos os resultados obtidos na caracterização da polpa e do óleo de tucumã, assim como os resultados das análises de qualidade do biodiesel.

\subsection{CARACTERÍSTICAS FÍSICO-QUÍMICAS DA POLPA}

Os resultados de umidade, cinzas e lipídeos da polpa do tucumã estão apresentados através da média aritmética das triplicatas, seguidas de desvio padrão. Os dados são mostrados na Tabela 1.

Tabela 1 - Valores percentuais de umidade, cinzas e lipídeos do tucumã

\begin{tabular}{|c|c|c|c|c|}
\hline Amostra & \multicolumn{2}{|c|}{ Umidade \%(b.u.) } & $\begin{array}{l}\text { Cinzas } \\
\% \text { (b.u.) }\end{array}$ & Lipídeos \%(b.s.) \\
\hline Tucumã & 59,39 目 0,67 & & & 41,25 目 0,61 \\
\hline Literatura* & 52,47 ? 0,96 & & & 30,40 ? 1,16 \\
\hline
\end{tabular}


Observa-se que a polpa de tucumã apresenta um alto valor de umidade, sendo necessário retirar a umidade para a realização da extração do óleo, este valor determinado é coerente ao resultado encontrado por Silva (2008) para o mesmo fruto. 0 valor percentual de cinzas de 1,51 não apresenta diferença significativa do valor encontrado na literatura. 0 teor de lipídeos de 41,25 \% é superior ao valor encontrado por Silva, no entanto, o valor obtido na análise está próximo ao citado por Vasconcelos (2010) de aproximadamente $39,58 \%$.

\subsection{CARACTERIZAÇÃO FÍSICO-QUÍMICA DO ÓLEO}

A Tabela 2 mostra os valores obtidos da caracterização do óleo bruto e óleo refinado, para as análises de índice de acidez, índice de saponificação, viscosidade e densidade.

Tabela 2 - Características físico-químicas do óleo do tucumã

\begin{tabular}{|c|c|c|c|c|c|}
\hline & $\begin{array}{l}\text { Índice de acidez } \\
\text { (mg KOH/g) }\end{array}$ & $\begin{array}{c}\text { Índice de } \\
\text { saponificação (mg } \\
\mathrm{KOH} / \mathrm{g})\end{array}$ & $\begin{array}{l}\text { Viscosidade à } \\
40^{\circ} \mathrm{C}(\mathrm{cSt})\end{array}$ & $\begin{array}{c}\text { Densidade à } 20^{\circ} \mathrm{C} \\
\left(\mathrm{g} / \mathrm{cm}^{3}\right)\end{array}$ & $\begin{array}{l}\text { Índice de } \\
\text { refração }\end{array}$ \\
\hline Óleo bruto & 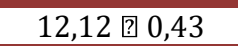 & 185,3 우 0,98 & - & - & - \\
\hline Óleorefinado & 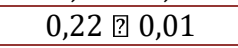 & 181,05 ? 0,98 & 43,1 目 0,56 & 1,17 ? 0,01 & 1,47 \\
\hline
\end{tabular}

O óleo obtido após a prensagem apresentou um índice de acidez elevado, possivelmente decorrido do longo período de armazenamento da matéria prima. Um excesso de ácidos graxos livres resulta em uma reação de saponificação, quando se usa uma base como agente catalisador, concorrendo com a reação de transesterificação. Em vista disso, a neutralização do óleo foi realizada de acordo como descrito no item 2.5. A neutralização resultou em um óleo com um novo índice de acidez de 0,22 mg de $\mathrm{KOH} / \mathrm{g}$, valor considerado adequado para a realização da reação de transesterificação.

Vasconcelos (2010) determinou um índice de saponificação de aproximadamente 193,61 mg de KOH/g para o óleo da polpa de tucumã do Amazonas extraído por prensagem hidráulica, esse valor é superior ao determinado pela análise feita em laboratório que resultou em um valor de 181,05 mg de KOH/g. 0 índice de saponificação do óleo de tucumã bruto encontrado neste estudo foi de aproximadamente de 185,3 mg de $\mathrm{KOH} / g$. $\mathrm{O}$ elevado índice de saponificação indica que óleo proveniente da polpa de tucumã é composto por ácidos graxos de cadeia curta, este parâmetro está relacionado com a comestibilidade do óleo. Cada tipo de óleo vegetal apresenta um valor definido que corresponde a sua faixa característica, portanto, seja qual for a alteração no valor deste parâmetro pode representar misturas com outros óleos.

O óleo de tucumã apresentou uma viscosidade a $40^{\circ} \mathrm{C}$ de $43,1 \mathrm{cSt}$, valor menor do que o encontrado por Silva (2008) de 49,7 cSt. Uma alta viscosidade impossibilita a utilização diretamente do óleo como combustível do ciclo diesel por ocasionar a diminuição da durabilidade do motor e a formação de depósitos de carbono nos bicos injetores.

Com relação a massa específica, cujo valor médio obtido foi de $1,17 \mathrm{~g} / \mathrm{cm}^{3}$, dado superior ao valor citado por Silva (2008), que reporta o seguinte valor de massa específica equivalente a $0,9 \mathrm{~g} / \mathrm{cm}^{3}$. 0 valor superior ao encontrado na literatura é devido ao longo período de armazenamento da polpa de tucumã que sofreu a ação da luz e do calor, resultando em um maior número de ácidos graxos livres e matérias presentes em uma unidade de volume do óleo.

O índice de refração é diretamente proporcional ao índice de insaturações na cadeia carbônica. Portanto, é bastante utilizado como padrão de identidade e qualidade dos óleos vegetais. Após o procedimento para se determinar o índice de refração do óleo extraído da polpa

de tucumã obteve-se o valor de 1,470. Valor igual ao encontrado por Vasconcelos (2010).

\subsection{ANÁLISES DA QUALIDADE DO BIODIESEL}

As análises realizadas no biodiesel de tucumã foram viscosidade e densidade e estão apresentadas na Tabela 3. 
Tabela 3 - Análises do biodiesel de tucumã

\begin{tabular}{|c|c|c|}
\hline Amostra & $\begin{array}{c}\text { Massa } \\
\text { Específica }\left(\mathrm{g} / \mathrm{cm}^{3}\right)\end{array}$ & $\begin{array}{c}\text { Viscosidade } \\
\text { Cinemática }\left(\mathrm{mm}^{2} / \mathrm{s}\right)\end{array}$ \\
\hline $1: 8$ & 0,873 & 6,1 ? 0,1 \\
\hline $1: 10$ & 0,873 & 5,8 ? 0,2 \\
\hline Literatura* & 0,856 & 5,6 \\
\hline \multicolumn{3}{|c|}{ *dados de Silva, 2008} \\
\hline
\end{tabular}

0 valor da massa específica determinada para ambas as amostras, tanto para razão molar 1:8 quanto para razão molar 1:10, de biodiesel encontram-se dentro das especificações da Agencia Nacional do Petróleo, Gás Natural e Biocombustíveis, ANP.

A ANP determina o intervalo de 3,0 a $6,0 \mathrm{~mm}^{2} / \mathrm{s}$ como padrão de referência para a viscosidade do biodiesel. 0 valor da viscosidade de ambas reações apresentaram-se dentro das margens aceitáveis da especificação da ANP. A viscosidade elevada pode ser justificada pela degradação do óleo e pela não reação total dos glicerídeos que compõem o óleo. Alves (2010) determinou uma viscosidade de $6,1 \mathrm{~mm}^{2} / \mathrm{s} \mathrm{no}$ biodiesel produzido a partir do óleo utilizado em fritura, e justificou o aumento da viscosidade pela presença de ácidos graxos que não reagiram durante o processo reacional. Uma melhor viscosidade pode ser obtida submetendo a amostra a centrifugação ou a filtração a vácuo várias vezes, resultando em produto sem impurezas, garantindo assim uma viscosidade no intervalo exigido pela ANP.

\section{CONCLUSÃO}

Analisando os resultados da caracterização físico-química do óleo bruto da polpa de tucumã, este apresentou um índice de acidez elevado, impossibilitando sua aplicação como matéria-prima na reação de transesterificação. Contudo foi possível demonstrar a possibilidade de obtenção de ésteres etílicos utilizando o óleo da polpa de tucumã, após este passar por um processo de neutralização, garantindo um índice de acidez aceitável. Ainda são necessários estudos para melhorar a eficiência da reação de transesterificação para os dois tipos de razão molar, 1:8 e 1:10, especialmente em relação ao tempo e temperatura de reação, para tornar rentável o emprego desse óleo na produção de ésteres etílicos em maior escala.

\section{REFERÊNCIAS}

[1] American Oil Chemists Society. Official methods and recommended practices of the Aocs. 5. ed. Champaigh, Illinois, Usa: American Oil Chemists' Society, c2004. 1 v.

[2] ANP - Agencia Nacional do Petróleo, Gás Natural e Biocombustíveis. Disponível em:<http://www.anp.gov.br/biocombustiveis/biodiesel.asp>. Acesso em: 07 de fevereiro de2019.

[3] Association of Official Analytical Chemists. Official methods of analysis of Aoac International. 18. ed. Gaithersburg, Maryland: Aoac Internacional, 2006. 1 v. ISBN 0935584773.

[4] Codex Alimentarius - International Food Standars. Disponível em:<http://www.fao.org/fao-whocodexalimentarius/codex-texts/list-standards/en/> Acesso em: 15 de fevereiro de 2019.

[5] Ferrari, R. A.; Oliveira, V. DA S.; Scabio, A. Biodiesel de Soja: taxa de conversão em ésteres etílicos, caracterização físico-química e consumo em gerador de energia. Química Nova. v. 28, n. 1, p. 19-23, 2005.

[6] Figliuolo, R.; Silva, J.D.; Costa, M.S.T.A. Produção de Biodiesel na Cadeia Produtiva e Sustentável do Tucumã do Amazonas (Astrocaryum aculeatum G.F.W. Mayer) (Arecácea, palmeira). In: Congresso da Rede Brasileira de Tecnologia de Biodiesel, 2,2007, Brasília/DF. Anais..., p. 73-73.

[7] Lôbo, I.P.; Ferreira, S.L.C. Biodiesel: Parâmetros de qualidade e métodos analíticos. Química Nova, São Paulo, v.32, n.6, p.1596-1608, julho. 2009.

[8] Lora, E. E. S.; Venturini, O. J., Biocombustíveis. V.1, Interciência, Rio de Janeiro, 2012.

[9] Silva, S. N. D. Processo de transesterificação do óleo da polpa de tucumã (Astrocaryum Vulgare) com etanol para produção de biodiesel. 61 p. Dissertação (Mestrado em Engenharia Química). Universidade Federal do Pará. Belém, 2008.

[10] Vasconcelos, B. E.C. Avaliação das características físicas, químicas e nutricionais dos óleos do tucumã (Astrocaryum Aculeatum e Astrocaryum Vulgare) obtidos com co2 pressurizado. 112 p. Dissertação (Mestrado em Ciência e Tecnologia de Alimentos). Universidade Federal do Pará. Belém, 2010. 


\section{Capítulo 13}

\section{Pem type fuel cell polarization curve experimental determination}

\section{Roque Machado de Senna \\ Thais Santos \\ Henrique de Senna Mota \\ Marcelo Linardi}

Abstract: The electric energy generation presents itself as a great mankind challenge due to its enormous potential pollutant, especially when coming from fossil fuels. In the world, in 2013, as shown in BEN 2016, only 13.5\% of the energy matrix was renewable fuels made up being in Brazil 41.2\%. Based on these statistics it can be affirmed that the energy production in Brazil is still fossil fuels predominant. One of the alternatives that deserves special mention is the fuel cells (CAC) technology, since they are sustainable and non-polluting devices that oxidize electrochemically the fuel, usually hydrogen, generating electric energy and heat. This work is aim to show the procedures to test a unitary CAC of solid electrolyte ETEK_HP, a Náfion (PTFE) membrane with a $115 \mu \mathrm{m}$ thickness composed and the electrode being a platinum catalyst with a $0,4 \mathrm{mg} / \mathrm{cm}^{2}$ load at the anode and $0.6 \mathrm{mg} / \mathrm{cm}^{2}$ at the cathode, supported on carbon. The optimum CAC operating point by the MEA efficiency was $433 \mathrm{mV} @ 1,120 \mathrm{~mA}$, with linear characteristic and it is not significantly subject to the activation and mass transfer phenomena. It is noted that between $365 \mathrm{mV}$ and $558 \mathrm{mV}$ the density was above $0.45 \mathrm{~W}$ $/ \mathrm{cm}^{2}$ and consequently the CAC power above $11 \mathrm{~W}$. The oxygen and hydrogen consumption were more efficient above $800 \mathrm{mV}$.

Keywords: Polarization Curve. PEM Fuel Cell Tests. Fuel Cell unit. Electrochemical Energy Generation. 


\section{INTRODUCTION}

Despite enormous social and economic relevance, activities related to the collection, distribution and energy use have enormous impacts on the environment, releasing substances into the atmosphere, water sources and soil, compromising the entire terrestrial ecosystem health and survival. The energy systems various stages, such as extractive activities, their conversion, distribution and use, are closely related to each other, and to the all mankind development. There is a growing need to find solutions to the production chain negative effects, distribution and energy use processes in order to minimize social, environmental and economic losses. Population growth, especially in developing countries, and the increasing energy resources per inhabitant consumption, have been raising concerns regarding the human activities' sustainability (ALDABÓ, 2004; BONIFÁCIO, 2011; FUKUROZAKI, 2006).

Fuel cells suggested in 1839, due to electrochemical research work developed by William Grove. However, the first practical fuel cell developed by Francis Bacon occurred in England in 1932. The fuel cell module that was the research subject was a $5 \mathrm{~kW}_{\mathrm{e}}$ (kilowatt electric) unit powered by hydrogen and oxygen gases, supported on an alkaline electrolyte (COOK, B., 2002).

The objective is to show, besides the results, the procedures for the fuel cell unit test, consisting of a surface area $25 \mathrm{~cm}^{2}$ solid electrolyte, and $7 \mathrm{~W} @ 700 \mathrm{mV}$ at rated power and operating voltage. The test steps are shown in the systemic approach form involving various technological aspects, in order to contribute to a greater, the procedures and methods dissemination of this technology quality verification.

\section{PEMFC CELL FUNCTIONING BASIC PRINCIPLE}

The fuel cell is, in short, an electrochemical energy transformer, oxidizes hydrogen at the anode, negative pole, and reduces cathode oxygen at the positive pole by gaseous diffusion electrodes, as shown in figure (1).

Figure 1: PEM Single Fuel Cell Simplified Diagram

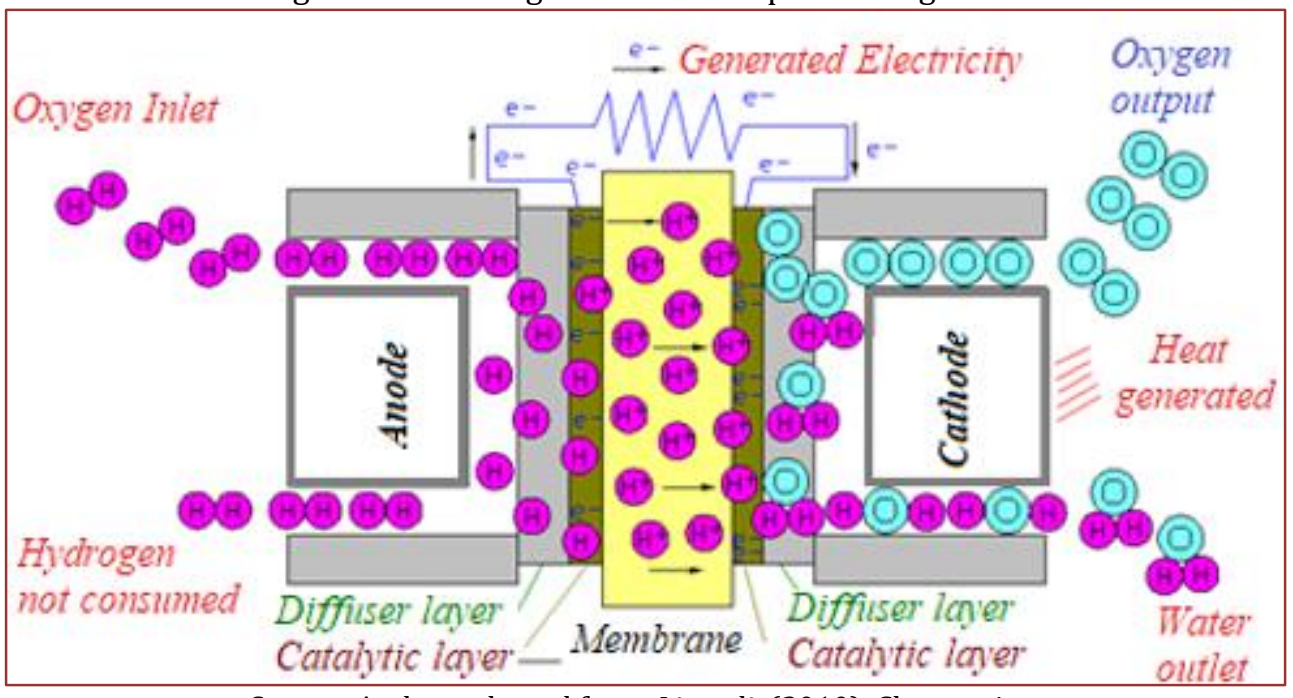

Source: Author, adapted from: Linardi, (2010), Chapter 4. 
In a fuel cell type (PEM), two half-cell reactions occur simultaneously, one oxidation reaction, electron loss at the anode, and one electron gain reduction reaction at the cathode. These two reactions make up the fuel cell oxidation-reduction reactions responsible for the water formation from the gaseous elements hydrogen, oxygen and heat, as well as the electric energy release in the electron flow form through the electrical circuit external to the polymeric ion exchanger membrane. The chemical equations that occur in a PEM type cell are shown in (1), (2), (3):

$$
\begin{aligned}
& \text { Anode reaction: } \\
& \text { Cathodic reaction: } \\
& \text { General reaction: }
\end{aligned}
$$

At the anode, hydrogen molecules come into contact with the platinum catalyst on the gas diffusion electrode surface. Hydrogen molecules break apart by adhering to the platinum surface separately through H-Pt weak polar bonds. When the hydrogen molecule breaks down the reaction occurs. Each hydrogen atom releases its electrons through an external electrical circuit to the charge that deviates from the polymeric membrane, which is an electrical insulator; where the diverted electrons find the oxygen ion in the cathode. In turn, the hydrogen ions cross the water-permeable membrane associated with the proton ions in the $\mathrm{H}_{3} \mathrm{O}^{+}$form, reaching the cathode, leaving the platinum catalyst free to promote the new hydrogen molecules breakdown (CUNHA, EF; 2009).

At the cathode oxygen molecules come into contact with a platinum catalyst on the gas diffusion electrode surface. Oxygen molecules adhere separately to the platinum electrode surface forming 0-Pt weak polar bonds, this creates the necessary conditions for the reduction reaction to occur. Each oxygen atom then leaves the platinum catalyst, combining with two electrons and two hydrogen ions to form a water molecule. Reduction reactions are now completed. The platinum catalyst in the cathode gas diffusion electrode is now free to weaken the new oxygen molecules bonds (LINARDI, 2010).

\subsection{GAS DIFFUSION ELECTRODE}

As shown in figure (1), gas diffusion electrodes are the elements that associated with each face of (PTFE) give the physical configuration to (MEA). Its structure is divided into catalytic layer and diffuser layer, and the catalytic layer aims to make the activity of platinum electrocatalysts more efficient, which are associated with other chemical elements, such as metals and oxides, in the form of alloys, in order to accelerate reactions as well as reduce production costs. As the diffuser layer contains active carbon particles in its structure, and due to its large porosity, extremely close contact with gas, liquid and PTFE occurs, and significantly facilitates the occurrence of reactions. The diffuser layer is formed of a thin carbon fabric thermally pressed over the catalytic layer (COOK, B., 2002).

\subsection{WATER REACTION ENERGY}

This exothermic reaction of water formation from oxygen and hydrogen gases has an enthalpy of the order of $-285.8 \mathrm{~kJ}$ of energy per mol of water formed. The energy available for work is reduced as a function of temperature. For example, at $25^{\circ} \mathrm{C}$, at a pressure atmosphere, the free energy available for work is around $-237.1 \mathrm{~kJ} / \mathrm{mol}$. This energy comes in the form of electron flow (electric current) and heat (FELTRE, R., 2004).).

\subsection{PROTON EXCHANGER POLYMER ELECTROLYTIC MEMBRANE}

The membrane material used in a PEM-type cell is a laminar-shaped polymer with thicknesses typically ranging from 50 to $175 \mu \mathrm{m}$ (micrometers). The catalytic electrode layer is applied to the membrane both sides (PTFE) and then cut to the desired dimensions (CUNHA, E. F.; 2009).

Náfion ${ }^{\circledR}$, is the most used material. Developed in the 1970s by Dupont, Náfion ${ }^{\circledR}$ polytetrafluoroethylene consists (PTFE) chain, commonly known as Teflon, which forms the PEM-type membrane base structure. Linked to the chain end are the sulfonic acid groups $\left(\mathrm{HSO}_{3}\right)$, and the chemical chain side in which the 
sulfonic group is present is hygroscopic and is responsible for conducting the ions and water inside the membrane. On the other hand, it has the opposite behavior in relation to water (LINARDI, 2010).

For the membrane to efficiently conduct ions the sulfonic group side structure must absorb water reasonable amounts. With this region properly hydrated, the hydrogen ion is able to move freely within the membrane, fulfilling its expected role. This membrane is chemically resistant and is still very successful today due to its relative longevity compared to other membranes that occurred prior to its discovery. The Náfion ${ }^{\circledR}$ membrane advent came about as a chlorine electrolysis result with caustic soda work (LINARDI, 2010).

\subsection{ELECTRICAL BEHAVIOR AND EFFICIENCY}

When transforming chemical energy into electrical energy, an optimally behaving fuel cell should deliver the $1.23 \mathrm{~V}$ potential, but in fact delivers approximately $1.0 \mathrm{~V}$ when subjected to the atmosphere pressure at a $25{ }^{\circ} \mathrm{C}$ temperature. The $1.23 \mathrm{~V}$ value is not reached. The causes one is due to the heat released during the reactions, as well as its operating temperature around $80^{\circ} \mathrm{C}$. Also contributing to this potential fall are other factors listed in (2.4.1), (2.4.2) which are referred to as primary losses (WENDT, H.; LINARDI, M.; ARICÓ, E. 2002).

\subsubsection{ACTIVATION LOSSES}

Activation losses are those due to initial reaction conditions and are significantly influenced by the catalyst action. The more efficient the catalyst the lower the energy required to process the reaction, and in this paper, platinum offers excellent results, however the cost incurred in its unique application is high. Currently, new techniques are available where platinum is associated with metals and oxides, which has led to significant cost reductions and increased efficiency (SPINACÉ, E.V., OLIVEIRA NETO, A.; LINARDI, 2004).

These questions have fostered countless research on materials that are better suited to the catalytic process and are competitively priced. An important factor in limiting the power density delivered by the cell action is the speed at which reactions occur within it. The cathode reaction (oxygen reduction) is about 100 times smaller than the anode reaction (Brian Cook, 2002). From this finding it can be concluded that the technological bottleneck is located and that is where attention should be devoted.

Fuel entrainment within the electrolyte and internal electric current are also important factors in increasing the drop in electrical potential and yield losses. These factors occur even when considering the high electronic the electrolyte resistance. (WENDT, H.; LINARDI, M.; ARICÓ, E. 2002).

\subsubsection{LOSSES DUE TO GAS CONCENTRATION CONTENT AND MASS TRANSPORT}

They are the concentration reduction resultant of hydrogen gas and oxygen in the electrodes. This can be observed in the following situation: the operating logic is that after the reaction new gases must reach the electrodes and consequently the catalyst layer to make the process continuous. At the cathode, as the process begins, water formation begins, which accelerates to high current densities, causing restrictions on oxygen access, which reduces yield. The fuel cell action control system must act immediately, maintaining the oxygen supply (LINARDI, 2010).

\section{METHODOLOGY}

\subsection{THE IPEN / USP FUEL CELL LABORATORY}

The oxygen, hydrogen and nitrogen purge gases to serve the laboratory are conducted via piping. Just outside the reservoirs are gas flow and pressure gauges. Upon arrival at the laboratory, the gases are again measured, in the hand-operated mass flow meters to meet the experiments. Just outside the mass flow meter, the gases undergo a process of humidifying, heating and raising the vapor pressure. In the humidifier (anode) the temperature must be maintained manually at $85^{\circ} \mathrm{C}$ and in the cell at $70^{\circ} \mathrm{C}$. The fuel cell should be operated for a period of one to two hours to stabilize operating conditions to obtain a better test accuracy and thus to avoid gross fluctuations in the test results (CUNHA, E. F. 2009). 


\subsection{IPEN / USP EXPERIMENT DESCRIPTION}

Start the experiment after the laboratory is ready for the test, check the adjustment that will be given to the dynamic load, set the regulator to the beginning, so that at the end reaches the value near 38A. Preliminary procedures are considered to have been previously performed such as anode nitrogen purging routines, as well as the fuel cell connection to be tested for an one interval to two hours for the test temperature stabilization (LINARDI, M.; 2010).

The dynamic load to adjust from the $38 \mathrm{~A}$ cell is initially adjusted in the upper load capacity range and progressively every two amperes of current reduction, with a two minute wait, at a cell temperature maintained at $70^{\circ} \mathrm{C}$, pressure atmospheric and gas flow according to the reagent flow chart, as the current a function, plus $50 \%$ stoichiometric excess.

The experiment is concluded when the dynamic load adjustment reaches zero electric current. For the current values range between two and zero, for the cell activation region better definition, measurements should be made from two hundred to two hundred milliamperes.

The dynamic load has three adjustment ranges, the náfion membrane has the115 $\mu$ m thickness, the platinum catalyst is type ETEK_HP, has the $0.4 \mathrm{mg} / \mathrm{cm}^{2}$ platinum load at the anode and $0.6 \mathrm{mg} / \mathrm{cm}^{2}$ at the cathode. In the mass flow meter hydrogen channel three is supplied and in channel four, oxygen (CUNHA, E. F.; 2009).

In addition to what has been described so far, the data is acquired on a dedicated electronic board or manually completed by filling out the voltage values in $\mathrm{mV}$, delivered by cell to the dynamic load, and the corresponding electrical current after each current setting provided in the dynamic load dial (LINARDI, M; 2010).

\section{RESULTS AND DISCUSSION}

The measured values are checked and processed. The experiment result is shown in figure (2) and (3) respectively called Polarization Curve and Maximum Fuel Cell Power Curve. Important information is obtained from these two Curves, resulting from the tests:

Figure 2: Polarization Test of a PEM Single Fuel Cell

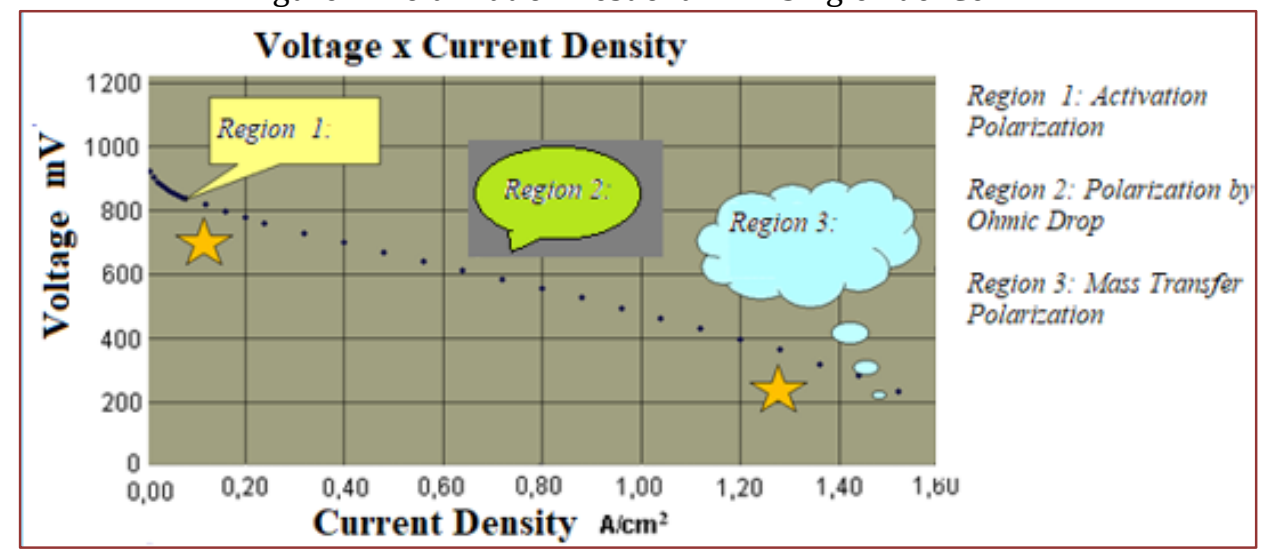

Source: Author, tested at IPEN / USP laboratory.

\section{Look at figure (2)}

I - Activation polarization section typical in Region 1 : it is close to the $838 \mathrm{mV}$ potential, and the demanded current in the range from zero to $80 \mathrm{~mA} / \mathrm{cm}^{2}$;

II - Ohmic polarization section typical in Region 2: it is located in the $838 \mathrm{mV}$ to $365 \mathrm{mV}$ range, and demanded current in the $80 \mathrm{~mA} / \mathrm{cm}^{2}-1280 \mathrm{~mA} / \mathrm{cm}^{2}$ range; 
III - Mass transfer polarization typical in Region 3: it is located in the $365 \mathrm{mV}$ to $200 \mathrm{mV}$ range, and demanded current in the $1280 \mathrm{~mA} / \mathrm{cm}^{2}$ to $1500 \mathrm{~mA} / \mathrm{cm}^{2}$ range;

Figure 3: Maximum Power Density: PEM Single Fuel Cell

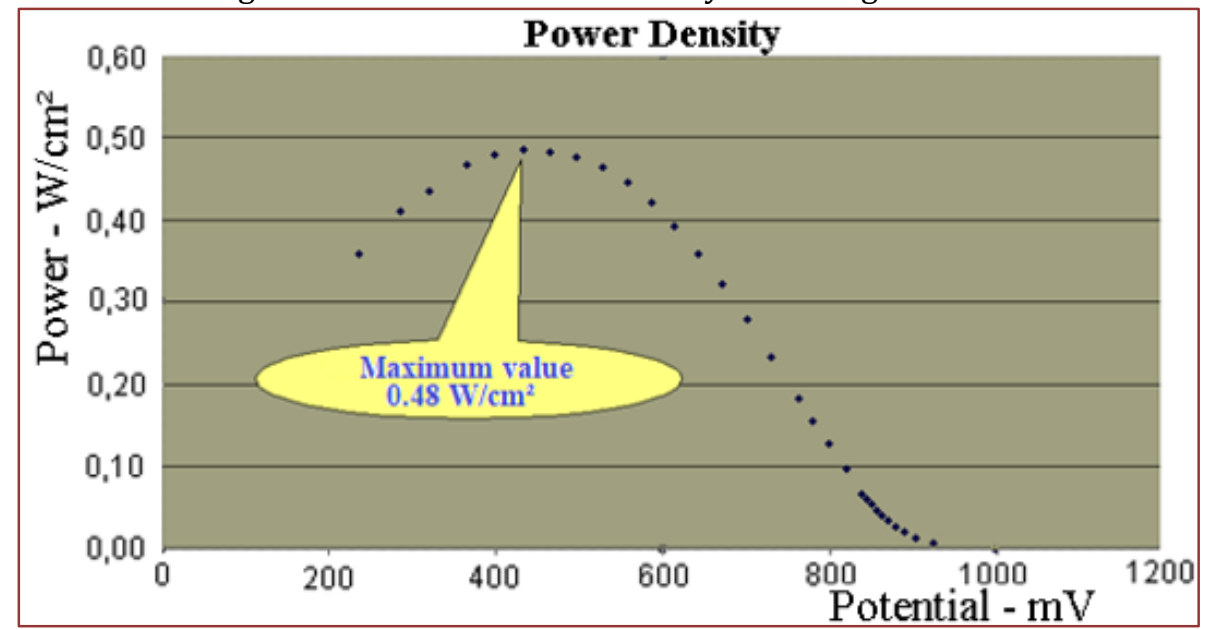

Source: Author, tested at IPEN / USP laboratory.

\section{Look at figure (3)}

IV - The maximum power density: $0.48 \mathrm{~W} / \mathrm{cm}^{2}$.

Durability, reliability, economic feasibility study, operating characteristics for load fluctuation situations, among others, were not evaluated.

\section{CONCLUSIONS}

It is concluded, when evaluating the test results that the fuel cell optimum operation point in the efficiency view MEA use is located at $433 \mathrm{mV}$ and current density $1120 \mathrm{~mA}$. This point is located in the region governed by the ohmic losses predominant effect which is linear and is not subject significantly to the activation and mass transfer phenomena. In order to define an operation point, other considerations can be made, such as: the membrane useful life, a satisfactory relation between acquisition cost and the energy supplied amount among other possibilities. Other tests may be necessary for a better decision, such as: durability, reliability, economical feasibility study, load fluctuation situations operating characteristics, among others.

Note that in the voltage range between $365 \mathrm{mV}$ and $558 \mathrm{mV}$ the power density is at a high level and above $0.45 \mathrm{~W} / \mathrm{cm}^{2}$ and consequently the total power delivered by the cell is above $11 \mathrm{~W}$, it is configured an interest in terms region of the best MEA yield per area. When analyzing the operating point from the oxygen and hydrogen consumption view point concludes the best operating point is located above 800 $\mathrm{mV}$.

\section{REFERENCES}

[1] Aldabó, R. Célula Combustível a Hidrogênio - Fonte de Energia da Nova Era. São Paulo: Artiber, 2004. 182p

[2] Ben - Balanço Energético Nacional 2016. Rio de Janeiro. Brasil.

[3] Cook, Brian. Introduction to fuel Cells and hydrogen technology. Engineering Science and Education Journal, published by Elsevier. V. 11, issue 6. Dec. 2002. P. 205-216.

[4] Cunha, E. F. Avaliação e Aplicação de Tecnologias de Células a Combustível tipo PEMFC Desenvolvidas no IPEN em um Módulo de 500We de Potência Nominal. 2009. 135p. Thesis (Doctorate in Science - Nuclear Technology), Energy and Nuclear Research Institute, IPEN / USP, São Paulo, Brazil.

[5] Feltre, R. Físico Química. published by Ed. Moderna. 6. Ed. 2004, 417p. São Paulo, Brasil. 
[6] Linardi, M.; Introdução à Ciência e Tecnologia de Células a Combustível. São Paulo-SP, Brasil: Altiber Editora, 1ª edição, 2010. 152p. ISBN: 978-85-88098-52-7

[7] Spinacé, E.V., Oliveira Neto, A.; Linardi, M. Electro-oxidation of methanol and ethanol using PtRu/C electro catalysts prepared by spontaneous deposition of platinum on carbon-supported ruthenium nanoparticles. Journal of Power Sources, v. 129, issue 2, p. 121-126, 22 Apr. 2004

[8] Wendt, H.; Linardi, M.; Aricó, E. Células a Combustível de Baixa Potência para Aplicações Estacionárias, Química. Nova, São Paulo, SP. Vol. 25, No. 3, p. 470-476, 2002. 


\section{Capítulo 14}

Tratamento do efluente gerado na produção do biodiesel por meio da adsorção com pó de alto-forno e pó de minério

\section{Ivan Pedro Arêdes Sousa Xavier}

Lorena Ferreira Alves

Jamyla Soares Anício Oliveira Félix

Francine Duarte Castro

Resumo: 0 presente trabalho teve como objetivo tratar o efluente gerado na produção do biodiesel, utilizando pó de alto forno e pó de minério, por meio do método de adsorção. Os resíduos foram classificados quanto à granulometria, observando-se maior fração de partículas com diâmetro inferior a 0,075 e superior a 2,75 mm. Após essa etapa, quantificou-se a DQO do efluente estudado, que apresentou valor de 304111,11 mg de 02/L. A turbidez (29000 FAU) e o pH $(9,3)$ do efluente também se mostraram altos. Nas etapas posteriores, para se avaliar as condições ótimas de adsorção, foram obtidas as condições mais favoráveis de tratamento para o pH (entre 2 e 3); concentração de resíduo ( $1 \mathrm{~g} / \mathrm{L}$ ); e granulometria do resíduo (partículas com diâmetro inferior a 0,075 mm). A partir do estudo cinético, observou-se que, a remoção da DQO nas primeiras horas foi aproximadamente 30\%, seguindo um modelo de pseudoprimeira ordem, enquanto no equilíbrio ( 24 horas) foi cerca de $80 \%$, para ambos os resíduos. 


\section{INTRODUÇÃO}

$\mathrm{Na}$ busca por novas fontes de energia, muitas pesquisas têm sido desenvolvidas a respeito do biodiesel, que é um combustível menos poluente do que aqueles oriundos do petróleo (Gonçalves, 2015). Porém, no seu processo produtivo convencional (através da reação de transesterificação com óleo vegetal e metanol), há grande formação de efluente líquido na etapa de purificação. Essa problemática, aliada ao descarte inadequado de efluentes, merece grande atenção, por apresentar alto potencial poluidor, em especial aos corpos hídricos nos quais os efluentes são descartados (Santos, 2013).

A aplicação de resíduos siderúrgicos industriais em tecnologias de tratamento de efluentes apresenta caráter inovador e sustentável, visto o reaproveitamento de resíduo sem valor agregado (Oliveira, 2014). Aliado a isso, o processo de adsorção tem ganhado espaço, sendo uma técnica de tratamento de elevada eficiência e amplamente utilizada para a remoção de compostos orgânicos dissolvidos em efluentes. Neste panorama, a utilização de resíduos siderúrgicos na adsorção é promissora (Andrade et al., 2012; Santos, 2013).

O presente trabalho teve como objetivos avaliar os parâmetros físico-químicos (demanda química de oxigênio (DQO), pH, turbidez e condutividade) do efluente, caracterizar os resíduos siderúrgicos quanto à granulometria. Por meio de ensaios de adsorção, foram

estabelecer as condições ótimas para o processo, como $\mathrm{pH}$ do efluente, granulometria e concentração do resíduo, a fim de se realizar o estudo cinético e avaliar a eficiência da adsorção no processo de tratamento do efluente.

\section{METODOLOGIA}

0 pó de Alto-Forno (PAF) e o pó de minério (PM), cedidos por uma empresa siderúrgica regional, foram caracterizados quanto à sua granulometria, utilizando um agitador de peneiras marca Solotest. 0 efluente submetido ao tratamento foi gerado na primeira lavagem do biodiesel, produzido pela reação de transesterificação com óleo residual de fritura e metanol, catalisada por hidróxido de potássio. 0 efluente foi caracterizado quanto à sua DQO, turbidez, condutividade e pH (APHA, 2005).

Os parâmetros ótimos foram definidos a partir de testes de adsorção, variando-se o pH do efluente, concentração e granulometria de resíduo. Para se definir pH ótimo, três amostras do efluente foram preparadas, sendo a amostra 1 com o pH 2,5 (ácido), amostra 2 com pH 6,8 (neutro) e amostra 3 com o pH 9,0 (básico), fixando-se concentração e granulometria do resíduo, volume do efluente $(20 \mathrm{~mL})$ e tempo de reação. Para a concentração ótima de resíduo, utilizaram-se quatro concentrações diferentes $(1,10,50$ e 100 g/L). Para granulometria ótima, utilizaram-se partículas com diâmetro de 0,075, 0,5 e 1,7 mm.

Após estabelecidas as melhores condições de tratamento, realizou-se estudo cinético. 0 efluente foi submetido à adsorção com o PAF e o PM por 24 horas, e, do início até o final (0 a $1440 \mathrm{~min}$ ), foram realizadas análises de DQO. A partir dos resultados cinéticos, avaliou-se a eficiência da adsorção com ambos os resíduos siderúrgicos no tratamento do efluente do biodiesel.

\section{RESULTADOS E DISCUSSÕES}

A partir da análise granulométrica do PAF e PM, foram constatadas variações dos diâmetros dos resíduos. Observou-se uma maior fração de finos de diâmetro inferior a 0,075 mm para o PAF e uma maior fração de partículas com diâmetro superior a 2,75 mm para o PM.

Com relação ao efluente bruto, este apresentou pH 9,3, turbidez de 29000 FAU, condutividade de 1884 $\mu \mathrm{S} / \mathrm{cm}$ e DQO de 304111,11 mg de 02/. A água residuária mostrou-se com valor muito elevado de DQO, justificado pela alta concentração de carga orgânica nele presente.

Nos ensaios para definir o pH ótimo de adsorção, a partir da DQO do efluente tratado, observou-se maior remoção de DQO nas amostras com pH 2,5, conforme apresentado na Figura 1 A. A partir do pH ótimo, realizaram-se ensaios para diferentes diâmetros e concentrações dos resíduos, sendo constatado melhor resultado na remoção da DQO para $1 \mathrm{~g} / \mathrm{L}$ de resíduo (Figura $1 \mathrm{~B}$ ) e para o menor diâmetro obtido na classificação granulométrica (Figura $1 \mathrm{C}$ ). Estas condições foram válidas para ambos os resíduos avaliados neste estudo. 
Figura 1 - pH ótimo de efluente (A), concentração ótima (B) e granulometria ótima de resíduo (C) para adsorção.

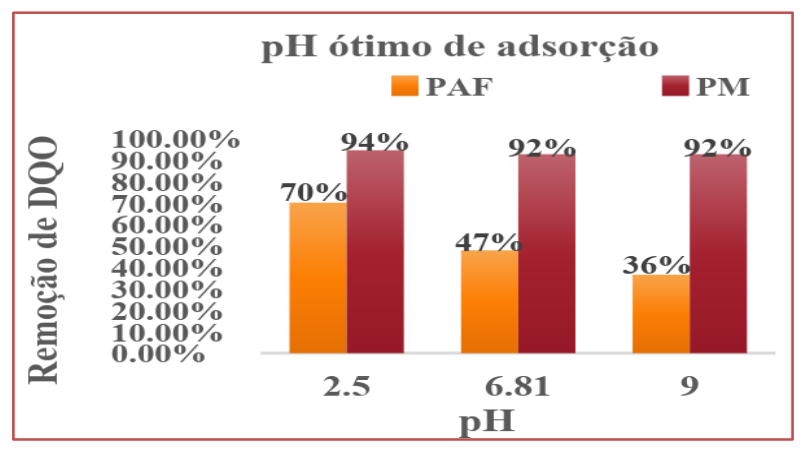

(a)

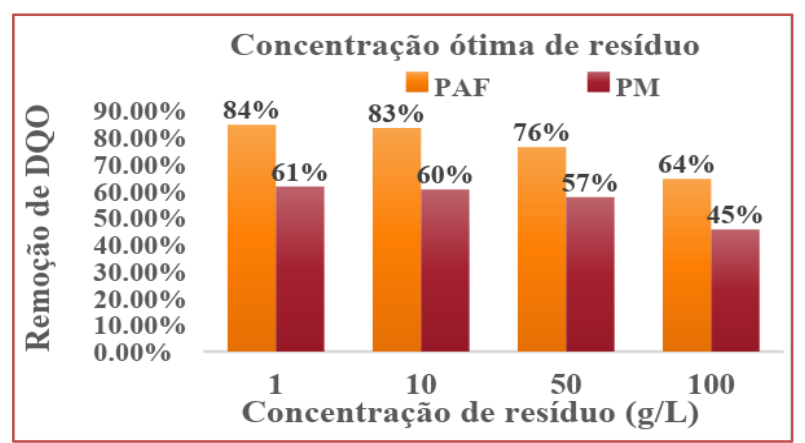

(b)

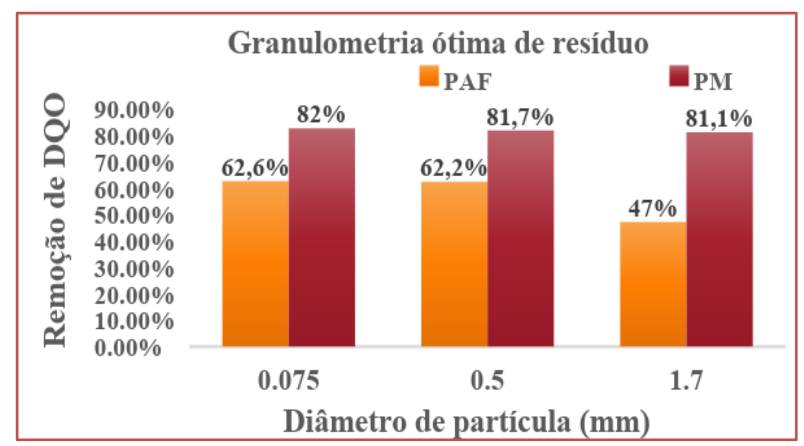

(c)

Durante o estudo cinético, observou-se que para os momentos iniciais da adsorção (entre 0 e 120 min), a remoção de DQO permaneceu em torno de 55 a 62,5\% da DQO do efluente inicial. Após os 120 min de adsorção, a remoção de DQO aumenta para cerca de $90 \%$ dando ao efluente uma aparência mais límpida do que antes. 0 equilíbrio foi constatado no final dos $1440 \min (24 \mathrm{~h})$ de adsorção, conferindo ao efluente uma remoção de DQO de aproximadamente $82 \%$ tanto para o PAF, quanto para o PM (figura 2).

Figura 2 - Cinética da adsorção

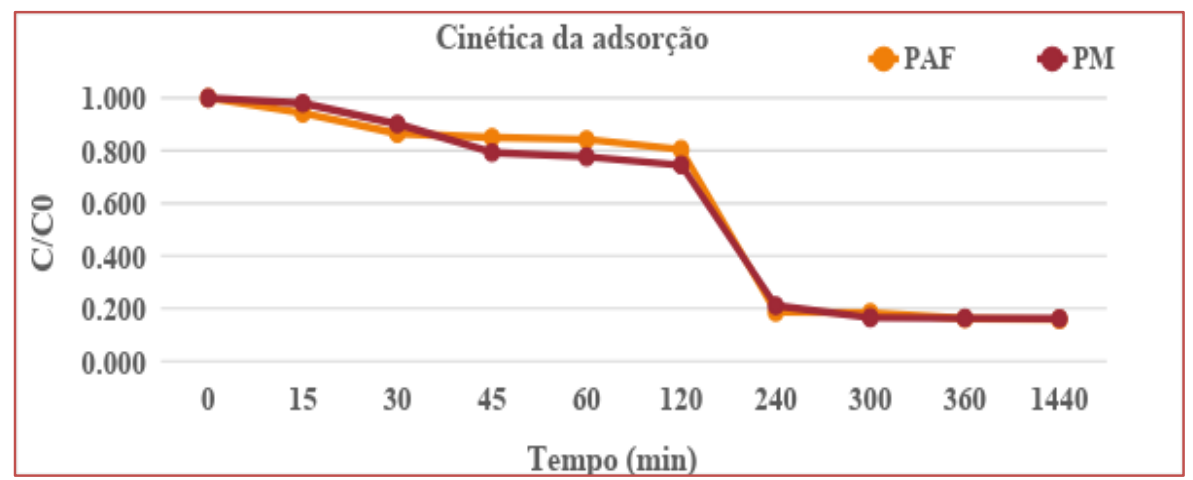

Os resultados obtidos demonstraram que, para ambos os resíduos, a adsorção apresentou maior adequação ao modelo de pseudo-primeira ordem, conforme a tabela 1. 
Tabela 1 - Adequação aos modelos de pseudo-prmeira e pseudo-segunda ordem para o PAF e PM

\begin{tabular}{|c|c|c|c|c|}
\hline Ordem & \multicolumn{2}{|c|}{ pseudo-primeira ordem } & \multicolumn{2}{|c|}{ pseudo-segunda ordem } \\
\hline resíduo & PAF & PM & PAF & $\mathrm{PM}$ \\
\hline $\mathrm{R}^{2}$ & 0,9368 & 0,9479 & 0,7694 & 0,8061 \\
\hline $\mathrm{K}$ & $0,016031 \mathrm{~s}-1$ & $0,019310 \mathrm{~s}-1$ & 2,76E-07 L.mg-1 & 4,02E-07L.mg-1 \\
\hline
\end{tabular}

\section{CONCLUSÃo}

A água residuária gerada nas etapas de lavagem do biodiesel apresentou alta carga orgânica e turbidez, confirmando a necessidade de tratamento para seu descarte adequado. No equilíbrio de adsorção, obtevese remoção da DQO de aproximadamente $80 \%$, o que comprova a eficiência do processo. Conclui-se ainda que o reaproveitamento do PAF e do PM como material adsorvente para tratamento de efluente oriundo da produção do biodiesel é viável e de grande vantagem, favorecendo a sustentabilidade dos processos produtivos.

\section{REFERÊNCIAS}

[1] ANDRADE, L. N.; TEIXEIRA, I. F.; LEÃO, M. M. D.; LAGO, R. M.; AMORIM, C. C. Investigação da capacidade de adsorção/regeneração de resíduo siderúrgico para tratamento de efluentes oleosos. In: Anais do 9o EBA IBA Encontro Brasileiro sobre Adsorção \& 1 Simpósio Ibero-Americano sobre Adsorção. Recife 2012.

[2] APHA - AMERICAN PUBLIC HEALTH ASSOCIATION. Standard methods for examination of water and wastewater. 21aㅡ ed., Washington D.C., USA, 2005.

[3] GONÇALVES, L. O. Tratamento de efluente da produção de biodiesel pelas combinações de processos biológicos e oxidativos avançados. 2015. 118f. Dissertação (Mestrado em Saneamento, Meio Ambiente e Recursos Hídricos) - Escola de Engenharia da Universidade Federal de Minas Gerais, Belo Horizonte 2015.

[4] OLIVEIRA, I. S. Utilização de resíduo siderúrgico como material alternativo no tratamento de efluentes. 2014. 62 f. Trabalho Final de Curso (Engenheiro Ambiental e Sanitarista) - Universidade Federal de Juiz de Fora, Juiz de Fora. 2014.

[5] SANTOS, A. M. M. Tratamento de efluentes de biodiesel pelo processo combinado de coagulação-floculação e fenton. 2014. 81f. Dissertação (Mestrado em Saneamento, Meio Ambiente e Recursos Hídricos) - Escola de Engenharia da Universidade Federal de Minas Gerais, Belo Horizonte 2014.

[6] SANTOS, V. S. Utilização de resíduos siderúrgicos como adsorventes de baixo custo no tratamento de efluentes contendo emulsões oleosas. 2013. 99 f. Dissertação (Mestrado em Meio Ambiente e Recursos Hídricos) Programa de Pós-graduação em Saneamento, Meio Ambiente e Recursos Hídricos, Universidade Federal de Minas Gerais, Belo Horizonte. 2013. 


\section{Capítulo 15}

Otimização do tratamento de água de manancial com baixa turbidez e cor elevada utilizando filtração direta e dupla filtração

Bruno Castro Barbalho

André Luis Lopes Moriyama

André Luis Calado Araújo

André Luis Santos de Pinho

Resumo: Estudos e pesquisas realizados no Rio Grande do Norte evidenciam tendência crescente e contínua de eutrofização dos mananciais superficiais, por resíduos oriundos das atividades antrópicas acarretando diversos riscos para a saúde humana. Para tal situação, é essencial que estudos sejam realizados para a escolha de uma configuração de tecnologias de tratamento de água capaz de garantir a qualidade da água oferecida a população local. Com isso, diversas pesquisas se concentram na busca das condições ótimas de tratamento de água. Contudo, nem sempre as condições ótimas são as mais adequadas a serem implantas em estação em escala real devido estas condições sofrerem com elevadas variações durante o processo de tratamento. Desse modo, o presente trabalho avaliou, em escala piloto, as técnicas de tratamento de dupla filtração e filtração direta, com pré-oxidação e coagulação para o tratamento de água de reservatório com elevada densidade de cianobactérias, baixa turgidez e cor elevada buscando obter a condição mais robusta no processo. Os fatores de controle estudados foram a taxa de filtração e as granulometrias dos filtros decendentes e ascendentes tendo o tempo de filtração sido considerado o fator de ruído do processo. Para a realização e análise dos experimentos foram utilizados dois planejamentos experimentais, sendo um delineamento split-plot para a filtração direta e um delineamento split-spliplot para a dupla filtração. Como resposta ao tratamento foram avaliados os parâmetros de turbidez, cor aparente, cor verdadeira, pH e absorbância dos filtros. Para ambas as configurações estudadas não foram obtidas valores de turbidez em conformidade com a Portaria de Consolidação no 5 de 2017, enquanto que nas duas configurações foram obtidos resultados de cor aparente em conformidade com a Portaria de Consolidação no 5 de 2017, tendo a dupla filtração obtido resultados mais robustos com taxa de filtração mais elevadas do que a filtração direta. Enquanto, a granulometria dos filtros descendentes pouco influenciaram nos resultados e a menor granulometria dos filtros ascendentes apresentou os piores resultados não sendo indicada para estudos posteriores.

Palavras-chave: Tratamento de água, dupla filtração, filtração direta e delineamento splitplot. 


\section{INTRODUÇÃO}

O uso inadequado dos recursos hídricos, em decorrência do desenvolvimento de atividades agrícolas, ocasionado pelo aumento das lavouras e da produção animal em regime confinado (Merten et al, 2002) e industriais, aliado a fatores relativos à urbanização desordenada e ao crescimento populacional, tem provocado a poluição dos mananciais superficiais (Silva, G.G. et al, 2012).

Com isso, à necessidade de se avaliar novas medidas de proteção a saúde pública. Estudos têm mostrado que os processos que envolvem o tratamento de água por ciclo completo não são efetivos na eliminação dos efeitos gerados pela presençaa de cianobactérias e seus subprodutos. De modo que, torna-se imprescindível o desenvolvimento e domínio de tecnologias alternativas de tratamento, ou combinações destas, adequando às condições técnicas, sociais e econômicas locais (Di Bernardo, 2005; Machado, 2011; Silva, G.G. et al, 2012.).

O processo unitário de filtração é a etapa mais importante no tratamento de água, tendo como uma das variáveis importantes para a eficiência do processo a granulometria dos filtros e a taxa de filtração. Recomenda-se o processo de filtração descendente para valores baixos de turbidez, de modo que, o processo é realizado com ação de profundidade ao longo de todo o meio filtrante. (Richter, 2017).

Segundo Di Bernardo (2005), a dupla filtração consiste em uma técnica promissora permitindo o tratamento de água com variações bruscas de qualidade, podendo utilizar taxas de filtração mais elevadas, provocando uma maior remoção de microrganismos, aumentando a segurança em relação à desinfecção final, e pode dispensar o descarte de água pré-filtrada no início da carreira de filtração.

A busca pelo desenvolvimento e aperfeiçoamento de processos de tratamento de água sejam rentáveis economicamente vem sendo o foco de diversas pesquisas em todo o mundo. Com isso, uma avaliação inicial foi realizada, de modo separado, nas dissertações de mestrado de Lima (2019), para filtração direta e de Duarte (2018), para a dupla filtração, utilizando um planejamento totalmente aleatorizado. Em ambos os trabalhos, foram obtidas as condições ótimas para cada processo. Contudo, os trabalhos não consideram o tempo de filtração como um fator que possa influenciar em cada processo. Além disso, a condição ótima pode ser sensível a variações no tempo de realização do processo, a tornando inviável do ponto de vista operacional, enquanto a condição mais robusta será menos sensível a essas variações. Portanto, o presente trabalho busca avaliar o comportamento das técnicas de dupla filtração e da filtração direta, integrada aos processos de coagulação e pré-oxidação, para o tratamento da água da proveniente da lagoa de Extremoz-RN, em estação piloto de dupla filtração utilizando o delineamento estatístico splitplot de modo a obter as condições mais robustas para cada processo.

\section{METODOLOGIA}

A pesquisa foi realizada na estação piloto de dupla filtração (IPDF), localizada na Estação de Tratamento de Água (ETA), que pertence a Companhia de Águas e Esgotos do Rio Grande do Norte - CAERN, situada no município de Extremoz no litoral do Estado do Rio Grande do Norte.

\subsection{DESCRIÇÃO DAS AMOSTRAS E ANÁLISE FÍSICO-QUÍMICA}

As amostras analisadas no presente estudo correspondem a água bruta da lagoa de Extremoz, e as águas tratadas após passagem na IPDF, utilizando as configurações de filtração descendente e dupla filtração. As análises físico-químicas realizadas foram de potencial hidrogeniônico $(\mathrm{pH})$, cor aparente, cor verdadeira, turbidez e absorbância no comprimento de onde de 254 nm (APHA, AWWA e WEF (2012).

\subsection{CARACTERISTICAS DOS FILTROS DESCENDENTES DE AREIA (FDA) E ASCENDENTES DE PEDREGULHO (FAP)}

A IPDF é composta por quatro filtros de ascendentes de pedregulho e 3 filtros descendentes de areia. As características granulométricas das camadas filtrantes e de suporte dos filtros estão descritas na Tabela 1 , 2 e 3. 
Tabela 1- Características da camada suporte dos FDA.

\begin{tabular}{|c|c|c|c|}
\hline \multicolumn{1}{|c|}{ Filtro } & Camada filtrante & Tamanho dos grãos (mm) & Espessura (cm) \\
\hline \multirow{5}{*}{ FRDA 1, 2 e 3 } & 1 (fundo) & $19,0-12,7$ & 5 \\
\cline { 2 - 4 } & 2 & $12,7-6,4$ & 5 \\
\cline { 2 - 4 } & 3 & $6,4-3,4$ & 5 \\
\cline { 2 - 4 } & 4 & $3,4-2,0$ & 5 \\
\cline { 2 - 4 } & 5 & $6,4-3,4$ & 5 \\
\cline { 2 - 4 } & 6 & $12,7-6,4$ & 5 \\
\cline { 2 - 4 } & 7 (topo) & $19,0-12,7$ & 35 \\
\hline
\end{tabular}

Fonte: adaptado de Duarte (2018).

Tabela 2 - Características das camadas filtrante dos FDA.

\begin{tabular}{|c|c|c|c|c|c|}
\hline Filtro & Camada filtrante & Tamanho dos grãos (mm) & Filtro & Camada filtrante & $\begin{array}{l}\text { Tamanho dos grãos } \\
(\mathrm{mm})\end{array}$ \\
\hline \multirow{5}{*}{ FDA 1} & 1 & $0,3-0,4$ & \multirow{5}{*}{ FDA 3} & 1 & $0,4-0,5$ \\
\hline & 2 & $0,4-0,5$ & & 2 & $0,5-0,6$ \\
\hline & 3 & $0,5-0,6$ & & 3 & $0,6-0,8$ \\
\hline & 4 & $0,6-0,8$ & & 4 & $0,8-1,0$ \\
\hline & 5 & $0,8-1,0$ & & 5 & $1,0-1,2$ \\
\hline \multicolumn{3}{|c|}{$\begin{array}{c}\mathrm{D}_{0}=0,3 \mathrm{~mm} ; \mathrm{D}_{10}=0,50 \mathrm{~mm} ; \mathrm{D}_{60}=0,81 \mathrm{~mm} ; \mathrm{D}_{100}=1,0 \mathrm{~mm} ; \\
\mathrm{CD}=1,62\end{array}$} & & & 6 \\
\hline \multirow{6}{*}{ FDA 2} & 1 & $0,3-0,4$ & \multicolumn{3}{|c|}{$\begin{array}{c}\mathrm{D}_{0}=0,4 \mathrm{~mm} ; \mathrm{D}_{10}=0,87 \mathrm{~mm} ; \mathrm{D}_{60}=1,45 \mathrm{~mm} ; \mathrm{D}_{100}=1,7 \\
\mathrm{~mm} ; \mathrm{CD}=1,67\end{array}$} \\
\hline & 2 & $0,4-0,5$ & & & \\
\hline & 3 & $0,5-0,6$ & \multirow{5}{*}{\multicolumn{3}{|c|}{$\begin{array}{l}\text { Legenda: } \mathrm{D}_{0} \text { : diâmetro do menor grão; } \mathrm{D}_{10} \text { : diâmetro } \\
\text { efetivo; } \mathrm{D}_{60} \text { : diâmetro tal que } 60 \% \text { do solo, em massa, } \\
\text { têm diâmetros menores que ele }(\mathrm{mm}) ; \mathrm{D}_{100}= \\
\text { diâmetro do maior grão; CD: coeficiente de } \\
\text { desuniformidade. }\end{array}$}} \\
\hline & 4 & $0,6-0,8$ & & & \\
\hline & 5 & $0,8-1,0$ & & & \\
\hline & 6 & $1,0-1,2$ & & & \\
\hline \multicolumn{3}{|c|}{$\begin{array}{c}\mathrm{D}_{0}=0,3 \mathrm{~mm} ; \mathrm{D}_{10}=0,57 \mathrm{~mm} ; \mathrm{D}_{60}=1,05 \mathrm{~mm} ; \mathrm{D}_{100}=1,2 \mathrm{~mm} ; \\
\mathrm{CD}=1,84\end{array}$} & & & \\
\hline
\end{tabular}

Fonte: Duarte (2011) 
Tabela 3 - Características físicas das camadas filtrantes e suporte dos filtros FAP.

\begin{tabular}{|c|c|c|c|c|c|c|c|}
\hline Filtro & $\begin{array}{l}\text { Camada } \\
\text { Filtrante }\end{array}$ & $\begin{array}{l}\text { Tamanho dos Grãos } \\
(\mathrm{mm})\end{array}$ & $\begin{array}{l}\text { Espessura } \\
(\mathrm{cm})\end{array}$ & | Filtro & Camada Filtrante & $\begin{array}{l}\text { Tamanho dos Grãos } \\
(\mathrm{mm})\end{array}$ & $\begin{array}{c}\text { Espessura } \\
(\mathrm{cm})\end{array}$ \\
\hline \multirow{5}{*}{ FAP 1} & 1 (Fundo) & $19,0-25,4$ & 15 & \multirow{5}{*}{ FAP 3} & 1 (Fundo) & $15,9-25,4$ & 15 \\
\hline & 2 & $12,7-19,0$ & 15 & & 2 & $9,615,9$ & 15 \\
\hline & 3 & $7,9-12,7$ & 30 & & 3 & $4,8-9,6$ & 30 \\
\hline & 4 (Торо) & $4,8-7,9$ & 60 & & 4 (Торо) & $2,4-4,8$ & 60 \\
\hline & \multicolumn{2}{|c|}{ Espessura total } & 120 & & & Espessura total & 120 \\
\hline \multirow{5}{*}{ FAP 2} & 1 (Fundo) & $19,0-25,4$ & 15 & \multirow{5}{*}{ FAP 4} & 1 (Fundo) & $12,7-19,0$ & 15 \\
\hline & 2 & $12,7-19,0$ & 15 & & 2 & $6,4-12,7$ & 15 \\
\hline & 3 & $6,4-12,7$ & 30 & & 3 & $3,2-6,4$ & 30 \\
\hline & 4 (Торо) & $3,2-6,4$ & 60 & & 4 (Торо) & $2,0-3,2$ & 60 \\
\hline & \multicolumn{2}{|c|}{ Espessura total } & 120 & & & Espessura total & 120 \\
\hline
\end{tabular}

Fonte: adaptado de Duarte (2011).

\subsection{ENSAIOS NA IPDF}

Os ensaios foram realizados em duas configurações distintas, tendo ambas carreiras de filtração com duração de 8 horas. Na primeira configuração, correspondendo ao processo de filtração direta e a segunda configuração, correspondendo a dupla filtração. Para ambas as configurações foram fixadas a dose de cloro na etapa de pré-oxidação de $3 \mathrm{mg} / \mathrm{L}$ e a dose de coagulante hidróxido cloreto de alumínio (PAC$23 \%$ ) de $6 \mathrm{mg} / \mathrm{L}$ para coagulação. Em seguida serão descritas as configurações utilizadas na estação piloto para o presente estudo.

\subsubsection{FILTRAÇÃO DIRETA}

Os ensaios para a filtração direta envolveram as etapas de pré-oxidação, coagulação e filtração descendente em filtros de areia. No início de cada carreira de filtração, os filtros eram lavados com expansão da altura do meio filtrante em $25 \%$ por 8 minutos. Após a lavagem dos filtros a bomba de recalque de água bruta alimentava duas caixas de pré-oxidação, onde foi adicionada uma solução clorada a água bruta. Em seguida, a mesma foi bombeada para a caixa de mistura rápida, onde a água bruta recebeu a dose de coagulante. Em seguida, a água coagulada foi direcionada para os filtros descendentes de areia abrindo o registro de entrada para os três FDA. Os registros de saída de água filtrada foram abertos para que se inicie o processo de filtração. Uma vez estabilizado o nível d'água nos filtros era iniciado o tempo da carreira de filtração. Uma hora após o seu início, era efetuada a primeira coleta de amostras de água filtrada e de água bruta, logo após efetua-se a primeira leitura dos piezômetros dos três FDA. As coletas da água filtrada e a leitura dos piezômetros foram efetuados a cada hora, como também, foi verificando a vazão dos filtros através dos rotâmetros, a fim de assegurar que a vazão de alimentação estivesse garantindo a taxa de filtração desejada.

A interrupção da carreira de filtração era definida pela ocorrência de turbidez da água filtrada superior a 1,0 UNT ou perda de carga superior ao limite estabelecido pelo sistema. No encerramento da carreira de filtração de um filtro qualquer, era realizado a sua lavagem.

Para os ensaios foi realizado um planejamento em que foram testados quatro níveis para as taxas de filtração, 253, 280, 310 e $340 \mathrm{~m}^{3} / \mathrm{m}^{2}$.dia, e três níveis de granulometria, representados nos três filtros descendentes de areia, descritos nas Tabelas 1 e 2. Com isso, o planejamento apresentou 12 blocos de ensaios, com os três FDA sendo utilizados ao mesmo tempo totalizando 36 ensaios. Cada ensaio foi realizado com duas replicas, como mostra a Tabela 4. 
Tabela 4 - Planejamento experimental para os ensaios na IPDF na configuração de filtração direta.

\begin{tabular}{|c|c|c|c|c|c|c|c|c|}
\hline Blocos & Ensaios & FDA (G-Tx) & Blocos & Ensaios & FDA (G-Tx) & Blocos & Ensaios & FDA (G-Tx) \\
\hline \multirow{3}{*}{1} & 1 & FDA (1-253) & \multirow{3}{*}{5} & 13 & FDA $(1-253)$ & \multirow{3}{*}{9} & 25 & FDA (1-253) \\
\hline & 2 & FDA (2-253) & & 14 & FDA (2-253) & & 26 & FDA (2-253) \\
\hline & 3 & FDA (3-253) & & 15 & FDA (3-253) & & 27 & FDA (3-253) \\
\hline \multirow{3}{*}{2} & 4 & FDA $(1-280)$ & \multirow{3}{*}{6} & 16 & FDA $(1-280)$ & \multirow{3}{*}{10} & 28 & FDA (1-280) \\
\hline & 5 & FDA (2-280) & & 17 & FDA $(2-280)$ & & 29 & FDA (2-280) \\
\hline & 6 & FDA (3-280) & & 18 & FDA $(3-280)$ & & 30 & FDA (3-280) \\
\hline \multirow{3}{*}{3} & 7 & FDA (1-310) & \multirow{3}{*}{7} & 19 & FDA (1-310) & \multirow{3}{*}{11} & 31 & FDA (1-310) \\
\hline & 8 & FDA (2-310) & & 20 & FDA $(2-310)$ & & 32 & FDA $(2-310)$ \\
\hline & 9 & FDA (3-310) & & 21 & FDA $(3-310)$ & & 33 & FDA $(3-310)$ \\
\hline \multirow{3}{*}{4} & 10 & FDA (1-340) & \multirow{3}{*}{8} & 22 & FDA $(1-340)$ & \multirow{3}{*}{12} & 34 & FDA $(1-340)$ \\
\hline & 11 & FDA $(2-340)$ & & 23 & FDA $(2-340)$ & & 35 & FDA $(2-340)$ \\
\hline & 12 & FDA (3-340) & & 24 & FDA (3-340) & & 36 & FDA $(3-340)$ \\
\hline
\end{tabular}

\subsubsection{DUPLA FILTRAÇÃO}

Os ensaios para a dupla filtração envolveram as etapas de pré-oxidação, coagulação, filtração em filtros ascendentes de pedregulho e filtração descendente em filtros de areia. No início de cada carreira de filtração, os FDA eram lavados com expansão de $25 \%$ do meio filtrante por 8 minutos, assim como os FAP também era lavados por 8 minutos. Após lavagem a bomba de recalque de água bruta alimenta a caixa de pré-oxidação, onde foi adicionada uma solução clorada a água bruta. Em seguida a mesma será bombeada para a caixa de mistura rápida, onde a água bruta recebeu a dose de coagulante. Em seguida, a água coagulada é direcionada para os filtros ascendentes de pedregulho, sendo usado um FAP por ensaio. Após o preenchimento do FAP era considerado o início da pré-filtração, em que a água pré-filtrada era direcionada para os três filtros descendentes de areia abrindo-se o registro de entrada para os mesmo. Os registros de saída de água filtrada foram abertos para que se inicie o processo de filtração.

Uma vez estabilizado o nível d'água nos filtros era iniciado o tempo da carreira de filtração. Uma hora após o seu início, era efetuada a primeira coleta de amostras de água filtrada e de água bruta, logo após efetuase a primeira leitura dos piezômetros do FAP e dos três FRDA. As coletas da água filtrada e a leitura dos piezômetros foram efetuados a cada hora, como também, foi verificando a vazão dos filtros, a fim de assegurar que a vazão de alimentação estivesse garantindo a taxa de filtração desejada.

Para os ensaios na IPDF com configuração para o processo em dupla filtração, foi realizado um planejamento em que foram testados quatro níveis para as taxas de filtração, 253, 280, 310 e 340 $\mathrm{m}^{3} / \mathrm{m}^{2}$.dia, e três níveis de granulometria dos FDA (Tabelas 1 e 2) e quatro níveis de granulometria dos FAP (Tabela 3). Com isso, o planejamento apresentou 16 ensaios, sendo cada ensaio realizado com uma replica, totalizando 32 ensaios como mostra a Tabela 5. 0 tempo da carreira de filtração de 8 horas foi considerada como fator de ruído. 
Tabela 5 - Planejamento experimental para os ensaios na IPDF na configuração de dupla filtração

\begin{tabular}{|c|c|c|c|c|c|}
\hline Ensaio & FAP (G-Tx) & FDA (G-Tx) & Ensaio & FAP (G-Tx) & FDA (G-Tx) \\
\hline \multirow{3}{*}{1} & \multirow{3}{*}{ FAP (1-190) } & FDA (1-253) & \multirow{3}{*}{9} & \multirow{3}{*}{ FAP (1-230) } & FDA $(1-310)$ \\
\hline & & FDA (2-253) & & & FDA $(2-310)$ \\
\hline & & FDA (3-253) & & & FDA $(3-310)$ \\
\hline \multirow{3}{*}{2} & \multirow{3}{*}{ FAP $(2-190)$} & FDA (1-253) & \multirow{3}{*}{10} & \multirow{3}{*}{ FAP $(2-230)$} & FDA $(1-310)$ \\
\hline & & FDA (2-253) & & & FDA $(2-310)$ \\
\hline & & FDA (3-253) & & & FDA $(3-310)$ \\
\hline \multirow{3}{*}{3} & \multirow{3}{*}{ FAP (3-190) } & FDA (1-253) & \multirow{3}{*}{11} & \multirow{3}{*}{ FAP (3-230) } & FDA $(1-310)$ \\
\hline & & FDA (2-253) & & & FDA $(2-310)$ \\
\hline & & FDA (3-253) & & & FDA $(3-310)$ \\
\hline \multirow{3}{*}{4} & \multirow{3}{*}{ FAP (4-190) } & FDA (1-253) & \multirow{3}{*}{12} & \multirow{3}{*}{ FAP (4-230) } & FDA $(1-310)$ \\
\hline & & FDA (2-253) & & & FDA $(2-310)$ \\
\hline & & FDA (3-253) & & & FDA $(3-310)$ \\
\hline \multirow{3}{*}{5} & \multirow{3}{*}{ FAP $(1-210)$} & FDA (1-280) & \multirow{3}{*}{13} & \multirow{3}{*}{ FAP (1-255) } & FDA $(1-340)$ \\
\hline & & FDA $(2-280)$ & & & FDA $(2-340)$ \\
\hline & & FDA (3-280) & & & FDA $(3-340)$ \\
\hline \multirow{3}{*}{6} & \multirow{3}{*}{ FAP $(2-210)$} & FDA $(1-280)$ & \multirow{3}{*}{14} & \multirow{3}{*}{ FAP (2-255) } & FDA $(1-340)$ \\
\hline & & FDA $(2-280)$ & & & FDA $(2-340)$ \\
\hline & & FDA (3-280) & & & FDA $(3-340)$ \\
\hline \multirow{3}{*}{7} & \multirow{3}{*}{ FAP $(3-210)$} & FDA $(1-280)$ & \multirow{3}{*}{15} & \multirow{3}{*}{ FAP (3-255) } & FDA $(1-340)$ \\
\hline & & FDA $(2-280)$ & & & FDA $(2-340)$ \\
\hline & & FDA (3-280) & & & FDA $(3-340)$ \\
\hline \multirow{3}{*}{8} & \multirow{3}{*}{ FAP (4-210) } & FDA $(1-280)$ & \multirow{3}{*}{16} & \multirow{3}{*}{ FAP (4-255) } & FDA $(1-340)$ \\
\hline & & FDA $(2-280)$ & & & FDA $(2-340)$ \\
\hline & & FDA (3-280) & & & FDA $(3-340)$ \\
\hline
\end{tabular}

A interrupção da carreira de filtração no FDA era realizada o mesmo procedimento aplicado a filtração direta. Para o FAP, a descarga de fundo intermediaria (DFI) era realizada assim que a turbidez remanescente do FAP se elevava 50 \% quando comparado a turbidez da coleta anterior.

\subsection{ANÁLISE ESTATÍSTICA DOS DADOS}

Para a análise dos resultados foram calculados parâmetros estatísticos, tais como, médias aritméticas e geométrica para estimar a tendência central, o intervalo máximo e mínimo, e a ANOVA. Os efeitos principais e de interação, entre as características do meio filtrante, das taxas de filtração, o tempo de filtração e a qualidade da água tratada, serão analisados com um intervalo de confiança de 95 \%. Nessa analise o tempo de filtração será considerado como um fator de ruído para avaliar a robustez dos processos. Para essa avaliação foi utilizado o delineamento splitplot para a configuração da filtração direta e o delineamento split-split plot para a configuração de dupla filtração. 


\section{RESULTADOS E DISCUSSÕES}

\subsection{CARACTERÍSTICAS DA ÁGUA BRUTA}

Tabela 6 - Características da água bruta para os ensaios em filtração direta (FD) e dupla fltração (DF)

\begin{tabular}{|c|c|c|c|c|c|c|c|c|}
\hline \multirow{2}{*}{ Variável } & \multicolumn{2}{|c|}{ Mínimo } & \multicolumn{2}{|c|}{ Média } & \multicolumn{2}{|c|}{ Máximo } & \multicolumn{2}{|c|}{ Desvio Padrão } \\
\hline & $\mathrm{FD}$ & DF & FD & DF & FD & DF & FD & DF \\
\hline Temperatura $\left({ }^{\circ} \mathrm{C}\right)$ & 26 & 23,8 & 27 & 27,7 & 28 & 32,9 & 1,0 & 1,4 \\
\hline $\mathrm{pH}$ & 7,56 & 7,3 & 7,70 & 7,3 & 7,80 & 8,3 & 0,1 & 0,2 \\
\hline Turbidez (UNT) & 2,20 & 1,7 & 3,16 & 3,9 & 6,37 & 8,3 & 1,1 & 1,2 \\
\hline Cor Aparente (uH) & 22 & 42 & 27 & 30 & 35 & 42 & 4,0 & 5 \\
\hline Cor Verdadeira $(\mathrm{uH})$ & 8 & 7 & 13 & 14 & 24 & 26 & 5,0 & 6 \\
\hline $\mathrm{ABS}_{254}\left(\mathrm{~cm}^{-1}\right)$ & 0,09 & 0,02 & 0,16 & 0,16 & 0,18 & 0,21 & 0,1 & 0,03 \\
\hline
\end{tabular}

Fonte: FD - Lima (2019); DF - Duarte (2018).

Os ensaios de filtração direta em leito simples de areia foram realizados nos períodos de março a julho de 2017 e os ensaios de dupla filtração foram realizados nos períodos de março a agosto de 2017. A Tabela 6 mostra as características da água bruta para ambos os períodos em que os experimentos foram realizados.

Observa-se que os resultados obtidos por Lima (2019) e Duarte (2018) são semelhantes aos obtidos por Freitas (2017) em estudos realizados na Lagoa de Extremoz, mostrando características de baixa turbidez, cor aparente elevada e $\mathrm{pH}$ levemente alcalino.

\subsection{AVALIAÇÃO DA ROBUSTEZ DAS VARIÁVEIS DE CONTROLE PARA A FILTRAÇÃO DIRETA}

Com o objetivo de avaliar a robustez e encontrar a condição menos sensível a variações no experimento para os FDAs, foram avaliados para cada variável resposta quais os efeitos e interações foram significativas, considerando o tempo de filtração como um fator de ruído e para um valor de $\mathrm{p}$ menor que $0,05(\alpha=5 \%)$.

A Tabela 7 apresenta os resultados do valor de P obtidos para os efeitos principais e de interação de cada parâmetro analisado.

Tabela 7- Valores de P do planejamento splitplot para a filtração direta.

\begin{tabular}{|l|c|c|c|c|c|}
\hline \multirow{2}{*}{ Fonte de Variação } & Turbidez & $\begin{array}{c}\text { Cor } \\
\text { Aparente }\end{array}$ & $\begin{array}{c}\text { Cor } \\
\text { Verdadeira }\end{array}$ & ABS & pH \\
\hline TXT & 0,591 & 0,000409 & 0,00234 & $7,62 \times 10-5$ & 0,135 \\
\hline FDA & 0,411 & 0,774647 & 0,72809 & 0,519 & 0,301 \\
\hline TXT: FDA & 1 & 0,999956 & 0,99982 & 0,989 & 0,99 \\
\hline \multicolumn{7}{|c|}{ Error Parcela } \\
\hline Tempo & 0,4511 & $8,5 \times 10^{-5}$ & 0,141 & 0,0105 & 0,071897 \\
\hline Tempo: TXT & 0,0446 & 0,247 & 0,384 & 0,0967 & 0,000116 \\
\hline Tempo: FDA & 0,9085 & 0,988 & 0,418 & 0,2005 & 0,883992 \\
\hline Tempo: TXT: FDA & 1 & 0,991 & 0,958 & 0,9459 & 1 \\
\hline
\end{tabular}

TXT - Taxa de Filtração; FDA - Filtro descendente de areia; Tempo - tempo da carreira de filtração

Observando a Tabela 7, para o parâmetro da Turbidez, verifica-se na sub-parcela que o efeito de interação de segunda ordem entre o tempo de filtração e a taxa de filtração são estatisticamente significantes, com tal interação mostrada na Figura 3. Observa-se que as taxas de filtração nos valores de 310 e 340 $\mathrm{m}^{3} / \mathrm{m}^{2}$.dia apresentaram uma significativa variação no seu comportamento nas 8 horas de filtração. Contudo, as taxas de filtração de 253 e $280 \mathrm{~m}^{3} / \mathrm{m}^{2}$.dia apresentaram uma menor variação nos seus 
resultados indicando que essas taxas de filtração são menos sensíveis ao longo da carreira de filtração, tendo a taxa de filtração de $280 \mathrm{~m}^{3} / \mathrm{m}^{2}$.dia apresentado os menores valores médios de turbidez.

Entretanto, para todas as taxas de filtração estudadas a média dos valores de turbidez estão acima do valor permitido pela Portaria da Consolidação n 5/2017 (Brasil, 2017).

Figura 3 - Gráfico da interação de segunda ordem entre a taxa de filtração e o tempo de filtração.

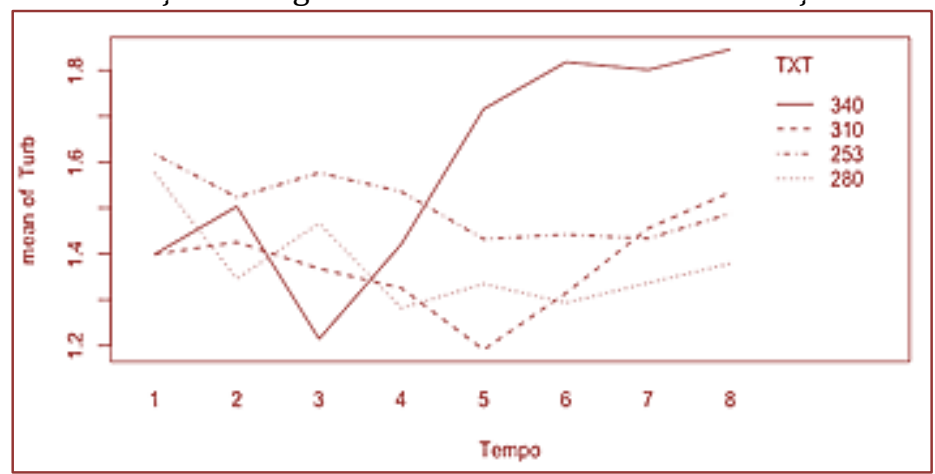

A Figura 4 apresenta os gráficos de resíduos dos resultados da análise de turbidez. Observa-se que em grande parte os resultados aparecem aleatoriamente dispersos em ambos os lados e próximos de zero (Figura 4 (a) e (d)), como também, os resíduos ao serem padronizados, apresentaram seus valores distribuídos aleatoriamente próximo de 1 com uma pequena inclinação positiva. Os resultados seguem uma distribuição normal devido os pontos se aproximarem de uma linha reta (Figura 4.2 (b)). Na Figura 4 (c), percebe-se os valores obtidos para a turbidez estão entre os valores 1,0 e 1,5, com uma baixa dispersão dos resultados.

Figura 4 - Gráficos de resíduos para a variável resposta turbidez. (a) Gráfico de resíduos em função dos valores ajustados; (b) Gráfico de probabilidade normal; (c) Gráfico de resíduos padronizados em função dos valores ajustados; e (d) Gráfico de resíduos padronizados em função dos níveis dos fatores.

$$
\text { a) }
$$

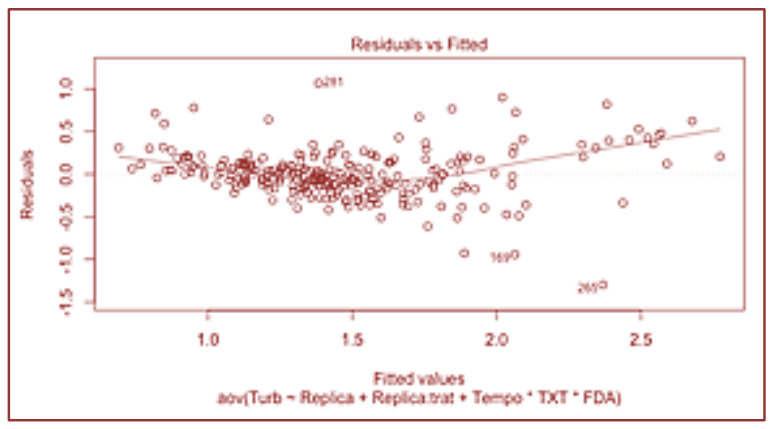

c)

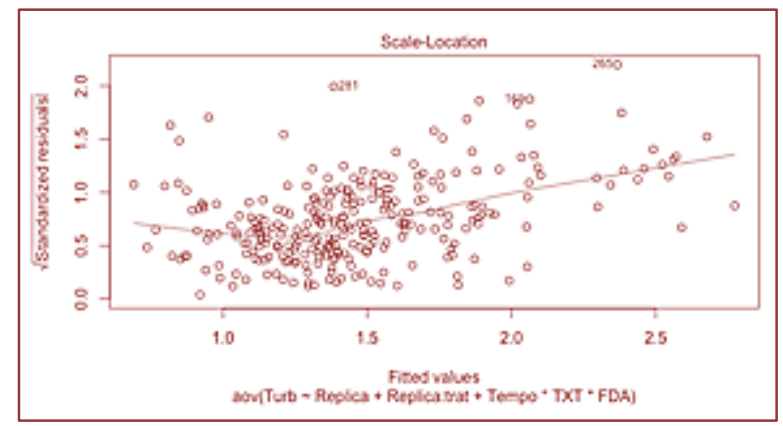

b)

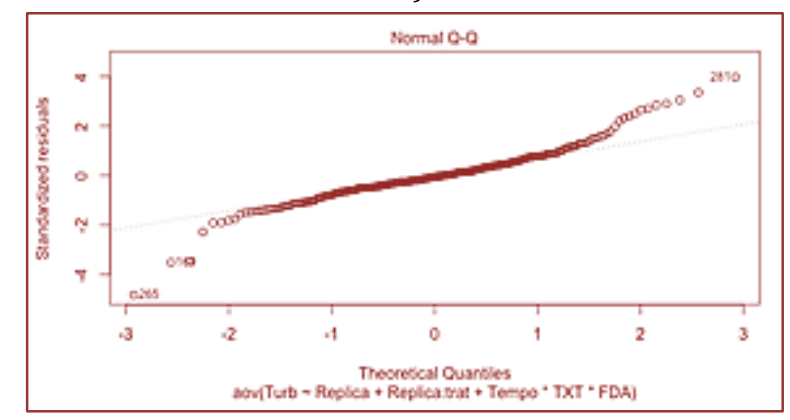

d)

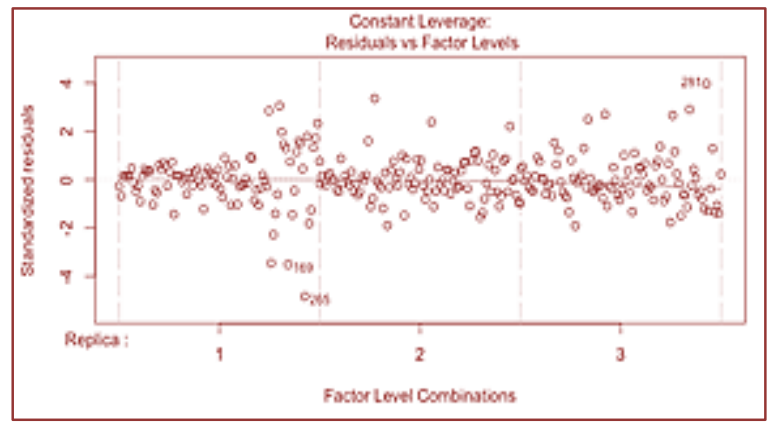


Contudo, nota-se nos gráficos a existência de pontos distantes da curva, em que o ponto mais elevado pode estar relacionado com uma lavagem do filtro, realizada de modo ineficiente, antes de iniciar o ensaio e os valores mais baixos podem estar relacionados com a complementação do meio filtrante, que tinha sido perdida após a lavagem dos filtros no ensaio anterior.

Enquanto que, avaliando na Tabela 7 o valor de p, para a cor aparente, tem-se que na parcela o efeito principal da taxa de filtração (Figura 5(a)) e da subparcela de tempo de filtração (Figura 5 (b)) foram estatisticamente significativos

Na Figura 5 (a), o gráfico é semelhante ao que foi obtido por Lima (2019), em que as taxas de filtração de 253 e $280 \mathrm{~m}^{3} / \mathrm{m}^{2}$.dia apresentaram comportamentos diferentes das taxas de 310 e $340 \mathrm{~m}^{3} / \mathrm{m}^{2}$.dia, enquanto estes apresentaram comportamentos estatísticos semelhantes entre si. 0 valor médio mais alto foi obtido para a taxa de filtração de $253 \mathrm{~m}^{3} / \mathrm{m}^{2}$.dia, com este estando acima do valor permitido pela Portaria da Consolidação n ${ }^{\circ}$ 5/2017 (Brasil, 2017). Para a outras taxas os valores médios obtidos estão dentro das especificações da Portaria da Consolidação n ${ }^{\circ}$ 5/2017 (BRASIL, 2017), tendo o menor valor médio sendo obtido na taxa de filtração de $280 \mathrm{~m}^{3} / \mathrm{m}^{2}$.dia. Já na Figura 5 (b), tem-se a relação entre os resultados da cor aparente em função do tempo de filtração. Observa-se que ao longo do tempo os valores médios para a cor aparente encontram-se abaixo $15 \mathrm{uH}$, dentro das especificações da Portaria da Consolidação ${ }^{\circ}$ 5/2017 (Brasil, 2017), com baixa variação nas duas primeiras horas de ensaio.

Contudo, após o período de 3 horas os valores médios para a cor aparente apresentaram um aumento no decorrer do tempo da filtração devido o acúmulo de impurezas que vão sendo retidas ao logo do meio filtrante diminuindo a eficiência do filtro. Quando o filtro satura, o processo deve ser interrompido para ser realizado a lavagem do mesmo.

Figura 5 - Gráficos que relacionam (a) os níveis das taxas de filtração com o valor médio da cor aparente; e (b) os níveis do tempo de filtração com o valor médio da cor aparente.

a)

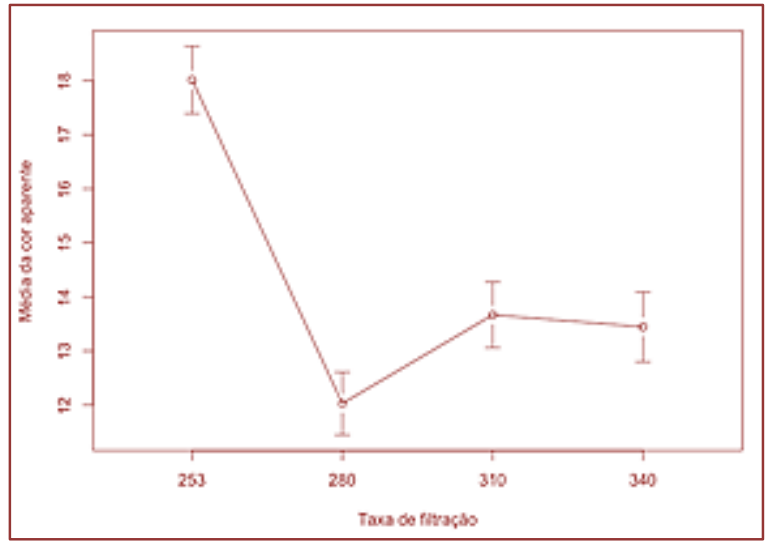

b)

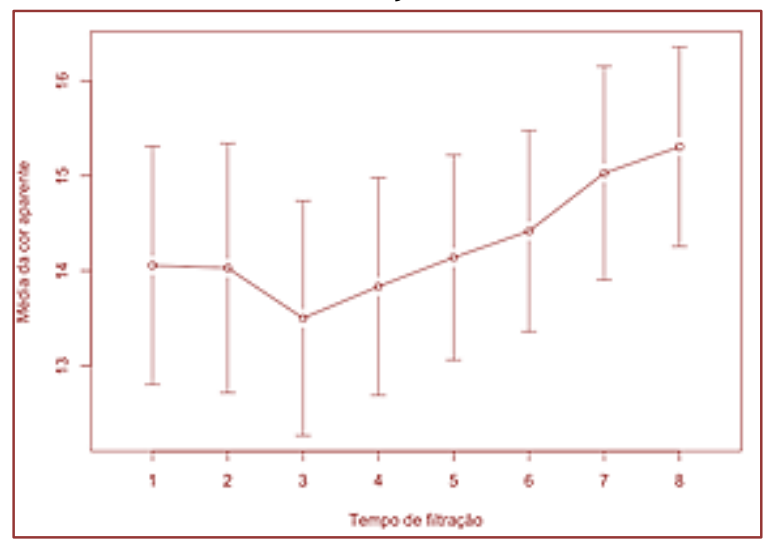

Para o parâmetro de cor verdadeira, observa-se na Tabela 7, que somente na parcela o efeito principal taxa de filtração foi estatisticamente significativos. Nota-se na Figura 6, que as taxas de filtração estudadas apresentaram comportamentos diferentes. 0 valor médio mais alto foi obtido para a taxa de filtração de $253 \mathrm{~m}^{3} / \mathrm{m}^{2}$.dia, enquanto o menor valor foi obtido para a taxa de filtração de $280 \mathrm{~m}^{3} / \mathrm{m}^{2}$.dia. Tal comportamento se assemelha ao comportamento obtido para a cor aparente. 
Figura 6 - Gráficos que relacionam os níveis das taxas de filtração com o valor médio da cor verdadeira.

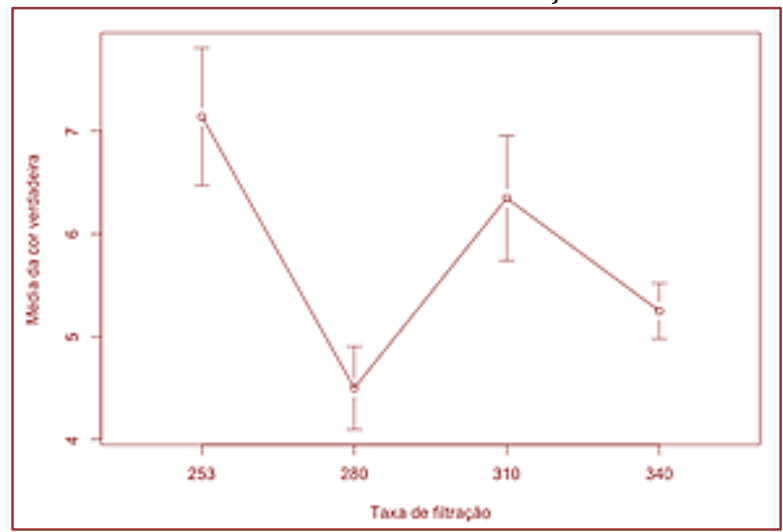

Na análise do parâmetro de absorbância (Tabela 7), nota-se que na parcela, o efeito principal taxa de filtração e que na sub-parcela, o efeito principal tempo de filtração foram estatisticamente significativos. Na Figura 7 (a) observa-se um comportamento semelhante ao obtido para a cor aparente, enquanto na Figura 7 (b), nota-se, um comportamento semelhante ao comportamento obtido para a cor aparente e verdadeira, indicando que a taxa de filtração é a taxa de $280 \mathrm{~m}^{3} / \mathrm{m}^{2}$.dia foi a que obteve maior redução de espécies que dão coloração a água.

Figura 7- (a) Gráfico da relação entre as médias da absorbância (ABS) em função do tempo de filtração; (b) Gráfico da relação entre as médias da absorbância (ABS) em função da taxa de filtração.

a)

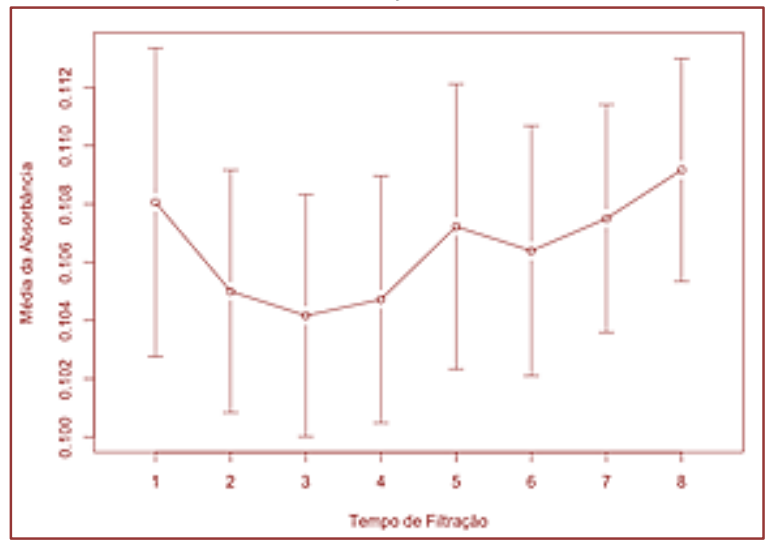

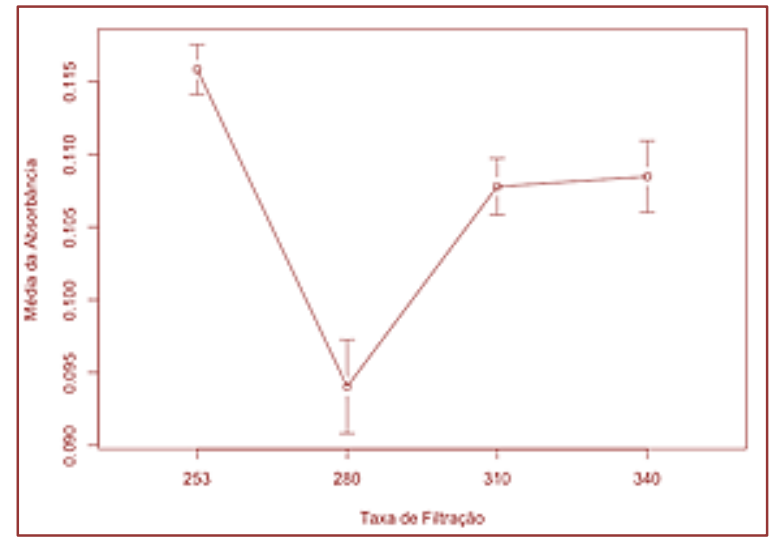

Para o parâmetro de pH, somente a relação de segunda ordem entre tempo de filtração e taxa de filtração foi significativa (Tabela 7). Nota-se (Figura 8), uma variação significativa no comportamento das curvas para todas as taxas estudadas. Contudo, a variação dos valores é pequena, segundo Pavanelli (2001 apud Lima, 2019), devido o coagulante hidroxicloreto de alumínio apresenta pouca variação no pH do meio, ocasionado pela hidrolise do hidroxicloreto que libera poucos íons $\mathrm{H}+$ no meio quando comparado a outros coagulantes, como o cloreto de alumínio, sulfato de alumínio e cloreto férrico. 
Figura 8 - Gráfico da interação entre tempo de filtração e taxa de filtração para o pH.

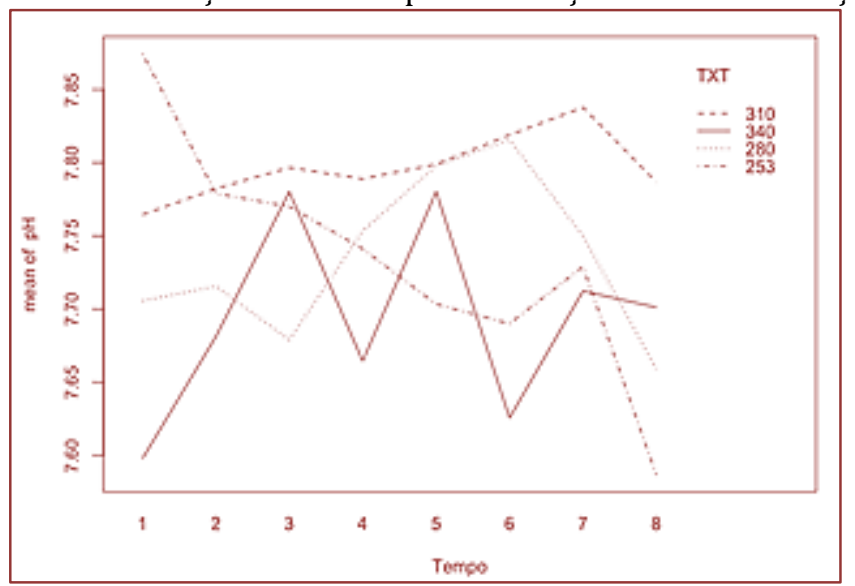

A Figura 9 apresenta os gráficos de resíduos dos resultados da análise de pH. Observa-se que grande parte dos resultados aparecem aleatoriamente espalhados em ambos os lados de zero (Figura 9 (a) e (d)), como também, de estão espalhados de forma aleatória em relação a curva na Figura 9 (c) e que os resultados seguem uma distribuição normal devido os pontos se aproximarem de uma linha reta (Figura 9 (b)).

Figura 9 - Gráficos de resíduos para a variável resposta pH. (a) Gráfico de resíduos em função dos valores ajustados; (b) Gráfico de probabilidade normal; (c) Gráfico de resíduos padronizados em função dos

a) valores ajustados; e (d) Gráfico de resíduos padronizados em função dos níveis dos fatores.

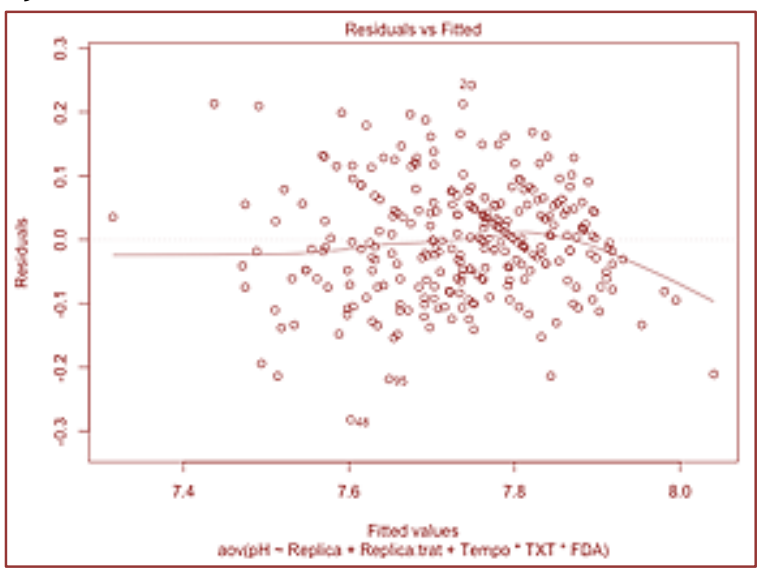

c)

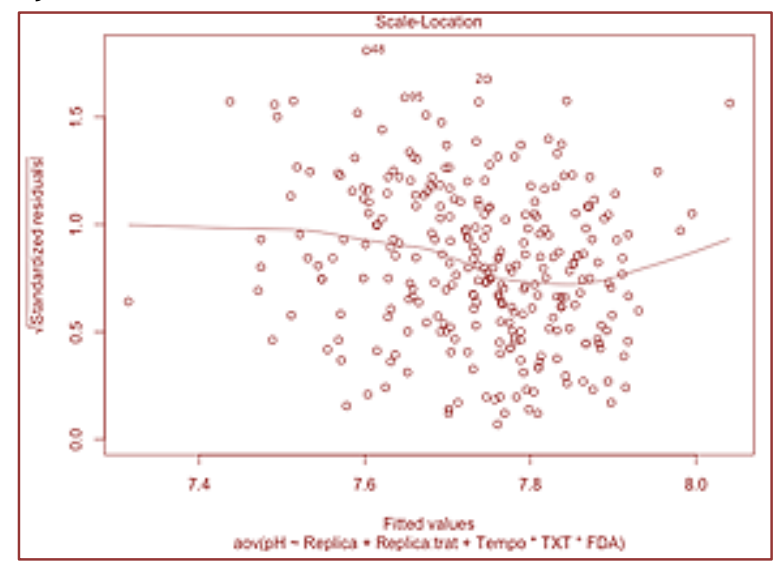

b)

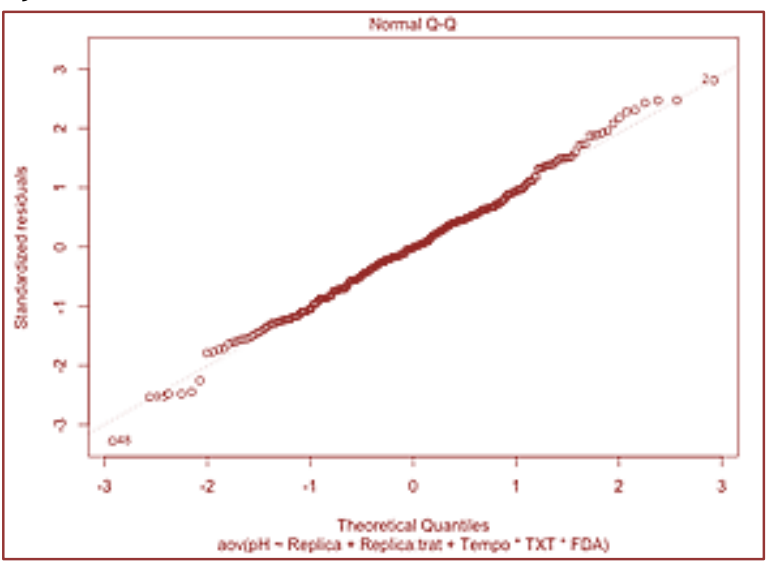

d)

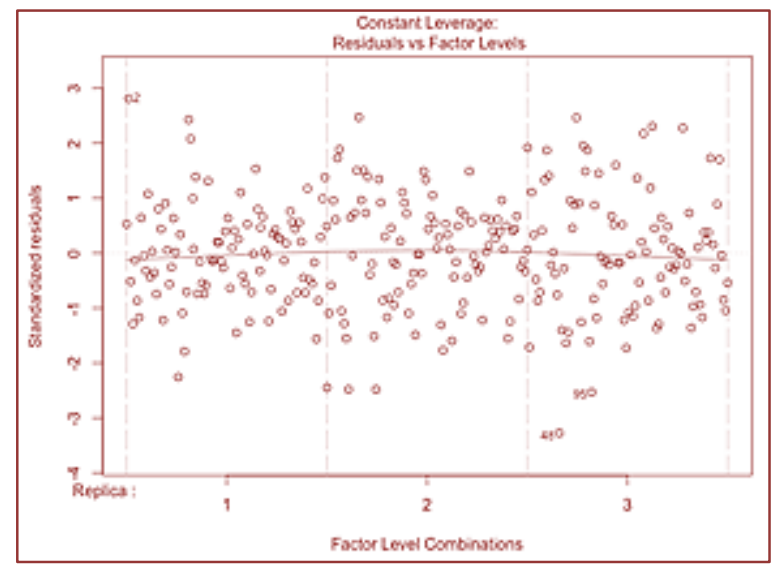




\subsection{AVALIAÇÃO DA ROBUSTEZ DAS VARIÁVEIS DE CONTROLE PARA A DUPLA FILTRAÇÃO}

Com o objetivo de avaliar a robustez e encontrar a condição menos sensível a variações nos experimentos, foram avaliados para cada variável resposta quais os efeitos e interações foram significativas, considerando o tempo de filtração como um fator de ruído e para um valor de p menor que $0,05(\alpha=5 \%)$. A Tabela 8 apresenta os resultados do valor de P obtidos para os efeitos principais e de interação de cada parâmetro analisado.

Na Tabela 8, observa-se que para o parâmetro pH os efeitos principais e os efeitos de interação não apresentaram significância estatística, pois os valores de P estão acima de 0,05 . Isto indica que os níveis dos fatores estudados não influenciaram nos resultados do $\mathrm{pH}$ da água tratada.

Tabela 8 - Valores de P do planejamento Split-splitplot para a dupla filtração

\begin{tabular}{|c|l|c|c|c|c|c|}
\hline \multicolumn{2}{|c}{ Fonte de Variação } & Turbidez & Cor Aparente & Cor Verdadeira & ABS \\
\hline \multirow{3}{*}{ Parcela } & Replica & 0,12328 & 0,9400052 & 0,03747 & 0,04698 & 0,7124 \\
\cline { 2 - 7 } & dummy & 0,06705 & 0,15835 & 0,01414 & 0,0752 & 0,3767 \\
\hline \multirow{3}{*}{ Subparcela } & FDA & 0,04587 & 0,0001274 & 0,34431 & 0,79049 & 0,6222 \\
\cline { 2 - 7 } & Dummy:FDA & 0,39463 & 0,2576718 & 0,37667 & 0,82172 & 0,3878 \\
\hline \multirow{3}{*}{$\begin{array}{c}\text { Sub- } \\
\text { subparcela }\end{array}$} & Tempo & $5,462 \times 10^{-6}$ & 0,0005376 & $4,417 \times 10-8$ & $6,50 \times 10-13$ & 0,3252 \\
\cline { 2 - 7 } & Tempo:dummy & $3,521 \times 10^{-7}$ & $5,451 \times 10-7$ & 0,05518 & $2,854 \times 10-12$ & 0,1156 \\
\cline { 2 - 7 } & Tempo:FDA & 0,55950 & 0,4960700 & 0,24416 & 0,99865 & 0,3870 \\
\cline { 2 - 7 } & Tempo:dummy:FDA & 1,00000 & 0,9999994 & 0,98888 & 1,00000 & 0,6888 \\
\hline & \multicolumn{2}{|c|}{ TXT - Taxa de Filtração; FDA - Filtro descendente de areia; Tempo - tempo da carreira de filtração } \\
\hline
\end{tabular}

Para o parâmetro da Turbidez (Tabela 8), nota-se que o efeito principal da granulometria FDA na subparcela foi significativo e que o efeito principal do tempo de filtração e a interação de segunda ordem entre tempo de filtração e a relação entre a taxa de filtração e a granulometria do FAP foram significativos na influência dos resultados.

Na Figura 10 (a), percebe-se que os intervalos e confiança se sobrepõem, indicando que não a uma diferença significativa entre os valores. Já na Figura 4.13 (b), nota-se que das condições estudadas, a que apresentou menor variação na média dos valores da turbidez no decorrer do tempo de filtração foi a relação dummy de número 6, que corresponde ao filtro ascendente FAP 2 com taxa de filtração de 280 $\mathrm{m}^{3} / \mathrm{m}^{2}$.dia. Está condição apresentou valores médios baixos para turbidez, estando próximo de 1,00. Contudo, observa-se nas Figuras 10 (a) e (b), que a média dos valores de turbidez estão acima do valor permitido pela Portaria da Consolidação n ${ }^{5} / 2017$ (Brasil, 2017).

Figura 10 - (a) Gráfico do valor médio da turbidez em função da granulometria dos FDAs; (b) em função da interação entre o tempo de filtração e a relação entre taxa de filtração e granulometria dos FAP.

a)

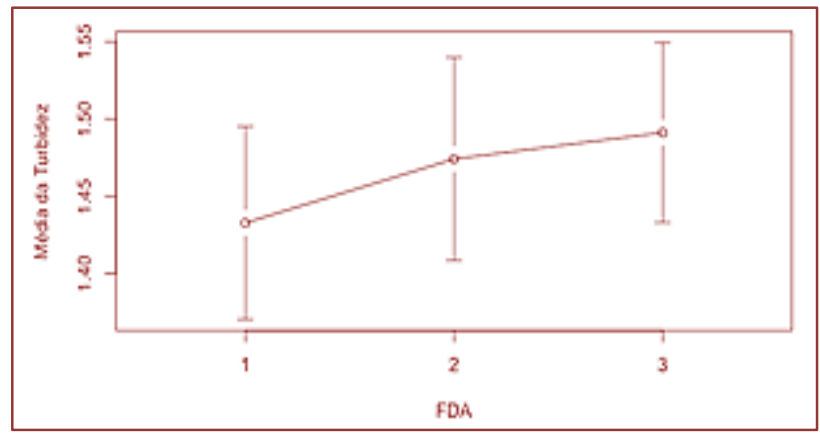

b)

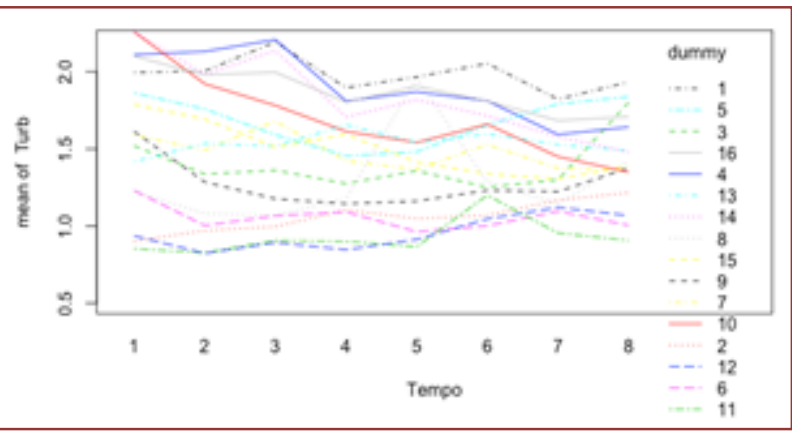


A Figura 11, apresenta os gráficos referentes a analise de resíduo para o parâmetro da turbidez. Observase, que grande parte dos resultados aparecem aleatoriamente espalhados em ambos os lados de zero com baixa dispersão (Figura 11 (a) e (d)), como também, de estão espalhados de forma aleatória em relação a curva na Figura 11 (c) e que os resultados seguem uma distribuição normal devido os pontos se aproximarem de uma linha reta (Figura $11(\mathrm{~b})$ ).

Figura 11 - Gráfico da media dos resultados da turbidez (a) em função da granulometria do filtro descendente de areia e (b) em função da interação entre o tempo de filtração e a relação entre taxa de

a)

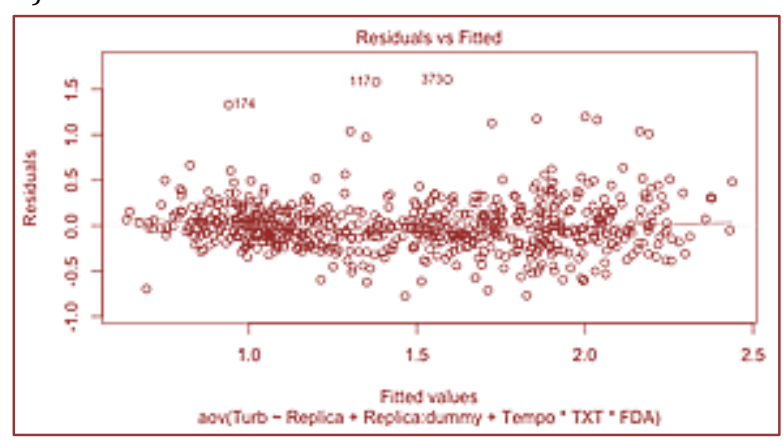

c)

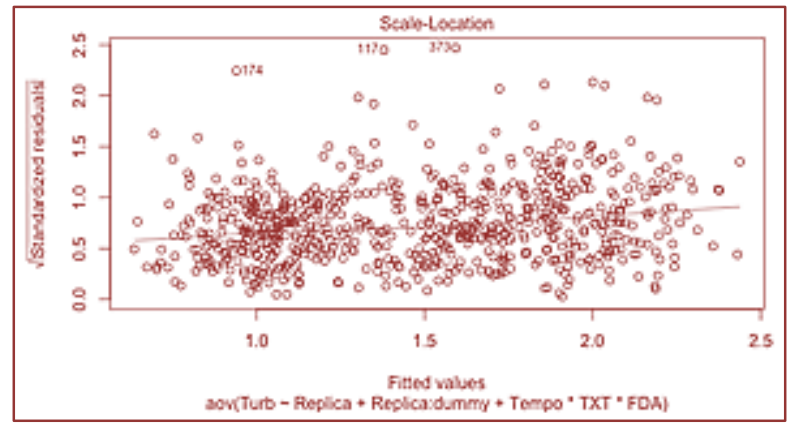

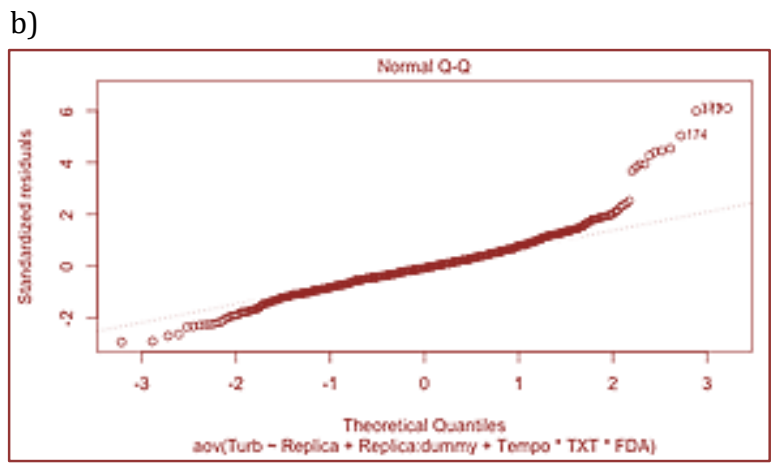

d)

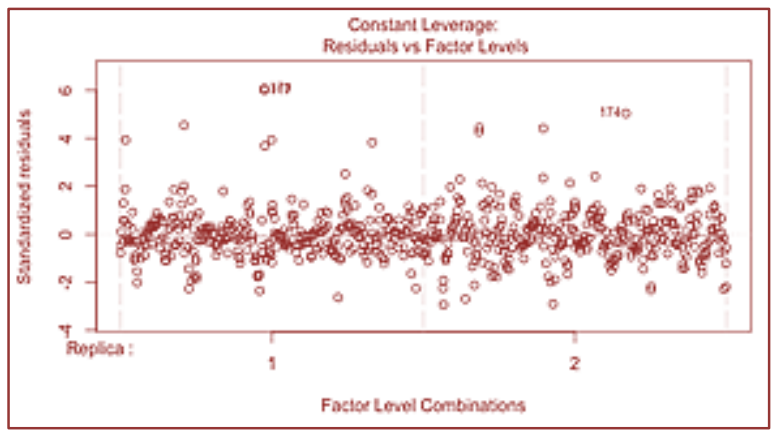

Na Tabela 8, avaliando o valor de P para o parâmetro cor aparente, nota-se que os efeitos principais da granulometria FDA e tempo de filtração e a interação de segunda ordem entre taxa de filtração e tempo de filtração foram significativos na influência dos resultados.

Na Figura 12 (a), nota-se que o maior valor da média para os resultados da cor aparente ocorreu para o filtro FDA 3 (filtro de maior granulometria). Para os filtros 1 e 2, não há uma diferença significativa entre seus valores médios, indicando que ambas as granulometrias apresentaram comportamento semelhante, obtendo valores em conformidade com a Portaria da Consolidação n 5/2017 (Brasil, 2017).

Observa-se, que as condições que apresentaram as menores variações nos valores médios da cor aparente correspondem aos dummy de números 4 e 16, ambos com taxas de filtração de $340 \mathrm{~m}^{3} / \mathrm{m}^{2}$.dia, porém com filtros ascendentes diferentes, estando o dummy 4 relacionado ao FAP 1 e o dummy 16 relacionado ao FAP 4. Contudo, ambas as condições apresentaram valores médios de cor aparente acima do valor permitido pela Portaria da Consolidação $n^{\circ} 5 / 2017$ (Brasil, 2017). A condição que apresentou o menor resultado para a média da cor aparente em função do tempo de filtração, foi o dummy de número 12, que corresponde ao FAP 3 com taxa de filtração de $340 \mathrm{~m}^{3} / \mathrm{m}^{2}$.dia, com uma variação ligeiramente maior do que as condições de dummy 4 e 16. Com isso, tem-se que a taxa de filtração de $340 \mathrm{~m}^{3} / \mathrm{m}^{2}$.dia, foi a que apresentou menor sensibilidade com o tempo de filtração estudado, tendo o FAP 3 apresentando melhor influencia no resultado da cor aparente final do processo. 
Figura 12 - Gráfico da media dos resultados da cor aparente (a) em função da granulometria do filtro descendente de areia e (b) em função da interação entre o tempo de filtração e a relação entre taxa de

a)

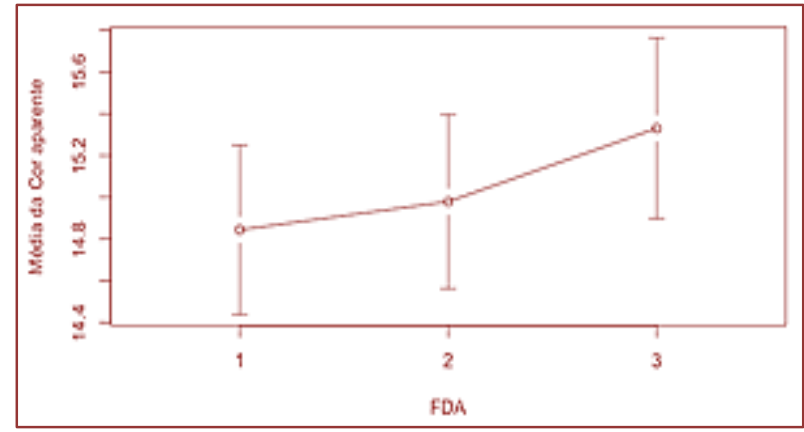

b)

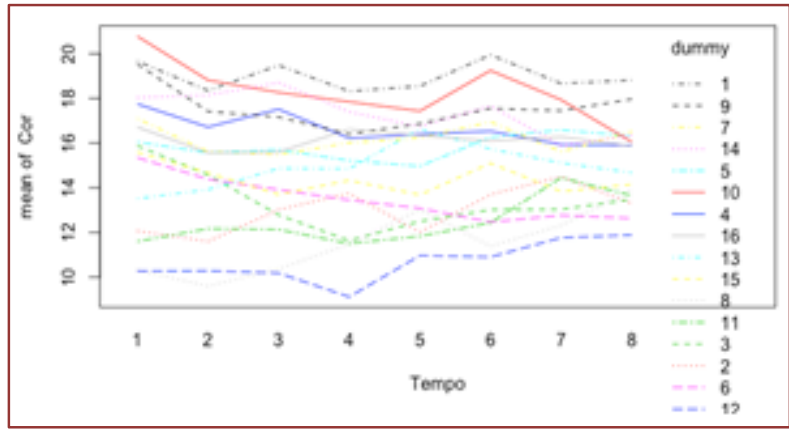

A Figura 13, apresenta os gráficos referentes a analise de resíduo, afim de verificar se o modelo é adequado ou não para o parâmetro de cor aparente. Observa-se, na Figura 13, que grande parte dos resultados aparecem aleatoriamente espalhados em ambos os lados de zero com baixa dispersão (Figura 13 (a) e (d)), como também, de estão espalhados de forma aleatória em relação a curva na Figura 13 (c) e que os resultados seguem uma distribuição normal devido os pontos se aproximarem de uma linha reta (Figura 13 (b)).

Figura 13 - Gráficos de resíduos para a variável resposta cor aparente. (a) em função dos valores ajustados; (b) de probabilidade normal; (c) padronizados em função dos valores ajustados; e (d) padronizados em função dos níveis dos fatores.

a)

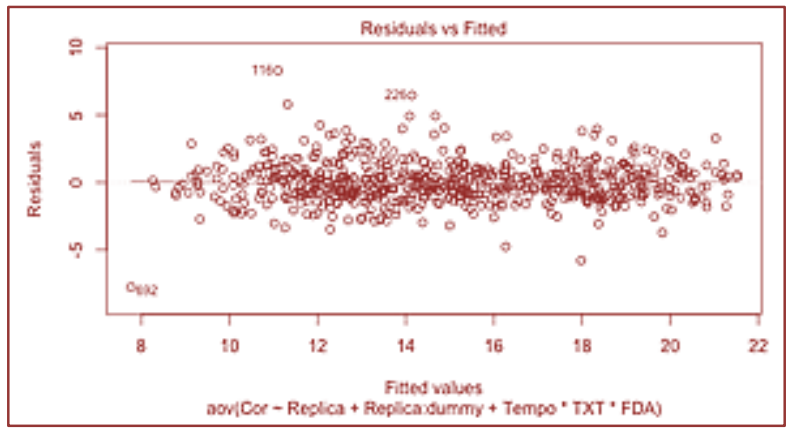

c)

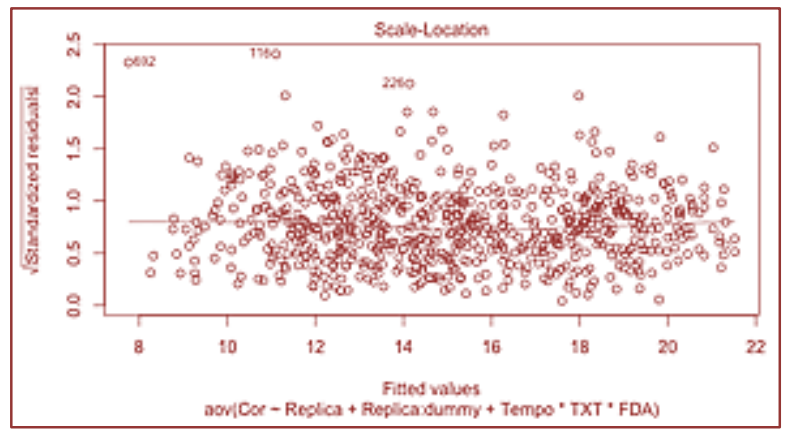

b)

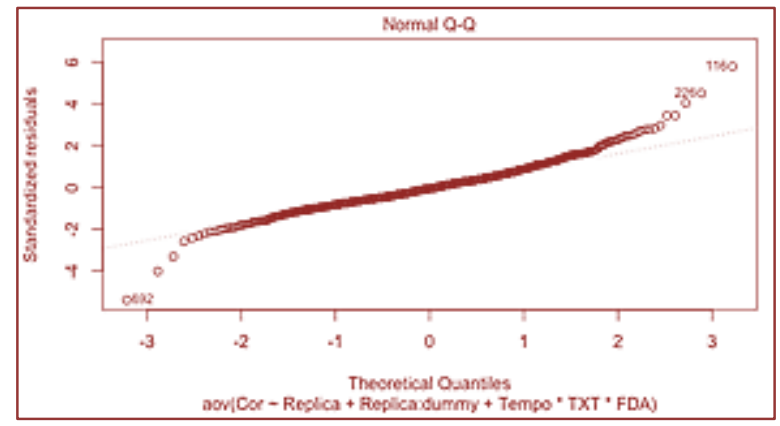

d)

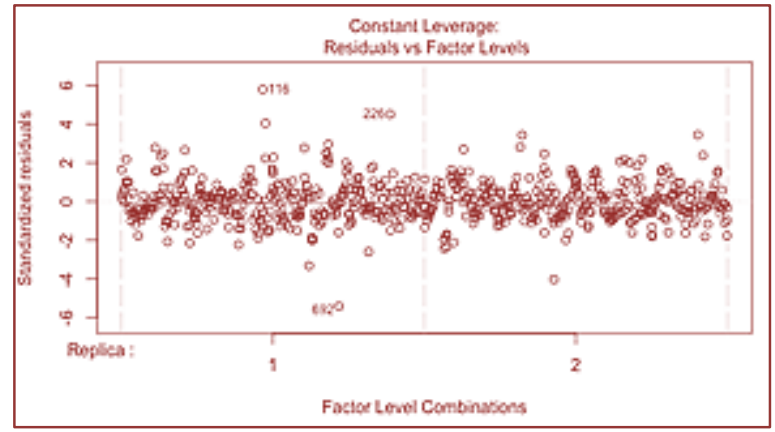

Para o parâmetro de cor verdadeira (Tabela 8) nota-se que na parcela principal o efeito correspondente a relação entre a granulometria do FAP e a taxa de filtração e que na sub-subparcela o tempo de filtração foram significativos na influência dos resultados obtidos. Porém, se aumentamos o valor de alfa para 6\%, será possível incluir a interação entre o tempo de filtração e a relação entre taxa de filtração e a 
granulometria do filtro ascendente FAP, como estatisticamente significantes na influência nos resultados da cor verdadeira.

A Figura 14 (a) observa-se que os menores valores médios foram obtidos para a relação dummy 11 e 12 , que corresponde ao filtro ascendente FAP 3 e as taxas de filtração de 310 e $340 \mathrm{~m}^{3} / \mathrm{m}^{2}$.dia, respectivamente. Já na Figura 14 (b), nota-se diversas condições que apresentaram pouca variação nos resultados da cor verdadeira ao longo de tempo de filtração, tais como as curvas 2, 5, 11 e 12, tendo as curvas de número 11 e 12, apresentando as menores variações nos valores para a cor verdadeira.

Figura 14 - Gráfico da média dos resultados da cor verdadeira (a) em função da interação entre a relação entre a granulometria do FAP e a taxa de filtração (b) em função da interação entre o tempo de filtração e

a)

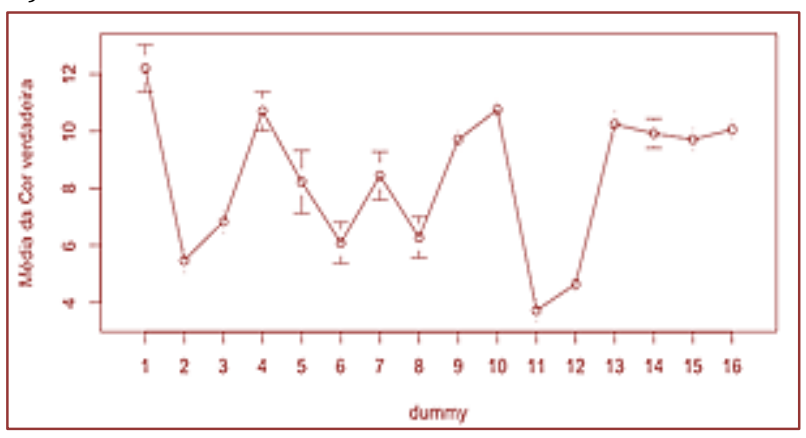

b)

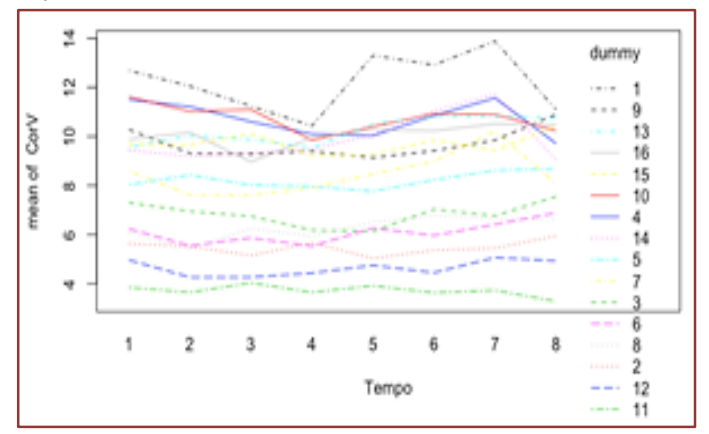

Na Figura 15, mostra os gráficos referentes a analise de resíduo, a fim de verificar se o modelo é adequado ou não para o parâmetro de cor verdadeira. Nota-se que grande parte dos resultados aparecem aleatoriamente espalhados em ambos os lados de zero com baixa dispersão (Figura 15 (a) e (d)), como também, de estão espalhados de forma aleatória em relação a curva na Figura 15 (c) e que os resultados seguem uma distribuição normal devido os pontos se aproximarem de uma linha reta (Figura 15 (b)).

Figura 15 - Gráficos de resíduos para a variável resposta cor verdadeira. (a) em função dos valores ajustados; (b) de probabilidade normal; (c) padronizados em função dos valores ajustados; e (d) padronizados em função dos níveis dos fatores.

a)
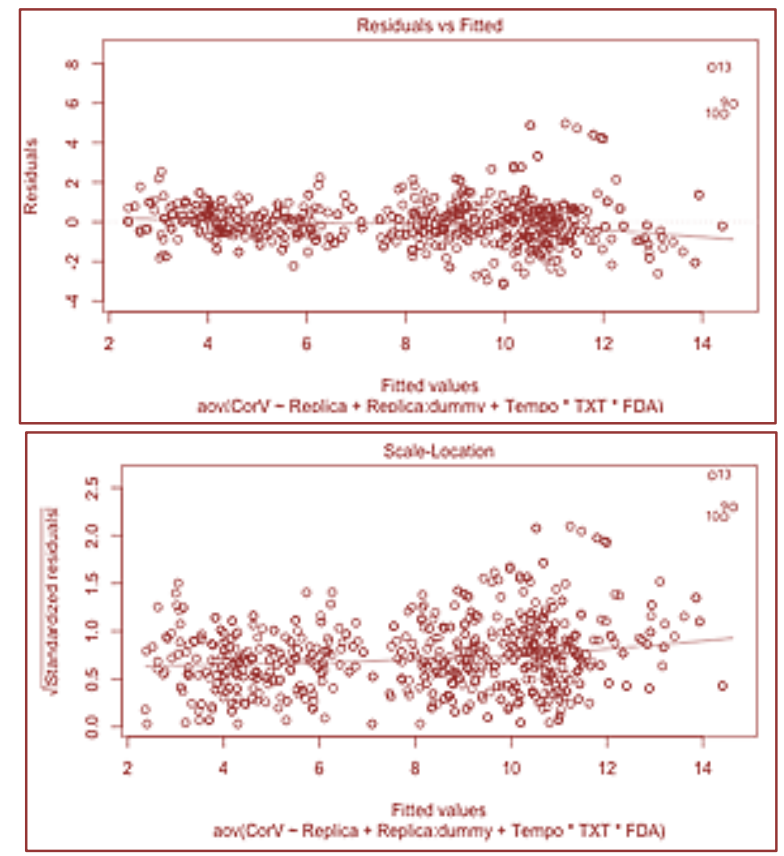

c) b)

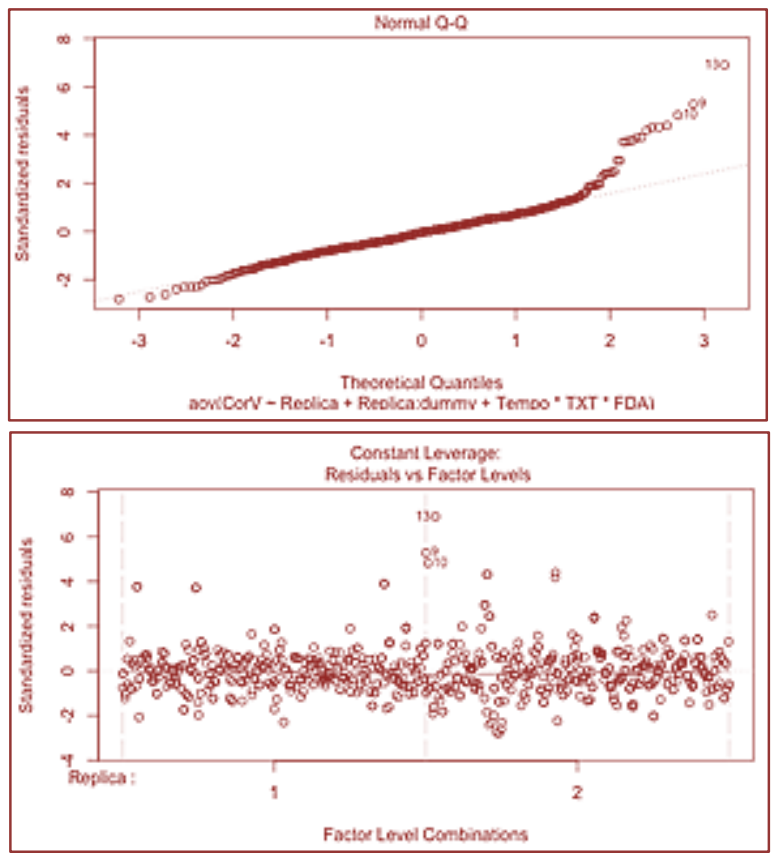

d) 
No parâmetro da absorbância observa-se que na sub-subparcela o efeito principal correspondendo ao tempo de filtração e a interação de segunda ordem entre o tempo de filtração e a relação da granulometria do filtro FAP e a taxa de filtração foram significativos, para valores P abaixo de 0,05 ( $\alpha=5 \%$ ). Porém, para um $\alpha$ de $10 \%$, na parcela principal o efeito da relação da granulometria do filtro FAP e a taxa de filtração foi significativo na influência dos resultados da absorvância.

A Figura 16 (a) apresenta o gráfico da média da absorbância em função da relação da granulometria do FAP e da taxa de filtração. Percebe-se que o menor valor médio para a abosrbância ocorreu para o filtro ascendente FAP 1 com taxa de filtração de $280 \mathrm{~m}^{3} / \mathrm{m}^{2}$.dia (dummy 2), seguido pelos pontos 6 (FAP 2, taxa de filtração $280 \mathrm{~m}^{3} / \mathrm{m}^{2}$.dia), 8 (FAP 2, taxa de filtração $340 \mathrm{~m}^{3} / \mathrm{m}^{2}$.dia), 11 (FAP 3, taxa de filtração 310 $\mathrm{m}^{3} / \mathrm{m}^{2}$.dia) e 12 (FAP 3, taxa de filtração $340 \mathrm{~m}^{3} / \mathrm{m}^{2}$.dia), que devido a sobreposição dos intervalos de confiança não apresentam diferenças significativas entre si. Enquanto, o FAP 4 apresentou valores médio de abosrbância elevados para as quatro taxas de filtração estudadas. Com isso, os FAP 2 e 3 apresentaram comportamento semelhantes para taxas mais elevadas.

Figura 16 - Gráfico da média da absorbância em função da relação entre a granulometria do FAP e a taxa de filtração (b) em função da interação entre o tempo de filtração e a relação da granulometria do filtro FAP e a taxa de filtração foram significativos.

a)

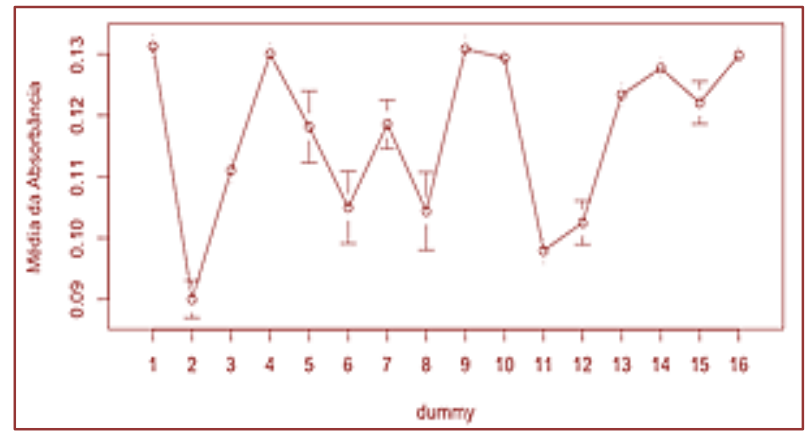

b)

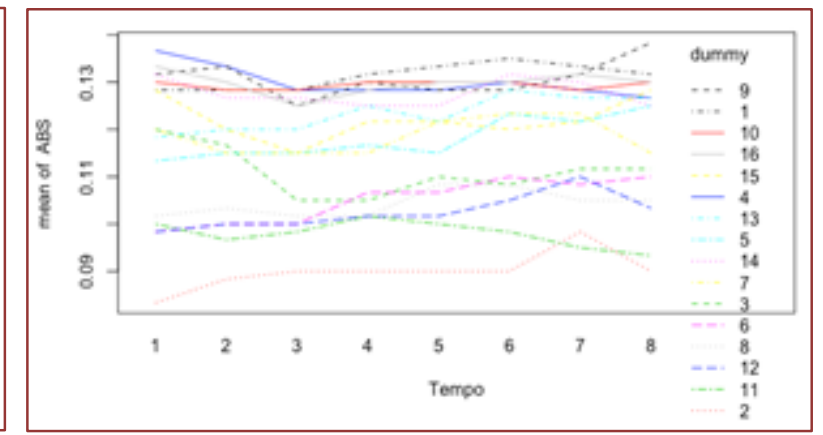

Na Figura 16 (b), observa-se que as curvas com menores variações no valor da média da absorbância ao longo do tempo de filtração foram as curvas 10 e 11, que correspondem ao filtro FAP 3 com taxas de filtração de 280 e $310 \mathrm{~m}^{3} / \mathrm{m}^{2}$.dia, respectivamente. Contudo, a curva 11 (FAP 3, taxa de filtração de 310 $\mathrm{m}^{3} / \mathrm{m}^{2}$.dia) apresentou o menor valor médio da absorbância ao longo das 8 horas da carreira de filtração. Tal comportamento é semelhante ao observado nos parâmetros de cor aparente e cor verdadeira, indicando que a melhor remoção de substâncias orgânicas dissolvidas ocorreram na taxa de filtração foi a de $310 \mathrm{~m}^{3} / \mathrm{m}^{2}$.dia com o filtro FAP 3 .

Na Figura 17, mostra-se os gráficos referentes a analise de resíduo para o parâmetro da absorbância. Nota-se que os resultados estão aleatoriamente espalhados em ambos os lados de zero com baixa dispersão (Figura 17 (a) e (d)), como também, os resultados estão espalhados de forma aleatória em relação a curva na Figura 17 (c) e que seguem uma distribuição normal devido os pontos se aproximarem de uma linha reta (Figura 17 (b)). 
Figura 17 - Gráficos de resíduos para a variável resposta absorbância. (a) em função dos valores ajustados; (b) de probabilidade normal; (c) padronizados em função dos valores ajustados; e (d) padronizados em função dos níveis dos fatores.

a)

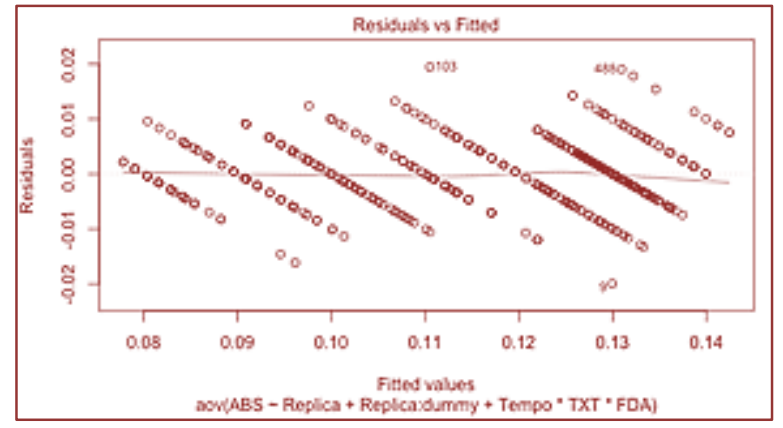

c)

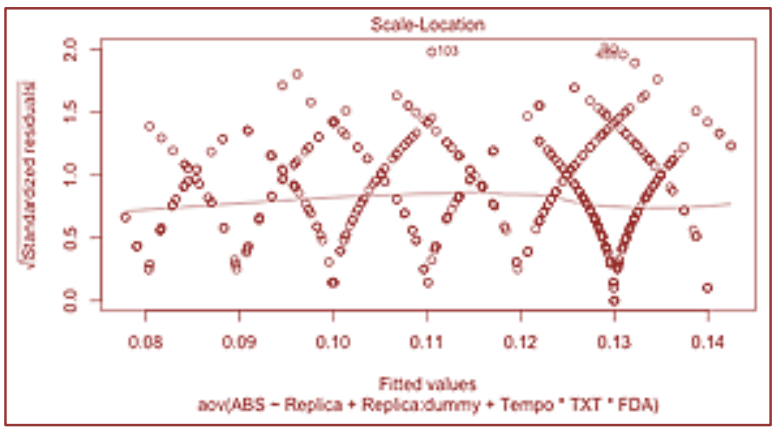

b)

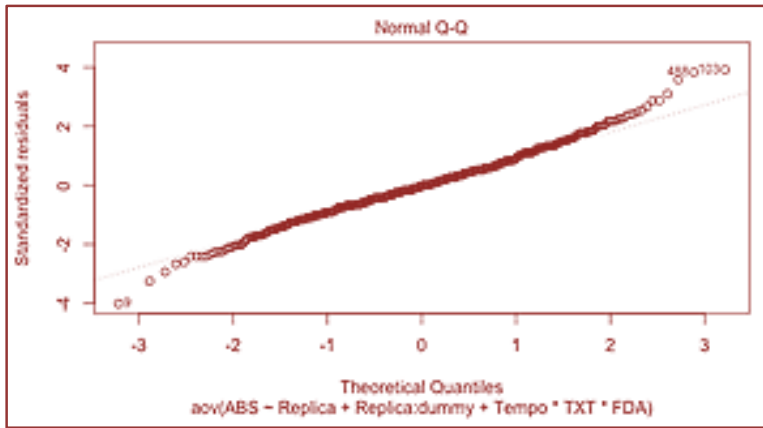

d)

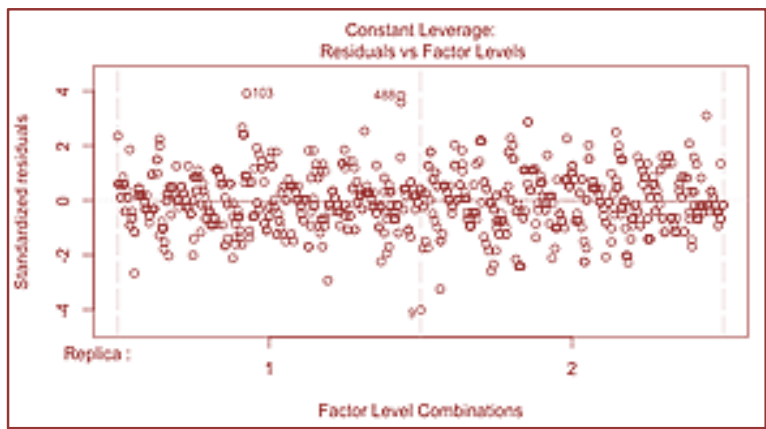

\section{CONCLUSÕES}

No presente estudo a água bruta da lagoa de extremoz/RN, foi caracterizada como sendo de baixa turbidez, cor elevada e pH levemente alcalino, enfatizando que as águas brutas utilizadas para o tratamento nas duas configurações apresentaram características semelhantes, sem sofrer alterações buscas no ambiente.

Nas duas configurações estudadas tem-se que os níveis dos fatores de controle estudados influenciaram nos resultados obtidos para os parâmetros estudados e o fator de ruído tempo de filtração apresentou ser uma variável importante, pois, também, influenciou os resultados de diversos parâmetros.

Para as duas configurações estudadas não foram obtidos valores, para o parâmetro de turbidez, em conformidade com legislação. Porém, no caso do parâmetro da cor aparente, ambas as configurações obtiveram valores em conformidade com legislação.

Portanto, para os níveis dos fatores estudados o uso do filtro ascendente não aumentou a eficiência no processo. Contudo permitiu a utilização de taxa mais elevadas e com isso, sugere-se que novos estudos sejam utilizando taxas de filtração entre 280 e $340 \mathrm{~m}^{3} / \mathrm{m}^{2}$.dia e granulometria dos filtros descendentes de areia menores que $\mathrm{D}_{10}$ igual a 0,87 e com os filtros ascendentes com as características dos FAP 1 , FAP 2 e FAP 3. 0 FAP 4, que possui a menor granulometria entre os filtros ascendentes não apresentou bons resultados. Como também, sugere-se adicionar o processo de adsorção a estação piloto para buscar aumentar a remoção de substância orgânicas dissolvidas, que dão coloração a água, uma vez que, a presença de destas substâncias na etapa de desinfecção com cloro pode gerar subprodutos da cloração ideados, como os trihalometanos, como também, aumentar a remoção de turbidez.

O método estatístico split-plot apresentou ser uma ferramenta importante para identificar as condições mais robustez do processo, de modo que, o fator tempo de filtração, antes não levado em consideração em trabalhos anteriores sobre a estação piloto, se mostrou um fator importante a ser considerado influenciando nos resultados. Com isso, foi possível verificar a existência de condições dos fatores de controle com baixa variação no seu comportamento durante a realização dos ensaios. 


\section{REFERÊNCIAS}

[1] Apha, Standard Methods for the examination of water and wasterwater, American Public Health Association, Americam Water Works Association, Water Environmental Federation, 20 ${ }^{\text {th }}$ ed. Washinton, 2012;

[2] Brasil, Ministério da Saúde (BR/MS). Consolidação das normas sobre as ações e os serviços de saúde do Sistema Único de Saúde. Portaria de consolidação no 5/2017. Brasília: MS, 2017.

[3] Di Bernardo, L. e Dantas, A. DI B., Métodos e técnicas de tratamento de água, 2º edição, São Carlos, RiMa, 2005;

[4] Duarte, M. A. C., Tratamento de água para consume humano de reservatório eutrofizado através de pré e interoxidação, adsorção em carvão ativado e dupla filtração. Tese (Doutorado - Programa de Pós-graduação e Área de Concentração em Engenharia Hidráulica e Saneamento) - Escola de Engenharia de São Carlos da Universidade de São Paulo, 2011;

[5] Duarte, G. M. C., Simulação em instalação piloto da adequação de eta convencional para dupla filtração, Dissertação de mestrado, Programa de Pós-graduação em Engenharia Sanitária, Universidade Federal do Rio Grande do Norte, Natal, 2018.

[6] Freitas, A. P. B. R. de, Aplicação do método estatístico de Taguchi no estudo dos Processos Oxidativos Avançados $\left(\mathrm{Fe}^{+2} / \mathrm{H}_{2} \mathrm{O}_{2} / \mathrm{O}_{3} / \mathrm{UV}\right)$ no pré-tratamento de efluentes fenólicos, Dissertação de mestrado, USP, São Paulo, 2012;

[7] Lima, J. K. L, Avaliação da filtração direta descendente no tratamento de água de manancial com baixa turgidez e cor elevada, Dissertação de mestrado, Instituto Federal do Rio Grande do Norte, Mestrado Profissional em Uso Sustentável de Recursos Naturais, Natal, 2019;

[8] Machado, B. M., Potabilização de água com elevada densidade de cianobacterias e microalgas através de Sistema de dupla filtração em meio granular utilizando filtro de lavagem contínua. Tese (Doutorado - Programa de Pós-graduação Engenharia Ambiental) -Universidade de Santa Catarina, 2011.

[9] Merten, G. H.; Minella, J. P., Qualidade da água em bacias hidrograficas rurais: um desafio atual para a sobrevivencia futura, Agroecol. e Desenvol. Rur. Sustent. Porto Alegre, v.3, n.4, out/dez, 2002;

[10] Richter, C.A., Água: Métodos e tecnologia de tratamento, 5ำ reimpressão, São Paulo, Blucher, 2017;

Silva, G.G.; Naval, L.P.; Di Bernardo, L.; Dantas, A. DI B., Tratamento de água de reservatório por dupla filtração, oxidação e adsorção em carvão ativado granular, Eng Sanit Ambient, v.17, n.1,71-80, jan/mar, 2012. 


\section{Capítulo 16}

Determinação da concentração dos metais $\mathrm{Al}$, Cr e $\mathrm{Ni}$ em amostras de açaí (Euterpe Oleracea) do Rio Murucupi em Barcarena (Pará, Brasil)

\section{Lucas Botelho Jerônimo}

Cibele Cintia Lopes Pires

Marcia Lídia Bastos da Silva

Charles Miller de Souza Borges

Alexsandro Sozar Martins

Kelly das Graças Fernandes Dantas

Bianca Silva da Fonseca Alves

Resumo: $\mathrm{O}$ objetivo desse estudo foi determinar os teores de $\mathrm{Al}, \mathrm{Cr}$ e $\mathrm{Ni}$ em amostras do fruto da espécie Euterpe oleracea (açaí) coletadas ao longo do Rio Murucupi, localizado na cidade de Barcarena no estado do Pará(Brasil) e comparar os resultados obtidos com dados da literatura. Foram coletadas amostras de seis pontos distintos próximos ao rio e igarapés da região. As amostras foram despolpadas, liofilizadas e em seguida submetidas à digestão ácida. A determinação das concentrações dos metais foi realizada usando um espectrômetro de emissão óptica com plasma induzido por micro-ondas (MIP OES). As concentrações de $\mathrm{Al}$ obtidas foram menores se comparadas a estudos realizados com as folhas e maiores em relação as pesquisas elaboradas com a polpa dessa espécie. Os resultados para Ni estão próximos aos valores consultados na literatura científica. Os teores de $\mathrm{Cr}$ estão acima dos valores definidos pela ANVISA. A contaminação do rio Murucupi com esgoto doméstico e vazamentos de rejeitos industriais pode ser a causa da presença elevada de $\mathrm{Al}$ e $\mathrm{Cr}$ nas amostras analisadas, porém é necessário acompanhar de que forma a presença desses metais no açaí (Euterpe oleracea) podem afetar a saúde da espécie e da população local.

Palavras Chave: Bioindicadores. Euterpe Oleracea. Metais 


\section{INTRODUÇÃO}

Por se tratar de uma região na qual o beneficiamento de minério (caulim e bauxita) é uma das principais atividades industriais, o município de Barcarena (Pará, Brasil) é suscetível a sofrer com impactos ambientais. Além dos vazamentos de rejeitos industriais, o município também é alvo do despejo de resíduos domésticos, pois ele não possui Estação de Tratamento de Esgoto, fatos que corroboram com os inúmeros registros de contaminação nessa região, desde o ano de 2000 (Medeiros, 2017; MPE-Pa; MPF, 2015; Pereira et.al, 2007).

Foram detectados níveis elevados de metais nas análises de águas superficiais de localidades que fazem parte do percurso da bacia hidrográfica do Rio Murucupi. De acordo com estudos realizados, esse rio compreende uma área de $30 \mathrm{~km}^{2}$ com perímetro de $29 \mathrm{~km}^{2}$, que se estende no sentido Sudoeste a Nordeste, sendo essa área constituída por um canal principal que possui 30 igarapés (Silva, 2012). 0 Rio Murucupi localiza-se próximo a planta industrial do município de Barcarena e se situa na microrregião do baixo Tocantins fazendo parte da região metropolitana de Belém, as quais foram afetadas diretamente pelo transbordo de efluentes advindo do beneficiamento de bauxita (IEC a, 2018).

Uma das possibilidades de mensurar o impacto ambiental por causa de metais lançados na natureza é o uso do biomonitoramento, que consiste na utilização de organismos para verificar, avaliar e obter dados quantitativos dos efeitos das modificações na composição química, do ambiente, essencialmente com espécies nativas da região do estudo (Neves et al., 2016; Souza et al., 2018). A espécie Euterpe oleracea (açaí) é facilmente vista ao longo das margens do Rio Murucupi, devido se tratar de uma região de várzea, local onde a espécie vegetal é comumente encontrada (Menezes et al., 2008). Sendo de origem nativa da América Central e do Sul, é considerada a palmeira mais produtiva da região amazônica, se destacando por ter um fruto exótico, sendo consumido como um alimento básico nessa região do Brasil. Neves et al. (2016) utilizaram a espécie Euterpe oleracea Mart. como monitor biológico, por se tratar de uma planta fixa na qual permite uma avaliação mais precisa sobre uma área específica e encontraram concentrações significativas para os elementos Ca (cálcio), Mg (magnésio) e Al (alumínio).

Elementos como Al, $\mathrm{Cr}$ (cromo) e Ni (níquel) em excesso interferem no desenvolvimento de plantas, além de serem prejudiciais à saúde quando em excesso de disponibilidade. 0 cromo pode ocasionar dermatite alérgica, sangramento do trato gastrointestinal, câncer no aparelho respiratório e úlceras na pele. Ademais, danificar a membrana mucosa, fígado e danos aos rins (Ali; Alkhafajy, 2016). Outro elemento em discussão é o níquel, que em excesso, pode resultar em danos nos pulmões, fígado e rins. Em grandes quantidades, o Ni também pode causar câncer, insuficiência respiratória, defeitos congênitos, alergias, dermatite e insuficiência cardíaca. $\mathrm{O} \mathrm{Ni}$, assim como $\mathrm{Cu}$ (cobre) e $\mathrm{Zn}$ (zinco) são metais traço essenciais no corpo humano, mas se o corpo absorver $\mathrm{Cu}, \mathrm{Zn}$ e $\mathrm{Ni}$ excessivos do ambiente externo, eles prejudicarão a saúde humana (Ali; Alkhafajy, 2016). Em relação ao alumínio, sua toxicidade pode ocasionar função intelectual diminuída, esquecimentos, incapacidade de concentração, comprometimento de fala e da linguagem, alterações de personalidade (humor alterado, depressão, demência), alucinações visuais e/ou auditivas, distúrbios motores e convulsões epiléticas (Crisponi et al, 2013).

Diante do exposto, o objetivo desse estudo foi determinar os teores de $\mathrm{Al}, \mathrm{Cr}$ e $\mathrm{Ni}$ em amostra do fruto da espécie Euterpe oleracea Mart. coletadas ao longo do Rio Murucupi em Barcarena (Pará, Brasil) e comparar os resultados obtidos com dados encontrados na literatura.

\section{MATERIAIS E MÉTODOS}

As amostras de açaí (Euterpe oleracea) foram coletas em locais próximos ao Rio Murucupi e igarapés, no município de Barcarena, Estado do Pará, Brasil. Na Tabela 1 estão apresentados os locais e os pontos de coleta das amostras.

Tabela 1 - Pontos de coleta, bairro e localização das amostras de açaí.

\begin{tabular}{|c|c|c|}
\hline Pontos & Bairro & Localização \\
\hline P1 & Sítio São Lourenço - Barcarena & 1 $30^{\prime} 39^{\prime \prime} \mathrm{S} 48^{\circ} 40^{\prime} 04^{\prime \prime} \mathrm{W}$ \\
\hline P2 & Sítio São Lourenço - Barcarena & $1^{\circ} 30^{\prime} 39^{\prime \prime} \mathrm{S} 48^{\circ} 40^{\prime} 04^{\prime \prime} \mathrm{W}$ \\
\hline P3 & Murucupi - Barcarena & $1^{\circ} 31^{\prime} 25^{\prime \prime} \mathrm{S} 48^{\circ} 41^{\prime} 19^{\prime \prime} \mathrm{W}$ \\
\hline $\mathrm{P} 4$ & Comunidade Bom Futuro - Barcarena & 1 31'56" S 48 42' 45”'W \\
\hline P5 & Comunidade Bom Futuro - Barcarena & 10 31'56" S 48 42' 45”'W \\
\hline P6 & Comunidade Bom Futuro - Barcarena & 10 31' 54" S 48 42' 46" W \\
\hline
\end{tabular}


No total foram adquiridas seis amostras de açaí, que foram armazenadas em saco plástico (tipo zip lock) e encaminhadas para o Laboratório do Grupo de Espectrometria Analítica Aplicada (GEAAp) na Universidade Federal do Pará (Belém-Pará).

Os frutos de açaí foram lavados abundantemente com água destilada, armazenados em frascos volumétricos, congelados e posteriormente secos utilizando um liofilizador (L101, Liotop, São Carlos, Brasil). A secagem das amostras foi realizada utilizando o processo de liofilização, que durou aproximadamente 8 dias. Após a secagem, as amostras foram despolpadas e as polpas do açaí foram submetidas a digestão ácida.

$\mathrm{Na}$ etapa de digestão foi pesado aproximadamente $0,25 \mathrm{~g}$ da amostra liofilizada e adicionado $4 \mathrm{~mL}$ de ácido nítrico $\left(\mathrm{HNO}_{3}\right)$ e $4 \mathrm{~mL}$ de peróxido de hidrogênio $\left(\mathrm{H}_{2} \mathrm{O}_{2}\right)$. A digestão das amostras foi realizada utilizando um forno de micro-ondas com cavidade (Start E, Milestone, Sorisole, Itália) com a seguinte programação realizada em 3 etapas (potência, temperatura e tempo): $800 \mathrm{~W}, 200{ }^{\circ} \mathrm{C}, 10 \mathrm{~min} ; 800 \mathrm{~W}, 200$ o C, 15 min e ventilação por 50 min. Os digeridos foram transferidos para frascos volumétricos e aferidos com água desionizada para um volume final de $20 \mathrm{~mL}$. Os brancos analíticos foram preparados pelo mesmo procedimento, sem a adição de amostra.

Um espectrômetro de emissão óptica com plasma induzido por micro-ondas (MIP OES 4100, Agilent Technologies, Melbourne, Austrália) equipado com nebulizador OneNeb inerte e câmara de nebulização ciclônica tipo simples passo foi usado para determinar as concentrações de $\mathrm{Al}, \mathrm{Cr}$ e $\mathrm{Ni}$ nos digeridos de açaí coletados no Rio Murucupi. 0 N2 produzido por um gerador de nitrogênio foi utilizado para sustentar o plasma.

Todos os reagentes usados foram de grau analítico. Para o preparo das soluções foi utilizada água desionizada. Todas as vidrarias e materiais de polipropileno usados foram imersos em um banho de ácido nítrico $10 \%$ (v/v) durante $24 \mathrm{~h}$ e em seguida lavados abundantemente com água desionizada antes do uso.

\section{RESULTADOS E DISCUSSÃO}

Nas amostras de açaí (polpa) coletadas nos pontos P1, P2, P3, P4, P5 e P6, situadas às margens do Rio Murucupi, foram analisados $\mathrm{Al}, \mathrm{Cr}$ e Ni. A Tabela 2 apresenta a concentração desses metais encontrados nas amostras de açaí nos seis pontos de coleta.

Tabela 2 - Concentração de $\mathrm{Al}, \mathrm{Cr}$ e Ni (mg/kg) obtidos em amostras de açaí.

\begin{tabular}{|c|c|c|c|}
\hline Pontos & $\mathrm{Al}$ & $\mathrm{Cr}$ & $\mathrm{Ni}$ \\
\hline P1 & $32,07 \pm 4,09$ & $0,65 \pm 0,16$ & $3,98 \pm 0,37$ \\
\hline P2 & $7,28 \pm 0,47$ & $0,44 \pm 0,01$ & $1,51 \pm 0,11$ \\
\hline P3 & $16,06 \pm 1,72$ & $0,50 \pm 0,06$ & $0,45 \pm 0,07$ \\
\hline P4 & $9,48 \pm 1,61$ & $0,41 \pm 0,02$ & $0,55 \pm 0,01$ \\
\hline P5 & $20,91 \pm 0,88$ & $0,29 \pm 0,03$ & $0,57 \pm 0,03$ \\
\hline P6 & $7,23 \pm 0,21$ & $0,26 \pm 0,02$ & $0,52 \pm 0,00$ \\
\hline
\end{tabular}

O teor de Al variou entre os pontos de 7,23 a $32,07 \mathrm{mg} / \mathrm{kg}$. Em relação aos níveis de $\mathrm{Ni}$, a maior concentração foi encontrada na amostra de açaí no ponto P1 e o Cr apresentou concentração similar nas 6 amostras analisadas (variando de 0,26 a $0,65 \mathrm{mg} / \mathrm{kg}$ ). Os valores para Al foram menores, se comparados aos dados publicados por Neves et al. (2016), onde identificaram valores máximos e mínimos de 639,4 e $253,3 \mathrm{mg} / \mathrm{kg}$ de Al em folhas de açaizeiro coletados na região amazônica, respectivamente. As quantidades de Ni no P1 (3,98 mg/kg) quando comparada aos dados do mesmo autor $(1,36$ a $6,83 \mathrm{mg} / \mathrm{kg})$, estão próximo as concentrações obtidas neste estudo.

Menezes et al. (2008) estudaram constituintes inorgânicos em amostras de açaí liofilizado e obtiveram teores de $\mathrm{Al}$ e $\mathrm{Ni}$ de 0,36 e 0,28 mg/100 g, respectivamente. De acordo com esses resultados, os teores de Al nas amostras coletadas no Rio Murucupi estão elevados e os valores de Ni estão próximos nos dois estudos.

Entre os metais analisados foi encontrado referências de Ingestão Diária (ID) somente para Cr, em que Skalnaya e Skalny (2018) afirma que o teor de ID ideal de Cr varia de 50 a $200 \mu \mathrm{g} /$ dia e a resolução RDC no 269 (ANVISA, 2005) recomenda $35 \mu \mathrm{g} / \mathrm{dia}$ de Cr. Sendo assim, os resultados apresentados nesse estudo estão maiores do que o ID recomendado. Porém, de acordo com Skalnaya e Skalny (2018), as amostras de açaí não estão contaminadas e não geram efeitos tóxicos a saúde humana, pois tais efeitos somente são observados na ingestão de $1-5 \mathrm{~g}$ de $\mathrm{Cr}$. 
A contaminação do Rio Murucupi com esgoto doméstico e vazamentos de rejeitos industriais pode ser a causa da presença dos metais nas amostras analisadas. Dados do Instituto Evandro Chagas (IEC b, 2018) apontam a presença de alumínio, cromo e níquel no Rio Murucupi e em um de seus igarapés. Os valores identificados pelo IEC e os limites de contaminantes químicos inorgânicos definidos pela Resolução CONAMA № 357/2005 (CONAMA, 2005) em água doce estão demonstrados na Tabela 3.

Tabela 3 - Concentrações máximas de Al, Cr e Ni identificados pelo IEC no Rio Murucupi e no Igarapé Bom futuro e os limites máximos permitidos pelo CONAMA 357/2005

\begin{tabular}{|c|c|c|c|}
\hline Metal & Local & IEC & Limite \\
\hline Alumínio & Rio Murucupi & $2,4 \mathrm{mg} / \mathrm{L}$ & $0,1 \mathrm{mg} / \mathrm{L}$ \\
\hline Alumínio & Igarapé Bom Futuro & $2,5 \mathrm{mg} / \mathrm{L}$ & $0,1 \mathrm{mg} / \mathrm{L}$ \\
\hline Cromo & Rio Murucupi & $0,035 \mathrm{mg} / \mathrm{L}$ & $0,05 \mathrm{mg} / \mathrm{L}$ \\
\hline Cromo & Igarapé Bom Futuro & $0,002 \mathrm{mg} / \mathrm{L}$ & $0,05 \mathrm{mg} / \mathrm{L}$ \\
Níquel & Rio Murucupi & $0,009 \mathrm{mg} / \mathrm{L}$ & $0,025 \mathrm{mg} / \mathrm{L}$ \\
Níquel & Igarapé Bom Futuro & $0,001 \mathrm{mg} / \mathrm{L}$ & $0,025 \mathrm{mg} / \mathrm{L}$ \\
\hline
\end{tabular}

*Fonte: IEC b, 2018

**Fonte: Brasil, 2005

Considerando que as amostras de açaí foram coletadas ao longo do Rio Murucupi, Ramos e Geraldo (2007) afirma que a principal via de absorção de metais tóxicos pelas plantas é por meio das raízes e que as ações antrópicas sobre esses corpos hídricos pode ter influência sobre a presença desses metais nas amostras analisadas. Foi observado que a concentração de $\mathrm{Al}, \mathrm{Cr}$ e $\mathrm{Ni}$ nos pontos de coleta de açaí estavam superiores aos teores encontrados nas amostras de água coletadas pelo IEC e consequentemente maiores do que os limites máximos permitidos pela Resolução CONAMA № 357/2005.

\section{CONCLUSÃO}

A determinação dos constituintes inorgânicos $\mathrm{Al}$, $\mathrm{Ni}$ e $\mathrm{Cr}$ em amostras de açaí geram dados importantes com relação ao meio ambiente e a saúde humana. Devido as amostras analisadas terem sido coletadas no município de Barcarena e próximas ao Rio Murucuri, região essa com histórico de contaminação ambiental, as amostras de açaí obtidas nos 6 pontos ao longo do Rio e seus igarapés apresentaram concentrações próximas a dados obtidos na literatura. Segundo as informações coletadas, os teores de Al, Ni e Cr não possuem toxicidade elevada. De acordo com estudos do IEC e da Resolução CONAMA № $357 / 2005$, as amostras de açaí apresentaram concentração dos metais analisado superior ao estudo e ao CONAMA. Em vista dos resultados obtidos, infere-se que é de suma importância as análises de metais em espécies da região amazônica, principalmente em regiões com crescentes ações antropológicas.

\section{REFERÊNCIAS}

[1] Ali, A. K.; Alkhafajy, A. K. Assessment of heavy metal (Ni, Cr) contamination and spatial distribution in surface sediment and soil in the area of Lake Sawa. Inter Jour of Scien and Res, v. 5, n. 4, p.1089-1092, 2016.

[2] Anvisa - Agência Nacional de Vigilância Sanitária. Regulamento técnico sobre a ingestão diária recomendada (IDR) de proteínas, vitaminas e minerais. Resolução RDC $\mathrm{n}^{\circ} 269$, de 22 de setembro de 2005 . Disponível em: <http://portal.anvisa.gov.br/documents/33916/394219/RDC_269_2005.pdf/2e95553c-a482-45c3-bdd1-f96162d607b3>. Acesso em: 11 ago. 2019.

[3] Conama- Conselho Nacional de Meio Ambiente. Resolução n ${ }^{\circ} 357$, de 17 de março de 2005. Alterada pela Resolução 410/2009 e pela 430/2011. Diário Oficial da União - DOU, seção 1, n. 053, p. 58 - 63, 2005.

[4] Crisponi , Guido, et al. The meaning of aluminium exposure on human health and aluminium-related diseases. BioMol Concepts, v. 4, n. 1, p. 77-87, 2013.

[5] IEC - Instituto Evandro Chagas a . Avaliação dos impactos referente ao transbordo de efluentes de Lama Vermelha na Cidade de Barcarena, Estado do Pará. Relatório no 002/2018 Processo $\mathrm{n}^{\circ}$ 010/2018. Disponível em: <https://www.iec.gov.br/wp-content/uploads/2018/03/RELAT\%C3\%93RIO_T\%C3\%89CNICO_002-2018-compressed.pdf>. Acesso em: 24 jun. 2019.

[6] IEC - Instituto Evandro Chagas b. Avaliação Preliminar dos Impactos Ambientais Referente ao Transbordo e Lançamentos Irregulares de Efluentes de Lama Vermelha na Cidade de Barcarena, Estado do Pará. Relatório ${ }^{\circ} 003 / 2018$ $\begin{array}{lllll}\text { Processo } & \mathrm{n}^{\circ} & 010 / 2018 & \text { Disponível } & \mathrm{em}\end{array}$ content/uploads/2018/03/Relat\%C3\%93RIO_T\%C3\%89CNICO_SAMAM_003-2018.pdf>. Acesso em: 15 jun. 2019. 
[8] MPE-PA - Ministério Público do Estado do Pará; MPF - Ministério Público Federal. Inquérito civil público ${ }^{\circ}$ 1.23.000.000661/2015-70: Ação civil pública com pedido de liminar. 2015. Disponível em: http://www.mpf.mp.br/pa/salade-imprensa/documentos/2016/acp-agua-potavel-barcarena. Acesso em 20 jul. 2019.

[9] Neves, P. P. F. G. et al. Determinação de Metais em Espécies Florestais da Amazônia. Rev. Virt. Quím., v. 8, n. 5, p.1404 - 1420, 2016.

[10] Medeiros. A. C. et al. Quality index of the surface water of Amazonian rivers in industrial areas in Pará, Brazil. Marine Pollution Bulleti. v.123, p. 156-164, 2017

[11] Menezes, E. M. S. et al. Valor nutricional da polpa de açaí (Euterpe oleracea Mart) liofilizada. Acta Amaz., v. 38, n. 2, p. $311-316,2008$.

[12] Pereira, S. F. et al. Estudo químico ambiental do rio Murucupi - Barcarena, PA, Brasil, área impactada pela produção de alumínio. Rev. Ambiente e Água. v. 2, n. 3, p. 62-82, 2007.

[13] Ramos, M. G. M; Geraldo, L. P. Avaliação das espécies de plantas Avicennia Schaueriana, Laguncularia Racemosa e Rhizophora Mangle como bioindicadoras de poluição por metais pesados em ambientes de mangues. Eng. Sanit. e Amb., v. 12, n. 4, p. 440 - 445, 2007.

[14] Skalnaya, M. G.; Skalny, A. V. Essential trace elements in human health: a physician's. Tomsk: Publishing House of Tomsk State University, 2018.

Souza , A. K. R. et al. Poluição do ambiente por metais pesados e utilização de vegetais como bioindicadores. Acta Biomedica Brasiliensia, v. 3, n. 3, p. 95 - 106, 2018. 


\section{Capítulo 17}

Estudo da caracterização química de baterias de íonlítio obsoletas

\section{Keylla Castro Ferreira \\ Silvane Gonçalves e Gonçalves \\ Kleber Bittencourt Oliveira \\ Emanuel Negrão Macêdo \\ José Antônio da Silva Souza}

Resumo: 0 objetivo da pesquisa é caracterizar quimicamente as baterias de íon-lítio obsoletas. Para esse estudo selecionou-se 50 baterias de íons-lítio obsoletas. Essas baterias foram trituradas, classificadas em peneiras de $0,50 \mathrm{~mm}$, caracterizadas quimicamente por Espectrometria de Fluorescência de raios-X (FRX) e por Espectrometria de raios-X por Dispersão de Energia (EDS). Posteriormente amostra triturada foi submetida à lixiviação em água régia na concentração a $2 \mathrm{~N}$ durante 2 horas, com coletas de 30 em 30 minutos. Ao término da lixiviação as amostras foram filtradas, diluídas na proporção de 1:20 e foram encaminhadas para analise química de Espectrometria de Emissão Ótica por Plasma Acoplado Indutivamente (ICP-OES). Os resultados obtidos mostraram que as baterias de íon-lítio apresentam, com predominância, os metais de Cobalto, Manganês, Cobre e Níquel.

Palavras-chave: Baterias de íons-lítio; Lixiviação ácida; Metais; Caracterização química. 


\section{INTRODUÇÃO}

As baterias de Íons-Lítio revolucionaram as indústrias de dispositivos eletrônicos portáteis e provocaram profundas mudanças na comunicação global. Elas se tornaram a fonte de energia dominante em eletrônicos portáteis e sem fio, como: celulares, tablets, notebooks, câmeras digital e iPads (Santana, 2016).

Segundo Armand (2001) a crescente utilização das baterias de Íons-Lítio, no mercado, deve-se a sua alta densidade de energia quando comparada às demais baterias recarregáveis. As maiores vantagens e desvantagens das baterias de Íons-Lítio em relação às demais baterias estão resumidas na Tabela 1.

Tabela 1 - Vantagens e desvantagens das baterias de Íon-Lítio

\begin{tabular}{|l|l|}
\hline \multicolumn{2}{|c|}{ Vantagens } \\
\hline Célula selada; não requer manutenção & Custo inicial moderado \\
\hline Longo ciclo de vida & Degradação a temperaturas altas \\
\hline Temperatura de operação amena & Necessidade de um circuito de proteção \\
\hline Grande estabilidade em armazenamento & Perda de capacidade ou fuga térmica \\
\hline Baixa taxa de auto descarga & Descarrega quando quebrada \\
\hline Rápida capacidade de carga & $\begin{array}{l}\text { Quando construídas em design cilíndrico oferecem } \\
\text { menos densidade de energia que baterias de NiCd e } \\
\text { NiMH }\end{array}$ \\
\hline Alta taxa e potência de descarga & \\
\hline Alta eficiência coulumbiana e energética & \\
\hline Alta energia específica e densidade de energia & \\
\hline Não possui efeito memória & \\
\hline
\end{tabular}

No Brasil, a regulamentação específica para tratamento de resíduos de pilhas e baterias é definida pela Lei 12.305/2010, que institui a Política Nacional de Resíduos Sólidos (PNRS), dispondo sobre seus princípios, objetivos e instrumentos, e sobre as diretrizes relativas à gestão integrada e ao gerenciamento de resíduos sólidos, incluídos os perigosos, às responsabilidades dos geradores e do poder público e aos instrumentos econômicos aplicáveis.

Com o crescimento significativo da utilização das baterias de íons-lítio aumenta-se também o a quantidade de baterias descartadas inadequadamente. Deste modo torna-se imprescindível um estudo da caracterização química, dessas baterias, para posteriormente se traçar uma rota de recuperação dos metais presente nelas, visando à minimização dos impactos ambientais gerados pelos descartes incorretos das mesmas.

\section{MATERIAS E MÉTODOS}

Para o desenvolvimento do estudo de caracterização química das baterias de íons-lítio utilizou-se o esquema da Figura 1 abaixo:

Figura1 - Fluxograma do processo de caracterização química das baterias de íons-lítio.

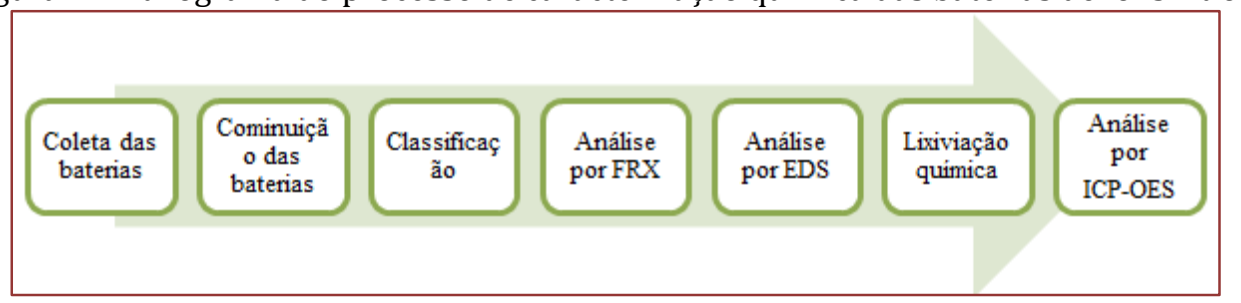

Inicialmente foram coletadas 50 baterias de Íons-Lítio de celular obsoletas, em um posto de coleta seletiva localizado em um dos supermercados da região metropolitana de Belém, Estado do Pará. Após a coleta as baterias de íons-lítio foram trituradas em um Triturador Forrageiro TRF600 Trapp e posteriormente submetido a uma etapa de separação granulométrica, utilizando peneiras de abertura entre $4,76 \mathrm{~mm}$ a $0,50 \mathrm{~mm}$, para se obter amostra com granulometria inferior a $1 \mathrm{~mm}$ para a análise de Espectrometria de 
Fluorescência de raios-X (FRX) e análise de Espectrometria de raios-X por Dispersão de Energia (EDS) (Figura 2).

Figura 2 - (a) Baterias coletadas, (b) Baterias trituradas, (c) Baterias com granulometria menor que 0,5
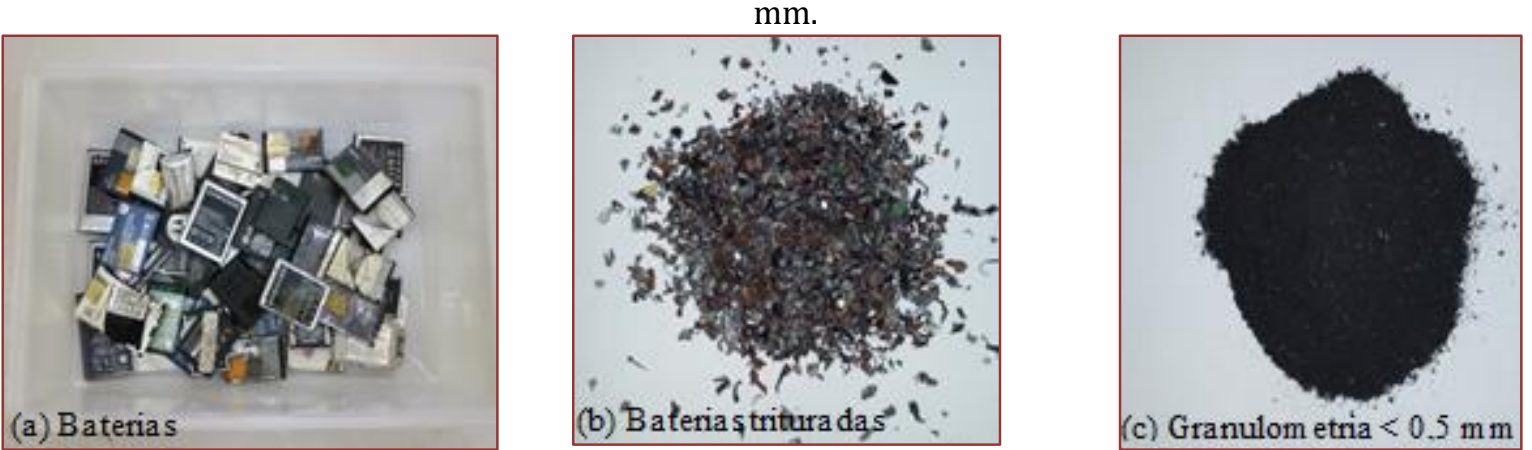

Na análise de FRX, utilizou-se um espectrômetro WDS sequencial, modelo Axios Minerals da marca PANalytical, com tubo de raios-X cerâmico, anodo de ródio(Rh) e máximo nível de potência 2,4 KW. A amostra foi analisada por preparação de pastilha prensada: amostra + aglomerante (cera de parafina), sob substrato de ácido bórico $\left(\mathrm{H}_{2} \mathrm{BO}_{2}\right)$. A mistura foi prensada com uma carga de 25 toneladas com diâmetro da pastilha de $33 \mathrm{~mm}$ e espessura de $3 \mathrm{~mm}$. As aquisições e tratamento de dados foram realizados através do software SuperQ Manager da PANalytical. A FRX da amostra foi realizada no Laboratório de Caracterização Mineral Raios-X no Instituto de Geociências da UFPA.

A análise por espectrometria de raios-X por dispersão de energia foi realizado no equipamento MEV Zeiss modelo LEO-1430, com EDS Sirius-SD acoplado. As condições de operação para as análises de EDS (energy dispersive spectroscopy) foram: corrente do feixe de elétrons $=90 \mu \mathrm{A}$, voltagem de aceleração constante $=$ $20 \mathrm{kV}$, distância de trabalho $=15 \mathrm{~mm}$, tempo de contagem para análise dos elementos $=30 \mathrm{~s}$. A análise de EDS da amostra foi realizada no Laboratório de Microanálises do Instituto de Geociências da UFPA.

Na análise por EDS, utilizou-se o equipamento MEV Zeiss modelo LEO-1430, com EDS Sirius-SD acoplado. As condições de operação para as análises de EDS (energy dispersive spectroscopy) foram: corrente do feixe de elétrons $=90 \mu \mathrm{A}$, voltagem de aceleração constante $=20 \mathrm{kV}$, distância de trabalho $=15 \mathrm{~mm}$, tempo de contagem para análise dos elementos = $30 \mathrm{~s}$. As análises foram realizadas no Laboratório de Microanálises do Instituto de Geociências da UFPA.

No processo de lixiviação química foi utilizado água régia a $2 \mathrm{~N}$ na proporção de 1:3 de soluções de ácidos nítrico a $2 \mathrm{~N}$ e clorídrico a $2 \mathrm{~N}$, para uma relação de sólido/líquido $1 \mathrm{~g}$ para $20 \mathrm{ml}$. A lixiviação química foi realizada a uma temperatura de ${ }^{8}{ }^{\circ} \mathrm{C}$ no tempo de $2 \mathrm{~h}$ de digestão (Petter et al., 2012). Durante a lixiviação foram retiradas alíquotas de $30 \mathrm{ml}$ de 30 em 30 minutos, com o intuito de se identificar os metais presentes nas baterias de Íons-Lítio. Ao término da lixiviação alíquotas e o sistema foram filtrados e as soluções concentradas de metais foram encaminhadas para análise química de Espectrometria de Emissão Ótica por Plasma Acoplado Indutivamente (ICP-OES) do tipo Vista MPX da marca Varian. A análise por ICPOES foram feitas no Laboratório de Toxicologia, Setor de Espectrometria II - Seção Meio Ambiente do Instituto Evandro Chagas.

\section{RESULTADOS E DISCUSSÃO}

\subsection{COMPOSIÇÃO QUÍMICA DAS BATERIAS DE ÍONS-LÍTIO}

A Tabela 2 apresenta os resultados da análise de FRX realizada na amostra passante da peneira de abertura 0,50 mm. Os resultados mostraram que a composição das baterias de Íons-Lítio mostrou-se bem variada com predominância do Co (75,83\%) seguida de Mn $(11,19 \%)$, Cu $(5,59 \%)$ e do Ni $(3,10 \%)$, que comprova a existência dos metais de interesse para o processo de recuperação. Observou-se ainda que os resultados da FRX foram compatíveis com os resultados da EDS, uma vez que, foram analisadas as mesmas amostras, afim de ratificar os metais encontrados na análise de FRX. 
Tabela 2 - Composição química das baterias de Íons-Lítio

\begin{tabular}{|c|c|}
\hline \multicolumn{1}{|c|}{ Componetes } & $\% \mathrm{~m} / \mathrm{m}$ \\
\hline $\mathrm{Al}$ & 0,77 \\
\hline $\mathrm{Ba}$ & 0,48 \\
\hline $\mathrm{Ca}$ & 0,17 \\
\hline $\mathrm{Co}$ & 75,83 \\
\hline $\mathrm{Cu}$ & 5,59 \\
\hline $\mathrm{Fe}$ & 0,79 \\
\hline $\mathrm{Mn}$ & 11,19 \\
\hline $\mathrm{Nb}$ & 0,06 \\
\hline $\mathrm{Ni}$ & 3,10 \\
\hline $\mathrm{P}$ & 1,61 \\
\hline $\mathrm{Pb}$ & 0,07 \\
\hline $\mathrm{Si}$ & 0,32 \\
\hline $\mathrm{Sn}$ & 0,21 \\
\hline
\end{tabular}

Figura 3 - Gráfico por EDS da composição química das baterias de íons-lítio.

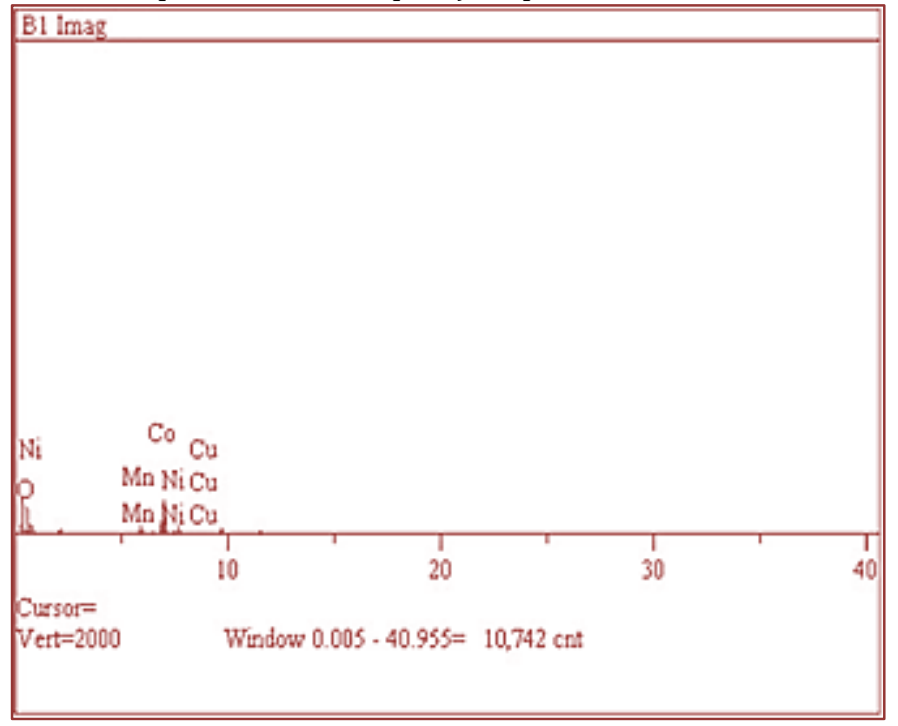

Na análise de ICP-OES do processo de lixiviação observou-se que o principal elemento em concentração é o cobalto, seguido do alumínio, cobre e ferro. No entanto, a presença do alumínio é devido às carcaças que envolvem as baterias serem de ligas de alumínio e a presença de ferro é devido às mesmas, estarem oxidadas (Tabela 3). Observou-se ainda que a extração foi melhor para os metais de Co, Mn, Cu e Fe como mostra Tabela 3 uma possível justificativa para essa extração está na concentração da solução e no tipo de reagente que foi utilizado no processo de lixiviação ácida neste trabalho (Calgaro et al., 2012 e Moraes, 2011).

Tabela 3 - Caracterização da solução de metais obtida na lixiviação química após 90 minutos de extração

\begin{tabular}{|c|c|c|c|} 
Componentes & $\begin{array}{c}\text { Concentração } \\
(\mathrm{ppm})\end{array}$ & Elemento & $\begin{array}{c}\text { Concentração } \\
\text { (ppm) }\end{array}$ \\
\hline $\mathrm{Al}$ & 62,99 & $\mathrm{Fe}$ & 207,60 \\
\hline $\mathrm{Ba}$ & 278,78 & $\mathrm{~K}$ & 34,37 \\
\hline $\mathrm{Ca}$ & 788,58 & $\mathrm{Mg}$ & 855,02 \\
\hline $\mathrm{Cd}$ & 253,55 & $\mathrm{Mn}$ & 2895,08 \\
\hline $\mathrm{Co}$ & 4607,19 & $\mathrm{Ni}$ & 2070,60 \\
\hline $\mathrm{Cr}$ & 6,58321 & $\mathrm{~Pb}$ & $<\mathrm{LD}$ \\
\hline $\mathrm{Cu}$ & 2791,80 & $\mathrm{Zn}$ & $<\mathrm{LD}$ \\
\hline
\end{tabular}




\section{CONCLUSÕES}

A partir dos estudos realizado neste trabalho, os resultados das análises de caracterização química FRX, EDS, realizado nas baterias trituradas, e ICP-OES, realizado na solução de metais obtidas a partir da lixiviação, mostraram que as baterias de Íons-Lítio apresentam uma variedades de metais, apresentando uma quantidade relativa dos metais de $\mathrm{Co}, \mathrm{Mn}, \mathrm{Cu}$ e $\mathrm{Ni}$, tornando esse tipo de resíduo, como fonte de matéria-prima para processos de recuperação desses metais.

Nas análises de lixiviação foi possível extrair em solução os metais de $\mathrm{Co}, \mathrm{Mn}, \mathrm{Cu}$ e $\mathrm{Ni}$ em grandes quantidade de concentração, respectivamente, além de outros metais como $\mathrm{Al}, \mathrm{Ba}, \mathrm{Ca}, \mathrm{Cd}, \mathrm{Cr}, \mathrm{Fe}, \mathrm{K}, \mathrm{Mg}$ em menor quantidades de concentração, utilizando água régia a $2 \mathrm{~N}$ nas condições de tempo e temperatura estudada.

Esse trabalho demonstrou que a caracterização química de baterias de Íons-Lítios obsoletas é de suma importância para a recuperação maximizada de metais de alto valor, como Co e $\mathrm{Cu}$, e uma opção para o descarte, de forma segura, desse tipo de material.

\section{REFERÊNCIAS}

[1] Armand, M., Tarascon, J. Issues and challenges facing rechargeable lithium batteries. Insight Review Articles, v. 414, n. November, p. 359-367, 2001.

[2] Calgaro, C. O.; Albiero, J. K.; Meieli, L.; Rosa, M. B.; Bertuol,D. Recuperação de Cobalto de Baterias Íon-Lítio através de Lixiviação Ácida e Eletro-Obtenção. Revista Eletrônica em Gestão, Educação e Tecnologia Ambiental, v. 5, № 5 , p. 867-874, 2012.

[3] Moraes, V. T. Recuperação de Metais a partir do Processamento Mecânico e Hidrometalurgico de Placas de Circuito Impressos de Celulares Obsoletos. São Paulo. 2011. Tese de Doutorado - Escola Politécnica da Universidade de São Paulo. Departamento de Engenharia Metalúrgica e de Materiais, 2011.

[4] Petter, P. M. H., Bernardes, A. M., Veit, H. M., Brito, D. O. Estudos de Lixiviantes Alternativos para Extração de Placa de Circuito Impresso. VIII Simpósio Internacional de Qualidade Ambiental, Centro de Eventos da PURCS, Porto Alegre - RS, 2012.

[5] Santana, I. L. Reciclagem de eletrodo positivo de baterias de íon-Li exauridas utilizando ácido cítrico como lixiviador e precursor na formação de eletroquímica de $\mathrm{Co}(\mathrm{OH})_{2} / \mathrm{Co}_{3} \mathrm{O}_{4} / \mathrm{LiCoO}_{2}$ e química de $\mathrm{Co}_{3} \mathrm{O}_{4} / \mathrm{LiCoO}_{2}$ e $\mathrm{LiCoO}_{2}$. Vitória, 2016. Dissertação de mestrado-Programa de Pós-Graduação em Química-Universidade Federal do Espirito Santo, 2016. 


\section{Capítulo 18}

Produção de sabão ecológico a partir do óleo vegetal extraído da semente de Cupuaçu

\section{Samara de Paula Pinheiro Menezes Marques}

\section{Mário Lucivaldo Barreto de Jesus}

\section{Rafaela Oliveira Pinheiro}

Resumo: 0 aproveitamento de gorduras e óleos regionais extraídos de frutas, por exemplo, tem sido bastante alvo de pesquisas. A região Amazônica, rica em frutas exóticas, fornece óleos e gorduras de qualidade que são empregadas na produção de shampoos, hidratantes, sabonetes, etc. Empresas famosas fazem sucesso cada vez mais e têm público garantido para tais produtos. 0 cupuaçu (Theobroma Grandiflorum) apresenta característica marcante de hidratação daí ter sido escolhido no desenvolvimento desta pesquisa. 0 objetivo do trabalho foi extrair por prensa, o óleo das sementes de cupuaçu adquiridas no mercado do Ver-0 -Peso e posteriormente elaborar um sabão com o mesmo. 0 método escolhido foi por prensa hidráulica devido não necessitar de uso de reagentes para a sua extração. Foram realizadas análises físicoquímicas (acidez em ácido oléico e índice de saponificação) do óleo extraído. Os resultados foram satisfatórios e de acordo com legislação e bibliografia consultada. 


\section{INTRODUÇÃO}

As sementes oleaginosas, muito comum em nossa região, como as sementes de andiroba, murumuru, pracaxi, cupuaçu, ucuuba e muitas outras produzem óleos vegetais de excelente qualidade, que podem ser usados na produção de sabão e sabonetes, creme hidratantes etc.

O sistema de obtenção deste tipo de óleos é simples; um dos mais usados é o de prensa hidráulica. Colocase a semente para secar, ou seja, retirar toda a umidade existente nesta semente; quando necessário, tritura-se estas semente e em seguida leva-se a prensa, onde sob alta pressão obtém o óleo desejado. Podemos classificar como nobre os produtos obtidos deste tipo de óleo, gorduras ou manteigas vegetais. São produtos ricos em ácidos graxos, beta carotenos e outros tipos de vitaminas, que podem ser usado na pele e cabelos.

De acordo com Allinger (1976) os óleos e gorduras são compostos por ácidos graxos, os quais quando corretamente misturados, em proporções corretas, com bases fortes como o hidróxido de sódio produzem os sabões. Esta reação química é denominada saponificação.

Para Mercadante (2009) a produção de sabões que não ofereçam riscos à saúde humana alguns critérios devem ser atendidos, um deles é o índice de saponificação. De acordo com Normas (2008) o índice de saponificação é a quantidade de álcali necessário para saponificar uma quantidade definida de amostra. Dessa forma esta pesquisa tem por objetivo produzir sabões ecológicos a partir de óleo extraído de fruta e previamente analisar a qualidade físico-química do óleo através das análises de índice de saponificação e de acidez em ácido oléico.

\subsection{SEMENTE DE CUPUAÇU (THEOBROMA GRANDIFLORUM)}

O óleo extraído das sementes do cupuaçu oferece propriedades fantásticas para a indústria cosmética. A manteiga de cupuaçu é um triglicerídio que apresenta uma composição equilibrada de ácidos graxos saturados e insaturados, o que confere ao produto um baixo ponto de fusão (aproximadamente $30^{\circ} \mathrm{C}$ ) e aspecto de um sólido macio que se funde rapidamente ao entrar em contato com a pele.

A manteiga de cupuaçu possui alto poder de absorção de água, aproximadamente $240 \%$ superior a da Lanolina, atuando como um substituto vegetal da mesma. Ela contém fitoesteróis (especialmente betasitosterol) que atuam a nível celular regulando o equilíbrio hídrico e a atividade dos lipídeos da camada superficial da pele.

0 alto poder de absorção da água da Manteiga de Cupuaçu pode ser atribuído às pontes de hidrogênio formadas entre as moléculas de água e os fitoesteróis.

O cupuaçu tem uma tremenda capacidade de absorção de água e oferece benefícios comprovados hidratação da pele que ajudam a restaurar a umidade natural e a elasticidade, altamente adequado para a produção de cosméticos.

De acordo com Azevedo; Kopcak; Mohamed (2003) apud Teixeira (2014) as sementes têm um teor de gordura elevado (62\%), com características que se assemelham ao da manteiga de cacau e com potenciais aplicações nas indústrias de cosméticos, produtos farmacêuticos e alimentares.

De acordo com Crodamazon (2016) a manteiga da semente de cupuaçu tem uma alta capacidade de absorção da água, aproximadamente 240 \% superior a da lanolina. Além disso, apresenta certo grau de absorvância de UV, UVB e UVC. A manteiga de cupuaçu contém fitoesteróis que atuam em nível celular, regulando o equilíbrio hídrico e a atividade dos lipídeos da camada superficial da pele.

\section{2 - MATERIAL E MÉTODOS}

\subsection{ANÁLISES FÍSICO-QUÍMICAS DA GORDURA DE CUPUAÇU}

\section{Metodologia de Extração}

A extração por prensa foi realizada com prensa hidráulica conforme a Figura 30 t e curso hidráulico de $150 \mathrm{~mm}$. 
Figura 1 - Extração por prensa.

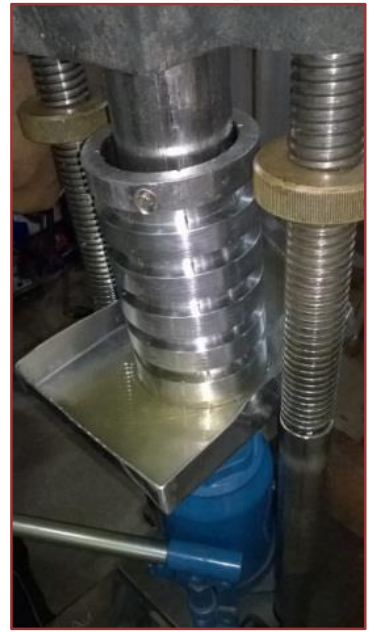

\section{Acidez Em Ácido Oléico}

A acidez em ácido oléico foi determinada através da dissolução de amostras de 2 g de gordura de cupuaçu em $25 \mathrm{~cm}^{3}$ de solução Éter-Álcool 2:1, utilizando 2 gotas de solução Etanólica de Fenolftaleína a 1 \% como indicador. Em seguida, titulou-se com solução aquosa de Hidróxido de Sódio 0,1 N, até coloração rósea persistente por $15 \mathrm{seg}$, (NORMAS, 2008). Este parâmetro foi determinado pela Equação 1.

\section{$\%$ Acidez em ácido oléico $=\frac{V \times N \times F c \times 28,2}{M}$}

Onde:

V = volume de solução de hidróxido de sódio 0,1 N gasto na titulação;

$\mathrm{N}=$ normalidade da solução de hidróxido de sódio

Fc= Fator de correção da solução de hidróxido de sódio

$\mathrm{M}=$ massa da amostra em gramas;

28,2 = deciequivalente-grama do ácido oléico.

Índice de Saponificação

Foram pesados $4 \mathrm{~g}$ de amostra e transferidos para balão de fundo chato de $250 \mathrm{~cm}^{3}$. Em seguida foi adicionado $50 \mathrm{~cm}^{3}$ de solução alcoólica de hidróxido de potássio $4 \%$ ao balão de fundo chato e o mesmo foi colocado em sistema de refluxo por $1 \mathrm{~h}$ e $30 \mathrm{~min}$, até completa saponificação. Foi preparado um branco paralelamente à analise. Ao término do processo e resfriamento do balão foi adicionado $1 \mathrm{~cm}^{3} \mathrm{do}$ indicador Fenolftaleína 1\% e a solução foi titulada com solução de Ácido Clorídrico 0,5 M. 0 término da titulação foi observado com o desaparecimento da coloração rósea. 0 cálculo do índice de saponificação foi feito a partir da Equação 2 (NORMAS, 2005).

$$
\text { Índice de saponificação }=\frac{28,06 \times F c \times(B-A)}{P}
$$

Onde:

$\mathrm{A}=$ volume gasto na titulação da amostra $\mathrm{em}^{\mathrm{cm}}{ }^{3}$

$\mathrm{B}=$ volume gasto na titulação do branco em $\mathrm{cm}^{3}$ 
Fc = Fator da solução de ácido clorídrico 0,5 M

$\mathrm{P}=$ massa da amostra em $\mathrm{g}$.

\subsection{PRODUÇÃO DE SABÃO EM BARRA ECOLÓGICO}

O sabão em barra ecológico foi elaborado com os componentes químicos na Tabela 1.

Em um recipiente plástico foi inserido $125 \mathrm{~L}$ de água quente a $60 \circ \mathrm{C}$ e em seguida foi adicionado o hidróxido de sódio. A mistura foi deixada em repouso por 40 minutos.

Em outro recipiente plástico foi inserido o óleo de cupuaçu e o álcool. A mistura foi deixada em repouso por 40 minutos.

Após esse período, a mistura que contém o óleo e o álcool foi adicionada lentamente ao recipiente que contém o hidróxido de sódio.

A mistura foi homogeneizada com bastão de madeira por 60 minutos até atingir coloração marrom. 0 acondicionamento foi feito em formas de silicone.

Tabela 1 - Componentes químicos utilizados durante o trabalho

\begin{tabular}{|c|c|}
\hline Produto Químico & Quantidade por ensaio \\
\hline Óleo de cupuaçu & $250 \mathrm{~mL}$ \\
\hline Hidróxido de sódio & $41,66 \mathrm{~g}$ \\
\hline Álcool etílico $98,2^{\circ}$ & $208,33 \mathrm{~mL}$ \\
\hline Água destilada & $125 \mathrm{~mL}$ \\
\hline
\end{tabular}

\section{3 - RESULTADOS}

\subsection{ACIDEZ EM ÁCIDO OLÉICO}

Os resultados variaram de 1,70 \% a 1,78 \%,com média igual a 1,73\% e desvio padrão de 0,03.

A amostra se apresentou em conformidade com ANVISA (2000), a qual estabelece o valor máximo de 5\% para este parâmetro. Resultados dentro do estabelecido indicam que as amostras se encontram em bom estado de conservação podendo ser aplicadas nas indústrias cosmética e alimentícia por exemplo.

\section{2. ÍNDICE DE SAPONIFICAÇÃO}

Os resultados de saponificação obtidos experimentalmente para a amostra, variaram de 187,72 mg KOH/g a 188,39 mg KOH/g, com média igual a 188,17 mg KOH/g e desvio padrão igual a 0,30.

De acordo com Emfal (2015) os valores tomados como referência para o índice de saponificação variam entre 170,00 a 200,00 mg KOH/g.

De acordo com Mapa (2012) para azeite de oliva virgem o valor padrão recomendado é de 184 a 196 mg $\mathrm{KOH} / \mathrm{g}$ para índice de saponificação.

Os resultados indicam que as amostras encontram-se em bom estado de conservação, podendo serem aplicadas na indústria cosmética.

\subsection{SABÃO PRODUZIDO}

O sabão foi produzido em uma forma arredondada como pode ser visualizado na Figura 2. 


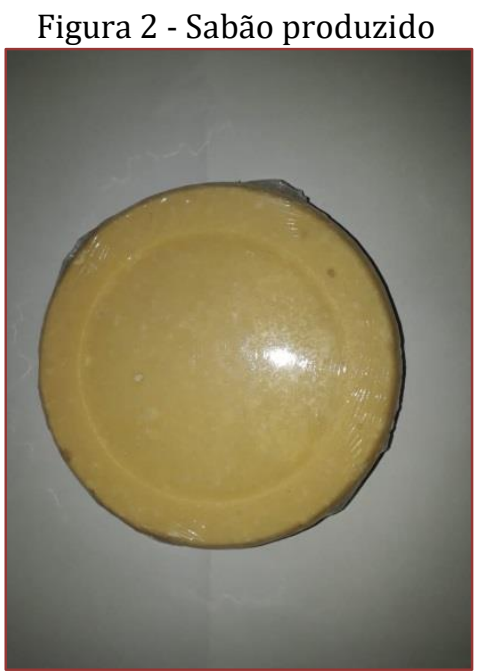

\section{CONCLUSÕES}

A partir dos resultados obtidos podemos concluir que o objetivo da pesquisa foi alcançado, haja vista que o sabão foi elaborado com sucesso e o óleo extraído apresentou características físico-químicas de acidez em ácido oleico e índice de saponificação de acordo com a legislação vigente.

\section{REFERÊNCIAS}

[1] Allinger, Norman. Química Orgânica. 2. ed. Rio de janeiro: [s.n.], 1976.

[2] Anvisa- Agencia Nacional de Vigilancia Sanitária. Resolução da diretoria colegiada RDC no 270 , de 22 de setembro de 2000- Regulamento técnico para Óleos vegetais, gorduras vegetais e creme vegetal.

[3] Crodamazon: Gordura de cupuaçu. Disponível em: <

https://www.google.com.br/search?q=crodamazom\&ie=utf-8\&oe=utf-8\&client=firefoxb\&gfe_rd=cr\&ei=WsrFV_jLDsSU8QfliKLQCA\&gws_rd=cr\#>.

[4] Emfal- Especialidades Químicas. Ficha de Informação Técnica: Manteiga de Cupuaçu. Registro $078,2015$.

[5] Luz, Luiz Augusto Rodrigues Da. Testes Físico-químicos em Derivados de Petróleo. [S.l: s.n.], 2007. 196 p.

[6] Mapa - Ministério da Agricultura, Pecuária e Abastecimento. Instrução Normativa no 1, de 30 de janeiro de 2012- Regulamento para Azeite de oliva.

[7] Mercadante, Ricardo et.al. Massa base para sabonetes. In_Fabricando sabonetes sólidos. Projeto Gerart VII, [s.n], 2009. Disponível em: Acesso em: 06 abr. 2015

[8] Normas Analíticas do Instituto Adolfo Lutz. Métodos químicos e físicos para análise de alimentos. 4. ed., v. 1. São Paulo: Instituto Adolfo Lutz, 2008.

[9] Teixeira, Gerson Lopes. Estudo da estabilidade e comportamento reológico de emulsões de gordura de cupuaçu (theobroma grandiflorum) com diferentes tensoativos. 91f., 2014. Dissertação (Mestrado em Engenharia de alimentos)Programa de Pós-graduação em Engenharia de alimentos, Universidade Federal Do Paraná, Curitiba. 


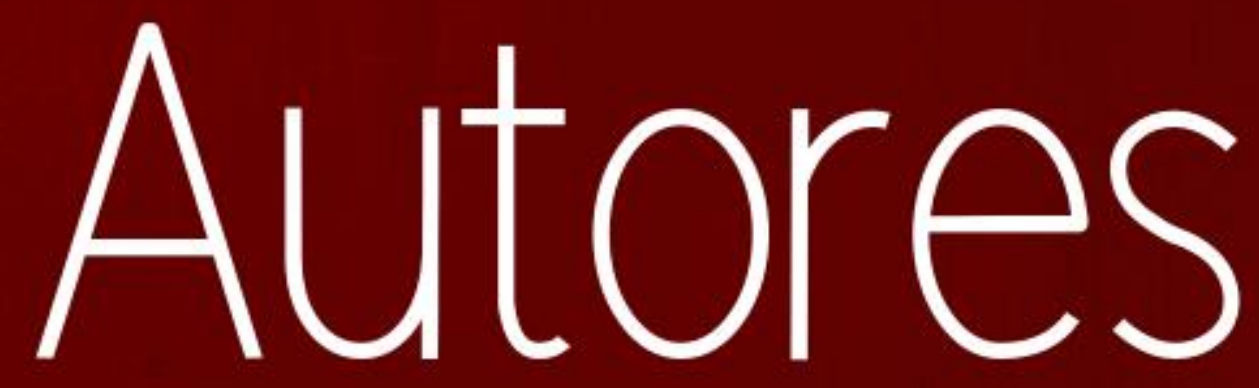




\section{ALEXANDRO CEZAR FLORENTINO}

Doutor em Ciências Biológicas (Biologia de Água Doce e Pesca Interior) pelo Instituto Nacional de Pesquisas da Amazônia (INPA). Foi bolsista de Desenvolvimento Cientifico Tecnológico Regional C (DCR - CNPq e FAPEAP) junto ao setor de Aquicultura e Pesca da EMBRAPA AMAPÁ (2013-2014). Atualmente é professor Adjunto na Universidade Federal do Amapá (UNIFAP). Trabalha principalmente com ecologia de peixes e recursos pesqueiros. Participa como orientador nos Cursos de Pós - Graduação em Ciências Ambientais - PPGCA (Mestrado) e Biodiversidade Tropical - PPGBio (Mestrado/Doutorado).

\section{ALEXSANDRO SOZAR MARINS}

Possui graduação em Química Industrial pela Universidade Federal do Pará (2008), graduação em licenciatura em Química pelo Instituto Federal do Pará (2009), mestrado em Química pela Universidade Federal do Pará (2009) e doutorado em Química (área: Química Analítica) pela Universidade Federal do Pará (2019). Tem experiência na área de Química Analítica, com ênfase em técnicas espectroanalíticas e ensino de Química.

\section{ALLYSON ALLENNON PINHEIRO DO ROSÁRIO}

Graduado em Farmácia pela Faculdade de Farmácia da Universidade Federal do Pará, tendo experiencia em análises químicas de produtos alimentícios. Integrante do laboratório de Física Aplicada à Farmácia (LAFFA) da UFPA.

\section{AMARILIS SEVERINO E SOUZA}

Mestre em Engenharia Química pela Universidade Federal de São Carlos (UFSCar). Graduação em Engenharia Química (2017) pela Universidade Federal do Triângulo Mineiro (UFTM). Atua na área de sistemas particulados, com ênfase na simulação de escoamentos multifásicos por fluidodinâmica computacional (CFD). É integrante do Laboratório de Simulação em Escoamentos Multifásicos (LabSEM) e do Centro de Secagem de Pastas e Sementes (CS) do DEQ-UFSCar.

\section{ANDERSON MATHIAS PEREIRA}

Possui Graduação em Engenharia de Alimentos pela Universidade Federal do Pará, Especialização em Produção de Biodiesel pela Universidade Federal Rural da Amazônia, Mestrado em Engenharia Química pela Universidade Federal do Pará e Doutorado em Engenharia de Recursos Naturais pela Universidade Federal do Pará. Atualmente é professor da Universidade Federal do Amazonas atuando no Curso de Engenharia de Alimentos. Tem experiência na área de Engenharia de Alimentos e Engenharia Química, com ênfase em Processos Orgânicos, atuando principalmente nos seguintes temas: Tecnologia de óleos e gorduras, biocombustíveis (craqueamento, biodiesel e etanol) e extração supercrítica.

\section{ANDRÉ LUIS CALADO ARAÚJO}

Possui graduação em Engenharia Civil pela Universidade Federal do Pará (1990), mestrado em Mestrado em Engenharia Sanitária pela Universidade Federal de Campina Grande (1993) e doutorado em Engenharia Civil - University of Leeds (1999). Professor do Instituto Federal de Educação, Ciência e Tecnológia do Rio Grande do Norte. Tem experiência na área de Engenharia Sanitária, com ênfase em Tratamento de Águas Residuárias, atuando principalmente nos seguintes temas: tratamento de esgotos, monitoramento ambiental, qualidade ambiental e gestão ambiental. 


\section{ANDRÉ LUÍS LOPES MORIYAMA}

Possui graduação em Engenharia Química pela Universidade Federal do Rio Grande do Norte (2009), mestrado em Engenharia Química pela Universidade Federal do Rio Grande do Norte (2011), doutorado em Engenharia Química pela Universidade Federal do Rio Grande do Norte (2014), e doutorado em Química pela Université de Toulon (2014). Atualmente é professor adjunto do Departamento de Engenharia Química da Universidade Federal do Rio Grande do Norte. Tem experiência na área de Engenharia Química, Engenharia de Petróleo e Ciências de Materiais. Atualmente, desenvolve atividades focadas em tecnologias ambientais e termodinâmica, envolvendo principalmente a síntese de nanomateriais à base de óxidos mistos para aplicação em diferentes processos químicos e na detecção de gases poluentes.

\section{ANDRÉ LUÍS SANTOS DE PINHO}

Possui graduação em GRADUACAO EM ESTATISTICA pela Escola Nacional de Ciências Estatísticas (1992), mestrado em Estatística pela Universidade Estadual de Campinas (1995), mestrado em Engenharia Industrial - University of Wisconsin - Madison (2002) e doutorado em Engenharia Industrial - University of Wisconsin - Madison (2003). Atualmente é professor associado da Universidade Federal do Rio Grande do Norte. Tem experiência na área de Probabilidade e Estatística, com ênfase em Planejamento de Experimentos, atuando principalmente nos seguintes temas: planejamento de experimentos, unreplicated two-level factorial designs, split-plot, design e séries temporais e controle estatístico de processos.

\section{ANTONIO DOS SANTOS SILVA}

Físico (licenciatura e bacharelado); Químico (licenciatura e industrial); Estatístico (bacharelado); Mestre (em Física e em Química); Doutorando (Química Analítica). Especialista em Metodologia do Ensino de Biologia e Química; Educação a Distância: Gestão e Tutoria e em Ludopedagogia. Professor Adjunto da Faculdade de Farmácia da Universidade Federal do Pará. Tem experiência em análises químicas de produtos alimentícios (polpas de frutas, licores, mel, etc.). Professor responsável pelo Laboratório de Física Aplicada à Farmácia (LAFFA) da UFPA.

\section{BEATRIZ CRISTINA SILVÉRIO}

Atua como docente DE da classe Adjunto na Universidade Federal do Triângulo Mineiro - UFTM. Atualmente é docente do Departamento de Engenharia de Alimentos da UFTM. Possui graduação (2008), mestrado (2010) e doutorado (2012) em Engenharia Química pela Universidade Federal de Uberlândia. Atuou como professora DE da Universidade Federal de Goiás no Instituto de Química nos anos de novembro de 2012 à março de 2015. Tem experiência na área de Processos de Separação na Engenharia Química, atuando nos seguintes temas: secadores rotativo e rotoaerado, secagem de frutas e de fertilizantes, transferência de massa e fluidodinamica computacional, reaproveitamento de resíduos industriais, processos de separação em hidrociclones.

\section{BIANCA GUIMARÃES}

Doutoranda e Mestra em Engenharia e Ciência dos Alimentos pela Universidade Estadual Paulista (Unesp)-São José do Rio Preto-SP e graduada em Engenharia Química pela Universidade Federal do Triângulo Mineiro (UFTM) - Uberaba, MG. Foi bolsista de Iniciação Científica pela Fapemig (Fundação de Amparo à pesquisa de Minas Gerais) duas vezes. O seu Trabalho de Conclusão de Curso teve ênfase no aproveitamento sustentável de Biomassa (amendoim). Na dissertação estudou a produção de malte de trigo utilizando o ultrassom de alta potência durante a etapa da hidratação. Atualmente, vem atuando em áreas que envolvem reologia e ultrassom de alta potência e ministra a disciplina Química de Alimentos para o $4^{\circ}$ período de Engenharia de Alimentos da Unesp- São José do Rio Preto. 


\section{BRUNO CASTRO BARBALHO}

Professor de Físico-Química do Instituto Federal de Educação, Ciência e Tecnologia do Rio Grande do Norte campus São Paulo do Potengi-RN. Possui mestrado em Engenharia Química pela Universidade Federal do Rio Grande do Norte (2012), graduação em Licenciatura em Química pela Universidade Federal do Rio Grande do Norte (2011), graduação em Tecnologia em Gestão Ambiental pelo Instituto Federal de Educação, Ciência e Tecnologia do Rio Grande do Norte (2008) e graduação em Bacharelado em Química pela Universidade Federal do Rio Grande do Norte (2008). Tem experiência na área de Química, com ênfase em Físico-Química, atuando principalmente nos seguintes temas: impactos ambientais, condutividade, espectroscopia de impedância, dióxido de titânio, Microflotação e tratamento de água e efluentes.

\section{BRUNO HENRIQUE ALVES MENDES}

Possui Curso Técnico em Mineração (IFPA - Campus Belém), curso Técnico em Segurança do Trabalho (IFPA - Campus Belém), Graduação em Engenharia Química com previsão de formação para 2017, onde atua na área de materiais. Ministrou curso de AutoCAD com ênfase em desenho técnico em projeto de extensão ministrado no Instituto Federal do Pará.

\section{CHARLES ALBERTO BRITO NEGRÃO}

Graduado em Engenharia Química em 2014 pela Universidade Federal do Pará, mestre em FísicoQuímica em 2017 pela Universidade Federal do Pará. Atualmente doutorando do programa de pósgraduação em química da UFPA, na área de química analítica. Possui experiência nas áreas de catálise, adsorção, análise térmica, química quântica relativística, análises de alimentos e fitoquímica.

\section{CHARLES MILLER DE SOUZA BORGES}

Possui curso técnico de nível médio em química e graduação em licenciatura química, ambos cursados no Instituto federal do para, e cursando mestrado em química, subárea analítica na universidade federal do para.

\section{CIBELE CINTIA LOPES PIRES}

Graduanda em licenciatura plena em ciências naturais com habilitação em Química pela Universidade do Estado do Pará.

\section{DAYANA ROSY SOUZA DOS SANTOS}

Engenheira Sanitarista e Ambiental UFPA (2011), graduada em Ciência e Tecnologia com enfâse em Tecnologia Mineral pela Universidade Federal do Pará (2018). Atualmente é graduanda em Engenharia Biomédica (UFPA) e Técnico em Mineração (IFPA). 


\section{DEIBSON SILVA DA COSTA}

Possui graduação em Engenharia Mecânica pela Universidade Federal do Pará (2009). Mestrado em Engenharia Mecânica pela Universidade Federal do Pará (2012), na área de Concentração de Materiais e Processos de Fabricação sub-área de Materiais Compósitos. Doutorado em Engenharia de Recursos Naturais pela Universidade Federal do Pará (2016). Pós-Doutorado na área de materiais compósitos pela Universidade Federal do Pará (2016-2017). Atualmente é Professor do Magistério Superior, Classe "A" com a denominação de Adjunto A, Nível 1 do Campus Universitário de Ananindeua da Universidade Federal do Pará. Atua em pesquisa em engenharia de materiais, materiais metálicos ferrosos e não ferrosos e ligas metálicas em geral, materiais polimérico termoplástico e termorrígido, materiais compósito reforçados com fibras naturais, sintéticas e resíduos provenientes da agro-indústria, caracterização de fibras naturais e sintéticas, resíduos de madeira, resíduos industriais e análise de superfície de fratura.

\section{DENILSON BARRETO DA LUZ}

Graduando em Agronomia pela Universidade Federal Rural da Amazônia. É bolsista de Iniciação Científica na área de Agrometeorologia e membro do Grupo de Pesquisa Interações Solo-PlantaAtmosfera na Amazônia (ISPAAm) e do Grupo de Estudos em Nutrição da Palma de Óleo (NUTRIPALMA).

\section{DOUGLAS ALBERTO ROCHA DE CASTRO}

Professor Adjunto com Mestrado do Curso de Engenharia Química do Centro Universitário Luterano de Manaus (CEULM/ULBRA). Experiência como Professor Substituto Auxiliar Nível I do Departamento de Engenharia Química da Universidade Federal do Amazonas (DEQ/FT/UFAM). Aluno de Doutorado (PRODERNA/ITEC/UFPA). Possui Mestrado em Engenharia Química (PPGEQUFPA), graduação em Engenharia Química pela Universidade Federal do Pará (2011). Experiência em Engenharia de Processos de Separação, Termodinâmica de Processos de Separação, Cinética Química e Catálise, Engenharia de Biocombustíveis, Processo de Produção de Biodiesel, Produção de Gasolina Verde, Querosene Verde, Diesel Leve Verde e Diesel Pesado Verde via Craqueamento Térmico-Catalítico de Óleos Vegetais, Óleos Vegetais Residuais, Material Lipídico de Caixa de Gordura, Lodo Ativado Úmido e Rejeitos da Indústria de Processamento de Biodiesel (Sabões), Desacidificação de Frações de Biocombustíveis Verdes (Gasolina Verde, Querosene Verde, Diesel Leve Verde e Diesel Pesado Verde) via Destilação Fracionada, Extração Líquido-Líquido e Adsorção, Engenharia de Processamento e Transformação (Termo-Bioquímica) de Biomassa em Bioetanol e Produto Líquido Orgânico via Pirólise Rápida, Gaseificação, Carbonização Hidrotérmica de Resíduos Agrícolas, Produção de Adsorventes via Carbonização Hidrotérmica de Resíduos Agrícolas, Processos Enzimáticos. Estagiou no Laboratório Nacional Agropecuário - LANAGRO/PA (20082010) e na Unidade Piloto de Produção de Biodiesel (FEQ / ITEC / UFPA) (2010-2011). Tem experiência nas áreas de Engenharia Química, com ênfase em Processos de Produção de Biocombustíveis, além de seu controle de qualidade. E em análises químicas de alimentos de origem animal e vegetal e água.

\section{ELIO FERREIRA DE MORAES JUNIOR}

Licenciado em química pela Universidade Federal do Pará (2015); foi bolsista do Programa Institucional de Iniciação a Docência (PIBID), também colaborou no Laboratório de Controle de Qualidade e Meio Ambiente (LAQCMA) atuando na pesquisa de controle de qualidade de alimentos regionais. Atualmente é aluno do Programa de Pós-Graduação em Engenharia Química da mesma instituição. 


\section{EMANUEL NEGRÃO MACÊDO}

Possui graduação em Engenharia Química pela Universidade Federal do Pará (1993) e doutorado em Engenharia Mecânica pela Universidade Federal do Rio de Janeiro (1998). Atualmente é professor associado III da Universidade Federal do Pará. Tem experiência nas áreas de Engenharia Química e Mecânica, com ênfase em Princípios Variacionais e Métodos Numéricos, atuando principalmente nos seguintes temas: transformada integral, fluidos não-newtonianos, transferência de calor e massa e modelagem e simulação de processos.

\section{ENDRIL PABLO BRASIL DE FREITAS}

Graduado do curso de Licenciatura Plena em Ciências Naturais com Habilitação em Química, pela Universidade do Estado do Pará - UEPA, Campus XIX; Voluntário do Programa Residência Pedagógica - Núcleo Ciências - UEPA/Salvaterra; Experiência em Ensino de Ciências Naturais e Ensino de Química na Educação Básica; Foi Bolsista do Programa Institucional de Iniciação Científica - PIBIC/CNPq com o Projeto de Pesquisa "Caracterização Química do Mel Produzido no Município de Cachoeira do Arari - Ilha de Marajó, Pará" no ano de 2018.

\section{FELIPE SANTOS PIMENTEL}

Possui graduação em Engenharia Química pela Universidade Federal do Espírito Santo (2017) e mestrado em Energia pela Universidade Federal do Espírito Santo (2019). Trabalhou com copirólise de biomassa e resíduo plástico e fluidodinâmica de leito de jorro envolvendo mistura de areia e biomassas.

\section{FRANCINE DUARTE CASTRO}

Bacharel e Mestre em Engenharia Química. Experiência com caracterização de águas e efluentes / tratamento em escala de laboratório, síntese e caracterização de catalisadores e experiência no ensino superior. Atualmente, Francine é doutoranda em Engenharia Ambiental na Universidade de Brescia.

\section{GABRIEL DA SILVA GOMES}

Graduado em Ciência e Tecnologia com enfâse em tecnologia mineral pela Universidade Federal do Pará (2018), atualmente é mestrando em engenharia civil pelo programa de pós-graduação em engenharia civil (PPGEC/UFPA). Fazendo parte dos grupos de pesquisa GTEMA (Grupo de Tratamento e Extração de Minérios e Meio Ambiente, ACGeo (Avanços na Ciência dos Geopolímeros).

\section{GISANDRO REIS DE CARVALHO}

Graduado em Engenharia de Alimentos pela Universidade Estadual Paulista "Júlio de Mesquita Filho" (Unesp), no Instituto de Biociências, Letras e Ciências Exatas (Ibilce) em 2011. Mestrado (2014) e Doutorado (2018) em Engenharia e Ciência de Alimentos, com ênfase em Engenharia de Alimentos, trabalhando com aplicação de ultrassom em processos como desidratação osmótica, hidratação e secagem. Atualmente é pesquisador de Pós-Doutorado da Universidade de São Paulo (USP), na Escola Superior de Agricultura "Luiz de Queiroz" (ESALQ), trabalhando com engenharia de processos na indústria de alimentos, fazendo parte do Grupo de Estudos em Engenharia de Processos $\left(\mathrm{Ge}^{2} \mathrm{P}\right)$, na utilização de tecnologias como ultrassom, vácuo, micro-ondas e plasma ativado no processamento de alimentos.

\section{GUSTAVO HENRIQUE BARROSO DA SILVA}

Possui ensino-medio-segundo-grau pelo Centro Educacional Luiz Simões(2014). Tem experiência na área de Ciência e Tecnologia de Alimentos, com ênfase em Engenharia de Alimentos. 


\section{HAIANNY BEATRIZ SARAIVA LIMA}

Engenheira de Materiais em formação, atualmente voluntária no projeto de pesquisa com ênfase na fabricação de compósitos.

\section{HENRIQUE SENNA}

PhD in Business Administration from the São Paulo University, Brazil (2017). Full Professor at the Minas Gerais Southeastern Federal Institute, Brazil. Master by the Sao Paulo Energy and Nuclear Research Institute, Graduated in Business Administration by the Juiz de Fora Federal University. Industrial Technician by the Minas Gerais Federal University.

\section{HINA DA SILVA FURTADO}

Formada em Licenciatura plena em Química pela Universidade Estadual do Amapá (2012), especialista em Docência do Ensino Superior, pelo Instituto de Ensino Superior do Amapá (2014) e Mestre em Ciências Farmacêuticas pela Universidade Federal do Amapá (2018). Atuo como professora do ensino Médio na Escola Estadual Colégio Amapaense. Linha de pesquisa: Meio Ambiente, contaminação por metais em água, solo e plantas.

\section{IRLON FERREIRA MACIEL}

Professor Adjunto C Nível I na Universidade Federal do Amapá. Orientador de Mestrado e Doutorado no Programa de Pós-Graduação em Ciências Farmacêuticas (PPGCF), Inovação Farmacêutica (PPGIF) e Rede de Biodiversidade e Biotecnologia da Amazônia Legal (BioNorte). Pioneiro entre os Grupos de Pesquisa da Região Norte, no estudo das propriedades Química-Biológica da fibra do casulo do bicho-da-seda (Bombyx mori). Doutorado em Química Orgânica e Biológica pela Universidade de São Paulo - Instituto de Química de São Carlos. Mestre em Ciência e Tecnologia Ambiental, com dissertação na área de Síntese Orgânica pela Universidade Federal da Grande Dourados (UFGD). Licenciado em Química pela Universidade Estadual de Mato Grosso do Sul (UEMS).

\section{IVAN PEDRO ARÊDES SOUSA XAVIER}

Bacharel em Engenharia Química pelo Centro Universitário do Leste de Minas Gerais (2018) e Licenciado em Química pela Faculdade Mozarteum de São Paulo (2019). Atualmente atua como professor de educação básica em Química para o ensino médio.

\section{JACKELINE KERLICE MATA GONÇALVES}

Graduanda em Farmácia pela Faculdade de farmácia da Universidade Federal do Pará, tendo experiência com análises químicas de produtos alimentícios. Integrante do laboratório de Física Aplicada à Farmácia (LAFFA) da UFPA.

\section{JAMYLA SOARES ANÍCIO OLIVEIRA FÉLIX}

Bacharel em Engenharia Química pelo Centro Universitário do Leste de Minas Gerais (2018).

\section{JAVIER TELIS ROMERO}

Técnico em Eletrônica pelo Instituto Tecnologico de Orizaba - México (1979), Graduação em Engenharia Química - Universidad Veracruzana - México (1984), Mestrado e Doutorado em Engenharia de Alimentos (UNICAMP - 1992). Pós-Doutorado - Aplicação de ultrassom em processos alimentícios, Universidad Politecnica de Valencia - España (2007-2008), Professor Titular em Engenharia de Processos (2012). Oferece as disciplinas Graduação: Operações Unitárias I e II, e Sistemas Particulados; Pos-Graduação: Fenômenos de Transporte I, Sistemas Particulados e Reologia. Parecerista de revistas: International Journal of Heat and Mass Transfer e Journal of Food 
Engineering. Trabalha com linhas de pesquisa: Fenômenos de Transporte e Operações Unitárias no processamento de alimentos.

\section{JOÃO MARCOS BATISTA DA ASSUNÇÃO}

Graduado em Ciências Naturais com Habilitação em Química pela Universidade do Estado do Pará (UEPA), Campux XIX. Atuou como professor de Química no Cursinho Popular (UEPA) em 2017 e 2018. Participou como integrante de Iniciação Científica do PIBIC- CNPq de 2018 a 2019. Possui experiência na Área de Química, com ênfase em ensino de Química e de Ciências, atuando principalmente nos seguintes temas: contextualização, experimentação, materiais alternativos e educação ambiental. Trabalha com análises espectrofotométricas de compostos fenólicos totais, flavonoides e análises fisico-químicas.

\section{JOÃO PEDRO DOS REIS LIMA}

Graduando em Farmácia pela Universidade Federal do Pará, com trabalhos desenvolvidos com análises químicas de alimentos. Integrante do laboratório de Física Aplicada à Farmácia (LAFFA) da UFPA.

\section{JOSÉ LUIZ VIEIRA NETO}

Possui Graduação (2004), Mestrado (2007) e Doutorado (2011) em Engenharia Química pela Universidade Federal de Uberlândia - UFU. Atualmente é Professor de Magistério Superior na Universidade Federal do Triângulo Mineiro (UFTM) no curso de Engenharia Química do Instituto de Ciências e Tecnologia e Exatas (ICTE). Tem experiência na área de Engenharia Química com ênfase em Processos de Separação e mistura; escoamento multifásico granular (leito de jorro, leito fixo e leito fluidizado); simulações pela técnica de fluidodinâmica computacional (CFD, DEM), secagem de biomassas (resíduos e frutas), secagem e granulação de fertilizantes, secador rotativo, secadores solares (energia renovável), extração sustentável de óleos essenciais, e ainda, escoamentos em seções anulares.

\section{JOSIVAN DA SILVA COSTA}

Licenciado em Química pela Universidade do Estado do Amapá (2011). Especialista em ensino de química pela Universidade Candido Mendes (2015). Doutorado em Biotecnnologia pela rede Bionorte (Área de concentração: Biotecnologia; Linha de pesquisa: Planejamento Racional de compostos bioativos). Professor Efetivo da rede pública de ensino do Estado do Amapá. Professor temporário da Universidade do Estado do Amapá-UEAP. Atividades realizadas nas áreas ambientais, educacionais, química orgânica, físico-química, sáude e modelagem molecular.

\section{JULIANNE SILVA LALOR}

Possui ensino médio segundo grau pelo colégio impacto. Tem experiência na área de Engenharia de Materiais e Metalúrgica.

\section{KARLA SUELLEN LINO BARBOSA}

Possui graduação em Bacharelado em Ciência e Tecnologia pela Universidade Federal do Pará (2018). 


\section{KÁSSIA GRACIELE DOS SANTOS}

Possui graduação (2006), mestrado (2008) e doutorado (2011) e pós- doutorado (2011-2013) em Eng. Química pela Universidade Federal de Uberlândia - UFU. Atualmente é Professora no curso de Engenharia Química na Universidade Federal do Triângulo Mineiro - UFTM e atua como membro efetivo do Programa Multicêntrico de Pós-Graduação em Química (PMPG-Qui), da Rede Mineira de Química. Tem experiência na área de Engenharia Química, nos temas: leito de jorro, pirólise de biomassa, fluidodinâmica computacional (CFD, CFD-DEM), granulação de fertilizantes; extração sustentável de óleos essenciais, escoamento multifásico granular, clarificação de lecitina de soja, energias renováveis. Ganhadora do Prêmio Capes de Tese de Doutorado 2012, da área de Engenharias II.

\section{KÁSSIA GRACIELE DOS SANTOS}

Possui graduação (2006), mestrado (2008) e doutorado (2011) e pós-doutorado (2011-2013) em Eng. Química pela Universidade Federal de Uberlândia - UFU. Atualmente é Professora no curso de Engenharia Química na Universidade Federal do Triângulo Mineiro - UFTM e membro efetivo dos Programas Multicêntrico de Pós-Graduação em Química (PMPG-Qui) e PMPIT. Tem experiência na área de Engenharia Química, nos seguintes temas: secagem de resíduos, leito de jorro, pirólise de biomassa, fluidodinâmica computacional (CFD, CFD-DEM), granulação de fertilizantes; extração sustentável de óleos essenciais, escoamento multifásico granular, clarificação de lecitina de soja, energias renováveis. Ganhadora do Prêmio Capes de Tese de Doutorado 2012, da área de Engenharias II.

\section{KELLY DAS GRAÇAS FERNANDES DANTAS}

Possui graduação em Bacharelado e Licenciatura Plena em Química pela Universidade Federal de Viçosa (1999), mestrado em Química pela Universidade Estadual Paulista Júlio de Mesquita Filho (2001), doutorado em Ciências (área: Química Analítica) pela Universidade Federal de São Carlos (2005) e pós-doutorado em Química Analítica pela Universidade Federal de São Carlos (2006). Foi coordenadora do PIBID Química/UFPA. Atualmente é professora associada- Nível 3 da Universidade Federal do Pará, coordenadora acadêmica do curso de Licenciatura em Química e membro do Comitê assessor de Pesquisa PIBIC da UFPA.Tem experiência na área de Química Analítica, com ênfase em técnicas espectroanalíticas, atuando principalmente nas seguintes técnicas: preparo de amostras, FAAS, GFAAS, ICP OES, MIP-OES, HPLC-ICP-MS e HPLC-GFAAS.

\section{KEYLLA CASTRO FERREIRA}

Mestre em Engenharia Química pela Universidade Federal do Pará (2014). Possui graduação em Engenharia Química pela Universidade Federal do Pará (2011). Curso-técnico-profissionalizante em Mineração pelo Instituto Federal de Educação, Ciência e Tecnologia do Pará (2006). Área de Atuação Engenharia Química, Reaproveitamento de Resíduos Inorgânicos, Caracterização Química e Física de Materiais, Desenvolvimentos de Processos Químicos, Operações Unitárias e Química Geral.

\section{KLEBER BITTENCOURT OLIVEIRA}

Possui graduação em Engenharia Química (2006), Especialização em Tecnologia Mineral (2008), Mestrado em Engenharia Química (2008) e Doutorado em Engenharia de Recursos Naturais da Amazônia, ambos pela Universidade Federal do Pará. Atualmente é professor Adjunto do curso de Engenharia Química na Universidade Federal do Pará e professor no Programa de Pós-Graduação em Engenharia de Processos - PPGEP/ITEC/UFPA (www.ppgep.propesp.ufpa.br). Tem experiência em processos de separação com ênfase na aplicação de membranas em processos hidrometalúrgicos, no tratamento de águas, efluentes e operações de "downstream" em processos bioquímicos. 


\section{LAURO HENRIQUE HAMOY GUERREIRO}

Estudante de Engenharia Química pela Universidade Federal do Pará. Cursando o ultimo semestre, fui durante 2 anos aluno de iniciação científica (PIBIC) pelo Laboratório de Processos e Separações Térmicas. Estagiário da empresa Sampaio \& Moraes- Indústria de Bebidas, com ênfase em Refrigerantes, estagiando no setor de qualidade com ênfase em gestão, controle de perdas e melhoramento do processo industrial com criações de procedimentos que amarrem o processo produtivo.

\section{LEILIANE DO SOCORRO SODRÉ DE SOUZA}

Possui graduação em Engenharia Química pela Universidade Federal do Pará (2010) e mestrado em Engenharia Química pela Universidade Federal do Pará (2013). Atualmente é doutoranda no Programa de pós-graduação em Engenharia de Recursos Naturais da Amazônia e professora assistente da Universidade Federal do Amazonas. Tem experiência na área de Tecnologia de Óleos e Gorduras, Secagem de alimentos e Processos Fermentativos e Aproveitamento de Resíduos Lignocelulósicos.

\section{LORENA FERREIRA ALVES}

Bacharel em Engenharia Química pelo Centro Universitário do Leste de Minas Gerais (2018).

\section{MARCELO LINARDI}

Doutor em Engenharia Química - Universitat Karlsruhe, Alemanha Instituto de Pesquisas Energéticas e Nucleares - IPEN/USP. IPEN Researcher Emeritus 2019. Graduated in Chemical Engineering from the Campinas State University (1983), Master in Nuclear Sciences from the Aeronautics Technological Institute (1987), PhD in Chemical Engineering - Karlsruhe University (1992) and Postdoc from the Darmstadt University, Germany in 1998.

\section{MÁRCIA LÍDIA BASTOS DA SILVA}

Graduanda em licenciatura plena em ciências naturais com habilitação em Química pela Universidade do Estado do Pará.

\section{MARCIO AUGUSTO RIBEIRO SANCHES}

Possui curso Técnico / profissionalizante em Segurança do Trabalho pelo Instituto Federal Goiano IF Goiano (2017). Graduação em Engenharia de Alimentos pela Universidade Federal de Mato Gosso - UFMT (2017). Atualmente é Mestrando pelo Programa de Pós-graduação em Engenharia e Ciência de Alimentos na Universidade Estadual Paulista Júlio de Mesquita Filho - UNESP. Atua na área de engenharia de processos para a indústria de alimentos, desenvolvendo pesquisas com aplicação de ultrassom sobre o processamento de alimentos, com foco na área de carnes.

\section{MARIA JANES DE OLIVEIRA SANTOS}

Possui graduação em Licenciatura Plena em Química, pelo Instituto Federal de Educação Ciência e Tecnologia do Pará - IFPA (2007) e mestrado em QUÍMICA pela Universidade Federal de RoraimaUFRR (2014), na linha de pesquisa da QUÍMICA ANALÍTICA, neste ano (2019) concluindo uma especialização em METODOLOGIA DA CIÊNCIA NA NATUREZA pela Faculdade ESTÁCIO BELÉM, para fornecer maior conhecimento, capacitação e aprimoramento no ensino fundamental. Trabalho como professora no ensino médio na área especifica de QUÍMICA. 


\section{MARIO LUCIVALDO BARRETO DE JESUS}

Possui Curso técnico em Química (CEPC) e graduação em Gestão Ambiental (Estácio). Atualmente é discente de mestrando do Programa Ciência e Meio Ambiente (Universidade Federal do Pará - UFPA) e servidor Da UFPA atuando no cargo de Técnico em Química.

\section{MARIA JÚLIA NEVES MARTINS}

Graduada em Engenharia Química pelo Centro Universitário da Fundação Educacional de Barretos (UNIFEB) em 2015. Trabalhou como Analista de Laboratório Industrial na área de tratamento de caldos e açúcar. Possui Mestrado em Engenharia e Ciência de Alimentos pelo Instituto de Biociências, Letras e Ciências Exatas (Ibilce), trabalhando com desidratação osmótica de gengibre assistida por ultrassom. Atualmente é doutoranda no mesmo instituto e linha de pesquisa.

\section{MAYARA GALVÃO MARTINS}

Possui graduação em Engenharia de Alimentos pela Universidade Federal do Pará (2013), Mestrado em Ciência e Tecnologia de Alimentos pela Universidade Federal do Pará (2015). Atuou nas áreas de desenvolvimento e otimização de processos em produtos de origem vegetal (tucupi, cacau, amido) e animal (pescado), como extração, fermentação, torração, secagem, salga e desidratação osmótica. Atualmente, está concluindo seu doutorado em Ciência e Tecnologia de Alimentos pela Universidade Federal do pará (2016-2019).

\section{MAYCON RUAN PINHEIRO DE OLIVEIRA}

Graduado em Ciência e Tecnologia com ênfase em Tecnologia Mineral pela Universidade Federal do Pará (2019). Atualmente é estudante do curso Técnico em Mineração (IFPA).

\section{NATÁLIA PAZIN ALMEIDA}

Engenheira Química pela Universidade Federal do Triângulo Mineiro (UFTM- Uberaba) e mestranda em Engenharia Química pela Universidade Federal de Uberlândia. Possui experiência em processos de separação e fluidodinâmica (experimental e simulação computacional) de equipamentos envolvendo escoamento granular de sólidos, tais como: tambor rotativo, leitos fluidizado e de jorro.

\section{RAFAELA OLIVEIRA PINHEIRO}

Possui graduação em Gestão Pública pelo Instituto Federal de Educação, Ciência e Tecnologia do Pará (2015). Mestranda do Programa de Ciência e Meio Ambiente da Universidade federal do Pará. Atualmente é tecnico de laboratório da Universidade Federal do Pará. Atua no Laboratório de Engenharia Química, com ênfase em extração de produtos naturais.

\section{RAISSA SAYUMY KATAKI FONSECA}

Graduação em Engenharia de Alimentos.

\section{RAYANA SILVA CRAVEIRO}

Graduanda em Ciências Naturais com Habilitação em Química, pela Universidade do Estado do Pará, UEPA, Campus XIX; Foi Bolsista do Programa Residência Pedagógica- Núcleo Ciências - UEPA/ Salvaterra (2018- 2020); Voluntária do Programa Institucional de Bolsas de Iniciação Científica PIBIC-CNPq com o projeto de Pesquisa "Caracterização química do mel produzido em Cachoeira do Arari- Ilha de Marajó, Pará" no ano de 2018; Possui experiência nas áreas de pesquisa, ensino de ciências naturais na Educação Básica e em organização de eventos científicos. 


\section{ROBERTO MESSIAS BEZERRA}

Graduação em Licenciatura em Química pela Universidade Federal do Mato Grosso do Sul, Campo Grande, no período de 1989 à 1993; Realizou mestrado em (Físico-Química) pela Universidade de São Paulo - USP/São Carlos no período de 1996 a 1999); Realizou o doutorado em ciências exata e da terra pela Escola de Engenharia de São Carlos - Universidade de São Paulo, USP/São Carlos no período de 2002 à 2005. Atua como docente da Universidade Federal do Amapá, UNIFAP, e participou da criação do Curso de Química da Universidade do Estado do Amapá, e concomitante com a criação da própria Universidade, UEAP, em 2006, onde atuou como docente até o ano de 2009.

\section{RODRIGO RODRIGUES EVANGELISTA}

Graduado em Engenharia de Alimentos pelo Centro Universitário da Fundação Educacional de Barretos - UNIFEB em 2017. Atuou como Analista de PCP Jr na empresa JBS Foods - Seara Alimentos, com experiência na área de programação de produção, programação de insumos, programação de embarques para atendimento do Mercado Externo e gerenciamento de indicadores de performance. Atualmente é Mestrando no Programa de Pós-Graduação em Engenharia e Ciência de Alimentos pelo Instituto de Biociências, Letras e Ciências Exatas (Ibilce), atuando na área de Engenharia de Processos para Indústria de Alimentos, como determinação do comportamento reológico e propriedades físicas dos alimentos.

\section{ROMERO MOREIRA DE OLIVEIRA}

Possui graduação em Engenharia Química pela Universidade Federal do Pará (2011), mestrado em Engenharia Química pela Universidade Federal do Pará (2013) e doutorado em Engenharia de Recursos Naturais da Amazônia PRODERNA/UFPA (2019). Tem experiência na área de Engenharia Química, com ênfase em uso e transformação de recursos naturais, catálise, produção de biocombustíveis via transesterificação e craqueamento termo catalítico, e fiscalização de produtos químicos controlados pelo exercito.

\section{ROQUE MACHADO DE SENNA}

PhD in Sciences, with emphasis on Proton Exchanger Membrane Fuel Cell Systems (PEM), University of São Paulo (2012), graduated in Electrical Engineering, Juiz de Fora Federal University(1980), graduated in Mechanical Technology, by the Bahia Federal Institute (2006), Electrotechnical Technician by the Juiz de Fora Federal University. PhD (adjunct) Professor at the São Paulo Federal University, former Research Collaborator at the São Paulo Energy and Nuclear Research Institute, teaches the Subjects: Automation and Instrumentation Principles; Electrotechnology Applied to Chemical Engineering; Industrial Systems, with research focused on Technology for Fuel Cell Electric Power Generation, as well asther Technologies for Electric Power Generation by Renewable Fuels. His research has addressed Fuel Cell Systems and Accumulators, as well as Technical and Economic Studies in Cogeneration Systems - Sugarcane Sector.

\section{SAMARA DE PAULA PINHEIRO MENEZES MARQUES}

Licenciada Plena em Ciências com habilitação em Química, pela Universidade Federal do Pará (UFPA) (2011), Mestre em Química pela Universidade Federal do Pará (2017) e Doutoranda no Programa de Pós Graduação em Engenharia de Recursos Naturais da Amazônia (PRODERNA). Experiência na área de Química Analítica e na área de controle de qualidade de alimentos, com ênfase em análises físico-químicas. Servidora na Universidade Federal do Pará, no cargo Químico, atuando no Laboratório de Espectrofotometria da Engenharia Química. 


\section{SILVANE GONÇALVES E GONÇALVES}

Bolsista Capes no Programa de Doutorado em Engenharia de Recursos Naturais da Amazônia na Universidade Federal do Pará. Graduada e Mestra em Engenharia Química pela Universidade Federal do Pará. Possuo práticas laboratoriais na área de estudo do potencial oleífero e das propriedades físico-químico de oleaginosas amazônicas e na área de Reologia de fluidos newtonianos e não newtonianos.

\section{SILVIO BISPO DO VALE}

Possui graduação em Engenharia Química pela Universidade Federal do Pará (1991), graduação em Licenciatura Plena em Ciência - Habilidade em Química pela Universidade Federal do Pará (1994), mestrado em Engenharia Elétrica pela Universidade Federal do Pará (2000) e doutorado em Engenharia Elétrica pela Universidade Federal do Pará (2006). Atualmente é Professor Associado III do Curso de Bacharelado em Ciência e Tecnologia da Universidade Federal do Pará. Tem experiência na área de Engenharia de Minas e Meio Ambiente, Engenharia Industrial e Engenharia Elétrica, com ênfase em Geração da Energia Elétrica, atuando principalmente nos seguintes temas: geração de energia, sistema solar fotovoltaico, sistema híbrido de geração, sistema eólico e Tratamento de Minérios.

\section{TAISA SHIMOSAKAI DE LIRA}

Possui Graduação em Engenharia Química pela Universidade Federal de Uberlândia (2003), Mestrado em Engenharia Química pela Universidade Federal de Uberlândia (2005) e Doutorado em Engenharia Química pela Universidade Federal de Uberlândia (2009). É Professora Adjunto do Departamento de Engenharias e Tecnologia e Professora Permanente do Programa de Pósgraduação em Energia, ambos da Universidade Federal do Espírito Santo. Tem experiência na área de Engenharia Química, com ênfase em Modelagem, Simulação e Otimização de Processos, atuando principalmente com pirólise de biomassa.

\section{JAVIER TELIS ROMERO}

Técnico em Eletrônica pelo Instituto Tecnologico de Orizaba - México (1979), Graduação em Engenharia Química - Universidad Veracruzana - México (1984), Mestrado e Doutorado em Engenharia de Alimentos (UNICAMP - 1992). Pós-Doutorado - Aplicação de ultrassom em processos alimentícios, Universidad Politecnica de Valencia - Espanha (2007-2008), Professor Titular em Engenharia de Processos (2012). Oferece as disciplinas Graduação: Operações Unitárias I e II, e Sistemas Particulados; Pos-Graduação: Fenômenos de Transporte I, Sistemas Particulados e Reologia. Parecerista de revistas: International Journal of Heat and Mass Transfer e Journal of Food Engineering. Trabalha com linhas de pesquisa: Fenômenos de Transporte e Operações Unitárias no processamento de alimentos.

\section{THAIS SANTOS}

University student in Chemical Engineering. Her scientific studies focus on the Fuel Cells and Hydrogen area, with her works part published at COBEC-IC-2017, and in the book Impacts of Technologies on Chemical Engineering 3 chapter (21).

\section{THAIS SIQUEIRA TOMASELLO}

Graduada em Engenharia de Alimentos pela Universidade Estadual Paulista "Júlio de Mesquita Filho", no Instituto de Biociências, Letras e Ciências Exatas (Ibilce) em 2019. Atualmente trabalhando na empresa Biosev. 


\section{TIAGO CARREGARI POLACHINI}

Doutor em Engenharia e Ciência de Alimentos pela Universidade Estadual Paulista "Júlio de Mesquita Filho" (UNESP/IBILCE), subárea de Engenharia de Processos para Indústria Alimentícia, com dupla titulação em Ciencia, Tecnología y Gestión Alimentaria pela Universitat Politècnica de València (UPV) (Valencia/Espanha) no Grupo de Análisis y Simulación de Procesos Agroalimentarios (ASPA). Graduação e Mestrado em Engenharia de Alimentos pela Universidade Estadual Paulista "Júlio de Mesquita Filho" (UNESP/IBIILCE). Experiência na determinação e modelagem de propriedades físicas, reologia, fluidodinâmica, isotermas de sorção e secagem de produtos da agroindústria. Experiência no desenvolvimento e avaliação de processos agroalimentares assistidos por ultrassom de alta intensidade.

\section{THAIS SIQUEIRA TOMASELLO}

Graduada em Engenharia de Alimentos pela Universidade Estadual Paulista "Júlio de Mesquita Filho", no Instituto de Biociências, Letras e Ciências Exatas (Ibilce) em 2019. Atualmente trabalhando na empresa Biosev.

\section{WALISSON GUILHERMITTE RODRIGUES}

Graduado em Engenharia de Alimentos pela Universidade Estadual Paulista "Júlio de Mesquita Filho", no Instituto de Biociências, Letras e Ciências Exatas (Ibilce) em 2018. Atualmente trabalhando na empresa JBS Foods - Seara Alimentos na área de controle e garantia de qualidade.

\section{WASSIM RAJA EL BANNA}

Possui graduação pela Universidade Federal do Pará (2009). Tem experiência na área de Engenharia Mecânica, com ênfase em Processos de Fabricação. Mestrado em Engenharia Mecânica pela Universidade Federal do Pará (2012) na área de Concentração de Materiais e Processos de Fabricação, sub-área de Materiais Compósitos. Doutorado pelo Programa de Pós-Graduação em Engenharia de Recursos Naturais da Amazônia (PRODERNA) pela Universidade Federal do Pará (2017). Atua em pesquisa com materiais polimérico termoplástico e termorrígido, materiais compósito reforçados com fibras naturais, caracterização de fibras naturais, resíduos de madeira, resíduos industriais e análise de superfície de fratura.

\section{WILSON GUIMARÃES SARAIVA}

Graduando em Ciência e Tecnologia com ênfase em Tecnologia Mineral pela Universidade Federal do Pará - UFPA. MBA em Gestão Estratégica pela Faculdade Estácio de Sá (2014) Tecnólogo em Rede de Computadores pela Escola Superior da Amazõnia - ESAMAZ (2012).

\section{YASMIN MARTINS DOS SANTOS LOPES}

Graduada em Tecnologia de Alimentos pela Universidade do Estado do Pará, Campus XIX, Salvaterra, Marajó- Pará. Tem experiência na área de Ciências e Tecnologia de Alimentos e análises laboratoriais com ênfase em processamento em análises de alimentos e controle de qualidade de alimentos. Atualmente faz parte de pesquisas na área de produtos de origem animal: Leite Bubalino e aspectos de sua qualidade. Atuou como monitora no Laboratório de Tecnologia de Alimentos e desenvolve pesquisas na área de bebidas. 


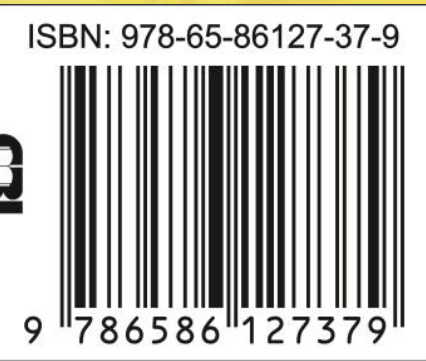

